This dissertation has been $\quad 63-4896$ microfilmed exactly as received

KIM, Richard Chong Chin, 1923JEHOVAH'S WITNESSES AND THE SUPREME COURT. AN EXAMINATION OF THE CASES BROUGHT BEFORE THE UNITED STATES SUPREME COURT INVOLVING THE RIGHTS CLAIMED BY JEHOVAH'S WITNESSES, FROM 1938 TO 1960.

University Microfilms, Inc., Ann Arbor, Michigan

KIM, Richard Chong Chin, 1923- 63-4896

The University of Oklahoma, Ph.D., 1963 Political Science, general

University Microfilms, Inc., Ann Arbor, Michigan 
THE UNIVERSITY OF OKLAHOMA

GRADUATE COLLEGE

JEHOVAH'S WITNESSES AND THE SUPREME COURT

An Examination of the Cases Brought before the United States Supreme Court involving the Rights Claimed by Jehovah's Witnesses, from 1938 to 1960.

A DISSERTATION

SUBMITTED TO THE GRADUATE FACULTY

in partial fulfillment of the requirements for the

degree of

DOCTOR OF PHILOSOPHY

BY

RICHARD CHONG CHIN KIM

Norman, Oklahoma

1963 
JEHOVAH'S WITNESSES AND THE SUPREME COURT

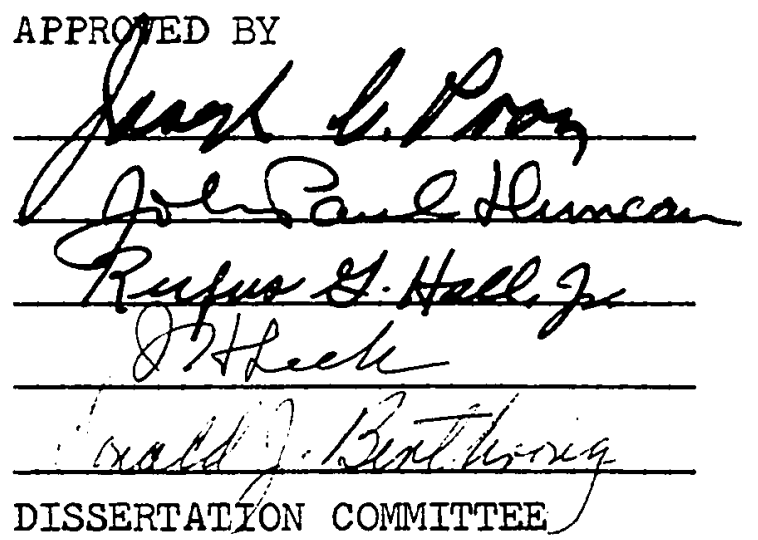


Acknowledgment is hereby made to $\mathrm{Dr}$. Joseph C. Pray whose assistance was rendered under trying conditions; and to my wife for her timeless encouragement and her relentless labor over the typewriter. 
TABIE OF CONTENTS

PAGE

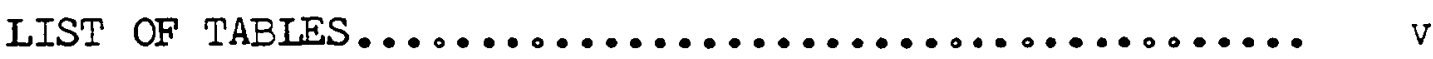

PREFACE............................. vi

PART I INTRODUCTION

CHAPTER

I. JEHOVAH'S WITNESSES: WHENCE, WHO, WHY....... I

II. BY WAY OF DUE PROCESS................. 31

PART II THE COURT, THE CONSTITUTION, AND THE CULT

III. SOLICITATION AND STATE ORDINANCES........ 57

IV. PERMITS, PARKS, AND PARADES.............. 81

V. SOUND DEVICES AND "FIGHTING WORDS"......... 102

VI. LIFE, LIBERTY, AND LICENSE TAXES........... 122

VII. "THOU SHALT NOT GIVE ALIEGIANCE"........... 190

VIII. PEDDLING VS. PRIVATE PROPERTY............. 245

IX. CONSCRIPTION AND CONSCIENCE............... 260

PART III CONCLUSION

X. IEGALITY AND IEGACY.................... 354

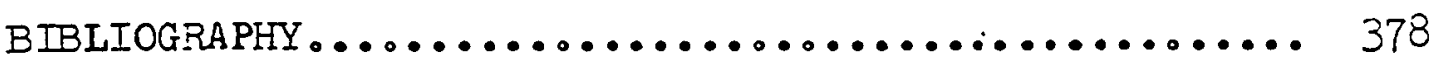




\section{LIST OF TABIES}

Table

Page

1. List of Cases involving Jehovah's Witnesses according to Chapters.................. 374

2. Statutory Definition of Minister.......... 376

3. Statutory Provision Relating to Conscientious objection.. 


\section{PREFACE}

The role of the Jehovah's Witnesses in American Constitutional law is immeasurable. So far, no comprehensive study of their complete activity has appeared in print. Not unlike the others which have appeared, this examination does not purport to be a comprehensive coverage of the activity of this unpopular but persistent sect. But it does cover all the Jehovah's Witnesses cases brought before the highest court in the nation within a twenty-two year period. While the study is restricted only to those cases brought before the supreme Court of the United States, the task, even on such a confined level is admittedly a monumental undertaking. To examine the decisions and to quote from them are simple enough, for the United States Reports are neatly arranged on most library shelves, and the opinions of the justices are usually quite readable. But such a restricted endeavor is hardly profitable to the writer or the reader. Rather than being so restricted, the desire for profit has necessitated some interpretation in this study.

Undoubtedly, before the cases were brought before the high tribunal, much activity -- social, political, and legal -occurred on the local level. All these occurrences, for obvious reasons, have not been recorded in the study, except in those cases where the knowledge of related incidents has been deemed indispensable to a reasonable understanding of the cases. Too, the examination of localized activities has been conditioned 
by the moment and consequence of public reaction, as in the flag salute and license tax cases. No one can ever know all that these cases entailed. The number of people involved, the amount of money spent, the numerous heart-aches and even the "bashed heads," whatever their number and value, are now strangely removed by time, incomplete records, and the tricks of memory. Appreciation is to a large degree, a result of experience; and this examination which is the result of a lengthy experience of research and study, has made the writer more appreclative of some of the things to which he once claimed fairly adequate knowledge. It is personally gratifying to note that the Supreme Court is composed of MEN whose responsibility is carefully exercised in order to assure the citizenry of the best possible interpretation of the constitution. Whether the Court is "right" or "wrong" in its interpretation is immaterial to the argument. It is enough that the EFFORT to be right is at an optimum.

Because this study originally called for a theoretical examination of religious freedom, it is even more gratifying to note that the investigation of selected court cases reveals at least one general theoretical conclusion. That is, in this country neither the majority nor the minority is a recipient of special favors -- at least from the supreme court -- on its own merits. The law is made applicable to all on an equal plane. To be sure, discrimination exists, and will continue to exist as long as imperfect men make their abode in an imperfect 
society. But in behalf of the men of the supreme court, it is acknowledged that the awareness of this discrimination has led them to a responsible exercise of their functions. To the court, whether the litigants are Jehovah's Witnesses or not, is unimportant, but it is of great consequence that the rights accorded to individuals by the constitution be carefully protected from undue infringement. 


\title{
JEHOVAH'S WITNESSES AND THE SUPRENE COURT
}

\author{
PART I \\ INTRODUCTION
}

CHAPTER I

JEHOVAY'S WITNESSES, WHENCE, WHO, WHY

In the development of American constitutional law, the highest repository of judicial decisions, the supreme Court of the United States, has been plagued time and again by a relatively small religious sect known as the Jehovah's Witnesses. No religious group in the country, whatever its size or belief, has pressed the high tribunal for so many decisions involving various constitutional questions as have these "most vehement and spectacular, and also the most vigorous propagandists of 211 [sects]."I Without precedent, "in recent years they have taken the time of the courts more than any other religious group." 2 The activity of this enthusiastic religious group has not only been extensive, it has been of great import to the definition of fundamental liberties. As early as 1942, a brief but cursory study revealed that in the years between 1938 and 1942, "a smal:

lElmer T. Clark, The Small Sects in America (New York: Abingdon Press, 1937), p. 45 .

${ }^{2}$ Anson Phelps Stokes, Church and State in the United States (New York: Harper and Brothers, 1950), III, p. 546. 
2

religious sect or society known as Jehovah's Witnesses has served as the guinea pig for all the important cases."3 That this unconventional religious order served to test ali the important cases before the courts may be questionable, but It is true that in a twenty-year period between 1938 and 1958, "the Witnesses have won forty-four of fifty-five cases in the United States Supreme court." 4 .

The Jehovah's Witnesses are not considered to be in the traditional American religious mainstream. While precise definition is not forthcoming, most historians and sociologists, as well as laymen, have evolved certain ways of classifying American religious groups. Often these sects and cults are called the "third force" of the American mainstream and

the more isolated, intransigent, withorawn, the less exposed ano eroded a group has been, no matter what its size and influence, the less it has come to be regarded as a normative religious expression in

3ictor W. Rotnem, and F.G. Folsom Jr., "Recent Restrictions Upon Religious Liberty," American Polltical Science Review, XXXVI (December, 1942), p. 1055. Hereaf'ter cited as A.P.S.R. Done under the auspicies of the United States Department of Justice, this is probably the best short treatment of the subject up until that time. The study is well done and carefully documented. The brevity of the article seems to be its own indictment inasmuch as the principles and doctrines contained therein are unjustifiably abbreviated.

${ }^{4}$ Clement E. Vose, "Iitigation as a Form of Pressure Group Activity, "The Annals of the American Academy of Political and Social Sciences, CIX (September, 1958), p. 22. Hereafter cited as Annals. 
America. 5

The origin of the modern-day group known as the Jehovah's Witnesses can be traced back to its founder, Charles Taze Russell, who in 1874 "broke" with the calvinistic background under which he had been brought up. It was in that year he "discovered" the "truths" of Christ's return. 6 Five years after "Pastor" Russell's inspiration, in 1879, the Watchtower magazine first went to press and its publication to date has been consistently on the increase. The Watchtower is still the official journal of the Jehovah's Witnesses and is their propaganda instrument. Until 1931, when the name Jehovah's Witnesses was formally adopted, the followers of Russell were called by various names, the most common being "Russelites."

Not unlike the various Christian denominations, the Jehovah's Witnesses are quick in pointing out that their foundation is not dependent upon man, neither is it based solely on the "discoveries" of Charles Taze Russell or anyone

SMarty E. Marion, "Sects and Cults," Annals, CxxxII (November, 1960), p. 128. For more general but pertinent works on American religious life, see: Loren P. Beth, "Toward a Modern American Theory of Church-State Relationships," Political Science Quarterly, IXX (December, 1955), pp. 573-597; William Lee MIIler, "Religion and the Amerlcan Way of Life," Religion and the Free Society (New York: Fund for the Repubilic publication, 1958), pp. 3-20; and by far the most definitive and most informative in this general area, Will Herberg, Protestant Catholic Jew: An Essay in American Religious Sociology (New York: Doubleda y and Co., 1955).

6Royston Pike, Jehovah's Witnesses: Who They Are, What They Teach, What They Do (New York: Philosophical Library, 1954), ?. 10 . 
4

else." "Jehovah God is the Founder and Organizer of his witnesses on earth. The first witness was Abel."? From Abel, the witnesses trace the development of their sect through Enoch, Noah, Abraham, Moses and all the way to John the Baptist -- Indeed to Christ Jesus himself who was the highest witness. Their purpose in witnessing is to make known to the multitudes the message of God. According to their brand of interpretation, the message hinges mainly on the impending doom of the forces of evil to be wrought by the forces of good in the personage of God himself. The urgency of their whole purpose -- unquestionably a great cause for their civic disobedience and court fights -- is contingent on the belief that this doom is imminent.

The Jehovah's Witnesses do not technically constitute a church; they have no specially ordained clergymen. They are in some respects similar to the Salvation Army, although the Salvation Army is considered to be a denomination while the Witnesses are not. "Jehovah's Witnesses are Christians, a people not identified with any sect or denomination." $91-$ though they are an organized body, nationally as well as internationally, "they do not keep a membership roll, nor do

7Vergilius Ferm (ed.), Religion in the Twentieth Century (New York: Philosophical Library, 1948), p. 381.

${ }^{8}$ Stokes, Church and state, p. 541.

9 Yearbook of American Churches, 1943, p. 41. 
5

they compile any census regarding attendance at their meeting places. . ."10 According to their own statement of beliefs,

\begin{abstract}
From man's beginning there have been at all times some of the Jehovah's Witnesses on earth, adhering to the Bible principle of separateness from all parts of the world organization of men. In modern times Jehovah's Witnesses are primitive Christians, recognizing and teaching the Bible as God's word of truth, believing it and following its commandments, which accounts for their neutrality toward any nationalistic interests. II
\end{abstract}

Charles Taze Russell, under whose direction the Jehovah's Witnesses sect found birth and life, was born in Allegheny, Pennsylvania. His parents, Joseph L. and Eliza Russell, were of Scottish-Irish origin. Early in his youth, young Charles became active in the Congregational church and became interested in the Young Men's Christian Association. His mother died when he was nine, and a few years thereafter Russell "began to be shaken in faith regarding many longaccepted doctrines." 12

The contribution of Russell to the growth of the Witnesses is immeasurable. It was he who outlined the basio doctrines of their present-day beliefs. His numerous works sold millions of copies, and his tracts and pamphlets became the cornerstone for the theology -- if it can be called that -- of

$10_{\text {Ibid. }}$

11Yearbook of American Churches, 1960, p. 57. 12 Pike, Jehovah's Witnesses, p. 10. 
the Jehovah's Witnesses. As a preacher his fame covered the earth. He was selected as pastor by two thousand congregations in the United States, Canada, Britain and Europe.

His followers hailed Russell as the greatest and most successful preacher of the Gospel in his generation: indeed, in their enthusiastic admiration they ranked him with St. Paul, St. John, Arius, Waldo, Wycliff, and Martin Luther.13

Many of them believed, as did Russell himself that he was the fulfillment of the scripture, "faithful and wise servant,"I4 and the authorized "faithful and true witness"15 who was the true messenger of this the last epoch in God's plan for mankind. 16

Because the importance of the work of this unusual sect is largely dependent upon printed matter, Russell's contribution to the establishment of a publishing enterprise is no less significant. Two years after the launching of the first Watchtower magazine in 1879, there was the formation of Zion's Watchtower Traci Society, located in Allegheny, Pennsylvania, with Russell as its President. This same chartered non-profit-making corporation took the style of the watchtower Bible and Tract society in 1896, which has continued to this

\footnotetext{
13 Ibid., p. 14.

It Matthew, $24: 45$.

15evelation, 3:14.

16 Pike, Jehovah's Witnesses, p. 14.
} 
day in its form.

When Charles Taze Russell died in 1916, the presidency of the Society passed on to Joseph Franklin Rutherford, better-known as "Judge" Rutherford. The Judge was born in Booneville, Missouri in 1869. According to his critics, he was only for a few days a judge on circuit in Missouri for which he gained the life-long honor of being called "Judge."I7 As a practicing attorney in the days when lawyers were somewhat scarce, he became the leading legal spokesman for the Society. It was in this capacity that he gained fame and popularity with the fold, a distinction which he enjoyed nationally upon inheriting Russell's mantle after the latter's death. Although the time and term of his actual "conversion experience" is hazy, it is thought that he was an active participant for the cause by the early 1900's. When Russell died, Rutherford, although not considered to be the heir apparent by many members of the Society, was elected as the second President of the Watchtower Bible and Tract Society.

Joseph Franklin Rutherford was warmly welcomed in his new capacity as manager of the society's affairs by the majority of those associated with the organization at that time. But from the outset it became apparent that a few, especially at headquarters resented him. Some of these thought they should succeed Russeli and considered themselves better qualified for the position of President. I8

\section{Ibid., p. 19.}

${ }^{18}$ A.H. Macmilian, Faith on the March (Englewood Cliffs: Prentice Hali Inc., 1957), pp. 71-72. 
8

For those who distrusted his divine authority to wear Russell's mantle of leadership, the trial of Rutherford and seven of his colleagues for the violation of the Espionage Act must have offered some comfort. These men were convicted on the charges of conspiring to obstruct recruiting and enlistment during the war, and in 1918 began their jail sentences. Although the sentences were much longer, the Judge served only a nine-month jail term. If the rank and file distrusted Rutherford's divine right to rule, this encounter with the civil authorities, assured them of an act of grace. While in prison he conducted religious meetings, visited fellow prisoners, and wrote weekly letters to the Watchtower. His "martyrdom" was thus consummated via these outward activities which must have been clear "evidence" to the unbelievers.

In at least two important respects, Rutherford differed from his predecessor. He was more versatile and colorful in his social relations, and his publications far exceeded that of his earlier counterpart. Thus in volce and in pen, the disciple outdid the teacher.

Rutherford maintained and steadily improved his position as the Society's arch-propagandist with both voice and pen. A year or two before his death [in 1942] he claimed that he had written ninety-nine books and pamphlets in the preceding twenty years, and he wrote several more before he died. His books were published in seventy-eight languages, and the number of copies distributed exceeded three-hundred millions.19

${ }^{19}$ P1ke, Jehovah's Witnesses, p. 21. 
Compared with Charles 9 = Russell, "J.F. Rutherford's background was totally different. . . he has no youthful life." 20 By this it is meant that he went to work at an early age. Presumably at 16 , he was practicing law. In enthusiasm, Rutherford surpasses his predecessor. In legal a:guments, which he engaged in quite frequently, he was never inhibited, and was quick to invoke the Deity.

In one case the victorious counsel was one Rutherford, a tall rangy man with a heavy mane of hair, a light tan cutaway suit, wing collar, flowing tie, and a massive gold watch chain. His voice was loud and booming. McReynolds, who was given to sharp encounters with lawyers, interrupted Rutherford, 'Instead of applying for a permit, which seems to me a reasonable requirement, this lady defied the law. Tell me, why did she do it?'

Rutherford's answer disclosed the fanatic zeal of this sect. Pointing with his finger to the sky, he fairly bellowed, 'this lady did not get a permit because Jehovah God told her not to. ${ }^{21}$

It was Rutherford's belief that the earthly government should be under the control of the spiritually select. Thus he wrote, "what form of government will then control the people of the earth? That government will be a pure theocracy." 22 Although at times, this doctrine may seem to support revolution, the Judge denied this motive. It may have been naiveté on his

${ }^{20}$ Macmillan, Faith on the March, p. 72.

2lwilliam 0. Douglas, An Almanac of Liberty (New York: Doubleday and Co., 1954), p. 150 .

22 Joseph F. Rutherford, Government (Brooklyn: Watchtower Bible and Tract Society, 1928), p. 247 . 
10

part, but it was more likely unconcern for philosophical problems which led him to say;

What is said against the various forms of government is not said with a view to provoking revolution, of course, but is said that thoughtful men and women might consider the only way that leads to a condition of righteousness, peace and happiness. Such a desirable condition of righteousness, peace and happiness could never have been employed under a monarchy, aristocracy, democracy, communism, socialism or sovietism, or any like form of government. 23

By definition, a theocracy, to the Judge, was a "government of which the chief ruler is Jehovah God. He is the maker and Executor of its laws through his constituted agencies."24 And the Jehovah's Witnesses were one of the agencies through which God was attempting to realize his purpose. Concerned more with God's rule than man's rule, the Witnesses view government through theological eyes. The forces of evil should be checked by God's power, not by man's power. In an address to a throng gathered in Yankee Stadium on August 6, 1950, the present leader of the sect, Mr. Knorr said, "the Witnesses alone are preparing for the final battle on earth between good and evil, the Armageddon that would lead to his predicted earthly paradise."25 Thus the whole earthly struggle is looked upon as the great battle of Armageddon which is predicted in the Bible.
23 Ibid., p. 248 .
24 Ibid.
25 New York Times, August 7,1950, p. 11. 
11

If these evangels of God present a dim view on earthly government, to them there is sacred justification, for Jehovah God so ordained it. Their attitude stems from the belief that the government of this world can do no good, and will only contribute to greater follies. Thus with perfect confidence, Judge Rutherford could say, "The combined testimony of the world's greatest statesmen is that the governments of earth are not only imperfect but generally are corrupt. "25 And through the ages this corruption has continued with no sign of any improvement.

For centuries men have struggled to establish a good government that would satisfy the desires of the honest. Now it is admitted that all efforts have failed to accomplish such result. There is a reason. of course Jehovah foreknew and foretold the futile efforts of man. The time is now ripe for the mind of man to be turned to the sober and candid examination of God's plan for the establishment of a righteous government on earth which will fulfill the legitimate desires of a11.27

It is as simple as that! To these believers, the word is authority, and Rutherford's interpretation of the word is correct and authoritative. "They are firmly persuaded that they are in the possession of truth, the Truth, in an altogether exceptional degree, measure and manner." 28

\footnotetext{
26 Rutherford, Government, p. ii.

27 Ibid.

${ }^{28}$ Pike, Jehovah's Witnesses, p. 31.
} 
12

The Presioent of the Society currently is Nathan Homer Knorr. Born in Bethlehem, Pennsylvania, in 1905, he was elected to his present position in 1942 upon the death of Joseph $\mathrm{F}$. Ruthezford. Wrile still attending high school in Allentown Pennsylvania, he and his parents were introduced to the watchtower. Under the influence of the publication, young Knorr -impressed at the outset -- "became convinced of their Biblical truthfulness."29 By the time he was 18, he was a "full-time preacher," and by 1940, he had merited the position of a Director and Vice President of the Watchtower Bible and Tract Society. Although his activities with the Society have surpassed that of his predecessors, he has not published as prolifically. In all fairness to Mr. Knorr, it must be said that it is still too early in his career to present an adequate personal evaluation. Not as colorful and fiery as Russell, and certainly not as sophisticatedly aloof as Rutherford, President Knorr, despite his lack of higher formal education, seems to be an able leader, and generally commands respect from his constituency as well as from without.

In American constitutional law, the Jehovah's Witnesses are best known for their recalcitrance against some of the prevaling rules and ordinances of the community. To understand why these zealous brethren are "irritants" to the calm of a stable society, the make-up of their character and attitude

29 Ferm, Religion in the Twentieth century, p. 380. 
13

must be examined. As a provincial group they are shunned by the public, and have proved to be extremely unpopular in certain areas. Their unpopularity is pronounced wherever there exists a strong religious bias in a community. Hence, they have found it "tough-going" in a predominantly Catholic, Baptist, or Nazarene community. As described by one writer, they are "generally rustic in personnel," 30 and each member is a minister of God. This is one of the reasons for the dilemma of the courts, viz., part-time workers requesting ministerial exemption from military service (see below), or the right of these men to perform the various services traditionally reserved to properly ordained ministers. Inasmuch as they are all ministers, they contend that their orders come directly from one supreme source, and that source is Jehovah God. Such ministers go about teaching the people of all nations that their one and only hope is in the "Kingdom of Jehovah under Christ Jesus which has been established to rule over earth and which will replace all governments of man."3I The members of this somewhat anarchistic sect are proud over the fact that they are the dispossessed -- on earth that is. Their "emotional appeal is in the Millennialism according to which the dispossessed will in due course inherit the earth." 32 under

30 Chard Powers Smith, Yankees and God (New York: Hermitage House, 1954), p. 425 .

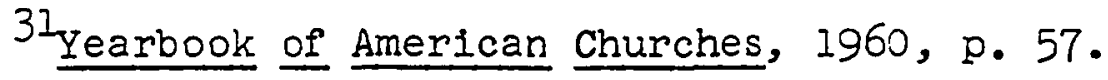
${ }^{32}$ Smith, Yankees and God, p. 425. 
14

this belief it becomes a tremendous service to be "martyred" -if need be -- by the courts. On earth they expect not to be treated royally, but the time will be at hand soon, when the course of events will change, and the heavenly tribunal with the highest Judge on the throne will adjudge and reward his faithful witnesses.

The belief in the Biblical doctrine of God's rule of a thousand years before the final judgment, has earned for the Witnesses the title, "Millennialists。" Most Christian groups believe in the millennium, differing mainly as to the time and condition under which the period shall be made manifest. Coupled with their millennial belief, the Witnesses have relied strongly on prophecy, especially the prognostications of Russell and Rutherford. It was Russell who calculated by his own time table, that the second coming of the Lord would occur in 1874 , and the establishment of the Kingdom would be in 1914. To substantiate his claims for the Second Coming he pointed to such occurrences as the "First International" given rise by Karl Marx, and other phenomena such as, sky scrapers, telephones, submarines, gas engines, and numerous other "evidences" of a new age. While today, 1874 has been generally obscured by the momentousness of 1914, it still remains on the Jehovah's Witnesses time table as a fulfillment of prophecy. Of course the most remarkable year is still 1914 to these believers. The global war which began about that period further attests to their belief that God's Kingdom was established. It was 
thought earlier that the return of Christ would be physically visible, but the doctrine has been since interpreted to mean that his reappearing is apparent only in spirit. The re-interpretation of doctrine is not peculiar to the Jehovah's Witnesses alone. As a matter of survival in many cases, other_denominations and sects have engaged in the same practice. Even the Supreme Court of the United States has periodically reinterpreted and vacated earlier judgments; the most notable in this connection being the Flag-saiute cases, 33 between which at least two Justices openly and publicly confessed their error. In the same way that the court has kept the Constitution meaningful by a rare but necessary "flexible" interpretation, so have the witnesses -- at proper occasions utilized the same process. To the believers of the Lord's return, in essence, there is not much difference as to whether He can be seen physically or spiritually, the effect should be the same in either case. Thus the reinterpretation of the Lord's return by the Witnesses, is no more than a re-statement of an essential belief.

There can be no denying that 1914 was a momentous year in many respects. Some may make similar claims for the year 1916, or 1941, or 1945, but the Witnesses harbor no doubts that 1914

33 Minersville School District et. al. v. Gobitis et. al., 310 U.S. 586, (1940); and West VirgInia Board of Eoucation et. al. v. Barnette, et. al., 319 U.S. 624 (1943). Both of the se cases and the attitude of the Justices are discussed in another chapter. 
16

was the ending and beginning of a new epoch. It was Russell who said:

Those of you who have lived through this period will no doubt add your own personal testimony to the unmistakable trend in human history singe 1914. To deny the change is to ignore the facts. 34

To support further their contentions, the witnesses quote freely (and sometimes quite out of context) from the lips and pens of various sources. "The last completely norma? year was 19I3, the year before world War I began."35 "We have not had a peaceful world since 1914."36 "It is indeed the year 1914 rather than that of Hiroshima which marks the turning point in our time."37 "It seems likely" that when the history of the twentieth century is written, fizgust 4,1914 , the day hostilities became general in Europe will loom larger than even the date of the outbreak of the Second World War, or the dropping of the first Atomic bomb." 38 And, "the first war marked a far greater change in history. . . since 1914 the world has had a new character. "39

34 Quoted in Macmillan, Faith on the March, p. 57.

35 Washington Times Herald, March 13, 1945, editorial. Quoted in Ibid., p. 56 .

36 Harold C. Urey, in Cleveland Plain Dealer, December 9, 1951. Quoted in Ibid.

37 proiessor Rene Albrecht-carrie, in scientific Monthly, IXXIII (July 1, 1951), p. 16. Quoted in Ib1d., p. 57.

38Edmonton (Alberta, Canada) Journal, August 7, 1954, editorial. Quoted in Ibid.

39 New York Times Magazine, August 1, 1954. Quoted in Ibid. 
17

There is yet another important date in the unfolding plan of God, 1918. It was in that year that Christ made his entry into the Temple for cleansing. As if to commemorate these epoch dates, "in 1914 an eight-hour motion picture or 'photo-drama' of Creation was shown. In 1919, 8,000 'ministers' or 'witnesses' in convention agreed to advertise, advertise, advertise the King and the Kingdom." 40

To generalize about the Jehovah's Witnesses is neither desirable nor practicable. At best, it can be said that they are determined about their task and convinced of the authenticity of their tenets. "In intention there is an honesty and objective mysticism in this movement, "4I while at the same time, "there is a sinister element in some cuarters." 42 Perhaps the best description of them is the following:

from all accounts Jehovah's Witnesses are pretty trying zealots. They show a degree of intolerance that makes their own claims for toleration almost laughable. They annoy quiet littie communities with their unwelcome attentions. But they represent a species of religion, and that religion happens to put its case to its prospective adherents through speeches, pamphlets, the playing of phonograph records, and the Iike. - . 43

40 Herbert Wallace Schneider, Religion in Twentieth Cantury America (Cambridge: Harvard Univ. Press, 1952), p. 87. 4 Smith, Yankees and God, p. 425. 42 Ibid.

43 Raymond Moley, "The Boot is on the other Leg," NewsWeek XIX (June 29, 1942), p. 68. 
18

If they represent a "species of religion," it is not by their own definition. "The Jehovah"s Witnesses deny indignantly that their movement is religious." 44 This may sound strange to those who have heard them speak or read their literature, for their teachings are replete with scriptural references and the theological language of God, the Kingdom, sin and salvation. To the witnesses, theirs is not a religion because "religion is doing anything contrary to the will of Almighty God, religion is of the devil."45 They believe that "religion, contrary to its claims oi being Christian has betrayed the people's rights into the powers of the Demons. Thereby religion turns mankind away from God's Kingdom, the theocracy."46 Hence, the Witnesses view the meaning of religion in a negative sense, that is to say, Godlessness. And every enterprise on earth, other than this small group of faithfuls through whom God's purpose is revealed, is part of the great void. In this context it is not difficult to make a case justifying the actions of the "draft dodgers" and the "Scripture peddlers."

${ }^{44}$ Charles Samuel Braden, These Also Believe: A Study of Modern American Cults and Minority Relisious Movements (New York: Macmilian Co., 1949), p. 358 .

45 Religion Reaps the Wildwind (Brooklyn: Watchtower Bible and Tract Society, 1944$), \bar{p} .58$. Quoted in Ibid.

46 Henry Conrad Maehlman, The Wall of Separation Between Church and State (Boston: Beacon Press, 1951), p. 99 . 
Thus do the faithful witnesses of God, Jehovah's Witnesses, preach unto all the peoples of the earth, the Trutb of God: The gospel written in God's holy Book; undaunted by the Devil, Godsustained. - . They do teach to men what God's Word first taught them; they do not hold vain teachings without basis in that Book which has all Truth, as do all other churches, which counterfeit the doctrines of the Lord with imaginings of men. They have the Way, and no man enters life but by the way, and there is little time. 47

Taking their cue from the Biblical account "and I heard the number which were sealed: and there were sealed an hundred and forty and four thousand, "48 the Witnesses jelieve that in the ultimate heaven there will be present only 144,000 followers. Critics have remarked that this number has already been reached by the sect and there is no more reason to proselyte. In the first place, the Witnesses will not grant that this number has been reached, and if it were, there is no way of knowing when or who they are. There is then, reason enough for sustained effort, for the Witnesses believe in a heaven on earth. Those followers who do not make up the 144,000 (sometimes referred to as "Jonadabs"), will remain on earth, a sort of a "consolation heaven." The earth, of course, will have to be re-made into a heaverily likeness which only God has the power to do.

\section{${ }^{47}$ Roger D. Quidam, The Doctrine of Jehovah's Witnesses} (New York: Philosophical Library, 1959), p. 24 .

$$
{ }^{48} \text { Revelation } 7: 4 \text {. }
$$


As for a celestial heaven. - only 144,000 [w1ll] share that with God and His Son. The others. . [will] live forever in a promised land on earth - . . An earth on which no natural disasters occur; on which your fellow creatures enjoy complete health and permanent youthful beauty and vigor and where never a hospital or a graveyard mars the grandeur of perfectly cultivated land. An earth filled with the knowledge of God. 49

This very attractive doctrine is even more enticing because the Jehovah's Witnesses do not believe in an eternal hell. This is another one of several doctrines which is contrary to the American Protestant mainstream, and has only served to exacerbate the strained relationship between traditional protestantism and the Jehovah's Witnesses. According to this belief, all -- including the dead -- will be given another opportunity during the judgment, and the non-believers will be completely obliterated, even from memory. Eternity then, will only be composed of heaven, two of them at that! The unpopularity of this zealous band of crusaders stems from many sources, but theologically, the belief in a hell-less eternity has been the cause of much persecution, especially from the members of other religious orders. In general, "for conscientious cussedness on the grand scale, no other aggregation of Americans is a match for Jehovah's Witnesses." 50

49 Commentary on President N.H. Knorr's Address, New York Times August $7,1950, \mathrm{p} .11$.

50 "Jehovah's Witnesses Make Hate a Relinion," Saturday Evening Post (September 14, 1940), p. 18. Editorial. 
21

The numerous encounters with civil authorities have been due primarliy to the dogged determination of this band of believers to hurry the Kingdom on earth. In their zeal to propagate the word, they have increased the tempo in their "salesmanship." Not satisfied with mere door-to-door contacts, their strategy has been to reach the multitude through other media.

In 1946, 80,000 Witnesses in convention at Cleveland, launched another magazine, Awake! Meanwhile increasing radio broadcasts led to the establishment of Radio Station WBBR, Brooklyn. By these thoroughly modern techniques, Jehovah's Witnesses have proclaimed their own version of how God is bringing in his Kingdom.51

The headquarters of the Society is located on $124 \mathrm{Co}-$ lumbia Street, Brooklyn, New York. This is the nome of the Watchtower Bible and Tract Society. Better known as "Bethel," the "home which the Witnesses built and own, is an imposing ten-story rose-brick structure." 52 The building cost a million dollars to put up in 1949, "and not only that, it was built on the cite of Henry ward Beecher's home." 53 The fact that their

5lschneider, Religion in Twentieth Century America,p. 87. $52 " I ' d$ Like to Talk to You a Minute," The New Yorker, XXII (June 16, 1956), p. 72. This excellent article by a "roving reporter," depicts the life and beliefs of the Jehovah's witnesses as gathered by a reporter who visited the headquarters of the society and made numerous contacts with the members.

53 Statement made by Ulysses Glass, Public Relations Director for the Jehovah's Witnesses. Quoted in Ibid., p. 74 . 
22

base of operation is located on Beecher's old property, seems to be of some religious significance to the Witnesses. Every one at Bethel is a member of the sect, and each performs his duty as a servant of God. Their salary is meager (in 1956, each member received only $\$ 14.00$ per month), with expenses provided for in the case of travel and special services. To a large degree, the organization is self-sufficient. They grow their own vegetables on a farm in Staten Island, they run their own laundry, dry-cleaning plant, and shoeshop.

Life in Bethel is communal, from getting up at $6: 30 \mathrm{a} \cdot \mathrm{m}$. until lights out at $10: 30 \mathrm{p} . \mathrm{m}$. Meals are taken in the common dining room. What leisure remains after the day's work in office or printingroom or bindery or dispatch room is devoted to 'preaching,' i.e., missionary or propaganda work, in Brooklyn and the neighboring districts. 54

The community is reminiscent of the ventures in the communal life of Brook Farm, New Harmony and other communistic schemes which flourished during the early l9th century in this country. Each of these early experiments however, had no lasting effect and passed from the scene within a few years. Bethel, unlike New Harmony and its sister organizations, has never experienced lack of growth. As a matter of fact, there is a waiting list of prospective workers. Members usually sign up for a limited period, e.g., three years, but many of them stay on to make it a life-time service.

54 Pike, Jehovah's Witnesses, p. 91. 
Although each of the Witnesses is considered to be ministers of the gospel, there are two general classifications; the "Pioneers," and the "Publishers." The difference between them is defined in terms of the actual time allotted to missionary work. The Pioneers are consiciered to be full-time workers, while the Publishers are expected to devote less time to the task.

Mention has already been made to the erfect that in the American experience, this fairly small group of dissident zealots have met with public censure for various reasons not the least of which is their constant opposition to what has heretofore been unquestionably part of a way of living. Their refusal to salute the flag, and the opposition to religion in general are good examples of non-conformity. Furthermore, the Witnesses refuse to submit to blood transfusions and in some instances have refused to be vaccinated. While the problem of vaccinations has now been settled in most cases thus permitting the Witnesses to receive them, blood transfusions are still forbidden. This taboo is based on the Biblical principle fopen for interpretation) that man should not "drink blood" In the modern age, they have engendered greater public indignation by their attitude toward a possible nuclear war. While the world frets and bemoans over the terrible immorality of possible nuclear warfare, to the Witnesses, this may be the consummation of the highest morality. As "waiters" and "watchers" for God's Armageddon, some actually believe that a nuclear war may be the 
24

preliminary action to the long-awaited event.

Jehovah's Witnesses constitute the one group of people in the world who not only feel no anxiety about the threat of nuclear war but actually look forward to one with considerable pleasure, since they believe that it might prove to be the last earthly upheaval before Armageddon -- the final battle between the forces of good and evil that is so grimly predicted in the Bible. The Witnesses bank strongly on Armageddon for it is their comforting conviction that they will be the sole survivors of the cataclysm. 55

The Witnesses are not adverse to war, thus they are not pacifists in the true sense of the term. 56 They have refused military service up to now on the ground that the previous wars were not "God's wars." As to whether they would consider a possible global nuclear holocaust a part of God's war, is an academic question. According to one writer, the Witnesses have not engaged in previous wars "because they think that Jehovah is not concerned with /them7. - .most of them believe Satan is 'running the whole show,' and therefore they will have nothing to do with it."57 on this issue the Witnesses have been criticized because no war between nations can be "the execution of God's judgment. - .because all the governments are on the side of Satan and only the Witnesses are on the side of

55 The New Yorker, (June 16, 1956), p. 72.

${ }^{56}$ Pacifism and military service are discussed in a later chapter.

57W.E. Garrison, Review of The Jehovah's Witnesses, by H.H. Stroup, Christian century, IXII (June 20, 1945), p. 734 . 
God."58 And since Jehovah's Witnesses refuse to go to war, there could never be a war in which God had a part. To this charge, the Witnesses would say that God's judgment can be executed without their physical participation, but upon the knowledge that God has "Intervened," the Witnesses too will join in. Neither participation nor non-participation by these faithfuls can alter Jehovah's judgment, rather, it is quite the other way around. God's judgment is the first cause, and the participation by his followers is the natural effect. From the standpoint of criticism, this type of argument leads nowhere, for no one can determine for the other precisely at what point God has decided to take an active part. It is this kind of a problem to which the court has been frequently subjected, and has carefully avoided to elaborate.

Although historically America has not been devoid of the experience of religious persecution, from a practical point of view, it must be concluded that persecution of this nature is no longer an important characteristic in the American makeup. This is not to say however, that religious persecution is now non-existent.

Unfortunately, discrimination against certain religious groups still prevails in many parts of the United States. Small dissident groups like the Jehovah's Witnesses still have a hard time; and even members of so powerful a group as the Catholic church have suffered considerably from 
religious prejudice in those communities where they constitute a minority. 59

The truth of these words does not necessarily compel sympathy, at least for the Jehovah's Witnesses, for they believe that it is their lot, while on earth, "to suffer and be persecuted for His sake."60 To them it is a welcome opportunity, a time of grace and glory without which they would. be hard-pressed for an explanation of prophecy fulfilled. America has not always been unkind to minorities as such, unIess the minority happened to be a convenient scapegoat for "sin," or a group to be exploited. Hence it is true that,
among the minority groups in our population whose rights have always been in danger, the Negro has perhaps been most sinned against. . . A second illustration is found in the recent widespread in- terference with the freedom of religion, press, and speech of members of the Jehovah's Witnesses sect. 61

The concept of freedom in its exact scope has always been nebulous, thus the New York Times could safely editorialize, "the boundaries of the individual freedoms are bound to be questioned when small and unpopular groups challenge them." 62

59corliss Lamont, Freedom is as Freedom Does: Civil Liberties Today (New York: Horizon Press, 1956), p. 215 .

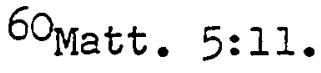

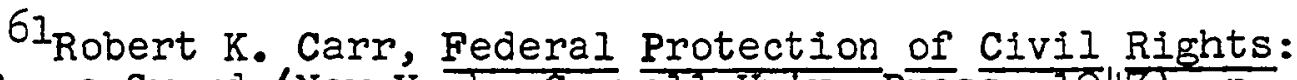
Quest for a Sword (New York: Cornell Univ. Press, 1947), p. 15. $62_{\text {New York }}$ Times, March 11, 1943, editorial. 
The difficulty to fix these boundaries is magnified in the case of the relationship between the Jehovah's Witnesses and the government, "for obviously a government which is the agent guaranteeing liberty cannot permit an abuse which would destroy both the government and the guaranteed liberty. . " 63 Historically, the enfoyment of liberty has been contingent upon citizenship. That is to say, membership in a politically constituted body. The Jehovah's Witnesses, although adverse to the idea and practice of general government have never disclaimed citizenship. 64 Thus they "assert and rely upon citizenship rights which guarantee freedom of speech, press, assembly, conscience, and freedom to worship Almighty God, in order to protect [their] field of preaching."65 The basis for their citizenship in the community is once again scriptural. This scriptural basis has been given added emphasis and legal standing, by the United States Supreme Court in Edwards $V$ California. 66 To the delight of the witnesses, Justice Jackson in a concurring opinion said;

6 İIbid.

64 The Jehovah's Witnesses have brought before the court several cases concerning naturalization, citizenship, etc., which are examined in another chapter.

65Defending and Legally Establishing the Good News (Brooklyn: Watchtower Bible and Tract Soclety, l950), p. 4. This is a booklet prepared primarily to instruct the membership in the proper method to present cases before the courts. $66_{314}$ U.S. 160 (1941). 
The power of citizenship as a shield against oppression was widely known from the example of Paul's Roman Citizenship which sent the Centurion scurrying to his higher-ups with the message; 'Take heed what thou doest: for this man is a Roman.' I suppose none of us doubts that the hope of imparting to American citizenship some of this vitality was the purpose of the.. Fourteenth Amendment. 67

Armed with persistent determination, no more powerful ground for action can be laid for these undaunted missionaries than first, God's Holy word, the use and adaptation of which they are masters; and secondly, an admonition by a justice of the high tribunal quoting from one of the epistles of Paul who himself was one of the early "Witnesses" of Jehovah.

For those, such as the Jehovah's Witnesses, who interpret the issue of citizenship along a monistic line, that is, both secular and spiritual citizenship as being an undivided whole, the problem is easily reconcilable because there is only one authority. This means that the earthly government must treat its citizens according to the rules laid down by God. To this scheme of thinking there are two great drawbacks, and the Supreme Court inevitably faced both of them in dealing with the Jehovah's Witnesses. First; as to what God himself required of his own citizens, the witnesses claimed that no earthly institution could decide. Therefore, the supreme Court, the agency which was called upon to settle these cases,

67Ibid. Quoted in Defending and Legally Establishing the Good News; p. 4 . 
29

Under such a doctrine, had no authority to question or decide upon the validity of the claims made by the witnesses concerning what they believed to be spiritual commands. In other words, they could not be challenged. The second drawback is that to the court, the duality of citizenship did not exist. Justice Jackson's reference to Paul's Roman citizenship was unfortunate in view of the fact that the inference for duality is not altogether unjustified however erroneous the reference may be. Paul, not unlike the Jehovah's Witnesses in at least one respect, spoke of heavenly citizenship while at the same time demanding his rights as a Roman citizen. Constitutionally, there is nothing to be said for spiritual citizenship, but the point is, religious groups frequently cannot seem to divorce the earthly from the heavenly. The Court deals with the former; the Jehovah's Witnesses deal with both and emphasize either because it makes no difference which is to be recognized if both are viewed as one and the same.

Somewhat axin to the issue of citizenship, there was another problem which was not handled by the Court -- perhaps because under the conditions, it could not. The Jehovah's Witnesses contended adamantly throughout that they were opposed to religion. To them religion was a "snare and a racket."68 Yet the Supreme Court recognized that the Jehovah's Witnesses'

${ }^{68}$ See especially chapter $V$ for a discussion of their view on religion. 
30

contention for freedom of religion in many of the cases was a valid contention and assumed that the sect was a religion. The Constitution does not define religion, and in the cases concerning the Jehovah's Witnesses, neither did the Court. To the Witnesses, obviously, they did not constitute a reIigion -- else why would they denounce it -- but to the Court they did, and thus came under the meaning of the First Amendment and the due process clause of the Fourteenth Amendment. The paradox 69 is that those who opposed religion were claiming a right reserved only to religion. To a certain degree, the problem was over semantics, but this was a unique situation over which the court was not totally unaffected. Like the issue over citizenship, this was not a constitutionally controvertible matter. It was sufficient that the court dealt with the Jehovah's Witnesses as citizens of an earthly institution, and members of a religion, and so applied the Constitution regardless of how the Witnesses themselves felt over these matters. The court will not, and cannot deal with anything beyond the scope of the constitution.

69 For a brief reference to this "paradox," see Fordham Law Review, II (November, 1942), p. 309. 


\section{CHAPTER II \\ BY WAY OF DUE PROCESS}

The legal setting for the Jehovah's Witnesses cases before the Supreme court, was given constitutional meaning by the due process clause of the Fourteenth Amendment. ${ }^{1}$ Historically, the guarantees of religion, speech, press, and assembly provided in the First Amendment of the Constitution of the United States, were instituted as a protection from infringement by the Federal Government and not state authorities.

Until a few years ago it would have been said with entire truth that, so far as the federal Constitution was concerned, any state was at liberty to deprive its residents of their freedom of speech or freedom of the press -- except as those rights happened to be guaranteed by the Constitution of the state concerned.2

That this practice is no longer true is evidenced by the numerous decisions handed down by the court in recent years.

I The due process clause of the Fifth and especially the Fourteenth Amendment, has been the topic of discussion in many articles and monographs, and is a well-worn path in legal writing. Some of the notable publications are: John H. Leek, "Due Process: Fifth and Fourteenth Amendments," Political Science Quarterly, IX (June, 1945), p. 188; Charles Warren, "The New 'Liberty' Under the Fourteenth Amendment, "Harvard Law Review, XXXIX (Feb., 1926), p. 431; Joseph B. James, The Framing of the Pourteenth Amendment (Urbana: Univ. of III. Press, 1956); VIrginia Wod, Due Process of Law 1932-1949, The Supreme Court's Use of a Constitutional To01 (Bat on Rouge: Louisiana State Univ Press, 1951), $436 \mathrm{pp}$; Rodney L. Mott, Due Process of Law (Indianapolis: Bobbs-Merrill Co., 1926). ${ }^{2}$ Leek, Political Science Quarterly, IX, p. 188. 
32

"It is notorious that the concept of due process has been the occasion of more litigation than any other single clause in the Constitution. . . and most of them have occurred since the eighteen-eighties." 3

It was not until the Civil war and its aftermath that certain individual guarantees underwent a substantial transformation in terms of protection from local authorities. Because of the reluctance of some to grant the Negro slave his new-found freedom, legal measures were devised to safeguard his emancipation. The abolition of slavery meant very little to those, who for various reasons thought that certain privileges incident to free men did not belong to a particular group of the human race. The Constitution itself, in some ways seemed to sanction this view. In the Slaughter-house Cases, ${ }^{4} \mathrm{Mr}$. Justice Miller said, "Among the first acts of legislation adopted by several of the states. . .were laws which imposed upon the colored race onerous disabilities and burdens," which necessitated the passing of certain constitutional provisions to protect the rights of the Negro race. 6

3 Ibid.

${ }^{4} 16$ wall. 36 (1873).

$5_{\text {Ibid. }}$

GThese constitutional provisions were especially the Thirteenth, Fourteenth, and Fifteenth Amendments. Mr. Justice Milier stated in the Slaughter-house Cases, Ibid., that of all these Amendments, "only the Fif'teenth Amendment mentions the Negro by speaking of his color and his slavery." Never- 
But the provisions by themselves proved to be insufficient to afford the protection sought by minority groups. The attempts were first centered on the privileges and immunities clause, but when these failed, attention was shifted to the due process clause. "Every possible constitutional clause was dragged out in the famed Slaughter-house Cases, but the court rejected them all."7 The privileges and immunities clause is restricted to citizens -- a broad enough term -- but the due process clause is restricted to "persons," which certainiy affords more latitude then "citizens." Furthermore, the due process clause is a guarantee affecting the denial of "life, liberty and property," the meaning of which is not clearly forthcoming in every case. And most cases deal -- in one way or another -- with life, liberty, or property, especially "liberty," in cases involving fundamental individual guarantees.

The application of the due process clause to the first Amendment guarantees has been realized through a long and careful process which has yet to be reconciled to legally satisfactory proportions. The definition of due process itself has been, in the words of Mr. Justice Milier, "a gradual process of judicial inclusion and exclusion." 8 The main function of

theless, the other Amendments were "addressed to the grievances of that race, and designed to remedy them as the Fifteenth."

${ }^{7}$ Leek, Political Science Quarterly, LX, pp. 189-190. 8 
34

the court is not in defining terms, but no tribunal can escape this responsibility if the end which it seeks is to be related to the intent of the law. But in the case of due process as prescribed in the Fourteenth Amendment, through the years since its adoption, the Court has availed itself or a broad interpretation. It is significant that in relation to the other constitutional provisions,

the Supreme Court has adopted a much broader interpretation of the Fourteenth Amendment -- particularly in regard to the word 'liberty' as found in the due process clause. By this gradual process of interpretation, not only has much of the federal Bill of Rights been extended to the states, but the due process clause of the Fourteenth Amendment, which presumably meant the same thing as its older brother of the Fifth Amendment, has come to mean something quite different.9

This development is not unwarranted since the clause itself, in general terms, offers very little specific restrictions. If there is any restriction at all, "intent" seems to be the most pronounced.

It has been established that the Fourteenth Amendment was designed primarily to protect the right of Negroes. Therefore, it has been argued, any extension of the rights contained therein to others is perhaps a violation of the Amendment. Such a contention overlooks the fact that in the most fruitful period of adjudication dealing with due process, viz.,

9 Ieek, political Science quarterly, LX, p. 188. 


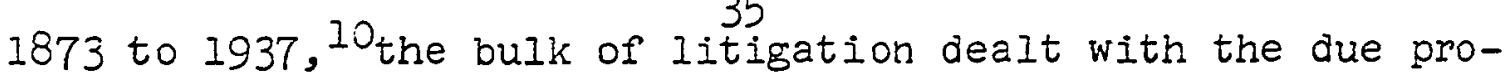
cess clause as affecting economic relationships. ${ }^{11}$ In pràctically all areas affecting individual guarantees where states sought to impose restrictions, the federal courts have been in some way involved. And a goodly number of these cases dealt with economic measures. Undoubtedly, the cases dealing with economic regulation did not affect First Amendment freedoms directly, but they laid the groundwork for cases that did. The most notable of these was Gitlow v. New York. 12 This "starting constitutional development" 13 permitted access to the courts over matters hitherto unacceptable. The doctrine expressed in Gitlow in a "casual, almost incidental" 14 manner by the majority of the Court was the legal route which enabled

a fundamentalist religious group called the

10These dates have reference to the Slaughter-house cases and West Coast Hotel Company v. Parrish, 300 U.S. 379 (1937).

IIThe cases involving the due process clause in economic matters are too numerous to list. Some of the more celbrated are: Munn v. IIIinois, 94 U.S. 113 (1877); Lochner v. New York, 109 U.S. 45 (1905); Muller v. Oregon, 208 U.S. 412 (1908), Bunting v. Oregon, 243 U.S 426 (1917); Adkins v. Children's Hospital, 26I U.S. 525 (1923); Nebbia v. New York, 291 U.S. 502 (1934); National Labor Relations Board v. Jones and Laughlin Steel Corp., 301 U.S. I (1937); OISen V. Nebraska, 313 U.S. 236 (1941): and Giboney v. Empire Storage and Ice company, 336 U.S. 490 (1949).

$$
12268 \text { U.S. } 652 \text { (1925). }
$$

13C. Herman Pritchett, The American Constitution (New York: McGraw-Hill Book Co., Inc., 1959), p. 390.

$14^{\text {Ibid. }}$ 


\begin{abstract}
36
Jehovah's Witnesses [to embark7 upon a course of aggressive evangelism, one of the most important results of which was the rapid development, along a zigzag course, of the meaning of the constitutional guarantee of freedom of religion, speech, and the press. 15
\end{abstract}

As it has been true in many cases, the importance of the Gitlow decision is not found in the substance of the case but in a remark made by Mr. Justice Sanford which was no more than dictum, to wit;

For present purposes we may and do assume that freedom of speech and of the uress -- which as protected by the First Amendment from abridgment by Congress -- are among the fundamental personal rights and 'liberties' protected by the due process clause of the fourteenth Amendment from impairment by the states. 16

Such a daring doctrine was accepted with mixed emotions. It did not stir up immediate controversy, but in the decades which followed, almost every case affecting civil liberties was based in some form upon this bold new doctrine. on the whole, the interpretation was generally acceptable only as applied to the Pirst Amendment freedoms. Mr. Justice Sanford's statement was accepted as

announcing with extrorrdinary brevity, a view which

15Eleanor Bontencou (ed.), Freedom in the Balance: Opinions of Judge Henry W. Edgerton Relating Eo Civil LiberEies (New York: Cornell University Press, 1960), p. 16.

$16_{\text {Gitlow }}$ v. New York, p. 666. 
Lthe supreme court] had more than once rejected in the past. The enlargement of the Fourteenth Amendment which has resulted from this single sentence has already profoundly increased the liberty of the individual, at the expense of the powers of the states.17

In the decade of the forties when the court was burdened with numerous cases affecting the Jehovah's Witnesses, it was a well settled principle that the first Amendment was an essential part of the due process fabric. The witnesses only pressed the court for the irritating but necessary elaboration of what constituted these freedoms. Again referring to Mr. Justice Sanford's classic statement in the Gitlow case, a prominent practitioner before the bar said:

This interpretation of the scope of that provision has since been recognized in numerous decisions, and is now settled law beyond dispute. The cases involving the numerous activities of the Jehovah's Witnesses are points on the line that define the scope of the protection accorded these rights by the due process clause of the Fourteenth Amendment in the field where freedom of expression and disseminating ideas is employed as a means for propagating religion.18

It is most significant that within a few years after

17John Raeburn Green, "Liberty Under the Fourteenth Amendment," Washingt on University Law QuarterIy, XXVII (Summer, 1942), p. 521. This is one of the f'ew articles appearing in law journals which covers quite thoroughly all the Jehovah's Hitnesses cases up to the time of writing.

18 Edward F. Wite, "The Debt of Constitutional Law to Jehovah's Witnesses," Minnesota Law Review, XXVIII (March,1944), p. 215. 
38

Gitlow and in subsequent decisions, the court, relying on the due process clause, invalidated state action relating to freedom of speech, 19 freedom of press, 20 the right of peaceable assembly, 21 and free access to $r \epsilon$ igious activities. 22 Thus the prevailing view of the court was that the infringement of First Amendment freedoms, whether conditioned by the central government or state governments, was repugnant to the fundamental rights protected by the nature of the United States Constitution itself. And all this was accomplished through the interpretation of a brief clause in one of the amendments to the Constitution.

The Fourteenth Amendment placed a prohibition upon the states, denying them the right to deprive any person of life, liberty or property without due process of law or to abridge his privileges or immunities. It also secured all persons against the abridgment of the fundamental personal rights and liberties which cannot be denied them without violating the principles and justice which lie at the

19 Fiske v. Kansas, 274 U.S. 380 (1927); Herndon v. Lowery, 301 U.S. 242 (1937); Thornhill v. Alabama, 310 U.S. 88 (1940); Kunz v. New York, 340 U.S. 290 (1951); Bridges v. California, 314 U.S. 25 ट (I94I).

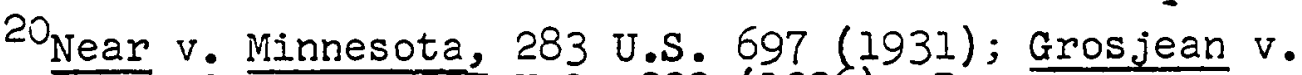
American Press company, 297 U.S. 233 (1936); Pennecamp v. Florida, 328 U.S. 331 (1946); Cr ing v. Harney, 331 U.S. 367 (1947).

${ }^{21}$ De Jonge v. Oregon, 29'3 U.S. 353 (1937); Hague v. C.I.O., 307 U.S. 496 1939). A case like Hague is extremely important because it overlapped into the area of free speech and press also.

${ }^{22}$ Cases affecting religious freedom are discussed in subsequent chapters. 
base of our civil and political institutions. 23

The provision of the First Amendment is clear in that It declares "Congress shall make no law," whereas the Fourteenth Amendment imposes a restriction upon states. But there are two provisions in the Fourteenth Amendment which seem to make it possible for the Supreme Court to hold the states accountable for action infringing religious freedom. These are: (1) no state "shall make or enforce any law which shall abridge the privilege or immunities of citizens of the United States," and (2) no state shall "deprive any person of life, liberty, or property, without due process of law."24 To sum up what has already been discussed, the narrow interpretation invoked by the Court on "privileges and immunities," has made the clause unavailing in cases involving religious liberties. But the same has not been true of the interpretation accorded to the term "liberty." Here, the Court has permitted a broad interpretation.

In this "startling constitutional development" which has virtually "transferred" the First Amendment into the Fourteenth Amendment, two concepts are worthy of special note.

${ }^{23}$ Samuel P. Weaver, Constitutional Law
tration (Chicago: Callaghan and Co., 1946), p. $36 \frac{\text { Its }}{\text { Adminis- }}$
24 Konvitz, Fundamental Liberties, $p .34$. For a similar outline of the First Amendment, see Wilfrid Parsons, The First Freedom, Considerations on Church and State in the United States (New York: J.J. Little and Ives Co., 1948), pp. 140141. 
40

Neither of these principles was a result of the cases involving Jenuvah's Witnesses, but both were necessary to enable these cases to be heard before the federal courts. The first of these concepts is the incorporation doctrine. Incorporation, or absorption (sometimes referred to as the nationalization of the Bill of Rights), which is the view that the due process clause of the Fourteenth Amendment includes the rights guaranteed in the Bill of Rights, and therefore restricts the state as well as the federal government, has never been fully accepted. It can be safely said however, that the guarantees of the First Amendment have been so incorporated, thus permitting individuals to bring before the federal courts cases in which the states seek to restrict activities regarding the rights of religion, speech, press and assembly, but the same cannot be said for all the other guarantees in the First eight amendments.

Although the citlow case marked an important turning point in the incorporation controversy, the issue itself did not present too much cifficulty as has been true of the guarantees other than those presented in the First Amendment. Neither was it the first case handled by the supreme court involving the applicability of the due process ciause of the Fourteenth Amendment to First Amendment freedoms. The most notable case before Gitlow was Patterson V. Colorado 25 in which the majority,

${ }^{25} 205$ U.S. 454 (1907). 
41

speaking through Mr. Justice Holmes rejected the incorporation idea. Said Holmes:

We leave undecided the question whether there is to be found in the Fourteenth Amendment a prohibition similar to that in the First. But even if we were to assume that freedom of speech and freedom of the press were protected from abridgment on the part not only of the United States but also of the States, still we should be far from the conclusion that the plaintiff in error would have us reach. 26

In the same opinion however, Mr. Justice Holmes provided an escape, for he said, "there is no constitutional right to have all general propositions of law once adopted remain unchanged."27 As opposed to the majority view, it was Mr. Justice Harlan, in his dissenting opinion who said, "I cannot agree. - "28 and thereby anticipated the Gitlow rule which was to come some eighteen years later.

The incorporation controversy is no longer important relative to the rights prescribed in the First Amendment, but the issue has not been resolved concerning many of the guarantees involved in the Bill of Rights in general. For the purpose of this study, the application of the due process clause

26Ibid., p. 462. As late as 1922, in Prudential Insurance company v. Cheek, 259 U.S. 530, Justice Pitney said, "neither the Fourceenth Amendment nor any other provision of the Constitution of the United States imposes upon the States restriction about 'freedom of speech' or the 'liberty of silence." p. 543.

28Ibid., p. 463. 
42

to guarantees other than those mentioned in the First Amendment, is not directly pertinent. But it is noteworthy, that for the same reason which compelled the court to incorporate the First Amendment freedoms within the meaning of the due process clause, the persistent minority has called for a complete "nationalization of the Bill of Rights." Some feel that only the guarantees involving criminal prosecutions should be incorporated, ${ }^{29}$ while others demand adamantly a complete $a b-$ sorption. 30

The second concept - related to the theory of incorporation -- is the "preferred position" argument. Before discussing the principle, as a matter of understanding, it is necessary to examine -- at least briefly - the "reasonable man" rule. Up until the time of the Gitlow case, the "reasonable man" test was applied rather than the preferred position principle in most cases where the latter rule could have been applied. However, the reasonable man test which assumes that legislative intentions should be upheld on the basis that any

${ }^{29}$ See William J. Brennan Jr., The Bill of Rights and the states, Center for the Study of Democratic Institutions (Santa Barbara: Fund for the Republic, 1961).

${ }^{30} \mathrm{Cf}$. Adamson v. California, 332 U.S. 46 (1947), and Bartkus v. IIIinois, 359 U.S. 121 (1959), in which Justices Black and Frankfurter carry on a running "feud" over the incorporation theory. Both refer to the history and the "intent" of the framers, and both come up with opposite views. Black feels that due process covers the Bill of Rights because these rights are fundamental and should be avallable to all. Frankfurter thinks this "is to suggest that the due process clause fastened fetters of unreason upon the states." Adamson, p. 6I. 
43

"reasonable man" would reach the same conclusion as the legislature, was used mainly in cases not directly affecting civil liberties. Thus in civil liberties cases, the reasonable man rule became inappropriate. Mr. Justice Holmes was an ardent exponent of this theory and insisted upon its application more than once. 31 But when the rights of individuals included those of a "fundamental nature," Holmes quickly abandoned the rule. 32

Inasmuch as the reasonable man test seemed unsatisfactory as a guide to be employed in cases affecting basic liberties, the preferred position rule became the weapon with which certain "preferred" liberties were safeguarded. Thus the judiciary as well as the legislature was restricted to higher standards when dealing with First Amendment freedoms. "Stated in an extreme form, the argument is that any law touching communication is infected with presumptive invalidity."33 Mr. Pritchett appends the definition by stating that

a more moderate statement is that, because First Amendment values are so essential to a free society, legislative action infringing those values must be shown to be not only 'reasonably'

3lsee Lochner v. New York. In Meyer v. Nebraska, 262 U.S. 390 (1923), HoImes dissented against the majority opinion which upheld a state law preventing the teaching of the German language in primary schools. This, to Holmes, was a "question upon which men reasonably might differ."

32whitney v. California, 274 U.S. 357 (1927); Gitlow v. New York. These cases were not decided by the preferred position rule as such, but contained the essential nature of the argument. 33 pritchett, The American Constitution, p. 393. 
44

adapted to the attaining of valid social goals but justified by overwhelmingly conclusive considerations. 3

The concept which accords certain liberties a preferred treatment was not the result of any single case, or the makings of any single Justice. But one of the most responsible parties to this development was Justice Cardozo, who said, that the First Amendment freedoms were on "a different plane of social and moral values."35 To Justice Cardozo, freedom of thought and of speech especially, were "the matrix, the indispensable condition, of nearly every other form of freedom, "36 and to preserve liberty and justice, neither could be sacrificed. The preferred position argument, to be sure, was not unanimously accepted by the court. The most outspoken critic has been $\mathrm{Mr}$. Justice Felix Frankfurter, who, in more than one occasion, challenged the preferred position as "mischievous" and nothing more than a process of "short-hand." 37

While it is true that Mr. Justice Cardozo has been credited with the preferred position argument, it was not his origination. He merely provided an intelligible phraseology at a time when the demand for it seemed rather imperative. Mr.

${ }^{34}$ Ibid.

35 palko v. Connecticut, 302 U.S. 319 (1937), p. 326. 36 Ibid.

37see Kovacs v. Cooper, 336 U.S. 77 (1949), and Bridges v. California, 314 U.S. 252 (1941). 


\section{5}

Chief Justice Stone, in at least two notable cases helped to emphasize this rule. In United States v. Carolene Products Company, ${ }^{38}$ the Chief Justice stated in a footnote,

There may be narrower scope for operation of the presumption of constitutionality when legislation appears on its face to be within a specific prohibition of the Constitution, such as those of the first ten amendments, which are deemed equally specific when held to be embraced within the fourteenth. . .39

More than just mischievous, Mr. Justice Frankfurter noted, "a footnote hardly seems to be an appropriate way of announcing a new constitutional doctrine." 40 The preferred position term itself was also a contribution of Mr. Chief Justice stone. If the principles examined thus far have not been directly related to the Tehovah's Witnesses and their struggle before the Court, the term was a direct result of their activity, for it was in one of the most celebrated license tax cases Mr. Chief Justice stone in a dissenting opinion said:

The First Amendment is not confined to safeguarding freedom of speech and freedom of religion against discriminatory attempts to wipe them out. On the contrary, the constitution, by virtue of the first and Fourteenth Amendments, has put those freedoms in

38304 U.S. 144 (1938).

39 Ibid., p. 152 .

$40_{\text {Kovacs }}$ v. Cooper, pp. 90-91. 
a PREFERRED POSITION. 4146

Thus it was in a case involving Jehovan's Witnesses that the Chief Justice popularized the term itself, although the concept, at least to stone, must have been with the framers of the Bill of Rights, if not the fathers of the Constitution.

In according a 'preferred position' to the guarantees of the Pirst Amendment and the incorporation of its substance into the due process clause of the Fourteenth Amendment, Justice Stone relied essentially on the explicit statement of these freedoms in the Bill of Rights and the spirit of the historic insistence that they be expressly set forth. If the Fourteenth Amendment guarantees any liberties which can they be if not these? 42

It is against this reasoning that Mr. Justice Frankfurter has lashed out with bitter verbal salvos, declaring that neither the writers of the Fourteenth Amendment nor the states ratifying them had any inkling that it would be interpreted as a "shorthand summary of the first eight amendments" 43 which would act as restrictions upon states. Furthermore, in the best

4lJones v. City of Opelika, 316 U.S. 584 (1942), p. 608. Discussed in Chapter VI.

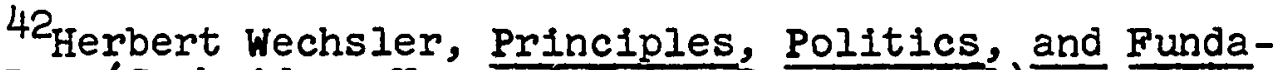
mental Law (Cambridge: Harvard Univ. Press, 196i), p. I34.

$43_{\text {Adamson }}$ v. California, p. 62. This was a self-incrimination case and bears no direct relation to the First Amendment, but the court divided on the question of the applicability of the due process clause of the Fourteenth Amendment to the guarantees embodied in the Bill of Rights, which is specially relevant to the issue under discussion. There are many works on this particular subject. One of the best is, Edward Dumbauld, The Bill of Rights and What it Means Today (Norman: Univ. of oklahoma Press, 1957). 
"Frankfurterian" prose the learned justice continued:

Those reading the English language with the meaning which it ordinarily conveys, those conversant with the political and legal history of the concept of due process, those sensitive to the relations of the states to the central government as well as the relation of some of the provisions of the Bill of Rights to the process of justice, would hardly recognize the Fourteenth Amendment as a cover for the various explicit provisions of the first eight amendments. 44

In a way, the Jehovah's Witnesses are indebted to tradition and the democratic values imbedded in American history for the judicial recognition they received in their stringent demands. Mr. Justice Cardozo's remarks that certain guarantees embodied in the Bill of Rights are the very essence of "a scheme of ordered liberty, "45 and certain guarantees are "so rooted in the traditions and conscience of our people as to be ranked as fundamental," 46 are evidences of this fact. It is undeniable that the Jehovah's Witnesses cases were given constitutional meaning by the incorporation principle, and the principle itself was, to a large degree, the outgrowth of a tradition. Thomas M. Cooley discussed carefully this revered tradition, putting special emphasis on religious liberty. It was his contention that some things were "not lawful in any of the

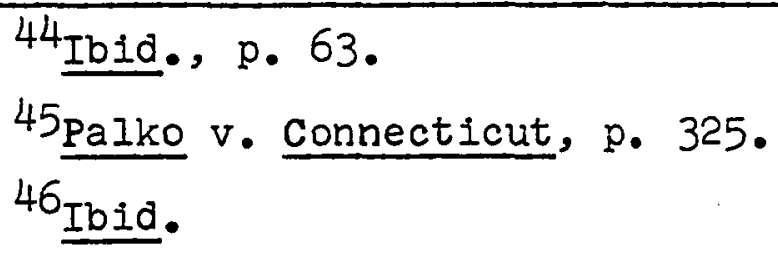


American constitutions." 47 These were:

1. Any law respecting an establishment of religion. - whatever establishes a distinction against one class or sect is, to the extent to which the distinction operates unfavorably, a persecution. The extent of the discrimination is not material to the principle; it is enough that it creates an inequality of right or privilege.

2. Compulsory support, by taxation or otherwise, of religious instruction. . .

3. Compulsory attendance upon religious worship. Whoever is not led by choice or a sense of duty to attend upon the ordinances of religion is not to be compelled to do so by the state.

4. Restraints upon the free exercise of religion according to the dictates of the conscience. - But 'religious liberty does not include the right to introduce and carry out every scheme or purpose which persons see fit to claim as a part of their religious system. No one can stretch this liberty so as to interfere with that of his neighbor, or violate police regulations or the penal laws of the land enacted for the good order and general welfare of all the people."

5. Restraints upon the expression of religious belief. An earnest believer usually regards it as his duty to propagate his opinions, and to bring others to his views. To deprive him of this right is to take from him the power to perform what he considers a most sacred obligation. 48

of the above listed conditions which no authority had the right to abridge, numbers (4) and (5) seem to be the most important

47 Thomas M. Cooley, Constitutional Limitations (8th Ed., Boston: Little, Brown, and Co., I927) II, p. 966.

48 Ibid., pp. 966-969. 
49

in the application of constitutional tradition by the supreme Court in cases involving the Witnesses. But tradition alone is not sufficient to warrant cunstitutional decisions on which hinge the fate of unpopular groups, and the hope of free democratic institutions. The controversy occurring on the bench in many of these cases, cogently attests to that fact.

It seems in a way strange, that a religious group whose basic doctrines oppose any form of organized government, would call upon the government to protect its doctrines which if affected to their logical conclusion would only serve to destroy the government affording the protection. This is in part due to the zeal with which the Jehovah's Witnesses prosecute their beliefs; it is not, obviously, a judicial question. Despite their increased activity in recent years to propagate a religious faith, whenever the opportunity presented itself, "in spite of their doctrinal repudiation of earthly governments they have not hesitated to appeal to the courts."49 one writer expresses his impatience in this fashion; "the witnesses are a litigious body, and appeal every adverse court decision to a higher tribunal." 50

The very essence of any fundamental freedom requires a tolerance of activities which may be adverse to the main

\footnotetext{
49waite, Minnesota Law Review, XXVIII, p. 223.

50 Willard I. Sperry, Religion in America (New York:
} Macmillan Co., 1948), p. 101 . 
stream of any free society. With this percept in mind $\mathrm{Mr}$. Justice Jackson remarked -- concerning the activity of a strange cult known as the "I am" movement -. "We must put up with, and even pay for, a good deal of rubbish." 51 The Jehovah's Witnesses too may be included in "a good deal of rubbish" -- depending on the point of view -- but an adverse court decision cannot be based on such subjective conclusions, because "religion is not a term of precise content. Its meaning for some is anything but religious for others." 52 Hence, "whether one accepts their teachings or he privately thinks them ridiculous, is beside the point." 53 To Carl J. Friedrich, freedom of religion is a "more baffling problem" than the problems involved in the other freedoms, for "here, the difficulties are political and spiritual. . The positive acceptance of other men's beliefs is difficult in inverse proportion to the ardor with which a particular faith is held to be 'the truth." 54 According to this formula, the court could not expect to handle a more difficult religious or constitutional

5l United States v. Ballard, 322 U.S. 78 (1944), p. 95. Justice Jackson felt the determination as to whether respondents actually believed their claims was "precisely what the court put beyond the reach of the prosecutor." p. 95.

52 Wallace Mendelson, The Constitution and the Supreme Court (New York: Dodd, Mead and Co., Inc., I959), $\frac{\text { p. }}{432 .}$

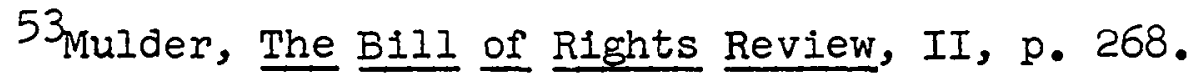

${ }^{54}$ Carl J. Friedrich, "Rights, Liberties, Freedoms," University of Pennsylvania Law Review, XCI (Dec., 1942), p. 316. 
51

problem than that presented by the Jehovah's Witnesses.

The laws of this country which grant special favors to the clergy, 55 have not alleviated the difficulties of the Court in dealing with these religious zealots.

In recent years courts in many states have been flooded with litigation involving the issue of religious freedom particularly as applied to that sect known as Jehovah's Witnesses whose disciples contend that they, as ordained ministers, cannot be subjected to civil regulations in carrying out their ministries. 56

For this and other reasons, there has been "a long list of Supreme Court decisions concerning the right of Witnesses, every one of which contains some instance of governmental activity." 57

55This practice is in accordance with the Judaeo-Christian tradition. In the old Testament, Levi, one of the twelve sons of Jacob, was head of the priestly line whose sustenance was provided by the people. Thus the tribe of Levi was accorded special privileges, and served as religious leaders. This tradition can be seen in the suffrage qualifications of the American Colonies, whereby the clergy, by virtue of its special dispensation, could exercise the voting privilege without meeting certain requirements prescribed for the rest of the citizenry. Under the current scheme of the taxing structure, the clergy enjoys certain benefits not accorded to those pursuing secular occupations. The exemption permitted ministers for housing benefits is an example of this special privilege. Thus even in the modern day, there is a carry-over of the ancient practice of favoring the men of the cloth.

56 "Civil Liberties -- Enforcement of Peddler's Licensing Ordinance Against Members of Religious Sect Engaged in Distribution of Pamphlets," Loyola Law Review, I (June, 1942), p. 229.

57carr, Federal Protection of Civil Rights, p. 15. For a discussion of the persistence of the Jehovah's witnesses before the Courts, see also: Wesley Mccune, The Nine Young Men (New York: Harper and Brothers, 1947), pp. 143-144; C. Herman 
Much has been said by many regarding the flood of cases instituted before the Courts by the Jehovah's Witnesses. To be sure, they hoped to be the direct beneficiaries of the huge amount of litigation brought before the tribunals, but they served at least another purpose.

The Jehovah's Witnesses who became involved in trouble with the law were only seeking to propagate their unpopular creed. But they furnished to the Supreme Court its most fruitful opportunities. . to strike down arbitrary restraints upon the freedoms guaranteed by the First Amendment. It should be emphasized, furthermore, that the impact of the Jehovah's Witnesses' decisions of the high tribunal is not confined to those using speech as a means of evangelism. For this is one of the areas where there is a close interrelation between freedom of speech and of religion. Regulation used to block religious evangelism today may be employed to stifle political expression or speech tomorrow. 58

Despite the fact that the Court has been generally favorable to the pleadings of the witnesses, and to religious liberty in general, it has not been free from vigorous

Pritchett, The Roosevelt Court: A Study in Judicial Politics and Values (New York: Macmillan $\bar{C} 0$, 1948), pp. 30-31; David Filman, The Limits of Freedom (New Brunswick: Rutgers Univ. Press, 1959,, p. 27; Alfred H. Kelly and Winfred A. Harbison, The American Constitution Its Origins and Development (New York: W.W. Norton and Co., Inc., 1955), pp. 803-805, and Illinois Law Review of Northwestern University, XXXV(May, 1940), pp. 90-95. For a more general treatment, see: Chapter XIV, Alpheus T. Mason, and William M. Beany, The Supreme Court in a Free Soclety (Englewood Cliffs: Prentice Hall Inc., 1959), pp. 285-304.

58 Bernard Schwartz, The Supreme Court: Constitutional Revolution in Retrospect (New York: The Ronald Press Co., I957), p. 24I. 
53

criticism. The Witnesses too have criticized the Court's decision whenever the decision was contrary to their pleadings (which has not been frequent). But this is proof of the existence of a healthy political freedom.

Reading some of the remarks made by Nathan $\mathrm{H}$. Knorr, the President of the Society, which have impugned the actions and the motives of such federal branches as the supreme Court, one is forced to remark what a basically sound country we have here to absorb such criticism. Actually, that fact itself seems to belie most of the accusations.59

The Chief Legal Counsel for the Witnesses, Hayden Cooper Covington, "who in his way has probably contributed as much to the development of the constitutional law relating to civil liberties as any man in American history, "60 accused the court of being "not liberal toward liberty."6I To the constituency he cautioned, "To try to know what the next move of the court will be is like trying to tell when and where lightning is going to strike, from now on just brace yourselves for anything."62 As if to prove his coint, Mr. Covington, as the chief counsel for the Jehovah's Witnesses before the Supreme court, "tried again, and again, and yet again."63

59 "Jehovah's Witnesses," New York Times, July 25, 1953, p. 10 .

${ }^{60}$ Leo Pfeffer, Church, State and Freedom (Boston: Beacon Press, 1953), p. 519 .

$61_{\text {New }}$ York Times, July 24, 1953, p. 13.

62 Ibid.

${ }^{63}$ Pfeffer, Church, State and Freedom, p. 519. 
When Justice Sanford in the Gitlow case, casually remarked that the freedom of speech and press contained in the First Amendment were "protected by the due process clause of the Fourteenth Amendment from impairment by the states, "64 he provided a key to the gate through which a large stream of civil liberties cases would flow, but not without the pangs of growth and legal congestion in commerce. To other individuals and groups as well, but more so to the Jehovah's Witnesses, the way was paved for legal action by the time the first Jehovah's Witnesses case reached the High Court. The declaration by the Court that states may not abridge First Amendment guarantees, clearly permitted "a man [to] subscribe to whatever religious beliefs he may desire, and even... to translate these beliefs into concrete acts." 65 Not only did Gitlow and its counterparts afford certain activities from state interference, the Supreme court itself was given a new role. "The supreme court in its modern role is a fascinating subject for observation. It operates at the storm center of our national life, it manifests the lofiness of our constitutional ideals." 66 Thus if constitutional principles are not always clear-cut in this development, one thing remains

64 Gitlow v. New York.

65 Herbert Wright, "Religious Liberty Under the Constitution of the United States," Virginia Law Review, XXVII (Nov., 1940), p. 87 .

${ }^{66}$ Carl B. Swisher, The Supreme Court in Modern Role

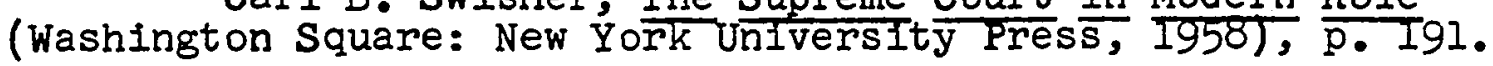


55

unquestionable; that is, the work load of the supreme court has been constantly on the increase.

The discussion of this chapter has centered mainly on the "new liberty" which came into judicial vogue since the Court took that view beginning around 1925.67 As it has already been noted, only three years prior, the court in the Prudential Insurance Company case 68 had held that the Fourteenth Amendment did not make the protections of the First Amendment binding on states. As time went on however, "every aspect of First Amendment freedoms was made available against the states under [the] incorporationist's philosophy. Religion, speech, press, assembly and petition were given protection against state action violative of the First Amendment."69 Occasionally however, some justices have suggested that freedom of speech and of the press may be secured in greater proportion under the Pirst Amendment than under the Fourteenth Amendment, 70 but the court has never adopted this view. As to when, if ever, other guarantees in the Bill of Rights will be incorporated into the meaning of the Fourteenth Amendment is an academic question,

67 It is generally agreed that the Gitlow case marked the beginning of the "new liberty."

68259 U.S. 530 (1922).

69Dumbauld, The Bill of Rights and what it Means Today, pp. $133-134$.

70Beauharnais v. Illinols, 343 U.S. 250 (1952), and Roth v. United States, 354 U.S. 475 (1957). 
56

and is not within the purview of this study, but the fact that the Court has accepted the incorporation doctrine regarding First Amendment freedoms is a sine qua non to this examination. 


\section{PART II}

THE COURT, THE CONSTITUTION, AND THE CULT

\section{CHAPTER III}

\section{SOLICITATION AND STATE ORDINANCES}

The first case involving Jehovah's Witnesses brought before the United States Supreme Court was in February of 1938, I when Alma Lovell, a member of the sect, was convicted by a Recorder's Court of the City of Griffin, Georgia, for violation of a city ordinance. This marked the beginning of a long list of Supreme Court cases affecting this minority religious group. The failure of the appeliant to acquire a permit for distribution of literature as prescribed by the city ordinance resulted in her conviction. The supreme court took the case on appeal after the Georgia courts refused review.

The violation, which is not denied, consisted of the distribution without the required permission of a pamphlet and magazine in the nature of religious tracts, setting forth the gospel of the 'Kingdom of Jehovah.' Appellant did not apply for a permit, as she regarded herself as sent by Jehovah to do 'His work' and that such an application would have been 'an act of disobedience to His command. ${ }^{2}$

The contention by the appellant was that the ordinance

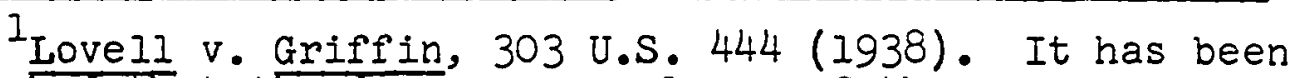
established that the due process clause of the Fourteenth Amendment incorporates the First Amendment freedoms to the extent that states may not abridge the guarantees.

${ }^{2}$ Ibid., p. 448 . 
violated the guarantees of religion and press as accorded by the First Amendment which are safeguarded by the application of the due process clause of the Fourteenth Amendment. The city ordinance requiring permits for the distribution of literature, was not instituted without reason. Such things as misuse and littering of streets, disturbance of public order, molestation of the inhabitants are proper police measures which the states have the right to regulate.

Efforts to prevent such disturbance without directly imposing restraint upon the free exercise of religious beliefs, have led to the enactment of statutes and ordinances seeking to regulate the distribution and sale of 'religious' literature. Many of these have been successfully challenged on constitutional grounds. But the most common among them, the 'handbill' or 'peddler's' ordinance requiring the procurement or purchase of a license or permit by the vendor or distributor, has been sustained. The purpose of such legislation is generally said to be either that of preventing the littering of public highways with advertising circulars, or to assure the safety and convenience in the use of the streets. 3

The Court did not ignore the power of the states regarding matters of public order and convenience, but the ordinance in the instant case was too broad for "it covers every sort of circulation either by hand or otherwise." 4 The law went too far in that "it forbade every sort of distribution except such

${ }^{3}$ Julius H. Miner, "Religion and the Law," Chicago-Kent Law Review, XXI (March 1943), pp. 165-166.

${ }^{4}$ Lovell v. Griffin, p. 45 I. 
as the city manager saw fit to allow." 59 The court was genuinely concerned over the "broad sweep" and the "indefiniteness" of the ordinance, the all-inclusive nature of "Iiterature," the lack of restriction as to the application of the law regarding time or place, and the fact that the city manager was "clothed with arbitrary power." 6 Delivering the opinion of a unanimous Court, Mr. Chief Justice Hughes declared:

We think that the ordinance is invalid on its face. Whatever the motive which induced its adoption, its character is such that it strikes at the very foundation of the freedom of the press by subjecting it to license and censorship. 7

Freedom of the press is not confined to newspapers and periodicals, it embraces pamphlets and leaflets said the Chief Justice. While the freedom from previous restraint ${ }^{8}$ is not absolute, the prevention of this restraint was a leading purpose in the adoption of this amendment. "Legislation of the type of the ordinance in question would restore the system of license and censorship in its baldest form." 9 According to Zechariah Chafee, "previous restraint on speech exists whenever a license for any method of communicating thought depends

5Rotnem, A.P.S.R., CIX, p. 1057.

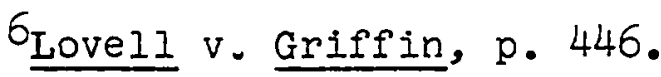

7 Ibid.

${ }^{8}$ See Near v. Minnesota, and Grosjean v. American Press.

${ }^{9}$ Lovell v. Griffin, p. 452 . 
on somebody's judgment. So the problem always arises even with a general permit law."10

The Jehovah's Witnesses, in presenting their first case before the high tribunal, were successful in "proving" their point, and obtaining from the court of clearer definition of certain guarantees. The method invoked by the witnesses was not novel; but the approach displayed wisdom.

The constitutionality of legislation of this nature has been challenged, orincipally by religious group as abridging freedom of the press and of religious worship. When so challenging, such groups apply terms such as 'previous restraint,' 'too broad,' 'censorship,' 'Ilcense,' 'aiscrimination, ' 'vagueness,' 'lack of authority,' and the like.11

The Court's interpretation that the press "comprehends every sort of publication which affords a vehicle of information and opinion,"l2 meant that all religious literature could come under the same classification, thereby being entitled to the same privileges. This, of course, did not mean that municipalities had no control over distribution of literature, it does mean however, that a city may not pass an ordinance that "strikes at the very foundation of the freedom of the press by subjecting

10Zechariah Chafee, Jr., Free Speech in the United

States (Cambridge: Harvard University Press, I942), p. 400 .

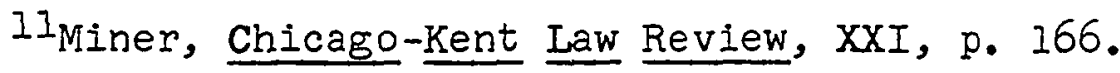
12 Lovell v. Griffin, p. 451. 
it to license or censorship." 613 Furthermore:

Cities may have a duty to keep their streets clean and free from obstruction, but as a means of doing so they may not forbid a person rightfully on the streets from handing literature to one willing to receive it. The streets are natural and proper places for the dissemination of information and opinion. The public convenience of clean streets does not justify a regulation which deprives citizens of this constitutional right. 14

As an administrative measure, the court also made clear that anyone who is prosecuted for disobeying a license ordinance which is void on its face may contest its validity without having sought a permit under it. 15 If this were not so, Amy Lovell would have difficulty in praying the High Court for an appeal. Whether the next case was planned by the "victors" or not, it came within a year after the Lovell case. Evidently the Lovell decision, significant though it may have been, "by no means put an end to attempts by municipalities to censor distribution of "literature on the streets." 16 Actually, four similar cases were disposed of simultaneously by the supreme Court in Schneider v. State (Town of Irvington). 17 The

\section{Ibid.}

14 Robert E. Cushman, "Constitutional Law in 1939-1940," A.P.S.R., XXXV (April, 1941), p. 268.

15smith V. Cahoon, 283 U.S. 553 (1931).

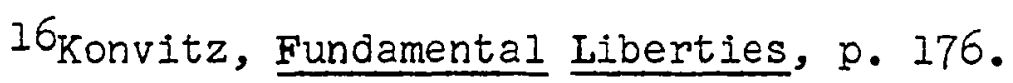
Irvington.

17308 U.S. 147 (1938), hereafter cited as Schneider v. 
62

subject cases dealt with ordinances of the Cities of Los Angeles, California; Milwaukee, Wisconsin; Worcester, Massachusetts; and Irvington, New Jersey. All the ordinances were similar in that they required -- through various procedures -- a permit for the distribution of literature. The Irvington ordinance appeared most burdensome in that it required the applicant to be fingerprinted and photographed before the permit could issue from the Chief of Police. Moreover the applicant had to furnish detailed information about himself and the project for which he was canvassing. The Chlef of Police had discretion over the moral character of the applicant in issuing the permit. The petitioner in the instant case, a member of the watchtower Bible and Tract Society, and as such a certified member of the Jehovah's Witnesses, was arrested and charged with canvassing without a permit. As in the case of Amy Lovell supra, the appellant did not apply for a permit because to do so would be a disobedience to the command of God.

The Recorder's Court of New Jersey convicted her and both the Court of Errors and Appeals and the State Supreme Court upheld the conviction. The state courts distinguished Lovell v. Griffin 18 on several grounos; but mainly on the ground that the ordinance in this case specified the places in which distribution without a permit was prohibited. The 
63

state also contended that the Lovell decision was not controlling since the ordinance there was not manifestly aimed at prevention of littering of the streets. Thus,

Attempts were made by the proponents of the ordinance in the principle case to distinguish them from the unconstitutional ordinance in Lovell v. Griffin. There, distribution was forbidden everywhere, while in the instant case only specified public places were stipulated in which distribution was forbidden. Also the Griffin ordinance was not primarily directed at preventing the littering of the city streets. 19

The State further contended that the time for canvassing was prescribed from 9 A.M. to 5 P.M., a stipulation which was neither vague nor sweeping.

In striking down the statute, the court did not deviate substantially from the Lovell decision. Mr. Justice Roberts spoke for the majority.

Although a municipality may enact regulations in the interest of public safety, health, welfare or convenience, these may not abridge the individual liberties securso by the Constitution to those who wish to speak, write, print or circulate information or opinion. 20

Roberts was quick to point out however, that this right was subject to regulation of conduct which in all instances should be reasonable. For example, this liberty could not be exercised

IPWilliam Aull III, "Freedom of Speech and Press -Handbill Ordinances," Missouri Law Review VI (Jan., 1941), pp. 103-104.

${ }^{20}$ Schneider v. Irvington, p. 160 . 
64

by standing in the middle of the street, contrary to traffic regulations, or compelling passer-bys to take the leaflets and handbills by forming a cordon as a means of stopping pedestrians. Prohibitions by the state of such conduct would not abridge constitutional liberties "since such activity bears no necessary relationship to the freedom to speak, write, print or distribute information or opinion."2I The content of the language of the court, in places, was actually no different from Chief Justice Hughes' pronouncements in the Lovell case, as for example, "to keep the streets clean and of good appearance is insufficient to justify [such an] ordinance;" "the streets are natural and proper places for the dissemination of information and opinion; "and the most grandiloquent but meaningful phrase of all, "To require a censorship through license which makes impossible the free and unhampered distribution of pamphlets strikes at the very heart of the constitutional guarantees."22 There seems to be no marked difference between the ordinances involved in both the Lovell and the Schneider cases except in the matter of degree. The Court however, in the latter case reiterated a general rule. "In every case, therfore, where legislative abridgment of the inghts is asserted, the courts should be astute to examine the effect of the challenged legislation."23 This

$$
\begin{aligned}
& 21 \text { Ibid. } \\
& 22 \text { Ibid., p. } 164 . \\
& 23 \text { Ibid., p. } 161 .
\end{aligned}
$$


65

meant, as cases arose, the delicate and difficult task of weighing the circumstances and appraising the substantiability of the reasons advanced in support of the regulation of the free enjoyment of rights fell upon the courts. ${ }^{24}$ The Supreme court does not take pleasure in handing these cases -- it seems -- but "it may be suggested that the LovelI and Schneider cases indicate no more than the reluctance to decide a question until it has to be decided, which usually is the part of wisdom." 25

In both cases, much was said about the littering of public streets, the control of which was the state's prerogative. The Schneider decision regarding this matter can be differentiated from Lovell in that the court said "There are obvious methods of preventing littering. Amongst these is the punishment of those who actually throw papers on the streets."26 This declaration on its face appears to sanction the activity of distributing literature in the broadest terms. And so it does:

However, there is nothing in the decision of this court to indicate a municipality may not license the circulation of advertising matter where such distribution is for the purpose of private

${ }^{24}$ Ibid. This reasoning left the door open for the Court to handle each case according to its merits although the facts involved may be identical. p. 520 .

25 Green, Washington University Law Quarterly, XXVII, 26 Sihneider v. Irvington, p. 162 . 
65

profit. Nor does the guarantee of freedom of speech deprive the city of power to enact regulations against throwing literature broadcast into the street. The thing declared unconstitutional is the absolute bar on distribution of handbills as a means of preventing littering of public streets. 27

The Court was not intent upon restricting the states from carrying out enforcement measures as it was determined to protect the rights of free speech. The Milwaukee ordinance, it was contended could be invoked upon the distributor only if those who receive the literature threw it in the streets. To this contention the Court's answer was that "The ordinance cannot be enforced without unconstitutionally abridging the liberty of free speech."28 In other words before the ordinance could be validly enforced, the distributor nimself must throw the literature in the streets! The fact that the recipient of the Iiterature threw it in the street is not a valid reason for the curtailment of its distribution. This is what the court was talking about in both cases when it said -- in effect -the purpose of keeping the streets clean is insuficicient to justify an ordinance which prohibits a person from distributing literature. A student of civil liberties from Norway, in his observation of Schneider decision, remarked:

The Supreme Court regarded this disposition as

27 Aull, Missouri Law Review, VI, p. 105. ${ }^{28}$ Schneider v. Irvington, p. 163. 
67

amounting to censorship and therefore unconstitutional. The streets are natural and proper places for the dissemination of information and opinion; and one is not to have the exercise of one's liberty of expression in appropriate places abridged on the plea that it may be exercised in some other place. Here it was religious writings that were in question; but the result would have been no different had they had political contents. 29

The meaning of distribution overlaps into both the areas of speech and press, and was so held by the court. The argument that the prevention of distribution does not affect freedom of the press has been discountenanced by the supreme Court's declaration that liberty of circulation is as essential as freedom of publishing. 30 Unquestionably, "without the right to circulate, the publication would be of little benefit to the publisher."3I Thus the essential nature of distribution as being part of the basic guararivees secured by the First Amendment was established long before Jehovah's Witnesses brought their cases before the Supreme court.

Although the two cases herein discussed, involved a religious group and its attempt to spread its religious beliefs, the court did not consider the question of religious freedom. "The court held that the ordinance was a deprivation of freedom

29Frede Castberg, Freedom of Speech in the West a Comparative Study of Public Law in France The United States and Germany, Tos10: OsIo Univ. Press, 1960), p. 146.

30Ex Parte Jackson, 96 U.S. 727, (1878).

31 Aull, Missouri Law Review, VI, p. 103. 
68

of speech and of the press, but said nothing with regard to the invasion of religious liberty." 32 It was not until 1940,33 that the court considered, in another case affecting the Jehovah's Witnesses the essential nature of religious freedom in relation to municipal ordinances.

During the period of February 12, 1943 and March 8, 1943, the Supreme Court heard and disposed of two cases 34 affecting Jehovah's Witnesses not unlike the two cases discussed above. In distinguishing from Lovell and Schneider these two cases involved the solicitation of funds, a practice which the court did not deem very important to the constitutional issue. The similarities of the two cases are striking. Both cases: (I) were prosecuted in municipalities (Dallas and Paris respectively) of the state of Texas; (2) were handled by the supreme Court because under state law, the decision of the county court was not reviewable; (3) convicted at the state level, members of the watchtower Bible and Tract Society for distribution of handbills and leaflets which were included as "commercial advertising of books which the distributor is offering for sale;"35 (4) were decided by a unanimous supreme p. $518 .{ }^{32}$ Green, Washington University Law Quarterly, XXVII, 33cantwell v. Connecticut, 310 U.S. 296 (1940). Discussed in one of the following chapters.

${ }^{34}$ Jamison V. Texas, 318 U.S. 413 (1943), and Largent v. Texas, 318 U.s. 418 (1943). ${ }^{35}$ Jamison v. Texas, p. 415. 
69

Court, with the exception of Mr. Justice Rutledge who was appointed only a month before, and took no part.

In the Jamison case, Mr. Justice Black who delivered the opinion said that although the states may regulate the distribution of commercial leaflets,

They may not prohibit the distribution of handbills in the pursuit of a clearly religious activity merely because the handbills invite the purchase of books for the improved understanding of the religion or because the handbills seek in a lawful fashion to promote the raising of funds for religious purposes. 36

Furthermore, the Justice pointed out that the book described by the leaflets would be delivered to the home uoon payment of $25 \phi$ a sum considrably less than the actual cost. There were at least two considerations governing this aspect of the Court's decision. First, there was no actual profit in the sale; secondly, the court seemed to indicate that even if the sale were profitable, materials of a clearly religious nature promoted in a reasonable manner cannot be subjected to the same restrictions as other commercial products.

The state in the Jamison case, relying on the precedent set by Davis v. Massachusetts, 37 which declared in part, "no person shall, in or upon any of the public grounos, make any public address," etc., "except in accordance with a permit of the Mayor," contended that its power over the streets was

$$
\begin{aligned}
& 36 \text { Ibid., p. } 417 . \\
& 37_{167} \text { U.S. } 43 \text { (1897). }
\end{aligned}
$$


70

unlimited. To this the majority cited the decisions of the Court in later cases, two of which were the Lovell and Schneider, opinions. As if to add insult to injury, the Court continued; "In Schneider v. Irvington, we held that the city of Irvington might not forbid conduct almost precisely the same as that with which the appellant in the instant case is charged." 38

Justice Reed delivering the majority opinion in the Largent case thought it unnecessary to determine whether the distribution of the publications in question were sales or contribution. This was settled in the Jamison case. But Justice Reed felt compelied to reiterate that if dissemination of ideas would be dependent upon the approval of an official, "This is administrative censorship in an extreme form. It abridges the freedom of religion, of the press and speech guaranteed by the Fourteenth Amendment." 39 It is noteworthy that by this time, the incorporation of First Amendment freedoms into the due process clause of the Fourteenth Amendment was accepted to the extent that the first Amendment is not even mentioned in the discussion of these rights.

The Largent case differed from the Jamison case in this respect; the distributor was carrying on her activity in a residential area. The Court however, did not deem this

\section{Jamison v. Texas, p. 416. 39 Largent v. Texas, p. 422.}


distinction significantly related to the constitutional question for the decision it rendered was based on the exercise of basic rights rather than the time, place or manner by which these rights may be performed.

In the same year of the Jamison and Largent cases, the Supreme Court heard other cases involving the Jehovah's Witnesses, one of which was Martin v. City of Struthers (Ohio). 40 Once again Mr. Justice Black delivered the majority opinion, this time against three dissents by Justices Reed, Roberts and Jackson. The case was brought up to the high Federal Court on appeal from the Supreme Court of Ohio which upheld the conviction of members of the Witnesses for a violation of a city ordinance which prohibited door-to-door canvassing. The ordinance made it unlawfuI for any person distributing handbills or circulars or other advertisements to ring doorbells, knock on doors, or otherwise summon the occupants.

Mr. Justice Black noted that "for centuries it has been a common practice in this and other countries for persons not specifically invited, to go from home to home and knock on doors or ring doorbells to communicate ideas to the occupants or to invite them to political, religious, or other kinds of public meetings." 41 whether such visiting were permissible, Black thought each master of the household should determine,

$$
\begin{aligned}
& 40319 \text { U.S. } 141 \text { (1943). } \\
& \text { 4IIbid., p. } 141 .
\end{aligned}
$$


and not the community.

Because the City of Struthers, Ohio, was an industrial town engaged in the iron and steel business, many of its inhabitants were directly connected with the factories whose hours were staggered into different shifts. The division on the court seemed to be based quite significantly on this fact. The freedom to distribute literature poses a unique problem when the distributor happens to knock on the door of a person whose rest can be had only during the day. Furthermore, the respondents contended that the ordinance was directed against burglars who often pose as canvassers in order that they may have a pretense to discover whether the house is empty and "ripe for burglary." The court however rejected this contention by saying:

While door-to-door distributors of literature may be either a nuisance or a blind for criminal activities, they may also be useful members of a society engaged in the dissemination of ideas in accordance with the best tradition of free discussion. The widespread use of this method of communication by many groups espousing various causes attests its major importance. 42

To Mr. Justice Black, the ordinance seemed especlally odious in that "door-to-door distribution of circulars is essential to the poorly financed causes of little people." $43 \mathrm{Mr}$. Justice Reed, dissenting, naturally felt that here there was no

$$
\begin{aligned}
& 42 \text { Ibid., p. } 145 . \\
& 43 \text { Ibid., p. } 146 .
\end{aligned}
$$


such suppression; no censorship at all. "I do not read the ordinance as prohibiting the distribution of literature, "44 said Reed. "If the ordinance did prohibit the distribution of literature, while permitting all other canvassing, I should believe such an ordinance discriminatory," but, he added, "this ordinance is different."45 Mr. Mendelson has noted, "Struthers, perhaps, may be an extreme case in the sense that Dennis [v. United States, 339 U.S. 162 (1950)/ was extreme. In each as legislative authority saw it, an extravagant claim of aggressive individual right collided with a relatively more important community interest." 46 Whatever the cause or the extent of difficulty presented by the issue in question, "The decision in Martin v. City of Struthers extends the protective shleld of the due process clause to activities beyond a point deemed by a vigorous minority of the Court essential to the proper exercise of freedom." 47

${ }^{44}$ Ibid., pp. 155-156. See dissenting opinion.

45 Ibid., p. 156. Justice Reed felt that the ordinance was "a fair adjustment of the privilege of distributors and the rights of householders." This argument of "balancing interests" was upheld in Breard v. Alexandria, 341, U.S. 622, (1951), which involved magazine salesmen. The court in this case upheld the right of a community to control "obnoxious" house-to-house canvassing by ordinance. Magazines, it seems, could be sold by other ways. Black and Douglas, dissenting, thought this was an infringment of the liberty of press.

46 Wallace Mendelson, Justices Black and Frankfurter: Conflict in the court (ChIcago: UnIv. Of ChIcago Press, 1961), p. 62.

47 "Fourteenth Amendment -- Freedor of Press and religion," Minnesota Law Review, XXVIII, No.2 (Jan. 1944), p. 134. 
Mr. Justice Murphy's concurring majority opinion dealt mainly with the historical practice of house-to-house methods of preaching, and the ability of a householder who does not desire to have visitors to make known his wishes in a suitable fashion. It is not for the state to prohibit callers, responsibility lies with the occupant of the home said the Justice. Reed's dissenting opinion pointed out that no right is absolute, "once the door is opened, the visitor may not insert a foot and insist on a hearing. He certainly may not enter the home. To knock or ring, however, comes close to such invasions." 48

In the final analysis, the decision of the court seems to have been conditioned by the criminal aspect of the ordinance. It made the distributor punishable for a criminal act, even if the recipient were in fact glad to receive the distributor's material. In Frankfurter's words, "the ordinance before us merely penalizes the distribution of 'Iiterature." 149 The decision given in the instant case was not very well received. Even to some of those favoring a broad scope of interpretation afforded civil rights measures were somewhat

48 Martin v. Struthers, p. 157.

49 Ibid., p. 153. Frankfurter joined the minority with certain reservations. His chief concern seems to have been with the construction of the ordinance. He warned the majority that certain "controling" constitutional principles were left untouched. He sald that the "greatest leeway must be given to legislative judgment, "and "we should not, however unwittingly, slip into the judgment seat of legislatures." p. 154 . 
perturbed:

In the case of Martin v. Struthers the Supreme Court decided that it was unconstitutional to forbid knocking on the door or ringing the doorbell of a residence in order to deliver a handbill. Prevention of crime and assuring privacy in an industrial community where many worked on night shifts and had to obtain their sleep during the day, were held insufficient to justify the ordinance in the case of handbills, distributed in behalf of Jehovah's Witnesses. . . .IT IS QUITE STRIKING HOW FAR THE SUPREME COURT HAS BEEN ABLE TO GO IN ITS PROTECTION OF THE INDIVIDUAL'S RIGHT TO ENGAGE IN PROPAGANDA FOR HIS OPINIONS. 50

By way of contrast to the Struthers case, Prince v. Massachusetts 51 "illustrates the successful application of state criminal law against a religious defense."52 The case was brought before the Supreme Court on appeal after the highest court of Massachusetts had convicted Sarah Prince for violation of State Child Labor Laws. Massachusetts law made it unlawful for boys under twelve and girls under eighteen to sell newspapers, magazines, perlodicals, or bocklets in any street or public place. And whosoever knowingly engaged a minor to sell such articles was also guilty of said crime. Mrs. Prince was the guardian of a nine-year-old girl,Betty Simmons, who had persuaded her guardian to let her sell religious pamphlets on the streets. Both were members of the Italics supplied.

50 Castberg, Freedom of Speech in the West, pp. 323-233. $51_{321}$ U.S. 158 (1944).

52 Pritchett, The American Constitution, p. 473. 
76

Watchtower Bible and Tract Soclety, therefore were ordained ministers of God. Betty actually "believed it was her religlous duty to perform this work and fallure would bring condemnation 'to everlasting destruction at Armageddon." "53

Speaking for the majority, against the dissents of Murphy, Jackson, Roberts anc Frankfurter, Just1ce Rutledge acknowledged that "To make accommodation between these freedoms and an exercise of state authority always is delicate." 54 In basing his decision on police powers consideration, Justice Rutledge discussed at some length the public interest as against a claim of religlous liberty. He noted that "neither rights of religion nor rights of parenthood are beyond limitation." 55 Somewhat reminiscent of the "Brandeis Brief," 56 Rutledge elaborated on the possibility of social evils which may result from youth whose physical well-being is not properly

$$
\begin{aligned}
& 53 \text { Prince v. Massachusetts, p. } 163 . \\
& 54 \text { Ibid., p. } 165 . \\
& 55 \text { Ibid., p. } 166 .
\end{aligned}
$$

56see Mulier v. Oregon, 208 U.S. 412 (1908), which upheld hours legislation for women. The court acknowledged its debt to "the brief filed by Mr. Louis D. Brandeis" who was then counsel for the appellant. In effect the "Brandeis Brief," which constituted over a hundred pages was a detalled study of social ills. "The logic behind the brief rested upon the premise that if the Court in fact passed upon legislation of this kind in the light of its reasonable character and plausible relation to the social welfare, then the best possible approach was to overwhelm the justices with direct and specific documentary evidence as to the wisdom and intelligence of the law under review." From Kelly, The American Constitution, p. 526. 
cared for. The state has a wide range of power in affecting parental authority when the child's welfare is in question thought the Justice. Furthermore, he gave added meaning to constitutional law by saying that "the state's authority over children's activities is broader than over like actions of adults." 57 The state "has an interest in safeguarding its children and keeping them off the streets; and, in doing so, to that extent may restrict their freedom." 58

The appellant did not make her plea on the basis of freedom of the press regarding this as a secular right which the state had a right to control. Her contention was on two grounds; freedom of religion as guaranteed by the First Amendment and made applicable to the states by the Fourteenth, and equal protection as guaranteed specifically by the Fourteenth Amendment. As to the first contention the Court said religious liberty was not absolute. Furthermore, the statute in this case did not actually infringe religious liberty in that the public interest consideration out-balanced the relatively minor ccnsideration of permitting children on the streets to sell literature, an action which was detrimental to the child's health in the first place. As to the equal protection argument, the Court disposed of that question summarily by noting that

57 Prince v. Massachusetts, p. 168.

58 John L. Luvass, "Freedom of Press -- Freedom of Speech -- Right of Religious Sects to Distribute Literature," Oregon Law Review, XXI (December, 1941), p. 81. 
78

there was no denial of equal protection in excluding children of a particular sect from the use of public streets inasmuch as other children were similarly barred.

Mr. Justice Murphy's vigorous dissent has given cause for varied speculations.59 Regarding the health and moral welfare of the child, Murphy felt that the state falled to show substantially any reasonable evidence that such dangers existed. The dangers of truancy and ill-health if they existed at all "are thus exceedingly remote, to say the least."60 The dissent seems to indicate that in the case of the Jehovah's Witnesses especially, "The sidewalk, no less than the cathedral or the evangelist's tent, is a proper place, under the Constitution, for the orderly worship of God."6I In the historical context, because persecution against unpopular religious groups has been unduly harsh and brutal, Murphy warned; "We should therefore hesitate before approving the application of a statute that might be used as another instrument of oppression. "62 Unlike other Jehovain's Witnesses cases brought before

590ne of the recent studies reveals that Murphy, a Roman Catholic, rendered an "un-catholic" decision. This is especially interesting in view of the fact that the Jehovah's Witnesses' endeavor is vehemently directed against the Roman Catholic Church. See Harold W. Chase et. al., "Catholics on the Court," New Republic, CILIII (sept. 26, 1960), pp. 13-15. opinion.

${ }^{60}$ Prince v. Massachusetts, p. 175. See Dissenting

$6_{\text {Ib1d.., p.174. }}$

62 Ib1d., p. 176. 


\section{9}

the High Court, the Prince case presented and compelled a judgment ooncerning the conflict between a religious activity and the power of the state to regulate child labor. The court was cognizant of the "delicate" nature of the issue and based its judgment primarily on social considerations. Child-labor cases, not unlike the various aspects of religious activities, had undergone a long and arducus period of court litigation. 63 The clamor for governmental regulation over this "crippling enterprise" finally provoked the nation to action and a constitutional amendment was proposed. 64 When the Prince decision was rendered, the sentiment against child-labor conditions was at a high point. All this is not to say that constitutional decisions are based on popular sentiment. But on the other hand, no careful student of American constitutional law would claim that social considerations do not play a significant role in the determination of judicial judgments which affect the Interest and welfare of the public.

The cases examined in this chapter seem to support the rule that "laws which forbid outright or prohibit entirely door-to-door and street preaching and distribution of

63 The two most outstanding examples are: Hammer $v$. Dagenhart, 247 U.S. 251 (1918), and Bailey v. Drexel FurniEure Company, 259 U.S. 20 (1922). IE Is admitted that these cases are examples of federal control and are not completely relevant.

$64 \mathrm{~A}$ child-labor amendment was proposed in 1924 to give Congress the authority to regulate or prohibit child labor, but failed of ratification mainly because subsequent legisiation nullified the need for such an amendment. 
80
literature, "65 by religious groups, are invalid. The court will, however, permit reasonable regulation by states where such distribution works a hardship on individuals, for example minors, to the extent that their health and welfare may be jeopardized. This means that in some cases, the court was wllling to grant the right to states to exercise police power authority over certain civil liberties considerations, in order that there would be maintained a balance of certain interests over others with respect to the total effect on public policy.

65 Defending and Legally Establishing, the Good News, $p$. 43. In most of these cases the court made reference to Hague v. Committee for Industrial Organization, 307 U.S. 496 (1939), in which the court held unconstitutional and vold an ordinance which forbade any person to "distribute or cause to be distributed or strewn about in a street or public place any newspaper, periodical, book, magazine, circular, card comphlet." 


\section{CHAPTER IV \\ PERMITS, PARKS, AND PARADES}

In the United States, where the right to exercise and promote religious inclinations has never been seriously challenged or curtailed constitutionally ever since the birth of the Republic, outward displays and demonstrations of sectarian proclivities have been one of the arteries to the maintenance of liberty especially in recent years. For some groups, demonstrations in the form of parades and processions in order to inform the public, have been a useful media for the propagation of religious bellefs. Some examples are vacation church school campaigns, and preparations for coming evangelistic crusades. Under the Constitution, no one, least of all the Supreme court, would question the right of the various groups to conduct reasonable public appearances as a means to promote their beliefs, yet it is precisely on this issue the Jehovah's Witnesses have suffered several setbacks in their demand for unfettered freedom. There was, of course, good constitutional ground for curtailing certain activities.

The first case to reach the supreme court on the issue of public parades was Cox et. al. $v$. New Hampshire, ${ }^{l}$ in 1941. The appellants were five Jehovah's Witnesses who, with sixtythree others of the same persuasion, were convicted of

$$
1312 \text { U.S. } 569 \text { (1941). }
$$


82

violating a state statute for engaging in a public procession without a special license as prescribed by the statute. The statute made it unlawful to carry on a parade or a procession upon any public street or way,-without a special license granted by a licensing committee set up by the statute. The statute also imposed a fee ranging from fifty dollars to a maximum of three hundred dollars.

The appellants claimed that their rights of freedom of worship, freedom of speech and press, and freedom of assembly were denied. They also contended that the statute "vested unreasonable and unlimited arbitrary and discriminatory powers in the licensing authority, and was vague and indefinite."2 The Municipal Court of Manchester and higher state courts overruled the contentions, and the case was brought to the Supreme Court on appeal.

Mr. Chief Justice Hughes, speaking for a unanimous court rendered a decision which was a reprimand as much as it was fine prose on the principles of constitutional law. First, it was noted that the appellants, in their "information march," carried placards whose inscriptions were not all too pleasant (The Chief Justice did not say they were unpleasant, this is arrived by implication). Some of these signs read, "Religion is a Snare," "Pascism or Freedom. Hear Judge Rutherford and Face the Facts." The court pointed out that the statute in no 
83

way prevented the display of the placards, the regulation was against unlicensed "organized formations of perscils using the highways."3 Had these demonstrators travelled in unorganized fashion, not in a parade or procession, the statute would not have been violated; and the purpose of the demonstrators, would be met in that the circulation would have been just as large.

Any distribution of pamphlets or parading of signs would have been just as effective in terms of circulation, if carried on in unorganized fashion by Individual members. If this had been the case, the legislation in question would have had no application to the activities of segregated individuals. Inde ${ }^{\circ}$ it is this thought that strikes the decisive note regarding the validity of the regulatory provisions in question. 4

"Civil Liberties," It was noted by the Court, "as guaranteed by the constitution imply the existence of an organized society maintaining public order without which liberty itself would be lost in the excesses of unrestrained abuses. " 5 The authority of the state to regulate the activities on the streets to insure safety and convenience to the people is not consistent with civil liberties. "The control of travel on the streets of cities is the most familiar illustration of

\footnotetext{
3Ib1d., p. 575.

"'state Regulation of Street Processions," Bill of Rights Review I (Spring, 1941), p. 233.

5 Cox v. New Hampshire, p. 574 .
} 
this recognition of social need." 84 The requirement for the application of a permit had obvious advantages the most important of which was in giving the public authorities advance public notice so as to afford opportunity for proper policing. The state has the right to fix the time and place for processions in order to minimize inconvenience, confusion and disorder likely to arise in the streets.

The use of the highway is subject to state control. The public has no vested rights there in and any reasonable measure of restriction is proper. . - This notion is perhaps the invisible buttress bracing the entire argument of the defendents and yet it is ineffective here for although the right of speech is an incident of the right of highway travel, the right of highway travel is not inherent in the right of speech.7

The Chief Justice who gave the opinion in the Lovell case distinguished that decision on the basis that the statute in Lovell prohlbited the distribution of literature, thus striking at the very foundation of freedom of the press by subjecting it to censorship. For essentially the same reason, plus the fact that a police officer was given too much discretion, neither was the Schneider decision controlling in this case.

The Court distinguishes the Schneider, Cantwell

\section{Ibid.}

7Vincent J. Barry, "Statute Requiring Permit for Parade on Public Streets," Boston University Law Review XXI (June, 1941), pp. 541-542. 
and Hague cases on the ground that these decisions placed an arbitrary power of refusing the permit in a public officlal. Also distinguished from the instant case is that of Lovell $v$. Griffin, in which legislation prohibited all distribution of literature unless a license was first obtained. 8

The whole decision seems to hinge on the issue of regulating the traffic on public streets so as to permit an orderly flow of general activity in a city where during one day at least "26,000 persons passed one of the intersections where the defendants marched." 9

The Supreme Court opinion emphasizes the fact that the appellants were not prosecuted for distributing literature or otherwise conveying information; rather, the sole charge against the appellants was that they were taking part in a parade or procession on public streets without a permit as required by the statute.10

After declaring that the statute did not deny the appellants their freedom of religion, speech, press, or assembly, the Court answered the contention that the statute was "vague" and "indefinite." The licensing board, the court held "was not vested with arbitrary power or an unfettered discretion." Il The statute made it clear that there musi be uniformity of method of treatment, no uniair discrimination and a "systematic,

$8_{\text {B11l }}$ of Rights Review, I, p. 235.

${ }^{9}$ Cox v. New Hampshire, p. 573.

$10_{\text {Bill }}$ of Rights Review, I, p. 235.

${ }^{11}$ Cox v. New Hampshire, p. 576. 
86

consistent just order of treatment."12 To the court then, the statute was neither vague nor arbitrary, thus the contention by the appellants on this score was denied also.

The members of the Witnesses who were convicted under the statute, strange as it may seem, did not question the constitutionality of the license fees, but the Court proceeded to dispose of the question. The maximum of $\$ 50.00$ for license fees and $\$ 30.00$ for use of public facilities imposed by the statute, the court thought to be a "permissible range." The fee was "not a revenue tax but one to meet the expense incident to the administration of the Act and to the maintenance of public order in the matter licensed."13 As far as the court was concerned, the "flexibility" of the fee schedule was proof that the measure was not discriminatory. As a rule, the court has always upheld the imposition of fees by municipalities for the use of public facilities, provided that the fees were not revenue measures. "There is nothing contrary to the constitution in the charge of a fee limited to [meeting expenses.7"14

As in most cases affecting the public welfare, police powers loom large in the instant case. All that the statute required in this case was the application of a permit which under the conditions and the provisions of the statute could

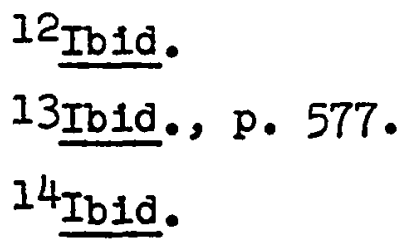

12 Ib1d.

13I01d., p. 577.

14 Ibid. 
87

not have been denied. The court felt that the application for a permit would have helped the appellants in their endeavor. While such reasoning had no significant bearing on the Court's decision, public welfare and order did. "The scope of religion is thus limited by the principle that the practice of religion may be made to conform to generally prevaliing conceptions of the general safety, morals, and welfare."15 The opinion, in this case;
recognizes the right of the state, in controlling the use of its public streets for parades, to take into consideration the time, place and the manner of the demanded use in relation to other proper uses of the streets. Hence a system in- tended to give effect to that public interest cannot be held a denial of freedom of religion and speech, provided no unfair discrimination is practiced in its operation. 16

In contrast to the Cox case, in Niemotko v. Maryland, 17 a unanimous Court struck down the action of a municipality (Havre de Grace, Maryland), in its attempt to regulate activities in a public park on the ground that there was rank discrimination. Niemotko and Kellyl8 both members of the

15 Henry Rottschaefer, Handbook of American Constitutional law (st. Paul: West Publishing Co., 1939), p. (27. 16 Waite, Minnesota Law Review, XXVIII, p. 229. 17340 U.S. 368 (1951).

18 The Instant case was heard together by the supreme Court with KeIly v. Maryland, an appeal from the same state court. 
88

Jehovah's Witnesses were convicted and fined by the Hartford County Court of Maryland for conducting a meeting in a public park without a permit. Under a unique system of law in Maryland, the jury is the judge of the law as well as the facts. This means that normally there is no review of any question dependent on the sufficiency of evidence. Recognizing this Maryland rule, the Court of Appeals declined review, mainly on the basis that the issues were not "matters of public interest." 19 The Supreme court accepted jurisdiction noting that "in cases in which there is a claim of denial of rights under the Federal Constitution, this Court is not bound by conclusions of lower courts." 20

Unlike other cases requiring permits to carry on activities in public places, here there was no ordinance or statute requiring a permit. It was only through long standing "practice" that permits were obtained from the Park Commissioner by members seeking to utilize public places. In conformity with this practice, Niemotko et. al. requested the Commissioner for use of the park for four consecutive sundays. This permission was refused. Having been informed that the first sunday was scheduled for an Elk's Flag Day ceremony, the applicants

\footnotetext{
19 Niemotko v. Maryland, p. 270. 20 Ibid., p. 271.
} 
89

requested the use of the park for the next three sundays. This request was again denied.

The appellants then proceeded to hold their meeting on the second Sunday and were promptly arrested for disorderly conduct. The majority opinion of the Supreme Court, accompanied by the usual castigation of Mr. Justice Frankfurter in a concurring opinion, rebuked the "amorphous practice" of the municipality" whereby all authority to grant permits for the use of the park was in the Park Commissioner and the City Council."2l The Court pointed out that there were: "no standards" appearing anywhere; "no narrowly drawn limitations," "no circumscribing of absolute power;" and "no substantial interest of the community to be served."22 This was "Iimitless discretion" which on the face was unconstitutional.

The petitioners in their activity, the court noted, were not causing any disturbance, and from all indications were carrying on in orderly fashion. The contention that the park was a sanctuary for peace and quiet was rejected on the ground that the Elk's Flag Day ceremony which was permitted was hardly a peaceful endeavor.

The core of the whole matter however, lay in the basis of the petitioners" claim that equal protection as guaranteed by the Fourteenth Amendment was denied. The Court took note

$$
\begin{aligned}
& { }^{2 I} \text { Ibid., pp. } 271-272 . \\
& 22 \text { IbId., p. } 272 .
\end{aligned}
$$


90

of this and properly concluded that "the use of the park was denied because of the city Council's dislike for or disagreement with the Witnesses or their views." 23 Between this case and most of the other cases affecting the rights claimed by Jehovah's witnesses there is another striking dissimilarity; "This was an unusually clear case of 'unwarranted' discrimination in a refusal to issue a license, and a denial of equal protection." 24

The lengthy concurring opinion by Mr. Justice Frankfurter included his views on other cases whose opinions were delivered the same day.25 In his attempt to define a constitutional balance between basic freedoms such as speech and press vis a vis the interests of public order, Frankfurter cited a whole list of cases most of them dealing with the practices of Jehovah's Witnesses. 26 The gist of his opinion

23 Ibid.

${ }^{24}$ Pritchett, The American Constitution, p. 297.

25 Kunz v. New York, op. cit., and Feiner v. New York, 340 U.S. 315 (1951). Although the constitutional questions involved in these cases are quite similar to the Nietotko case, the parties were not members of Jehovah's Witnesses.

26 These cases were: Lovell v. Griffin, Jamison v. Texas, Largent v. Texas, Schneider v. Irvington, Martin v. Struthers, Prince v. Massachusetts and Cox v. New Hampshire, supra; Cantwellv. Connecticut, Marsh v. Alabama, Tucker v. Texas, Jones v. Opelika, Murdock v. Pennsylvania, Follett v. Mccormick, Saia v. New York and Chaplinsky v. New Hampshire, Infra. These and others, Frankfurter calls multifarious cases" which give expression to certain constitutional principles to be applied in determining the extent of freedom. 


\section{1}

was twofold: (1) to preserve law through freedom of expression, and (2) to grant to the legislative bodies the power to exercise this discretion without hampering them with undue constitutional construction.

The Niemotko case offers very little in terms of challenging constitutional implications. It was, in short, a rather "easy" case since the practices involved were extreme in their deviation from constitutional norms. Rank discrimination and arbitrary powers have never been questionable issues. The case however presents a relatively insignificant but interesting procedural ruling, viz., "the lack of standards in the license-issuing 'practice' renders that 'practice' a prior restraint in contravention to the Fourteenth Amendment."27 The main point here is that the customary "practice" of a municipality is accorded the same treatment and force as would be expected of a statute or an ordinance. In other words, although the Court recognized that the requirement for a permit was according to "practice" and not by statute, it did not differentiate the legal effect of both or either.

Exactly two years after the Court rendered the Niemotko judgment, a similar case 28 affecting members of the Jehovah's Witnesses was brought before the High court. This time the Witnesses were convicted for violating the ordinance of the

$$
\begin{aligned}
& 27 \text { Niemotko v. Maryland, p. } 273 . \\
& 28 \text { Fowler v. Rhode Island, } 345 \text { U.S. } 67 \text { (1953). }
\end{aligned}
$$


92

City of Pawtucket, Rhode Island, which prohibited all political and religious meetings in a public park. The ordinance did not prohibit visits or use of the parks by these groups, it only made unlawful meetings of a political or religious nature. On a particular day prearranged and designated by the Pawtucket congregation of Jehovah's Witnesses, a meeting was held in Slater Park of Pawtucket, in which some four hundred people attended, about one hundred fifty of them being Jehovah's Witnesses. A special speaker was brought in by the local Witnesses from Arlington, Massachusetts, who himself was a member of the same faith. Two loud speakers were used for the public address, but the meeting was generally orderly and no disturbances or breaches of the peace were caused. The speaker's address was entitled, "The Pathway of Peace," which, on the surface was innocuous enough, but he "launched forth" into the meaning of the Scriptures. He was immediately arrested by the police, and charged with violation of the ordinance. After his conviction he was fined $\$ 5.00$. The conviction was affirmed by the Rhode Island Supreme Court and finally the case reached the United States Supreme Court on appeal. The appellants contention was that the ordinance violated the First and Fourteenth Amendments.

Mr. Justice Douglas, whose opinion for the Court represented unanimous approval, disposed of the case in rather short order. The whole opinion covered only three pages. He noted 
93

first of all, the similarity of this case to Davis V. Massachusetts, $^{29}$ in which the court upheld the right of a municipality to control public meetings in a public place. Therefore, "we are invited by appellant to overrule it; we are asked by respondent to affirm it."30

Considering the case to be quite unlike Davis v. Massachusetts in a very important aspect, the Court declared the conviction invalid. While the ordinance itself was not offensive, Douglas pointed out that "Catholics could hold mass in Slater Park and Protestants could conduct their church services there without violating the ordinance."31 This showed plainly that "a religious service of Jehovah's Witnesses is treated differently than a religious service of other sects."32 This amounted to state peeference of certain religions over others, which of course was a violation of the First Amendment made applicable to states through the Fourteenth. Mr. Justice Frankfurter concurred with the majority opinion but not on the same ground. He felt that the action of the state violated the equal protection clause of the Fourteenth Amendment, and did not deny First Amendment guarantees. Mr. Justice Jackson concurred with this view. "The Methodist, Presbyterian, or

${ }^{29} 167$ U.S. 43 (1897).

30 Fowler v. Rhode Island, p. 69.

${ }^{31}$ Ibid.

${ }^{32}$ Ibid. 
Episcopal ministers, Catholic priests, Moslem Mullahs, and Buddhist monks could all preach to their congregations in Pawtucket's park with impunity, "33 why not the Jehovah's Witnesses? Perhaps because,

No instrumentality of the state government is likely to abuse the freedom of well-established churches, such as the Episcopalian, Catholic, Presbyterian, Jewish, or Baptist;. . . Lan unpopular7 sect is much more likely to run afoul of the law. 34

In holding that the ordinance violated the First Amendment the Court felt that "to call the words which one minister speaks to his congregation a sermon, immune to regulation, and the words of another minister an address, subject to regulation, is merely an indirect way of preferring one religion over another."35 What the court seems to say in this case is, a municipal ordinance which is so construed as to penalize certain religious groups for carrying on peaceful meetings in a public park, while other religious groups are permitted to conduct their services with impunity, violates the First and Fourteenth Amendments of the Federal Constitution.

Some nine months following Fowler v. Rhode Island, in

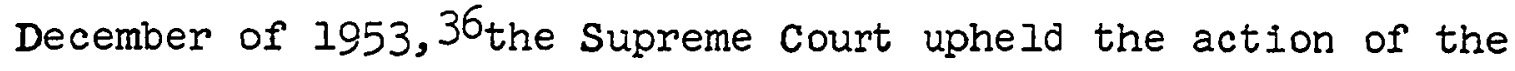

33 Ibid., p. 70.

34 Green, Washington University Law Quarterly, XXVII p. 524. 35Fowler v. Rhode Is land, p. 70 . $36_{\text {Poulos v. New Hampshire, }} 345$ U.S. 395 (1953). 
high court of New Hampshire in sustaining the conviction of members of Jehovah's Witnesses who conducted services in Goodwin Park, of Portsmouth, New Hampshire, after their aplication for a permit had been denied. Certain procedural implications marked the case with some constitutional difficulty. Against the vigorous dissents of Justices Black and Douglas, Mr. Justice Reed delivered the opinion of the Court. Upholding the validity of the statute, two issues were quickly settled by Mr. Justice Reed. (1) The licensing authority was properly limited by the statute, to exercise uniformity of method of treatment; to refrain from unfair discrimination; and the licensing authority had no discretion or the power to delegate its authority. (2) The Court was not settling the problem as to whether a city may prohibit religious meetings in all of its parks, rather to decide that a city may designate one of its parks for the purpose of public meetings provided the system was fairly employed without bias or discrimination.

Both the state courts and the supreme court agreed that the refusal of the license by the city Council was "arbitrary and unreasonable," 37 but refused to dismiss the prosecution on the grourid that;

The respondents could have raised the question of their right to licenses to speak in Goodwin Park by proper civil proceedings in this court, but

37 Ibid., p. 400. 
they chose to deliberately violate the ordinance. 38

Referring to the decision of Cox v. New Hampshire 39 the State Supreme court held that as the ordinance was valid on its face, the remedy was by certiorari to review the unlawful refusal of the Council.to grant a license, not by proceeding to hold a public meeting, then defending because the refusal of the license was arbitrary. To the majority of the Court this seems to have been the most important constitutional question. Indeed, Mr. Justice Frankfurter in a lengthy concurring opinion felt this to be the only issue before the courts.

The validity of this procedural requirement of New Hampshire -- that the remedy for an unlawful denial of a license is mandamus or certiorari -is the only isslie which the New Hampshire Supreme court had before it. 40

Mr. Justice Reed, in the main body of his opinion dealt with two constitutional issues. First, the constitutionality of the requirement of a license to conduct religious services in Goodwin Park. Second, the validity of the unlicensed action of one who has been arbitrarily and wrongfully refused a permit. It was precisely on this point that Frankfurter balked. "That

${ }^{38}$ Ibid., the quotation was taken from the decision of the Supreme Court of Massachusetts, State v. Poulos, 97 N.H. 352. 88A. 2d 860 .

39Discussed above.

40 Fowler v. Rhode Island, p. 418. See concurring opinion by Mr. Justice Frankfurter. 
is not the second contention. It is the only contention," 41 sald the learned Justice. "A wrongful refusal to license is not a bar to a prosecution for acting without a license." 42 In convicting the appellants, the state courts were not enforcing the licensing ordinance, they were enforcing the general procedural law of New Hampshire.

The contention of the appellants was based partly on two previous cases 43 in which the court struck down the conviction of individuals who had held public meetings after licenses to conduct them were denied. These two cases were differentiated by the court in that in both cases, the ordinances themselves were declared unconstitutional. In the instant case, the ordinance was held valid, therefore, the decisions rendered in the Cantwell and Thomas cases were not controlling. Neither were Kunz v. New York, Hague v. C.I.O., and Saia $v$. New York ${ }^{44}$ controlling because in these cases the ordinances were held invalid, "not becuase they regulated the use of the parks for meeting and instruction but because they left complete discretion to refuse the use in the hands of officials." 45

\footnotetext{
41 Ibid., p. 419.

42 Ibid., p. 420. Connecticut.

43 Thomas v. Collins, 323 U.S. 516 (1945), Cantwell v. 44 The saia case is discussed in Chapter V. 45 poulos v. New Hampshire, pp. 406-407.
} 
98

Justices Black and Douglas in their dissent were not so concerned with procedural protection as they were with the censorship of a "preferred" guarantee. They agreed with Mr. Justice Reed in that the state may prosecute a person who, without procuring a permit, ran certain business, such as erecting structures, purchasing firearms, storing explosives, and the like, but this "case is quite different from a legislative program in the field of business." 46 "The First Amendment affords freedom of speech a special protection." 47 Referring to Near v. Minnesota, 48 Douglas declared that "no matter what the legislature may say, a man has the right to make his speech, print his handbill, compose his newspaper, and deliver his sermon without asking anyone's permission."49 Employing clear and forceful language Douglas continued:

If the citizen can flout the legislature when it undertakes to tamper with his First Amendment rights, I fail to see why he may not flout the official or agency who administers a licensing law designed to regulate the exercise of the right of free speech. Defiance of a statute is hardly harmful to an orderly society than defiance of an administrative order. 50

46 Ibid., p. 423. See dissenting opinion by Douglas, J. 47 Ib1d., 422. See dissenting opinion by Justice Black. This argument actually smacks of a preferred position of a "preferred position."

48283 U.S. 697 (1931).

Poulos v. New Hampshire, p. 423.

50 Ibid., pp. 423-424。 
The requirement that the licensing authority stay within the bounds of reason, and be free from unfair discrimination was also attacked by the dissenters; for "even a reasonable regulation of the right to free speech is not compatible with the First Amendment." 51 This doctrine of regulating free speech, both dissenters called a "creeping censorship" already loose in the land. Any statute which requires a license for the right to make a speech "adds a burden to the right." 52 The issuance of a license for the exercise of free speech is a discreticnary action which the Constitution prohibits according to the dissenting view.

It is well known to students of American Constitutional Law that the precise bounds of the law are never attainable. Especially is this true in cases where the Court itself is not in general agreement. This problem is further intensified when the ruling is reached through varying approaches. The instant case $1:$ an example of this unusual but not uncommon frustration. The majority opinion was premised on two main constitutional criteria; that of. (I) infringement of free speech, and the (2) administration of a proper procedural

5lIbid., p. 425. This marks a distinction between the present case and Cox $v$. New Hampshire, supra. There the sole charge was that appellants were taking part in a parade or procession without a license. Under police powers, the state's control over public streets was permissible. They were not prosecuted for distributing leaflets, displaying placards, or addressing the public. It was not the right of free speech which was curtailed.

$$
52 \text { Ibid., p. } 424 .
$$


100

defense. On both counts, the Court upheld the action of the state. Mr. Justice Frankfurter denied the existence of the first issue and concurred with the majority on the basis of the second contention. Justices Black and Douglas, ignored the second contention and dissented against the majority on the basis that the first contention -- the right of free speech -- was inviolate, and therefore, the question of procedural protocol was superfluous. Perhaps for this and other reasons the appeal for a rehearing 53 was denied by the court. The Poulos case established two important constitutional principles. (1) an ordinance which leaves to the licensing authority no discretion as to the granting of licenses, no power to discriminate and no control over speech, and as calling merely for the adjustment of public religious practices with the reasonable comfort and convenience of the city, does not violate the provisions of the First or the Fourteenth Amendments. (2) The proper remedy for a wrongful denial of a valid license is by certiorari to review the unlawful action of licensing officials, "not that of holding unlicensed services and then defending because the refusal of the license was arbitrary. "54 In all these cases there is one discernible theme:

53345 U.S. 978 (1953)。

${ }^{54}$ Paul A. Freund, et. al., Constitutional Law: Cases and other Problems, II (2 vols., Boston: Little, Brown, and (c., 1961$), \mathrm{p}_{0} 1448$. 
101

The problem is posed in terms of the traditional technique of balancing the individual linterest in religious freedom against society's interest in promoting what the legislature believes to be the common good. 55

In the use of public parks and streets for the purpose of propagating religious views, great weight of validity is accorded legislative enactments. The statutes and ordinances being reasonable and non discriminatory, nothing short of a direct curtailment of "preferred" Iiberties will provoke the court to strike down state regulatory measures. If there is any hesitation on the part of the Court to invalidate state action infringing individual liberties, this is not true of cases in which the state permits its agents to exercise "unlimited discretion" or "undue discrimination" in regulating the use of public places. In these instances, the Court will act with dispatch in declaring state action void. 


\section{CHAPTER V \\ "SOUND DEVICES" AND "FIGHTING WORDS"}

Some of the cases examined in previous chapters uphold the notion that "a fundamental element in freedom of religion, as in freedom of speech, is that religious activity shall not be subjected to previous restraint."l Cantwell v. Connecticut, ${ }^{2}$ a case celebrated for its emphasis on unrestricted freedom, further emphasized the above quoted rule. But the most notabie aspect of the case is that it was the first case in which religious freedom per se was read into the Fourteenth Amendment making its infringement by states unconstitutional. Newton Cantwell and his two sons, Jesse and Russell, members of the Jehovah's Witnesses faith, were arrested in New Haven, Connecticut, and charged with five counts of statutory and common law offenses. Only the third and fifth counts have relevance here for the state courts acquitted the petitioners of the other three counts.

The third count affirmed by the Connecticut supreme Court charged all of the Cantwells with the violation of a state statute which made it unlawful for any person to solicit "money, services or subscriptions" for religious purposes without the approval of the secretary of the Public Welfare

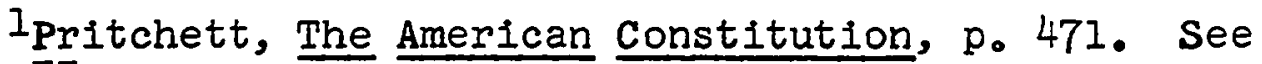
Chapter II.$$
\text { 2310 U.S. } 296 \text { (1940). }
$$ 
103

Counc1l. The statute authorized the secretary to determine the nature of the cause as to whether it was religlous, and also authorized him to revoke the license at any time. The petitioners claimed that their activities were not within the meaning of the statute, but consisted only of distribution of books and pamphlets, and therefore, the conviction denied them freedom of speech, and prohibited their free exercise of religion.

The facts adduced to sustain the convictions were as follows: On the day of their arrest, the appellants made houseto-house calls on Cassius street, a thickly populated neighborhood of New Haven, in which about ninety per cent of the residents were Roman Catholics. Each appellant was equipped with a bag full of literature and a portable phonograph. Anyone who responded to the call of the appellant was introduced to one of the books carried by the solicitor. Further, the appellant asked his hearer for permission to play a record describing a book called "Enemies." The record, which in part attacked organized religion and the Roman Catholics, was not played uniess the person who was called gave his permission. Contributions were accepted only to the extent that the listener was willing to make it. If a constribution was made, a pamphlet was delivered upon the condition that it would be read.

The appellants' contention that they were denied freedom of speech and religion was guaranteed by the First Amendment which made states incompetent to abridge these freedoms via 
104

the Fourteenth Amendment, was struck down by the high court of Connecticut. It was solicitation which brought the appellants within the sweep of the Act, said the court. The state court insisted that

The purpose of the statute is to protect the public from fraud in the solicitation of money or other valuables under the guise of religion. The only activity of any alleged religious group which it is sought to regulate is such solicitation. 3

With this reasoning the United States Supreme Court refused to go along. Mr. Justice Roberts representing a unanimous verdict said,

We hold that the statute, as construed and applied to the appellants, deprives them of their liberty without due process of law in contravention of the Fourteenth Amendment. 4

On the surface, it appears that the Court took a very libertarian view concerning the rights of free speech and religion. It even went so far as to declare that of the two concepts embraced by the First Amendment, freedom to believe, and freedom to act, the former was absolute. Thus only conduct was subject to regulation by the state for the protection of society. Such a view, though not novel, evoked certain reactions. "Protection of society" means:

The Court must decide the question by weighing

$$
\begin{aligned}
& 3_{\text {Ibid., p. } 298 .} \\
& { }^{{ }_{\text {Ibid., }} \text { p. } 303 .}
\end{aligned}
$$


105

the relative values of the social interest in personal liberty as opposed to the social interests of society as a whole. Therefore, since this ordinance is not an attempt to regulate petitioners for the protection of society, the court seems justified in holding that it is not a proper exercise of the police power. 5

There were others who felt that the Court had modified its traditional position concerning the power of states to regulate social activities in the public interest.

Until recently, the Supreme Court has indicated that freedom of expression, for whatever purpose, was subject to restraint whenever state or municipal legislative bodies reasonably deemed restraint necessary to safeguard peace, good order or morals of the community. Today, however, the court has manifested a decided change in its views and the permissible degree of restraint upon free expression to achieve ends within the proper sphere of police power is greatly limited.6

There seems to be an ambivalence here, for if the decision of the court in the present case provided a fear that the court had become too extreme in its broad interpretation of the First Amendment Clauses; or that it was rendering a completely consistent decision; that fear or joy, as the case may be, is premature and unjustified in view of the following argument presented by the Court. "The Act requires an application to the Secretary of the Fublic Welfare Council;. . that he is

5Indiana Law Journal, XVIII, p. 315.

$\sigma_{\text {A.J. Blackman, "Freedom of Expression -- Administra- }}$ tive Licensing -- Breaches of Peace" Southern California Law Review XIV (Nov., 1940), p. 77 . 
106

empowered to determine whether the cause is a religious one, and that the issue of a certificate depends upon his affirmative action."7 It was this discretionary power in a public official over matters of religious activity that the court felt was an unconstitutional infringement. Needless to say, the Court has never looked with the slightest degree of favor on discretionary action of officials over the granting of licenses in activities concerning religion, speech, press or assembly .

The Court was careful to note that the state may protect its citizens from fraudulent solicitation, and the exercise of religion too may be subjected to slight inconverlences at times.

The State is I1kewise free to regulate the time and manner of solicitation generally, in the interest of public safety, peace, comfort or conven-. ience. But to condition the solicitation of aid. for the perpetuation of religious views or systems upon a license, the grant of which rests in the exercise of a determination by state authority as to what is a reilgious cause, is to lay a forbidden burden upon the exercise of liberty protected by the Constitution.8

It was thus recognized "that the exercise of religion might be subjected to reasonable regulation so far as such exercise involved freedom to act."9

${ }^{7}$ cantwell v. Connecticut, p. 305.

I Ibid., pp. 306-307.

Waite, Minnesota Law Review, XXVIII, p. 227. 
The State also asserted that the action was valid because if the licensing officer acted arbitrarily or capriclously, his action was subjected to judiclal correction. To this assertion the Supreme court declared that "the availabilIty of a judicial remedy for abuses in the system of licensing still leaves that system one of previous restraint which, in the fleld of free speech and press, we have held Inadmissible. "10 Thus the court:

rejected the state!s contention that judicial remedy for possible abuses of the licensing officer in arbitrarily withholding permits is sufficient to protect constitutional rights. Such system. . . is still one of previous restraint. II

The third count upon which all of the appellants were convicted was thus invalidated by the supreme court. The fifth count, which was a charge of breach of the peace was held against only one of the appellants, Jesse Cantwell. This too, the high court struck down.

The conviction of Jesse Cantwell by the state courts came about as a result of the following conditions: The appellant on April 26, 1938, was in a public street trying to impart his views to all who would listen. He requested two pedestrians permission tn play the phonograph to them. The request was granted. The record, "Enemies," was an attack

${ }^{10}$ Cantwell v. Connecticut, p. 306.

11 Blackman, Southern California Law Review, XIV p. 77. 
against all organized religions. It singled out the Roman Catholic Church as a part of this evil. The listeners were members of the Catholic faith and were offended by the statements made by the record. One of them sald that he felt like hitting Cantwell, and the other said he was tempted to throw Cantwell off the street, whereupon, the appellant immediately gathered his equipment and left.

After weighing the facts, the Supreme Court recognized the purposes and objectives of general breaches-of-peace laws, and also made reference to the necessity of controlling acts which would tend to menace the order and tranquility of society. In this responsibility there was, obviously, a dilemma which was not easily reconcilable.

When clear and present danger of riot, disorder, interference with traffic upon the public streets, or other immediate threat to public safety, peace, or order, appears, the power of the state to prevent or punish is obvious. Equally obvious is it that a state may not unduly suppress free communication of views, religious or other, under the guise of conserving desirable conditions.12

It was the opinion of the court that Cantwell's conduct did not constitute a breach of the peace. There was no provocative or abusive language, no assault or threatening of bodily harm, no intentional discourtesy, "on the contrary, we find only an effort to persuade a willing listener to buy a 
109
book."13 When the listeners became offended and expressed their feelings, the solicitor immediately left in orderly fashion. Because sharp differences rise in the realms of religion and politics, the court recognized that exaggeration, and false statements about the beliefs of others are expected.

But the people of this nation have ordained in the light of history, that, in spite of the probability of excesses and abuses, these liberties are, in the long view, essential to enlightened opinion and right conduct on the part of the citizens of a democracy. 14

In the last analysis, it was the court's opinion that in the absence of a narrowly drawn statute specifying certain conduct which would constitute a clear and present danger, the appellant's action, considered under constitutional guarantees, did not present a clear menace to the public peace and order which would make him liable to conviction of a common law offense. Or in other words:

The statute was held invalid since it did not provide adequate standards to assure against its being enforced arbitrarily and the breach of peace convictions were set aside since, in the opinion of the court, the disturbance created by the Witnesses did not constitute a clear and present danger. 15

\footnotetext{
13 Ibid., p. 310.

$14^{\text {Ibid. }}$

15Peter Bachrach, Problems in Freedom (Penn: Telegraph
} Press, 1954), p. 134 . 
110

The rationale of the court in this case -- as in most free speech decisions -- "rested on the importance of unhampered discussion to the functioning of our polity; the absence of this political concern in the Cantwell case may explain the narrowing of the constitutional base to freedom of religion alone." 16 The state "may regulate it [free speech7 in the course of exercising its police power, but public power ends where an infringement of the fundamental right begins." I7

The constitutional importance of the Cantwell case embraces three general areas. First, the constitutional guarantee of freedom of conscience and of religious belief is absolute; although freedom to act in accordance with these beliefs may be subject to regulation for the protection of society, such regulation must not, in attaining a permissible end, infringe the protected freedom. It was under this reasoning that the Court invalidated the conviction of Jesse Cantwell who was charged with breach of the peace. Secondly, the fact that the arbitrary and capricious action of a licensing official is subject to judicial review is insufficient to validate a statute. Thirdly, and this is the most important aspect in terms of the development of general constitutional law; "The Cantwell case provokes the first supreme Court decision

16"Fourteenth Amendment -- Religious Liberty," Columbia Law Review XI (June, 1940), p. 1.069 .

17 "Freedom of speech and of Religion -- Fourteenth Amendment," St. John's Law Review XV (Nov., 1940), p. 95. 
III

squarely holding that freedom of religion is protected against state interference by the Fourteenth Amendment." 18

The Cantwell decision seems to indicate that the decision and the final outcome of the case is determined by "the quality of the public interest concerned rather than a judgment as to the qualitative degree of threat to some vital concern of the state." 19

The doggedness of the Jehovah's Witnesses to present their message through certain sound devices is revealed in the remark of Willard Sperry, and is illustrative of their activities which have necessitated continued court action.

A Quaker friend tells me that, when Quakers in the camps for Conscientious objectors gather for silent meetings, a Jehovah's Witness stations himself outside an open window and turns on his omnipresent Victrola.20

When reference is made to Jehovah's Witnesses and "sound" devices," the case which appropriately presents itself is Saia

18"Fourteenth Amendment -- Religious Liberty," Columbia Law Review, XI (June, 1940), p. 1068. The writer declares the stage had been set by "favorable dicta," which he claims to be the following cases: Hamilton v. Regents, Meyer v. Nebraska, Gitlow v. New York, schnelder v. Irvington, Near v. Minnesota, Grosjean $v$ American Press. Supra. The same conclusion is drain In "ReIlglous freedom - Constitutionality of state Statutes Prohibiting Solicitation for Religious Causes Without the Approval of an Administrative official," Iowa Law Review, XXVI (Nov., 1940), p. 129.

$$
\begin{aligned}
& { }^{19} \text { Ibid., p. } 1071 . \\
& { }^{20} \text { Sperry, Religion in America, p. } 101 .
\end{aligned}
$$


v. New York. 21 This was THE sound device case. The appellant in the instant case, a Jehovah's Witness, was convicted of violation of a Lockport, New York, ordinance which prohibited the use of sound amplification devices in public parks without permission from the Chief of Police. For the first four sundays of his lectures on religious subjects, the appeliant was granted proper permission. Upon application for another permit, he was denied a permit by the Chief of Police on the basis of testimony received from some citizens who claimed that the noise was disturbing. The appellant proceeded, without a permit, to continue the use of his loudspeaker. He was promptly arrested and convicted by a County Court for violation of the statute. The New York Court of Appeals sustained the judgment and the case was brought to the supreme Court on appeal.

In what turned out to be a bitter division on the court, Mr. Justice Douglas calmly delivered the majority opinion which leaned heavily on stare decisis. The opinion was short and clear relying on Lovell v. Griffin, 22 as its main precedent. As in the Lovell decision, the court held that the ordinance estabIished previous restraint therefore it was unconstitutional on its face. The ordinance had the "same effects" of not only that Involved in the Lovell decision, but of Cantwell v. Connectlcut and Hague v. C.I.O. 23 as well. "A more effective

$$
\begin{aligned}
& 21_{334} \text { U.S. } 558 \text { (1948). } \\
& 22303 \text { U.S. } 444 \text { (1938). } \\
& 23_{307} \text { U.S. } 496 \text { (1939). }
\end{aligned}
$$


previous restraint," said Douglas, "is difficult to Imagine."24

\begin{abstract}
Unless we retreat from the firm positions we have taken in the past, we must give freedom of speech in this case the same preferred treatment that we gave freedom of religion in the Cantwell case, freedom of the press in the Griffin case, apd freedom of speech and assembly in the Hague case. 25
\end{abstract}

What appeared offensive to the majority were two elements implicit in the ordinance. (1) The sweeping nature of the statute. The court felt that the abuses created by loudspeakers should be controlled by narrowly drawn statutes, not one denying the right to their use. (2) The discretion given to a public official over matters relating to free speech. "When a city allows an official to ban them [loud-speakers] in his uncontrolled discretion, it sanctions a device for suppression of free communication of ideas."26 The courts, in the opinion of the majority, must balance the various community interests concerning the constitutionality of local laws.

Four Justices, Frankfurter, Jackson, Reed and Burton dissented. Both Frankfurter and Jackson wrote their dissenting opinions the vigor of the former being overshadowed by the vehement language of the latter. To Mr. Justice Frankfurter, the appellants abused their right of free speech in interfering with the peace and comfort of others by the use of a sound

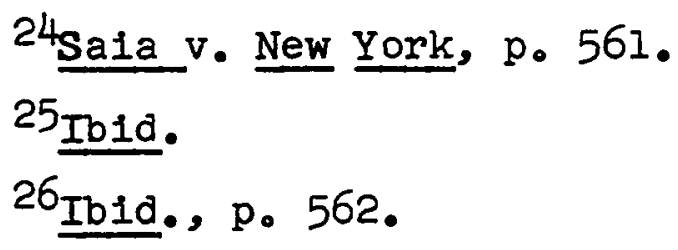


114

amplifying mechanism. He noted the relatively small size of the park, and unlike human speech, those who refused to listen could not move out of earshot of a loud-speaker. Furthermore, When the enfoyment of the park by those for whom it was intended was obstructed, it was not unreasonable for the Chief of Police to refuse to grant permission. Thus there was here no showing of either arbitrary action or discrimination. The main basis for Mr. Justice Frankfurter's dissent seems to be the use of an instrument to amplify speech which somehow changed the meaning of the freedom of speech. On this score, the majority felt that noise could be controlled by regulating decibels, and that would be the remedy.

To Mr. Justice Jackson, the prohibition of a municipality from policing or controlling the use of sound equipment in a public park was "astonishing news."27 Moreover:

I think it is a starting perversion of the constitution to say that it wrests away from the states and their subdivisions all control of the public property so that they cannot regulate or prohibit the irresponsible introductiog of contrivances of this sort into public places. 28

The Justice even condemned the Court for thinking that there was here a fundamental issue. Sald Jackson, $\mathbf{n}_{\text {To }}$ my mind this is not a free speech issue." 29 He continued to rail the majority

27Ib1d., p. 567. See Justice Jackson's dissenting opinion. 28 Ib1d.

29Ib1d., p. 568 . 
115

for being inconsistent with the decision of McCollum v. Board of Education. 30 rendered a few weeks earlier in which the Court prohibited the use of tax-supported property by religlous groups. In the instant case, the court was permitting what it prohibited in the McCollum case. And finally, Jackson became almost irrational when he crled, "I disagree entirely with the idea that 'Courts must balance the various community interests. .' It is for local communities to balance their own interests."3I on this issue, Frankfurter's view appears to be more appropriate -- certainly more reasonable. The limitations imposed by New York, upon the appellants did not exceed the balance of conflicting interests, therefore, the court was not removed from considering the issue of conflict of community interests; in this case however, the Court erred in thinking that the municipality had exceeded its bounds in interfering with individual rights. 32 The court had jurisdiction, but it erred in judgment.

30333 U.S. 203 (1948).

\section{1} Sa1a v. New York, p. 571.

32 In Kovacs v. Cooper, 336 U.s. 77 (1949), the court by a five to four majority modffied its position taken in the Saia case. The ordinance prohibiting "loud and raucuous" noises by sound trucks was upheld. Said Justice Reed, speaking for a siim majority, "unrestrained use throughout a municipality of all sound amplifying devices would be intolerable." Jackson concurred with the majority, not on the basis of Justice Reed's reasoning, but on the rationale of his argument in Saia, viz., the ordinance unconditionally banned all sound trucks. 
116

The two main criteria underlying the majority opinion in this case were "previous restraint," on free speech, and lack of "standards" for the exercise of a public official's discretion.

The contribution of Jehovah's Witnesses to the development of Constitutional Law is a well established fact. But if such were not the case, the contribution would be in the unique and novel conditions which seem to surround the activity of these ministers of the Word. The case of Chaplinsky v. New Hampshire 33 presents a unique situation, indeed it is in part amusing if not offensive.

The case is unique not because the court might have used the danger test and found that no grave evil existed and that Chaplinsky's words could not therefore be punished; it is unique because Justice Murphy almost makes the test of legitimacy the contribution of the challenged speech to the truth. 34

This "name calling," or better known as "fighting words" case took place in Rochester, New Hampshire. The appellant, Chaplinsky, a member of the Jehovah's Witnesses, one busy Saturday afternoon was engaged in the distribution of literature on a busy street in Rochester. Some members of the local citizenr, filed a complaint with the City Marshal, who told

33316 U.s. 568 (1942).

34 Walter Berns, Freedom, Virtue, and the First Amendment (Baton Rouge: Louisiana state University Press, 1957), p. I03. 


\section{7}

those bringing the charges, Chaplinsky was lawfully engaged; and at the same time the Marshal warned Chaplinsky that some of the people had filed complaints. Sometime later a riot occurred and Chaplinsky was arrested by a police cificer. He was not aware that he was being arrested until they encountered the Marshal who was on his way to quell the disturbance. Upon discovering that he was being arrested and being warned again by the Marshal for his activities, Chaplinsky allegedly said to the Marshal, "You are a God damned racketeer" and "a damned Fascist and the whole government of Rochester are Fascists or agents of Fascists." 35 Later in Court, the appellant admitted to the use of these words with the exception of the name of the Deity. The lower court of New Hampshire convicted ChapIinsky of violation of a statute prohibiting the use of "offensive" "derisive" or "annoylng" words in a public place. This conviction of a breach of the public peace was affirmed by the New Hampshire Supreme Court. On appeal to the United States Supreme Court the appellant contended that the statute denied him the freedom of speech, religion, and press, therefore violating the Constitution. The Supreme Court held that only an attack on the right of free speech was warranted inasmuch as "cursing a police officer is [hardly an/ exercise of religion in any sense of the term." 36

35 Chaplinsky v. New Hampshire, p. 569.

${ }^{36}$ Ibid. , p. 571. 
118

In delivering a unanimous verdict, Mr. Justice Murphy began by observing that the Fourteenth Amendment did not afford an absolute guarantee of free speech at all times under all circumstances. Furthermore, "there are certain well-defined and narrowly limited classes of speech, the prevention and punishment of which have never been thought to raise any constitutional problem."37 "Obscene," or "lewd" language, and "insulting," or "fighting words -- those which by their very utterance inflict injury or tend to incite an immediate breach of the peace," 38 were punishable acts.

It has been well observed that such utterances are no essential part of any exposition of ideas, and are of such slight social value as a step to truth that any benefit that may be derived from them is clearly outweighed by the soclal interest in order and morality. 39

It is over this philosophy that Mr. Berns has declared this to be a unique case. He feels that the reasoning implies that if the statement is true, speech, no matter how offensive, may be held valid.

While it can be easily agreed that denouncing a policeman as a "damned Fascist" is not an exposition of an idea having constitutional merit, there is other speech, equally derisive, that may lay claim to being legitimate exposition. Whether it

\footnotetext{
37 Ib1d., pp. 571-572.

${ }^{38}$ Ibid., p. 572 .

39 Ibid.
} 
constitutes a 'step to truth! depends on how truth is defined. If truth is the idea that wins in the market place, calling a policeman a Fascist may be a vital step to truth. Besides, the policeman might well be a Fascist. 40

Among other things (discussed above), the Chaplinsky case made a contribution in setting up a criterion for the determination of what constitutes provocative language. The test, according to the court, was, if the language would provoke the "average person" to retaliation, the prohibition of such words would not violate the Fourteenth Amendment and the guarantees contained therein. Thus a prohibitive ordinance applied against a person for addressing another as a "damned racketeer," or a "damned Fascist," does not substantially or unreasonably infringe upon freedom of speech.

Although it established no important constitutional principle, the high court rightfully upheld the right of the state courts to refuse to admit evidence by the defendant proving the truth of utterances.

Comparing the Cantwell and the Chaplinsky cases, the conclusion is obvious. The clear and present danger test is applicable in a legitimate attempt at communication, such as in the Cantwell case, no matter how disagreeable and provocative the speech may be. In other words, provocation is not enough to curtail speech, there must be a "danger" which the

40 Berns, Freedom Virtue and The First Amendment, p. 108. 
state has a right to prevent. The Chaplinsky case on the other hand, involved the use of abusive epithets which are not subject to the clear and present danger test. "Fighting Words" have no substantial part in the communication of ideas, they are in themselves subject to control. The test over abusive language more than just the dangerous condition it may provoke, involves the offensiveness of the language itself to the "average person."41

The sharp division of the court over some of these issues indicates the extent of the problem therein. It is also a proper reflection of the attitude of the community.

\begin{abstract}
Those who are inclined to give freedom of speech a 'preferred position' over peace and order would undoubtedly argue that the very foundation of free expression is threatened when it is silenced because of the intolerance and bigotry of a mob toward unorthodox views. The police and deputies ought to have protected the constitutional rights of the Witnesses rather than the illiberalism of the hostile crowd. Those who hold to the contrary position argue that order is a prerequisite to freedom of speech. Therefore, if the police felt that a clear and present danger of a riot existed in this case, they were justified in preventing violence the best way they could regardless of who was at fault. 42
\end{abstract}

4I The case of Terminiello vo Chicago, 337 U.S. I (1949), brought before the Court seven years after Chaplinsky, added emphasis on the clear and present danger aspect of derisive language as the important issue in cases involving "fighting words.

42 Bachrach, Problems in Freedom, p. 133. 
121

The Court has certainly not been oblivious to the existence of these issues, neither has it been wandering aimlessly in an uncharted judicial sea. If anything, the cases examined in this chapter reveal the importance of controlling breaches of peace by the states under customary common law practices. But the power of the states relative to public disturbances is subject to narrow IImitations when the regulation is aimed at actions involving speech.

The state unquestionably possesses authority to regulate -- even to prohibit -- activity of any nature, if the action disturbs the peace and welfare of the community, or if the action presents an immediate danger to the good order of the public. But this authority itself is subject to restrictions when the action it seeks to curtail affects a fundamental freedom. When the preservation of a fundamental freedom comes in conflict with the preservation of peace and order -- as has been the issue of most or the cases examined above -- everything being equal, the court will give great weight to basic freedoms, or as is frequently necessary to do, the court will decide each case as it arises according to its own merits. 


\section{CHAPTER VI \\ LIFE, LIBERTY, AND LICENSE TAXES}

Historically, the American people have adhered to the belief that only as the individual is free can the American community itself prosper in material and spiritual well-being. The relative freedom accorded individuals has unquestionably enhanced the development of business enterprises. But the institutions of business, although free in their inception, have been restricted in recent years by the ever expanding necessity of regulation for the public welfare. There have been various ways by which business activities have been restricted. One of the best means for this restriction has been the requirement of a license tax. To be sure, business taxes are seldom employed to cripple an enterprise, neither are they necessarily revenue measures. But the licensing system has been one way of regulating -- and promoting -- economic endeavors for the good of the public in general.

More by accident than by design, it took the Jehovah's Witnesses to annoy the court and irritate the public with the inevitable conflict of cherished individual liberties against necessary laws to control and promote economic institution. The inevitability of the conflict was not the making of this sect, their transgression was in bringing it to light when they did. The vice lay in the fact that the dilemma was "invoked by persons we don't like passing out pamphlets we don't 
care to read."I

The cases to be examined in this chapter are those in which the Witnesses claimed their liberty was violated by the requirement of license fees to peddle their religious literature. Next to the flag salute cases, the cases herein examined evoked more public reaction than any other series of cases affecting the Jehovah's Witnesses. In reality, the first case to be examined here, Jones v. Opelika, ${ }^{2}$ provoked more reaction by authoritative writers and journals than did any one of the flag salute cases. At least two features are noteworthy in distinguishing the reaction to the license tax cases from the flag salute cases: (I) The writers themselves who contributed to publicity naturally tended to be adverse to license fees in matters affecting free press. (2) The ordinary man on the street knew little and cared less about the transcendent nature of basic liberties and their relation to the qualities of general license taxes. The issue certainly did not appear as clear and dramatic to the average man on the street as did the practice of saluting the flag; or non-salute as the case may be. In short, most Americans are not "procedural" lawyers, but they are flag saluters par excellence!

The case of Jones $\mathrm{V}$. Opelika was heard together and decided with the cases of Bowden et. al. v. Fort Smith, and

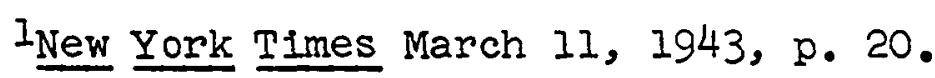

2316 U.S. 584 (1942). 
Jobin v. Arizona. 3 In each of these cases, members of Jehovah's Witnesses were involved over an ordinary license tax passed by the states to regulate commercial enterprises, and not to discriminate against any particular religious group. These ordinances were applicable to all peddlers, venders, and transient merchants.

The petitioner, from Alabama, was charged by the City of Opelika for a violation of its licensing ordinance for selling books without a license. The ordinance required all book agents (Bibles excepued) to pay a license fee of $\$ 10.00$ per annum; for transient dealers, $\$ 5.00$ per annum. The ordinance also authorized the City Commission to revoke licenses with or without notice. It was here that the petitioner demurred. "Alleging that the ordinance, because of unlimited disecretion in revocation and requirement of a license, was an unconstitutional encroachment upon freedom of the press." 4 The petitioner's claim that he was an ordained minister and therefore not subject to the ordinance was dismissed by the lower courts.

The Alabama Appeals Court sustained the petitioners contention that the ordinance conferred unlimited discretion, whereupon the Supreme Court of Alabama reversed the judgment of the Appeals Court. The United States Supreme Court granted certiorari but dismissed the writ for lack of final judgment.

\section{$3_{\text {Ib1d. }}$ \\ ${ }^{4}$ Ibid., p. 587.}


125

The case was then returned to the Appeals Court of Alabama which rendered final judgment sustaining the conviction. The Alabama Supreme Court affirmed the decision and the United States Supreme court granted a rehearing. Thus even before the final decision was rendered in the case, confusion over procedural technicalities as well as bewilderment over substantive measures had been experienced.

In the case arising from convictions of a Fort Smith, Arkansas, ordinance, the petitioners, Bowden and Sanders, were playing phonographic transcriptions of Bible lectures without paying a license fee prescribed by the ordinance. The schedule of fees in this case was $\$ 25.00$ per month, $\$ 10.00$ per week, or $\$ 2.50$ per day for all peddlers.

The petitioners in the exercise of their beliefs concerning their duty to preach the gospel, admitted going from house to house without a license - .distributing books setting forth their views to the residents in return for a contribution of twenty-five cents per book. When persons desiring books were unable to contribute, the books were in some instances given away free. 5

The Jobin case arose from a conviction in the city of Casa Grande, Arizona. The city ordinance made it a misdemeanor for any person to carry on a business occupation without first procuring a license. For transient merchants and vendors the

${ }^{5}$ Ib1d., p. 589 . 


\section{6}

fee was $\$ 25.00$ per quarter payable in advance. Jobin, a Jehovah's Witness, was convicted of violating the ordinance by carrying on the business of peddling without procuring a Ilcense. The appellant admittediy engaged in the activity of selling and distributing pamphlets and books. In most cases he was attempting to sell a book entitled, "Religion," for twenty-five cents. When the book was purchased, the purchaser was given other pamphlets free of charge, and in some cases the book and/or pamphlets were left with the prorietor even when there was no purchase.

\footnotetext{
When arrested, the appellant stated that he was

iselling religious books and preaching the gospel of the Kingdom,' and that because of his religious beliefs he would not take out a license. 6
}

The petitioner's motion that the ordinance denied him the rights protected under the Fourteenth Amendment, was overruled by the lower court, and on appeal to the state supreme court the decision was affirmed on the ground that the ordinance was an "ordinary occupational Iicense tax ordinance."7 The United States Supreme Court granted appeal.

Mr. Justice Reed delivered the majority opinion of the hotly contested split decision. He began by observing that the fees in each case were reasonable and not discriminatory. Fortunately, the petitioners did not question the amount.

\section{$6_{\text {Ib1d., p. } 591 .}$ \\ 7 Iold.}


127

involved, for if they did, in the Justice's own words, "to reach a conclusion one would desire to know the estimated volume, the margin of profit, the solicitor's commission, the expense of policing,. . . " 8 etc. The sole constitutional question, according to Reed, was "whether a non-discriminatory Ilcense fee, presumably appropriate in amount, may be imposed upon these activities." 9 In other words, did the pedding action of the petitioners come under the definition of commercial activity?

In delivering the opinion, Reed spent considerable space and time on the right of the court to adjudge acts of men "under color of a constitutional right." 10 The "ordinary requirements of civilized life compel. . .adjustment of interests."Il As if the Court was for the first time handing a case of this nature, Reed continued his apology:

Upon the courts falls the duty of determining the validity of such enactments as may be challenged as unconstitutional by litigants. In dealing with these delicate adjustments, this court denies any place to administrative censorship of ideas or capricious approval of distributors.12

Finally getting down to the issue before the Court, the Justice

$$
\begin{aligned}
& 8_{\text {Ibid., p. } 592 .}
\end{aligned}
$$

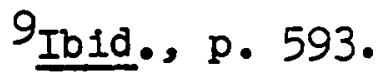

$$
\begin{aligned}
& \text { 10 Ib1d., p. } 594 .
\end{aligned}
$$

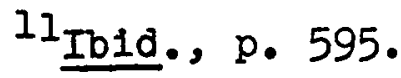

$$
\begin{aligned}
& { }^{12} \text { Ibid. }
\end{aligned}
$$


128

noted that although teachers and preachers of religion depend upon alms and charity for their support as well as for the spread of their views, when the "practitioners of these noble callings choose to utilize the vending of their religious books and tracts as a source of funds, "I3 the commercial nature of such practices cannot be overlooked. Neither is a money-making activity immune from licensing fees because it is not "PURELY commercial."14 "It is enough that money is earned by the sale of articles. A book agent cannot escape a license requirement by a plea that it is a tax on knowledge." 15 What the Justice meant was that the activity of the appeliants in this case if not completely commercial, was commercial enough to be covered by the ordinance and its requirement of a license fee. In applying the ordinance there was then no differentiation between selling commercial and non-commercial literature. Reed further distinguished "between non-commercial literature which is sold and that which is distributed free, denying to the former that degree of protection afforded the latter."16 To the Justice, the power of the state to charge

$$
\begin{aligned}
& 13 \text { Ibid., p. } 595 . \\
& { }^{14} \text { Ibid., Italics supplied. } \\
& 15_{\text {Ibid., pp. 596-597. }}
\end{aligned}
$$

16"Due Process - - Freedom of Expression in non-commercial publications," Michigan Law Review XII (Oct., 1942), p. 324. The author supports the above quoted statement by declaring: "The decision is suprising in the light of the Lovell case, the language of which seemed broad enough to encompass all noncommercial publications regardless of their mode of distribution." p. 325 . 


\section{9}

reasonable fees was a valid exercise even to proponents of religious theories when they use "ordinary commercial methods of sales of articles to raise propaganda funds." 17 There was nothing unusual or odious about "many small towns [having] ordinances requiring peddlers and hawkers to secure a permit before pursuing their business in the town."18 Although Reed himself never made the remark, he has been severely criticized for such reasoning.

It is to be feared that the principal case, in placing Jehovah's Witnesses on the same footing with ordinary peddlers and hawkers, will offer an excellent opportunity to those who seek the suppression of this unpopular minority. 19

The reference here is of course to the possibility of curtailing the activities of the Witnesses by the imposition of burdensome taxes and fees, an argument which is constitutionally groundless. The Justice seemed to have anticipated his critics for he said:

Nor do we believe it can be fairly said that because such proper charges may be expanded into unjustifiable abridgements they are therefore invalid on their face. . . The legislative power of municipalities must yield when abridgement

17 Jones v. Opelika, p. 597.

18 "state Licensing of the Distribution of Literature and Freedom of the Press and of Religion," Fordham Law Review XI (Nov., 1942), p. 309.

19"'States' Police Power -- Licensing Limitations on Freedom of Religion," Virginia Law Review, XXXIX (Dec.,1942), p. 341 . 
is shown. 20

Being aware of the practices in many cities where religious peddlers are permitted to distribute their wares without meeting license requirements, it was the opinion of the majority that the wisdom of some of those communities permitted the poor and the weak to draw support from petty sales of religious books without contributing anything for the use of public facilities. But such an exemption was voluntary, and was not reason to invalidate reasonable license ordinances.

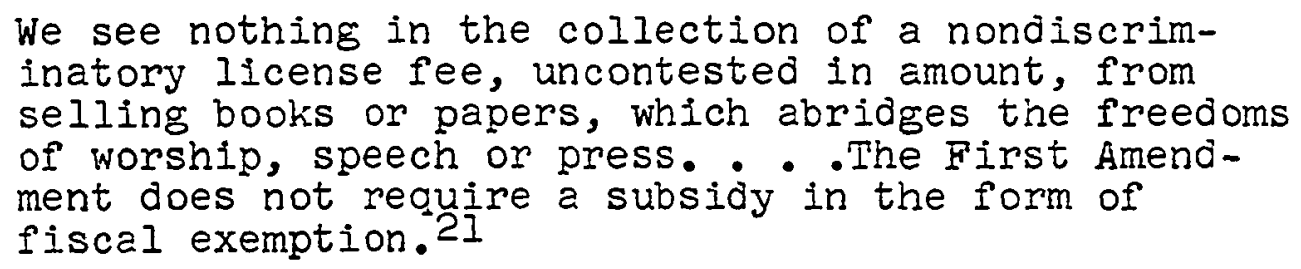

The Court's argument implied very strongly that the profit or loss involved in the sale of Iiterature had no bearing whatsoever on the validity of the ordinance. But the minority and the critics of the decision argued that a nonprofit organization could not by proper definition be included in the meaning of a business. As a practical matter, many groups circulated their ideas freely by distributing free literature. A license tax on these groups would spell their death.

20 Jones v. Opelika, pp. 597-598.

2IIbid. 
131

Since unrestricted circulation of ideas is largely dependent upon the sale of literature to defray the cost of publication, the suggestion of the present. . . court that the tax may be avoided by giving the literature free of charge is without merit.22

The majority refused to look at the action of the appellants as constituting distribution of free literature. "But it is because we view these sales as partaking more of commercial than religious or educational transactions that we find the ordinances, as here presented, valid."23 To those who disagreed with the Court, this was anathema. "Whether petitioner's acts constitute a commercial rather than a religious venture is purely a question of fact. It would be a distortion of the facts of record to say that petitioners were engaged in a commercial venture."24 what the case did, said a critic, was to empower the state to "prohibit those who cannot afford to distribute their pamphlets free from distributing at all."25 To prevent such discrimination, "it is submitted that in cases involving freedom of speech as affected by a tax, the validity of the tax should depend on its

\section{2 "Freedom of Press and Religion -- License Tax on} Periodicals," Washington University Law Quarterly XXVII (Feb., 1942), p. 272.

$$
\begin{aligned}
& 23 \text { Jones v. Opelika, p. } 598 . \\
& 24 \text { Indiana Law Journal, XVIII p. } 315 . \\
& 25 \text { "Licensing and Distribution of Religious Pamphlets," }
\end{aligned}
$$
Chicago-Kent Law Review XX (Sept., 1942), p.352. 
tendency to limit the free circulation of ideas." 1326 However desirable the rule may have been, it was not the responsibility of the Court in the instant case to pass judgment on its merits. Referring to the Lovell case, the court claimed that there was a distinction. The Lovell decision made discretionary control in the area of free speech unconstitutional. "Here we have a very different situation. A license is required that may properly be required."27 In this connection, there was one other important measure which caused much controversy. The Opelika ordinance gave the City Commission the power to revoke the license at will. This arbitrary power, the petitioners contended was invalid, because it constituted censorship even before the license was issued. "But," said-Reed in rejecting the plea, "there has been neither application for, nor revocation of, a license. The complaint was bottomed on sales without a license." 28 And since it did not affect the present case, "there is no occasion, at this time, to pass on the validity of the revocation section." 29 The court therefore decided that one who does not comply with a valid ordinance requiring that he first obtain a license before engaging

26 Washington University Law Quarterly, XXVII p. 272 。 $27_{\text {Jones }}$ v. Opelika, p. 599. 28 Ibid. 29 Ibid. 
in selling religious literature, cannot defend upon the ground that the revocation provision renders the ordinance unconstitutional. "The hazard that the license properly granted would be improperly revoked is far too slight to justify declaring the valid part of the ordinance. . .also unconstitutional."30 The dissenting opinion of Chief Justice Stone -- for constitutional academicians at least -- is important in at least two respects. First; his dissent in two of the most celebrated cases involving Jehovah's Witnesses and civil liberties in general, became law in the course of a short period. In both instances the witnesses were the direct beneficiaries, which has led some to conclude:

On the whole, it must be said that in none of these cases has the court (with the exception of Mr. Justice stone) as yet displayed the burning zeal to protect the freedom, which it had earlier shown in dealing with freedom of speech and of the press. 31

Stone himself acknowledged his gratitude to the witnesses and the role they played in Constitutional Law by remarking that they "ought to have an endowment in view of the aid which they give in solving the legal problems of civil liberties." 32 This is not to say that the Justice was prejudiced unduly by the

30 Ibid., p. 600 .

${ }^{3 I_{G r e e n}}$ Washington University Law Quarterly, XXVIII p. 520 .

${ }^{32}$ Letter from stone to Charles Evans Hughes. Quoted in Mason, Harlan Fiske Stone, p. 598 . 
134

Jehovah's Witnesses in rendering his decisions. On the contrary, taken as a whole, he seems to have been quite objective and certainly consistent. The second contribution had no essential constitutional value, for it was in the coining of a term. It was here that the term "preferred position" was first originated. To be sure, the doctrine was in existence for some time.

Stone's dissenting opinion was based mainly on the ground that the ordinance imposed a flat tax which was prohibited by the Constitution when applied to practices relating to dissemination of ideas. He began by saying that the invalidation of the ordinance should be based on two independent grounds (1) the unconstitutionality of a license revocable at will which acted as a restraint on freedom.

Digging deep into history, stone referred to John Milton and his "appeal for the Liberty of Unlicensed Printing."33 Other writers too delved into history and expressed their views in accordance with what they believed bygone legalists would have said.

Surely the spirits of the departed justices must have been startled to hear the Court declare that the constitution of the United States does not prohibit a substantial revenue-raising tax on the non-commercial distribution of religious and educational books and pamphlets. One present must have

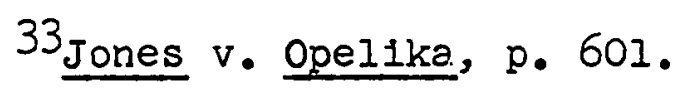


135

wondered what the great Chief Justice John Marshall would have said to $\mathrm{Mr}$. Justice Reed's assertion that a substantial tax is neither abridgement nor prohibition, as he remembered the famous pronouncement that ithe power to tax is [sic] the power to des-

The majority opinion had differentiated the instant case from the Lovell case; but to Stone the similarity was striking. "Indeed the present ordinance is a more callous disregard of the constitutional right than that exhibited in Lovell v. Griffin, supra."35 In the Lovell case, first of all, the defendant might have been issued a license had he applied for it. Secondly, he would not have had to pay a sum of money to obtain a license. The two cases were similar in that in either case the enjoyment of a basic freedom was dependent upon the same contingency. Censorship was effective in both cases.

Nor is any palliative afforded by the assertion that the defendent's failure to apply for a license deprives him of standing to challenge the ordinance because of its revocation provision. . . . 36

It was not significant to stone that the appellant had not applied for a license, for here the ordinance was void on its

34 Chicago-Kent Iaw Review, XX p. 349. Marshali's state-

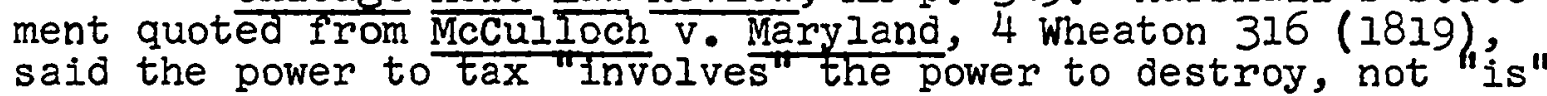
the power to destroy. There is a significant difference in. the two.

35 Jones v. Opelika, p. 602 . 36 Ibid. 


\section{6}

face by making the right of press subject to the "uncontrolled will of public officials." 37

Stone observed and upheld the petitioners' contention that for those persons who are not financiaily able to distribute literature without the solicitation of funds, the ordinance was especially destructive of their freedom of the press. To them, the tax had a cummulative effect, for their town-to-town campaign would be subject to the ordinances of each municipality. The majority's opinion that the tax was "presumably appropriate," "reasonable," "suitably calculated," and "uncontested in amount," Stone felt was "irrelevant to the question now before us."38 Taxing a "non-commercial, non-profit activity devoted exclusively to the dissemination of ideas, educational and religious in character, "39 such as in the case, was invalid. He further differentiated the tax from the fee, the latter being nothing more than a nominal charge to defray expenses of the licensing system. Somewhat surprisingly, stone attacked the amount involved in the opelika case as unreasonable. The ordinance, in addition to the $\$ 10.00$ and $\$ 5.00$ per annum imposed upon peddlers, levied an additional 50 cents insurance fee. This alone said stone was "adequate to defray the cost of administering the license system." 40 In every

\section{Ibid.}

38 Ibid.j p. 604. See Grosjean v. American Press Co., 297 U.S. $233(1936)$.

$$
\begin{aligned}
& { }^{39} \text { IbId. } \\
& 40 \text { Ibid., p. } 605 .
\end{aligned}
$$


case the lower courts had defined the fees as "taxes," and taxes, to stone, were abhorrent when required of those disseminating ldeas.

The Chief Justice carefully pointed out that states may, under police powers, pass regulatory measure in the form of reasonable fees and taxes, but here the tax was not regulatory save as a restraint upon freedom. Regulation should be directed toward police protection and the good order of the community. "Thus the Opelika decision denies the petitioner procedural due process because the petitioner's activities did not injure or threaten to injure public health, safety or morals."4I Indeed, police powers must have a reasonable bearing to injury of some sort. 42 "The license and fees provided by the tax

4I"Another Jehovah's Witnesses Case," Indiana Law Journal XVII (Aug., 1942), p. 560.

42"The police power is the legal capacity of government to control the personal liberty of individuals for the protection of the social interests (common good)..." Willis Hugh Evander, Constitutional Law of the United States (Bloomington: The Principia Press, 1936), $\bar{p}_{\text {. }} 225$. There remains unsurrendered by each state, that inherent force, essential to a sovereign government called "police power." Northwest Fertilizing Company v. Hyde Park 97 U.S. 659 (1878). It is the power to provide for the health, safety, morals and general welfare of the entire people, as against the interest of a few. Miller v. Schoene 276 U.S. 272 (1928), Munn v. Illinois, supra. Marking the limits placed upon police power by constitutional guarantees has occupied the attention of the courts for generations, for police power can never justify a violation of the express prohibitions of the constitution (see Stone's dissent above). Panhandle Eastern Pipeline Company v. Highway Commission, 294 U.S. $013(1935)$, Buchanan v Warley, supra. Its exercise cannot be unreasonable or arbitrary, Nashville coal and st. Louis Rallway v. Walters, 294 U.S. $405^{\circ}$ (1935) Graves v. MInnesota 272 U.S. 425 (1926), despite the state's wide discretion. Terrace v. Thompson, 263 U.S. 197 (1923). Yet within its legal sphere, 
ordinance of the City of Opelika bears no relationship to the danger which may be prohibited by the exercise of police powers." 43

In all fairness to the majority and to stone, it must be said that inasmuch as the court has never followed a clear and consistent rule regarding taxing powers for police purposes, 44 the validity of an ordinance which imposed a tax to regulate distribution of literature could not be easily adjudged.

The majority view that the petitioners' activities were more commercial than religious in nature facilitated the ballancing of freedom of religion against the needs of revenue.

the wisdom of state action cannot be questioned by federal authority. Patterson v. Kentucky, 97 U.S. 501 (1878). See "Freedom of Religion, speech, and Press -- non-discriminatory license fees for Sellers of Religious Books," Brooklyn Law Review XII (oct., 1942), p. 72 .

43Ibid., p. 556. There are three tests which have been used to determine when police power can be properly exercised to control speech and press. (1) When the words used directly urge or cause unlawful acts, Masses Publishing Company v. Patten, 244 Ped. 535 (1917); (2) When such words have an indirect or remote tendency to cause such unlawful acts, Pierce v. United States, 252 U.S. 239 (1920), Gitlow v. New York, supra; (3) When there is a "clear and present danger" that the words used will cause such unlawful acts, Schenck v. United States, supra. Cf. "Use of Taxation and Licensing in Suppression of Freedom of Religion and the Press," pp. 168-175.

44 To list but a few cases, originally the taxing power could be used. Veazie Bank v. Penno, 8 wall. 533 (1869), Mccray v. United States 195 U.S. 27 (1904); but in Bailey v. DrexeI Furniture company, 259 U.S. 20 (1922), the power was denied. In UnIted States V. Butler, 297 U.S. I (1936), the Court appears to have approved a limited use of the taxing power for police power purposes. 
139

The type of peddling license involved in the instant case usually serves a dual purpose: to raise revenue, and to protect local businesses from outside competition. Since the activities here indulged in do not pertain to the latter, the requirement of license fees seems justifiable only as a means of fulfiling fiscal needs. 45

Mr. Justice Stone's dissent was based in part, against this reasoning. The ordinance was invalid whether the tax required was for the purpose of meeting fiscal needs or regulating peddling activities. In the instant case there was no need for the former and no justification for the latter. In a separate dissenting opinion Mr. Justice Murphy went further on this particular issue for he said:

The taxes here involved are ostensibly for revenue purposes; they are not regulatory fees. Respondents do not show that the instant activities of Jehovah's Witnesses create special problems causing a drain on the municipal coffers, or that these taxes are commensurate with any expenses entailed by the presence of the Witnesses. 46

"It Iends no support," said Stone, "to the present tax to insist that its restraint on free speech and religion is non-discriminatory. "47 He then proceeded to differentiate certain rights and freedoms and recorded in his dissent the

45 n $_{\text {Freedom of Religion -- Right to Impose a License Tax }}$ Upon Dissemination of Religious Literature," Columbia Law Review, XIII (Sept., 1942), p. 1201.

46 Jones v. Opelika, p. 620.

47 Ibid., p. 608 . 
140

most oft-quoted passage from the case.

The First Amendment is not confined to safeguarding freedom of speech and freedom of religion against discriminatory attempts to wipe them out. On the contrary, the Constitution, by virtue of the First and the Fourteenth Amendments, has put those freedoms in a PREFERRED POSITION. - . Their commands. . .extend at least to every form of taxation which, because it is a condition of the exercise of the privilege, 48 capable of being used to control or suppress it. 48

Stone felt that if the petitioners' activities were taxable at all -- and he was not willing to grant this -- then they would be taxable on the funds solicited. But there was no profit for one thing, and more important, the solicitation of funds was for religious purposes, "and the present taxes are in no way gauged to the receipts." 49 To Stone, it was

- . fairly obvious that if the present taxes, laid in small communities upon peripatetic religious propagandists are to be sustained, a way has been found for the effective suppression of speech and press and religion despite constitutional guarantees. . .

In its potency as a prior restraint on publication, the flat ifense tax falls short only of outright censorship or suppression. 50

Mr. Justice Reed's statement, "it is enough that money is earned from the sale of articles, " 51 of necessity distinguished between taxes on the free distribution or the sale of literature at cost, and those on its sale at a profit.

$$
\begin{aligned}
& \text { 48 Ib1d. Italics supplied. } \\
& { }^{49} \text { Ib1d., p. } 609 . \\
& 50 \text { Ibid., pp. 610-611. } \\
& \text { 51 Ibid., pp. 596-597. }
\end{aligned}
$$


141

This distinction would seem at first sight a proper one, for if money is earned, taxes can be paid with earnings. Freedom of the press will not be jeopardized, nor will anyone be deprived of its enjoyment because of his economic position. But the difficulty is that all taxes are not alike. The argument applies only to taxes measured by net income. Flat taxes such as those in the present case, and taxes measured by gross income may obstruct the activities of the press and so restrict its freedom. . .52

Because the Jehovah's Witnesses are a religious group and there is no profit-making motive in their distribution of literature, "the fallacy of the majority opinion seems to rest in its view that the Jehovah's Witnesses activities had a commercial motive."53 For purely evangelistic purposes, the literature was concededly distributed at a loss, "so that the decision would seem to reach the result of limiting the freedoms of press and -eligion exclusively to those who can afford to publish and circulate printed matter without charge."54 By proper definition:

- . Jehovah's Witnesses are no more peddlers than the ordinary minister who preaches a sermon from the pulpit and passes the collection plate. Without procurement of money in a non-profit exchange for their pamphlets It is doubtful whether the witnesses could continue to spread their religious ideas... .55

52yale Law Journal, III p. 173.

53"Freedom of Speech, Press and Religion -- Application of License Tax for Distribution of Religious Iiterature," Minnesota Law Review XXVIII (Dec., 1942), p. 92.

${ }^{54}$ Ibid.

55 Virginia Law Review, XXIX p. 340. 
142

The separate dissenting opinion of Mr. Justice Murphy dealt mainly with the historic importance of permitting free dissemination of ideas especially when the ideas are being propagated by religious zealots. He pointed out repeatedly that the petitioners were ministers of the gospel and "were evangelizing their faith as they saw it." 56 certainly there was no suggestion or intimation whatsoever that "in any of these three cases petitioners were perpetrating a fraud, that they were demeaning themselves in an obnoxious manner." 57 Relying on the Lovell and Schneider cases, Murphy felt that if the distribution of pamphlets from house-to-house for noncommercial purposes is protected from prior restraint or censorship, "so should it be protected from the burden of taxation." 58 with stone, he actually felt that the amount of tax imposed by the ordinances in question was burdensome. Since the opinion of the Court held all the taxes as "substantial," it led to one conclusion; "that they prohibit or seriously hinder the distribution of petitioners' religious literature."59 The main issue was, however, "whatever the amount, the taxes are in reality taxes upon the dissemination

56 Jones v. Opelika, p. 612.

57 Ibid., p. 613. Essentially the same argument was advanced in Indiana Law Journal, XVII p. 557.

58 Ibid., p. 615.

59 Ib1d. 
143

of religious ideas. . The petitioners should not be subject to such tribute." 60

Early American history, Murphy noted, records the harsh treatment of religious dissidents. The Constitution was instituted to guarantee the dissenters freedom from suppression by the majority as well as by governmental authority. The Jehovah's Witnesses were no more than a new sect of itinerant zealots whose right to engage in non-commercial activities was being seriously hindered by onerous taxes. Then Murphy too, made his literary contribution to the hall of constitutional quotations.

If this Court is to err in evaluating claims that freedom of speech, freedom of the press, and freedom of religion have been invaded, far better that it err in being overprotective of these precious rights.61

This statement was given public endorsement by several writers. One of them said, "Wwe are] in full concurrence with Justice Murphy's masterly summation of the basic issue and the responsibility of the brethren." 62

The most notable feature of the other dissenting opinion by Justice Black and Douglas concurred in by Justice Murphy, was their "regret" over the Gobitis decision (discussed below).

60 Ibid., p. 616.

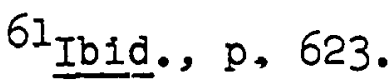

62 Arthur Krock, "Minorities Rights in the supreme Court," New York Times (June il, 1942), p. 21. 
144

Other than exploiting the opportunity to record their apologies, Black and Douglas registered their dissent in the instant case on the ground that the court sanctioned "a device which. - . suppresses or tends to suppress the free exercise of religion as practiced by a minority group."63 Mr. Justice Douglas, some years later wrote that the religious freedom which the First Amendment protects has many facets. In all, the Justice listed twelve. The following two are most pertinent:

9. Religious liberty includes not only the conventional methods of worship but the unorthodox as well, such as distributing religious literature from door to door.

10. No license may be exacted by the state for the performance of any religious exercise nor a tax imposed on it. 64

Public reaction to the Opelika decision was as immediate as it was intensely one-sided, Unlike Gobitis however, the reaction to the Opelika case was almost completely from the press and writers in general. "The majority of the editorials expressed dissatisfaction with the results reached."65

The Opelika decision -- so called after the town in Alabama which was the first of a group of three municipalities to apply: peddler's licensing requirements to the distribution of religious leaflets by the Jehovah's Witnesses -- had been

63 Jones v. Opelika, p. 623.

64william 0. Douglas The Right of the People (New York: Doubleday and Company Inc, $1 9 5 8 \longdiv { , }, \mathrm{p}$. $\frac{139}{139}$

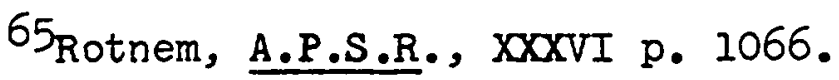




\section{5}

condemned in the press almost without exception as a violation of constitutional guarantees of freedom of religion, of speech and of the press. 66

The press reports and the articles in periodicals and journals forsook straight-reporting and engaged more than ever in editorializing. Never were there so many outspoken champions of constitutional rights. It was heartening to note that there were so many defenders of such an unpopular sect as the Jehovah's Witnesses. 67 The general attack against the court was blunt as it was subtle:

As Thomas Reed Powell intoned solemnly to us one day in Langdell Hall at Harvard after a 1939 decision had invalidated a considerable portion of his course in Constitutional Law: 'The court giveth and the count taketh away; blessed be the name of the Court. 168

The indignation expressed by the public against the Opelika decision not unlike the dissenting opinions, fell generally into two areas. (1) Suppression of speech and press by a license tax, and, (2) the power of uncontrolled revocation in a commission. Under the first point, the court has held

66Irving Dillard, "Salute to the Supreme Court," New Republic CVIII (March 1, 1943), p. 276. See also: "ConstiEutionality of an Ordinance Requiring People Disseminating and Selling Religious Pamphlets to Pay a License Fee," University of Pennsylvania Law Review XCI (Aug., 1942), pp. 75-76; "Onimous Decision, Time, XXXIX (June 22, 1942), pp. 55-56; and Moley, "The Boot is on the other Leg," p. 68. 67 Rotnem, A.P.S.R., XXXVI p. 1066. $68_{\text {Quoted in Dillard, New Republic, }}$ CVIII, p. 276. 
previously69 a licensing statute which is a lawful exercise of regulatory powers may not be attacked in anticipation of its improper administration. "But when a statute is invalid on its face, this rule for obvious reasons does not apply."70 The contention of the majority was that the ordinance imposed merely a fee. The publication or circulation, for religious purposes or otherwise, of newspapers, pamphlets, periodicals and other vehidies of information and opinion, "is plainly not immune faom ordinary taxes for the support of the government."71 However, the opposition felt that "the fee in question was not of that character. The license imposed flat fees payable in advance. - To impose a license fee upon the dissemination of information is neither socially necessary nor desirable."72 The result of the Hamilton and Gobitis cases to which the majority made several references was questionable in terms of the validity of the present licensing ordinances. Black and Douglas felt one wrong step was being followed by another. Others were willing to grant that while the Hamilton and Gobitis cases could perhaps be defended, the Opelika decision was quite

69smith v. Cahoon, Lovell v. Griffin, Thornhill v. A labama, supra; and Lehon v. AtIanta, 242 U.S. 53 (1916).

70 Yale Law Journal, LII p. 171.

71 Ibid., p. 172 .

$72^{n}$ Civil Liberties -- Freedom of Religion, Press and Speech -- Licensing Ordinances," George Washington Law Review XI (Dec., 1942), p. 116. 
-. . for Jones v. Opelika there is nothing to be said. There was nothing to be balanced against the freedom except the tax revenue, which, even if it were a proper object to be placed in the scales, was here non-existent, because the taxes were greater than could have been paid. 73

Under the second point, "The arbitrary revocation feature of the Opelika ordinance, the majority held, was not an issue because there had been no revocation."74 But with this reasoning neither the dissenting Justices nor the public in general went along.

Previous decisions have held that unlimited discretion vested in an official agency to grait or refuse licenses of this kind renders the ordinance unconstitutional [Lovell, Cantwell and Cox cases cited here]. In declining to review the converse question of administrative discretion to revoke licenses, because petitioner had not applied for a license, the Court follows the rulings in ordinary license cases, but is inconsistent with those involving civil liberties where no license was required to be sought to raise the issue of constitutionality. It would seem that the decision is wrong in this respect, since the power to revoke a license appears as great a threat of censorship as the power to deny one in the first instance. 75

Narrowed down to a general proposition, the criticism against the majority opinion centered on the unreasonable extent to which the court had gone in restricting civil liberties.

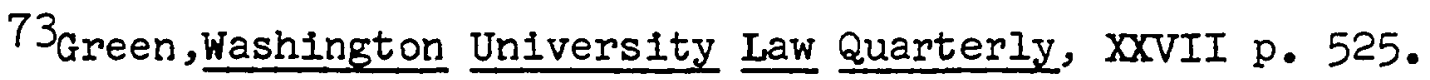
${ }^{74}$ Chicago-Kent Law Review, XX p. 351 . 75 Columbia Law Review, XLII pp. 1200-1201. 
148

"The principle case indicates a tendency. . . to pull civil rights more into line with economic rights by applying a presumption in favor of legislation. . "76 Because the court in the instant case was willing to regulate non-commercial activity by bringing it under the scope of commercial taxing measures, "this spells a significant weakening of the protection previously accorded civil liberties."77 Even among those who look upon the Jehovah's Witnesses with contempt and derision have noted, although they resort "to the contemptible device of arousing prejudice against other recognized religious denominations, "78 it must be admitted that in the Opelika decision, "the Court has conceived a dangerous vehicle that might be used to destroy freedom of worship."79

The Opelika decision, as would be expected, endorsed and authorized municipalities to invoke licensing ordinances upon distributor of religious literature, namely, the Jehovah's Witnesses. Immediately there followed a flood of suits and challenges before the courts. The Witnesses themselves aware of the doctrine of reasonable doubt inherent in all split decisions intensified their campaign. Jones v. Opelika was

76 "Due Process -- Freedom of Expression in Non-commercial Publications," Michigan Law Review XLI (Oct., 1942), p. 324.

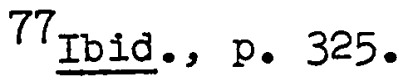

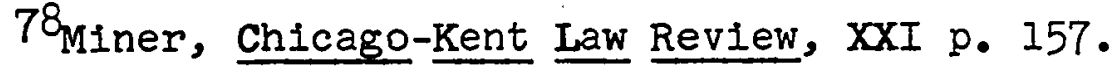

79 Ibid., p. 169. 
appealed for a rehearing. 80 This time Mr. Justice Douglas delivered the per curiam decision reversing the judgments of the state courts on the basis of the decision reached in Murdock v. Pennsylvania ${ }^{81}$ on the same day. What the Barnette case was to the Gobitis case, 82 the Murdock case was to Opelika. Even the Justices divided identically in both the Barnette and Murdock cases from their previous counterparts. In overturning a previous decision, no doubt the Murdock case was significant; but not to the extent that some have prematurely pointed out.

This generation has seen no comparable reversal - - Even the historic switch of the Court on state minimum-wage laws in the midst of the battle over the President's ill-starred Supreme Court enlargement bill is not comparable. 83

80Reargument was admitted March 10, 1943, and the decision was reached on May 3, 1943. 319 U.S. 103. Briefs of amici curiae were filed by the American Civil Liberties Union and the General Conference of Seventh-Day Adventists in support of a rehearing and urging reversal.

81319 U.S. 105 (1943). This case was heard and decided together with seven other cases, each one arising from the same municipality. Perisich v. Pennsylvania (City of Jeannette); Seders v. Pennsylvania (City of Jeannette); Mowder v. Pennsylvania (City of Jeannette); Lamborn v. Pennsylvania (City of Jeannette); Maltezos v. Pennsylvania (City of Jeannette); Anastasia Tzanes $v$. Pennsyivania (City of Jeannette); and Eliaine Tranes $v$. Pennsylvania (City of Jeannette).

${ }^{82}$ Discussed in Chapter VII.

83"About-Face to Freedom," New Republic CVIII (May, 24, 1943), p. 693. The cases referred to here are obviously Adkins V. Children's Hospital 261 U.S. 525 (1923), and West Coast Hotel Company $v$ Parrish, 300 U.S. 379 (I937). 
150

A reversal of a constitutional decision is never a trivial matter, but some go through a long and difficult period of politics and litigation, such as in the case of minimum wages and maximum hours laws; while others, as illustrated by the present license tax cases, are overturned immediately. Whatever the reasons involved in this "legal fiction," suffice It here to say that the court is not specially fond of overturning a previous decision. In fact, the court is quite wary and often hesitates in vacating a previous judgment.

The case of Murdock v. PennsyIvania 84 came to the supreme court on a writ of certiorari to review the affirmances of orders in eight cases arising in the City of Jeannette Pennsylvania, which refused to permit appeals for violations of municipal ordinances. Except for the number and frequency of violations involved, the facts of the case were not unlike those in the Opelika case.

The City ordinance required solicitors to take out a license before peddling their merchandise. The fees were $\$ 1.50$ for one day, $\$ 7.00$ for one week, $\$ 12.00$ for two weeks, and $\$ 20.00$ for three weeks. The Petitioners, Jehovah's Witnesses, went from door to door soliciting the people to "purchase" certain religious books and pamphlets without first procuring a license. Two religious books, "Salvation" and "Creation" were actually sold. The prices they quoted were twentyfive cents for each book and five cents for a pamphlet. But

84319 U.S. 105 (1943). 
151

they would and did take less on occasion, for what they sought was a "contribution" rather than an actual "purchase."

Petitioners paid three cents each for the pamphlets and, if they devoted only spare time to the work, twenty cents each for the books. Those devoting full time to the work acquired the books for twenty-five cents. There was evidence that some of the petitioners paid the difference between the sales price and the cost of the books to their logal congregations which distributed the literature. 85

The petitioners were convinced and fined for violation of the city ordinance. The judgment was sustained by the supreme Court of Pennsylvania. On a motion of certiorari the Supreme Court reviewed the case with seven other cases and at the same time granted a rehearing on Jones v. Opelika.

speaking for the majority composed of the dissenters in the Opelika case, Black, Stone, and Murphy, joined by Rutledge who had been appointed to the bench only a couple of months before, Justice Douglas gave a short course on the importance of free religious activity. He made it clear, by being repetitious, that rights are not absolute and freedom of religion and the press are not "free from all financial burdens of the government." 86 But this was a flat tax levied "as a condition to the pursuit of activities whose enjoyment is guaranteed by the First Amendment," 87 or "as a condition precedent to the

$$
\begin{aligned}
& { }^{85} 5_{\text {Ibid., p. } 107, \text { n. } 2 .} \\
& 86_{\text {Ibid. }} \text { p. } 112 . \\
& 87_{\text {Ibid., p. } 114 .}
\end{aligned}
$$


exercise of the constitutional privileges." 88 Reminiscent of Marshall's classic remark in McCulloch v. Maryland, 89 Douglas too rendered a choice remark; "The power to tax the exercise of a privilege is the power to control or suppress its enjoyment."90 Although "Jehovah's Witnesses are not 'above the law, "9l they are members of a religious sect whose reasonable activities are protected from infringement by certain regulatory measures. The Constitution especially prohibits a community from suppressing or imposing a tax on "the dissemination of views because they are unpopular, annoying or distasteful." 92 The power to tax a religious practice is not only a violation of the Constitution, it would permit the taxing authority to deprive an unpopular sect of the resources necessary for its maintenance. "Those who can tax the privilege of engaging in this form of missionary evangelism can close Its doors to all those who do not have a full purse."93

To Mr. Justice Douglas the case presented only one issue, "the constitutionality of an ordinance: which as construed and applied requires religious colporteurs to pay a license tax as

88 Indiana Law Journal, XVIII p. 314.

${ }^{89}$ see n. 34.

90Murdock v. Pennsylvania, p. 112.

$91_{\text {Ib1d. , p. } 116 .}$

92 Ib1d.

93 Ib1d., p. 112 . 
a condition to the pursuit of their activities." 94 As a sidelight, it is somewhat surprising that the term "colporteur" was not used previously in cases dealing with them. Douglas made reference to the term several times in the instant case. So much so that some must have felt the Justice had originated it.

It is significant that a separate and distinct word has been developed in the English language for one who distributes religious tracts and books -- 'colporteur'. - . The Court says that it is a combination both of preaching and of distribution of religlous literature, being more than either separately. The religious activities of the colporteurs have as much claim to freedom and protection as the more orthodox and conventional exercise of religion, and they may also claim the same guarantees of freedom of speech, and of reIigion as the others.95

Indeed, It is not the method of disseminating ideas that makes one group subject to laws from which others are exempt.

- the mere fact that the religious literature is 'sold' by itinerant preachers rather than 'donated' does not transform evangelism into a commerclal enterprise. If it did, then the passing of the collection plate in church would make the church service a commercial project. 96

Furthermore, no matter how misguided or intolerant an itinerant

94 Ibid., p. 110.

95Harold Pressley Jr. "Expanding Civil Liberties in the supreme Court," Texas Iaw Review XXII (Feb., 1944), pp. 230-231. 96 Murdock v. Pennsylvania, p. 111 . 
154

preacher may be, he "does not become a mere book agent by selling the Bible or religious tracts to help defray his expenses or to sustain him."97

Douglas carefully elaborated on colportage as an ageold method of evangelism which had a "high claim to constitutional protection as the more orthodox types."98 He admitted however the manner in which it was carried about sometimes created special problems with which the state had the authority to deal, as evidenced in the Cox and Chaplinsky cases. But this was merely a corroboration of his argument that the rights under consideration were not absolute. This case however, presented no such unusual problems. It was plainly a flat tax on an activity the free access to which was guaranteed by the First Amendment. The police power of the state had nothing to deal with here. The Justice noted that first; there was no breach of the peace. The solicitation was done peacefully without incident. Secondly; there was no use of obscene language, certainly none that would have incited retaliation. Thirdly; there was no use of streets or public places to the extent that the state was compelled to afford safety, comfort, and protection. Fourthly; the oroinance was not narrowly drawn to safeguard the public from the evils of solicitation. There was no restriction as to time, place and manner, only a

$$
\begin{aligned}
& 97 \text { Ibid. } \\
& 98 \text { Ibid., p. } 110 .
\end{aligned}
$$


tax ordinance which flatly denied any and all activity unless the fee was paid.

The contention that the ordinance imposed a nominal fee, the Court rejected. As presented in Mr. Justice Stone's dissenting opinion in the opelika case, the Court said in relation to the matter of defraying expenses and reasonable regulatory measures, the fees imposed were exhorbitant, There was no way to justify such an unrelated amount, even if the ordinance itself were constitutional -- which the court was not willing to grant.

The argument that the ordinance was nondiscriminatory, the court did not accept as material. "The protection afforded by the First Amendment is not so restricted."99 said Douglas. Equality of treatment had nothing to do with the validity of the ordinance. Felying on the statement made popular by stone in the Opelika case Douglas pontificated, "Freedom of press, freedom of speech, freedom of religion are in a preferred position." 100

The opinion of Mr. Justice Douglas offered enviable style and many quotable phrases; for this, readers will forever be indebted. But in terms of constitutional law, there appears only one significant determination. That the requirement of a license fee for the distribution and sale of religious

99 Ibid., p. 115. 100 Ibid. 
156

literature is a denial of the freedom of press and freedom of religion as guaranteed by the First Amendment. While the Court has not said so, the opinion seems to imply that the constitutional rights of the solicitors and distributors will be upheld as long as the amount involved in the solicitation is within reasonable limits. In other words, if the endeavor is to be classified as non-commercial, so as to be immune from the licensing ordinance, it must also be nonprofit-making. What constitutes profit-making the court has never explained.

The relatively lengthy dissenting opinion of Mr. Justice Reed was based primarily on the notion that the power to impose a licensing tax on solicitation was a matter for the states to settle. He made it plain at the outset that his dissent did not (1) "deal with an objection which theoretically could be made in each case, to wit, that the licenses are so excessive in amount as to be prohibitory, "10I (2) neither did it "deal with discrimination against petitioners, as individuals or as members of the group, calling themselves Jehovah's Witnesses."102 The Justice also took the early opportunity to chide the majority for being susceptible to the cause of the petitioners in their contention that the solicitation was small if accepted at all. "The pittance sought," said Reed, "as

$$
\begin{aligned}
& { }^{101} \text { Ibid., p. } 118 . \\
& { }^{102} \text { Ibid. }
\end{aligned}
$$




\section{7}

well as the practice of leaving books with poor people without cost, gives strength to [their] argument."103 To the Justice there was conclusive evidence that the petitioners approached a prospect with the intent of selling their articles. Only rarely did they leave their books without payment. "The quid pro quo is demanded." 204 It was enough that the plan of national distribution by the watchtower Bible and Tract Society was geared to a sales technique which was so characterized by the state courts.
However high the purpose or noble the aims of the Witness, the transaction has been found by the state courts to be a sale under their ordinances and, though our doubt was greater than it is, the state's conclusion would influence us to follow its determination.105

The presumption of validity of legislation not novel to Court practices was justified according to Reed on the ground that the Court's inclination to invalidate the action was itself questionable. The Court's doubt over the validity of the ordinances was not strong enough to nullify the momentous consideration usually accorded legislative presumption.

The dissenting opinion was also conditioned by the precedence of history. Much time and space were spent in citing and recording the numerous debates of the Constitutional

$$
\begin{aligned}
& 103_{\text {Ibid., p. } 119 .} \\
& 104 \text { Ibid. } \\
& 105_{\text {Ibid. }}
\end{aligned}
$$




\section{8}

Convention. Various state constitutions and resolutions were also presented in support of the contention that although these measures were undoubtedly in favor of religious freecom, in no case was there any indication that the interference with religious practices by taxation was prohibited. Rather, the guarantee was for the right to believe and to be heard. As a rhetorical question:

Is subjection to nondiscriminatory, nonexcessive taxation in the distribution of religious literature, a prohibition of the exercise of religion or an abridgement of the freedom of the press?106

Nothing in the records, said Reed, would lead to the conclusion that such an exemption was intended by the framers of the Bill of Rights. Of the many states proposing amendments to be incorporated into the Bill of Rights, there was no suggestion that taxation either of religious bodies or their evangelism would be prohibited. "This was not because freedom of religion or free speech was not understood. It was because the subjects were looked upon from standpoints entirely distinct from taxation."107

Employing a bit of logic, it was the opinion of Reed that the prohibition of taxation on religious activities if desired, would have been spelled out specifically in the Constitution. Neither the early Colonists nor the framers

$$
\begin{aligned}
& 106_{\text {Ibid., p. } 121 .} \\
& 107 \text { Ib1d., pp. 122-123. }
\end{aligned}
$$


159

of the Constitution were unaware of the problem of taxation and the many abuses inflicted upon them. The English history with which these men were acquainted was a record of obnoxious taxation measures. This alone was convincing proof to Reed that if there had been any intent by the writers and the ratifiers of the Constitution to prohibit taxation, it would have been clearly and precisely stated. He was willing to grant however, religious societies were and should be exempt from undue taxes bit their exemptions from taxation should depend on "state constitutions or general statutes, not upon the Federal Constitution." 108

The First Amendment to the Federal Constitution provides for free press as well as for freedom of religion. Therefore, it seemed strange to Reed that exemption from taxation was accorded religious practices while the newspapers were not similarly exempt.109 still more strange was the fact that, "It has never been thought before that freedom from taxation was a perquisite attaching to the privileges of the First Amendment." 110

The argument that the tax may be used to restrict the dissemination of ideas, Reed was not willing to accept as a ground for discounting the ordinances. ". . . the possibility

108 Ibid., p. 128.

109cf. Grosjean v. American Press Company, supra, and Giragi v. Moore, 301 U.s. 670 (1937).

110Murdock v. Pennsylvania, p. 130. 
of misuse does not make a tax unconstitutional, "Ill he said.

Every power of taxation or regulation is capable of abuse. Each one, to some extent, prohibits the free exercise of religion and abridges the freedom of the press, but that is hardly a reason for denying the power. If the tax is used oppressively, the law will protect the victims of such action. 112

It was unthinkable to Reed that the First Amendment could be stretched so far as to include the sale of pamphlets and books as a religious practice. Just because the books offered for sale were entitled, or dealt with, "Creation" and "Salvation" did not make the itinerant colporteur perform a religious rite. When a monetary price was asked for a book, the evangelist making the sale, "becomes also a book agent."1I3 The rites protected by the First Amendment are "prayer, mass, sermons, sacrament -- not sales of religious goods."114 Reed's opponents have argued, to accept this "fixed definition," would be to "freeze" religion; for what may appear spiritual and godly to one sect or person may be secular or satanic to another. 115 In concluding his remarks, Reed thought the majority erred in vacating the judgment of the Opelika case, because

\footnotetext{
1IIIbid.

112 Ibid.

113 Ibid., p. 132 .

114 Ibid.

115Konvitz, Fundamental Liberties of a Free People, p. 207 .
} 
161

it dealt mainly with abuses, when in fact the issue was over power. Thus the withdrawal of the power of taxation from the state -- "an unfortunate principle of tax exemption"ll6_- would be "capable of indefinite extension."117

Justices Roberts, Jackson, and Frankfurter joined the dissent, but Frankfurter felt compelled to write a separate dissenting opinion. In his inimitabie fashion he began by distinguishing "between the questions that are before us in these cases and those that are not."118 As did Reed, he first of all observed that there was before the court no contention that the amount of taxes was excessive; had this claim been made, the issues to be settled would be very different. Secondly; there was no occasion to consider the measures on the ground that they were unjustly or discriminatorily applied against the petitioners. Counsel did not and could not rightfully claim that the ordinance sought to discriminate against religious groups only or in particular the Jehovah's Witnesses. The question before the court then, was in the petitioners' claim that they were immune from taxation of any kind in their occupation. There was no claim of abuse, discrimination or unreasonable requirements, only that a tax -- no matter how trifling -- imposed on the distribution and sale

116 Murdock v. Pennsylvania, p. 133.

117 Ib1d.

118 Ibid., p. 134 . 
162

of religious literature was a denial of constitutional guarantees. "That is the only question raised in or decided by the state courts; and that is the only question presented to us." 119

Frankfurter noted that if the petitioners could claim tax exemption merely on the ground that they were engaged in religious activity, then the income of clergymen could likewise be claimed for exemption. As if to remind the "Chosen of God" that they too were no worse -- certainly no better -than the rest of his creations, the Justice intoned, "A Clergyman, no less than a judge, is a citizen."l20. Those who preach the Word of God have a like share in the community and are responsible for the costs of the benefits provided by the government. "Plainly, a tax measure is not invalid under the Federal Constitution merely jecause it falls upon persons engaged in activities of a religious nature." 121

There was no denial that the First Amendment afforded certain guarantees such as the right to publish a newspaper, magazine, or a book, but to Frankfurter, the crucial question was, "how much protection does the Amendment give, and against what is the right protected?"122 Freedom of the press does

$$
\begin{aligned}
& { }^{119} \text { Ibid. } \\
& 120 \text { Ibid., p. } 135 . \\
& 121 \text { Ibid. } \\
& 122 \text { Ibid., p. } 136 .
\end{aligned}
$$


not mean exemption from taxation. Even the flat license tax which is condemned by the majority is not reason enough to invalidate the ordinances. The legislature can tax all who engage in an activity provided that it is done on an equal basis. And occupation taxes normally were flat taxes. Constitutionally differentiation need not be made among taxpayers upon the size of their incomes or the extent of their activities.

$$
\begin{aligned}
& \text { Nor, as I have indicated, can a tax be invalidated } \\
& \text { because the exercise of a constitutional privilege } \\
& \text { is conditioned upon its payment. It depends upon } \\
& \text { the nature of the condition that is imposed, its } \\
& \text { justification, and the extent to which it hinders } \\
& \text { or restricts the exercise of the privilege. I23 }
\end{aligned}
$$

Somehow, a careful analysis of this statement would tend to support the view that Frankfurter was not so technically legalistic as in some of his other decisions and the original argument of this dissent seem to indicate. While it is hardiy a fair description of the Justice, perhaps this sort of reasoning led someone to say that "Group interests bulk large in the Justice's philosophy. This orientation tends to make him sensitive to 'social engineering' and a good deal of sociological thinking." 124 Whatever the motivation for such a conclusion, Frankfurter felt that neither the petitioners

123 Ibid. 58.

124Thomas, Felix Frankfurter: Scholar on the Bench, p. 
164

nor the majority had presented sufficient cause to declare the statute vold on the basis of the simple question before the court. The feeling of the majority that those who exercise the power to tax had the power to deprive the petitioners of further activity, he said, was an abstract proposition. Because power may be wielded in tyrannical fashion did not mean that every exercise of power was an expression of tyranny •

To deny constitutional power to secular authority merely because of the possibility of its abuse is as valid as to deny the basis of spiritual authority because those in whom it is temporarily vested may misuse it. 125

Foolish was it indeed to anticipate abuses before they took place. Quoting Justice Holmes who had modified Chief Justice John Marshall's classic statement, Frankfurter said, "The power to tax is not the power to destroy while this Court sits."126 Abuses may be dealt with as they arise, and there were proper remedies. The invalidation of a statute on the ground that abuse was possible -- or probable -- was certainly not a proper remedy.

The reasoning in the two dissenting opinions was similar except on one important point. While Reed's opinion did not

125 Murdock v. Pennsylvania, p. 138.

126 Justice Holmes' modification of Marshall's remark was made in Panhandle Oil Company v. Knox, 277 U.S. (1928), p. 223. 
165

mention it, to Frankfurter there was no differentiation between the so-called regulatory fee and a tax imposed for revenue purposes. "As a matter of public finance," he said, "it is often impossible to determine with nicety the governmental expenditures attributable to particular activities."127 Thus to Frankfurter, it did not matter whether the petitioners were opposed to taxes imposed to regulate activity, or fees levied to realize revenue.

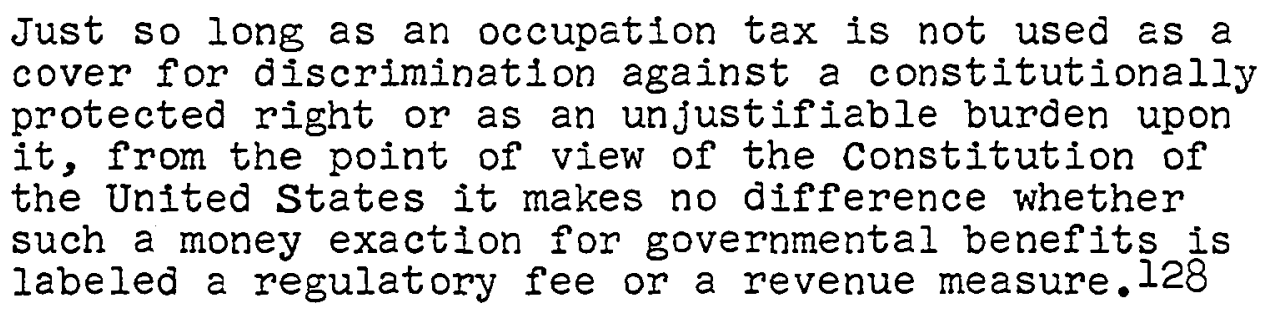

If any discrimination existed at all, as he had pointed out in the flag salute cases, the discrimination was against the majority. Displaying his usual facility with the use of words Frankfurter concluded that the preferred position accorded religious practices in matters of taxation over and against secular practices with similar authority made available by the First Amendment:

- . is to say that the Constitution requires not that the dissemination of ideas in the interest of religion shall be free but that it shall be

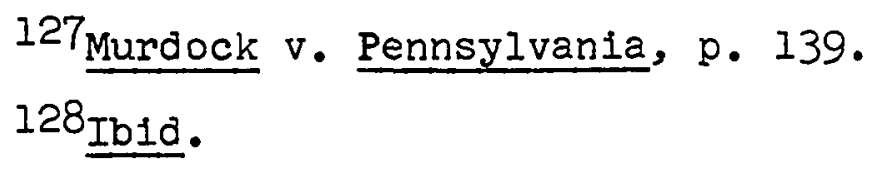


166

subsidized by the state. Such a claim offends the most Important of all aspects of religious freedom in this country namely, that of separation of church and state. 129

To Mr. Justice Frankfurter it has always been difficult to understand why individuals living in a community enjoying all the privileges and benefits that community bestows upon its citizens, would dare to refuse to comply with ordinary rules of conduct and the discharging of reasonable responsibilities incident to community membership. In requiring these citizens to bear the burden of the general upkeep of the society in which they resided, and to observe the rules for the benefit of all concerned, the state did not offend or violate the spirit or the specifics of the constitution.

The Murdock case in overruling the Opelika decision established the following general principles: First; Under the Federal Constitution, a municipal ordinance requiring the payment of license fees as a condition to the pursult of the activities of colporteurs, is a denial of freedom of speech, press, and religion. Secondly; the activity of the colporteur does not become a commercial enterprise just because he "selis" his articles rather than "donates" them. Thirdly; that the ordinance is nondiscriminatory and applies to peddlers of all merchandise is immaterial. The First Amendment freedoms enjoy a "preferred position." Fourthly; inasmuch as the privilege 
In question is guaranteed by the Federal. Constitution, the question as to whether the state can ask for something in return for what it has provided is irrelevant. And lastly; a state may not suppress the dissemination of ideas by taxation merely because the ideas being propagated are annoying, unpopular, or distasteful.

The case of Martin v. Struthers, supra, in which the Court invalidated a state statute forbidding door-to-door distribution of literature, was decided on the same day as the Murdock case. In addition to these two cases, the Court also handed down the decision of Douglas v. Jeannette ${ }^{130}$ on May 3, 1943. The majorityropinion of these three cases indicate a reasonable consistency on the part of the Court. The arguments were heard by the court during the same period, and the decisions rendered followed a systematic pattern. The division on the bench was identical in the Murdock and Struthers cases, five to four. Of the four dissenting Justices, Reed, Frankfurter, Jackson, and Roberts, Jackson, joined by Frankfurter, declared in the Douglas case that he concurred with the majority not dissented in Murdock and Struthers.

The Douglas case did not differ materially from the Murdock case and was so acknowledged by the Court. Hence, in deciding upon the case, the Court was mindful of the Murdock decision to which it made references freely. The main 
168

difference between the two cases was over the question of appeals process. The Jehovah's Witnesses as per usual were engaged in the sale and distribution of religious literature without payment of a license tax which was required by a Jeannette City ordinance. The Witnesses hoping for a reverse ruling of the opelika decision probably brought all of these cases based upon various legal grounds, simultaneously. It was, in a way, a "collateral" attack in separate courts of the same legal issues.

The Murdock case arose from a series of cases in the City of Jeannette, Pennsylvania. The Douglas case too, involved the same group, engaged in the same activity, violating the same rules, but the appeal was made before a Federal Court under equity, to restrain threatened criminal prosecution by state courts. In short, it was a writ of injunction that the petitioners sought. The United States district court had refused to issue an injunction but had enjoined the state from enforcing the ordinance on the ground that it denied the petitioners rights of freednm of press and religion guaranteed by the Fourteenth Amsndment. The Third United States Circuit Court of Appeals did not deny the jurisdiction of the lower court, but reversed the decision under the authority of the Orelika ruling. Therefore, petitioners appealed and were granted certiorari by the high court. Mr. Chief Justice Stone delivering the majority opinion posed the constitutional problem as embracing two issues: 
169

The questions decisive of the present case are whether the district court has statutory jurisdiction as a federal court to entertain the suit, and whether petitioners have by their pleadings and proof established a cause of action in equity.131

The suit was brought before the court in behalf of all the Jehovah's Witnesses of Pennsylvania and adjoining states who were required to pay a license fee before engaging in their religious pursuits. The Court quickly disposed of the diversity of citizenship question on the ground that some of the petitioners, like the respondents were citizens of Pennsylvania. The petitioners contended that the ordinance denied them freedom of speech, press and religion guaranteed by the First Amendment and made applicable via the Fourteenth.

On the first constitutional question, the Chief Justice said, although there was no proof that the matter in controversy exceeded $\$ 3,000$, under the Civil Rights Act, the district court had jurisdiction to hear and decide the question of the constitutional validity of the ordinance. Under the Act, "any person. . .state or territory" causing injury "shall be liable to the party injured in an action at law, suit in equity, or other proper proceeding for redress."132

Unlike the contention in other license tax cases, the

$$
\begin{aligned}
& 131 \text { Ibid., p. } 159 . \\
& 132 \text { Ibid., p. } 161 .
\end{aligned}
$$


appellants claimed:

that respondents, proceeding under challenged ordinance, by arrest, detention and by criminal prosecutions of petitioners and other Jehovah's witnesses had subjected them to deprivation of their rights of freedom of speech, press and religion secured by the Constitution, and the complaint seeks equitable relief from such deprivation in the future. $13 \overline{3}$

This was quite different from Murdock, Struthers, and other similar cases, in that the petitioners were praying the court for future relief.

Under Anglo Saxon legal procedure, injunctions and stays of action will be granted under equity jurisdiction only if there is demonstrable evidence that unless the action is enjoined, irreparable damage would occur. This is not the same as anticipating evils or crimes. The damage, usually civil in nature, must be irreparable; and the writ can issue only from a court of equity jurisidiction. There was no question whatsoever that the district court in the instant case, had jurisdiction in the controversy, and had the authority to issue a writ of injunction under equity. But "petitioners are entitled to the relief prayed only if they establish a cause of action in equity."134 Stone felt that especially when a petition seeks to invoke the powers of the Court

$$
\begin{aligned}
& { }^{133} \text { Ibid. } \\
& 134 \text { Ibid., p. } 162 \text {. }
\end{aligned}
$$




\section{1}

through an infunction, to interfere with threatened criminal prosecutions in a state court, the motion should be objected to. "It is a familiar rule that courts of equity do not ordinarily restrain criminal prosecutions."IB5 Because the act is alleged to be a violation of constitutional rights, is not a ground for equity relief since the constitutionality of ordinances and statutes can "be determined as readily in criminal cases as in a suit for an injunction."136 In other words, an injunction being a last-resort remedy need not be made available when the relief can be granted through other procedural channels. Stone then laid down a rule of law not novel, but certainly not wanting in clarity and constitutional nicety.

Where the threatened prosecution is by state offices for alleged violationscof a state law, the state courts are the final arbiters of its meaning and application, subject only to review by this court on federal grounds appropriately asserted. Hence the arrest by the federal courts of the processes of criminal law within the states, and the determination of questions of criminal liability under state law by a federal court of equity, are to be supported only on a showing of danger of irreparable infury 'both great and immediate." 137

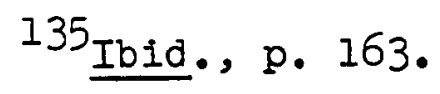

136 Ibid.

137 Ibid., pp. 163-164. cases cited: Spillman Motor Company v. Dodge, 295 U.S. 89 (1935); Beal V. Missourl Pacific RaI1way Corporation., 312 U.S. 45 (1941); Watson v. Buck, 313 U.S. 387 (1941), and Williams v. Milier, 317 U.S. 599 (I942). 
If the case presented any difficuit constitutional problems, in the light of the Chief Justice's lucid statement, the controversy seems not to be a controversy at all. Unfortunately, not all issues can be resolved by simple statements. Actually, the difficulty in the present case was not in establishing a point of law however illusive that may have been. The real difficulty was in determining whether there was enough evidence of a threatened irreparable injury which the court had a right to prevent. This question too, Stone disposed with relative ease.

- . the Court made no finding of threatened irreparable injury to petitioners or others and we cannot say that the declared intention to institute other prosecutions is sufficient to establish irreparable injury in the circumstances of this case. 138

The real importance of the case diminished because of the Murdock decision which struck down the validity of the licensing ordinances. In the first place, stone noted that "an injunction looks to the future,"139 which the federal courts should be careful in appraising. Courts should not envisage in advance all the possible diversity of evils and rule under what conditions freedom of religion, speech or press may or may not be violated. Secondly, in view of the Murdock decision rendered the same day, "we find no ground 
173

for supposing that the intervention of a federal court, in order to secure petitioners' constitutional rights, will be either necessary or appropriate." 140

So saying, the majority in the Douglas case affirmed the judgment of the Circuit Court of Appeals and dismissed the b1ll. What the case involved, it seems, was an attempt by the petitioners to restrain the state from carrying out an act which it did not have the authority to carry out. The case relterated an established rule; the remedy for the curtailment of a threatened criminal prosecution by the state is not a suit in equity for an injunction in a federal court.

Mr. Justice Jackson joined by Mr. Justice Frankfurter, took the opportunity to express his views in the instant case. He concurred with the majority, but his concurrence was really meant to be the dissent he did not record in the Murdock and Struthers cases. It was his feeling that the court was treating the parts rather than the whole. In all three cases the majority did not deal with the issue in its proper setting. To Jackson, only the Douglas case provided a comprehensive story of the elaborate plan of campaign employed by the Jehovah's Witnesses. And the full impact of their campaign upon the community was the important factor to consider in rendering the decisions. Jackson said that the Douglas record made available certain facts which unquestionably would uphold the 
174

right of states to regulate the activities of this persistently bothersome sect. He pointed to the size of the Watchtower Bible and Tract Society, a corporation engaged in a large revenue-bearing enterprise whose accurate records were not available to the Court; the method of operation and the public disturbances the Witnesses caused, and the outward attack against those who would not subscribe to their teachings. Jackson painstakingly explained the activities of the petitioners in all the cases involved and intimated that their aggressive campaign was, in some cases, purposely designed to frustrate the local authorities. They would never take a reasonable "no" for an answer said Jackson, even when the local authorities were acting in good faith and for their benefit. Often they would invade a c1ty "en masse" and under the direction of a "zone servant," converge on the hapless inhabitants disregarding all rules of courtesy and respect. They would also play their phonograph records which were usually attacks on Christianity in general and the Roman Catholic Church in particular. From Judge Rutherford's book, "Religion" Jackson cited numerous passages making special note of the venomous attack on the Catholic Church as the "Harlot." "Such is the activity which it is claimed no public authority can either regulate or tax."14I over the decision rendered in Murdock and Struthers, "I dissent" said Jackson, "a disagreement

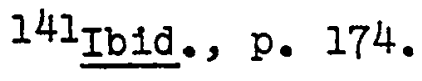


induced in no small part by the facts recited."142 While the Justice presented a well-documented description of the witnesses and their method of campaign, if his dissent were based on these facts alone, it could be concluded that his decision was conditioned primarily by the offensive nature of the Petitioners and their ways -- hardly a constitutional ground for restraint.

Approaching the controversy from a more acceptable -and valid -- constitutional mold, Jackson listed three subjects discussed in Murdock and Struthers, which had the tendency of obscuring the effect of the decisions. The first had to do with the form of ordinances in question. In Murdock, the court held invalid the ordinance because it was not "narrowly drawn," while in Struthers "the ordinance is certainly narrowly drawn. Yet the Court denies the householder the narrow protection it gives." 143 The function of the court according to Jackson, was to decide the constitutionality of the ordinances, in accordance with the construction given them by the state and applied by local autborities, not in "censoring their draftsmanship"144 as the court did in these cases. Secondly; in neither case did the court give clear-cut consideration to particular activities. Instead, the court blended
142 Ibid.

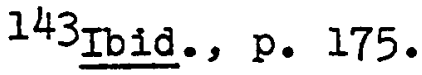
144 Ibid., p. 176. 
176

and confused the issue by including questions which it was not called upon to decide. In the Murdock case the court spoke of restoring liberties of itinerant evangelists to their high, constitutional position without declaring what these privileges were. "Similarly in the Struthers case the Court fails to deal with the behavior of the Witnesses on its own merits."145 The Court actually reached the decision by balancing the ordinance with the right of individual housenolders to receive whomever they pleased. This was a hypothetical situation and the determination of the constitutionality of the ordinance was not served by balancing nebulous rights over reasonable regulatory measures. Jackson agreed that there were hospitable householders who may be glad to receive the literature.
Doubtless there exist fellow spirits who welcome these callers, but the issue here is what are the rights of those who do not and what is the right of the community to protect them in the exercise of their own faith in peace. That issue $\bar{i}$ the real issue -- seems not to be dealt with. 146

Thirdly; although the court admitted in both cases certain evils existed which the state has a right to prevent, it did not identify them, neither did it lay down a workable guide in doing so. In Murdock the Court felt that the requirement of a license fee was quite different from a requirement to give the name, address and other marks of identification.

$$
\begin{aligned}
& 145_{\text {Ibid. }} \\
& 146_{\text {Ibid. }}, \text { p. } 177 .
\end{aligned}
$$


To Jackson there was no difference except for the fee imposed. And he was not willing to say that the fee ranging from $\$ 1.50$ per day to less than a dollar per day for two weeks was unreasonable. "There is not a syllable of evidence that this amount exceeds the cost to the community of policing this activity." 147

As for the suggestion in struthers that the problem should be worked by each community for itself, Jackson said was "somewhat ironical in view of the fate of the ordinances here involved." 148

Iike Frankfurter's argument in the flag salute cases Jackson too was concerned about the ninety and nine. To permit the Witnesses freedom from reasonable restrictions was to assume that all other sects were similarly free from restrictions should they decide to prosecute thelr beliefs with vigor. Then, where does the majority find refuge? Conversely, if a minority can resort to these tactics, what would happen to the minority if a majority decided to impose a similar drive?

A common-sense test as to whether the court has struck a proper balance of these rights is to ask what the effect would be if the right given to these Witnesses should be exercised by all sects and denominations. If each competing sect in the United States went after the householder by the same methods, I should think it intolerable. 149

$$
\begin{aligned}
& 147 \text { Ibid. } \\
& 148 \text { Ibid., p. } 178 . \\
& 149 \text { Ibid., p. } 180 .
\end{aligned}
$$


178

This argument seems to be an anticipation of evils which are quite unlikely to occur -- an argument which both the majority and minority opinions have repeatedly looked upon with disfavor.

Throughout his dissent Justice Jackson seemed to have been especially disturbed by theooffensive nature of the Petitioners' practices. The Jehovah's Witnesses had gone beyond the bounds of proper limits in employing their means. Although the First Amendment assured the broadest tolerable exercise of free speech, press, and religion, "Does what is obscene, or commercial, or abusive, or inciting become less Loffensive] if employed to promote a religious ideology?"I50 he asked. The court in the Chaplinsky case held that the Witnesses may not call a public official a "damned racketeer" or a "damned fascist," because the use of these "fighting words" were beyond the limits of privilege,

how then can the court today hold it a 'high constitutional privilege' to go to homes, including those of devout Catholics on Palm Sunday morning, and thrust upon them literature calling their

church $a$ 'whore' and their faith a 'racket'?151

To Jackson, at best, it was a questionable use of religious freedom to permit the vulgar criticism against another religion, and certainly a misuse of a cherished right to knock on

$$
\begin{aligned}
& \text { 150 Ibid., p. } 179 .
\end{aligned}
$$

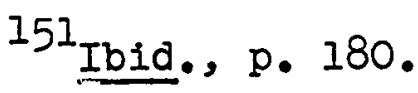


179

someone's door and against his will enter or thrust into his hand articles which may appear to the householder undesirable or completely in opposition to his own religious convictions. The Court, he said made the aggressive method of the petitioners the law of the land by trying the hands of all local authority. He then issued a warning:

This court is forever adding new stories to the temples of constitutional law, and the temples have a way of collapsing when one story too many is added. 152

Although Mr. Justice Jackson's opinion has been recorded as a concurring decision, it was, for all practical purposes, a dissent. Inasmuch as the three cases, Murdock, Struthers and Douglas, were heard at the same time, and Jackson dissented in the first two without a written opinion, he took this occasion to write his dissatisfaction over the majority decisions. He was in favor of the Douglas decision but said nothing about it, instead his implicit rationale was that the Douglas opinion would be consistent only if Murdock and Struthers were vacated. All three cases dealt with one broad question in the opinion of Jackson, and were the decisions in Murdock and Struthers decided according to his reasoning, not only would the Douglas decision be consistent, there would really be no need for it.

A month later, in June of 1943, the court heard and 
disposed of a case involving the witnesses and a violation of a District of Columbia license tax ordinance. 153 The petitioners were convicted of selling religious literature on the streets of District of Columbia without first procuring a license and paying the tax required by a District of Columbia ordinance. The petitioners were charged and convicted in a police court. Relying upon the Opelika decision the Court of Appeals of the District of Columbia affirmed the lower court, judgment holding that the statute was applicable as well as constitutional. on a writ of certiorar1 the Supreme court received the case and delivered a per curiam decision. In view of the opelika and Murdock decisions the Court vacated the lower court judgment and remanded the case to the court of Appeals to study and examine its ruling on the construction and validity of the District of Columbia ordinance. Mr. Justice Rutledge took no part in the case.

It is very frequently true that when the supreme court renders a decision with far-reaching implications, other cases which amount to no more than "test cases" spring up for review. This is especially true when state action of some kind is prohibited. The high court's decision, as would be expected cannot cover all of the legal "loopholes," and only as judiclal construction is provided from time to time, can a controversial law be adequately administered. The most prominent examples of this practice are the decisions affecting Negroes, 
181

and civil rights cases in general. To be sure, the Opelika Murdock - Busey rule did not cover satisfactorily all cases arising under similar conditions. Taking note of the Murdock rule which seemed to apply more specifically to itinerant ministers, the town of McCormick, South Carolina charged and convicted a local minister on the basis that the previous decisions of the court were not applicable against resident ministers. $154 \mathrm{Mr}$. Justice Douglas' majority opinion seemed to express an irritation which was not altogether inappropriate, for he said:

\begin{abstract}
We referred to the itinerant nature of the activity in the Murdock case merely in emphasis of the prohibitive character of the license tax as so applied. Its unconstitutionality was not dependent on that circumstance. 155
\end{abstract}

The case arose after a minister of the town of Mccormick was convicted for "selling" religious literature without taking out a license and paying the fee as required by a municipal ordinance. The ordinance required of all agents selling books to pay a license fee of $\$ 1.00$ per day, or $\$ 15.00$ per year. The license was required of all persons carrying on the activity as their business, occupation, or profession. The appellant was convicted by a jury in the Mayor's Court, and the judgment was affirmed by the Circuit court of General

$$
\begin{aligned}
& \text { 154 Follett v. Town of McCormick, } 321 \text { U.S. } 573 \text { (1944). } \\
& \text { 155 Ibid., p. } 577 \text {. }
\end{aligned}
$$


182

Sessions for McCormick County, and then by the Supreme Court of South Carolina. The petitioner appealed the case to the United States Supreme court on the ground that the ordinance violated his freedom of worship as guaranteed by the First Amendment made applicable to states by the Fourteenth. The American Civil Liberties Union again filed a brief of amicus curlae urging reversal of the lower court judgment.

The state courts recognized and acknowledged the opelika and Murdock decisions, but distinguished them from the instant case. Their contention was twofold: (1) that the appellant was not an itinerant evangelist but a local resident whose canvassing took place within his own residential area; (2) that the appellant earned his living by "selling" books; thereIore, he was not a colporteur, but a salesman by occupation. The respondent added that the "license was required for the selling of books, not for the spreading of religion."156 Furthermore, argued the respondent, in this case, the nature of the activity engaged in was more commercial than religlous a fact which made the Murdock decision inapplicable.

To the majority of the Supreme court, the case appeared to be some sost of a "frustration device." Douglas pointed out that even the state court willingly admitted the material offered for "sale" were "religlous books," and it concluded "without difficulty that its publication and distribution 
183

come within the words, 'exercise of religion,' as they are used in the Constitution."157 The case therefore, was quite different "from that of a merchant who sells books at a stand or on the road." 158

On the question of religious vis a vis commercial activity, Douglas pointed out that the Murdock decision merely indicated that "religious' activity and 'purely commercial' activity would at times be 'vital' in determining the constitutionality of flat license taxes such as these."l59 It did not rule, in any way, that occupations such as pursued by ministers of the gospel because they offered books for "sale," were more commercial than religious.

The question is therefore a narrow one. It is whether a flat license tax as applied to one who earns his livelihood as an evangelist or preacher in his home town is constitutional. 160

It appeared clear to Douglas that preachers of more orthodox faiths need not be engaged in commercial undertakings to make a living. And eccording to the Constitution, "Freedom of religion is not merely reserved for those with a long purse."16I

$$
\begin{aligned}
& 157_{\text {Ibid. }} \text { p. } 576 . \\
& 158 \text { Ibid. } \\
& 159_{\text {Ibid. }} \\
& 160 \text { Ibid. } \\
& 161_{\text {Ibid. }}
\end{aligned}
$$


184

The Constitution did not differentiate the needy from the affluent, they can all "avall themselves of the constitutional privilege of a 'free exercise' of their religion. . "162 As a matter of constitutional consistency;

-. If this license tax would be invalid as applied to one who preaches the Gospel from the pulpit, the judgment below must be reversed. For we fail to see how such a tax loses its constitutional infirmity when exacted from those who confine themselves to their own village or town and street. 163

Douglas pointed out that this did not mean that religious undertakings must be subsidized. Neither the preachers nor the parishioners were free from the financlal burdens of government including taxes on income or property. But this subjection to general taxation was not the same as subjecting them to a license tax requirement the prohibition of which was intended by the First Amendment.

Mr. Justice Reed, who wrote the majority opinion in Opelika and registered a lengthy dissent in Murdock, concurred with the majority in the instant case on the ground that there was no difference between an itinerant evangelist and a local minister. It made no difference either that one may be engaged in part time activity while the other devoted all of his time.

162Ib1d., p. 577. To Douglas the flat license tax on a constitutional privilege was as odious as the early "taxes on knowledge" which the framers of the constitution attempted to outlaw. Grosjean v. American Press Co., supra. 163 Ibid. 
185

Reed noted that his decision over the previous cases did not change, but if the Murdock rule was to be applied, the constitutionality of which had already been established, then it should be applied to resident preachers as well as to itinerant evangelists.

The dissenting opinion of Justices Roberts, Frankfurter, and Jackson though brief, made it clear that their view of the case was markedly different. ". . the implications of the present decision," they said, "are starting." 164 They observed at the outset that first of all, the law was not discriminatory. It was a tax on occupation, not a singling out persons or certain occupations. There was no other purpose than to raise revenue from all who enjoy the service and protection of government. Secondly, the ordinance laid no onerous burdenion certain occupations, or persons pursuing them. It was not like the tax in question in the Grosjean case in which the measure discouraged and suppressed the pursuit of a particular calling. If civil liberty were to be obtained, there must be a reasonable monetary exaction from all who enjoy the benefits contained and provided therein.

The petitioner Follett, according to the dissenting opinion was being required to pay for that which all others similarly situated were required to pay -- an excise for street venging. Using this reasoning, the dissenters presented their

${ }^{164}$ Ibid., p. 582. 
most vigorous attack.

Follett asks exemption because street vending is, for him, also part of his religion. As a result Follett will enjoy a subsidy for his religion. He will use the contribution for the cost of government which everyone else will have to pay.165

The instant case, on this basis, according to the dissent, appeared very different from Murdock. In not differentiating between the itinerant evangelist and the full-time preacher, the court permitted the intrusion of certain practices which were not within the permissive scope of the First Amendment.

In effect the decision grants not free exercise of religion, in the sense that such exercise shall not be hindered or" limited, but, on the other hand, requires that the exercise of religion be subsidized. Trinity Church owning great property in New York City, devotes the income to religious ends. Must it, therefore, be exempt from paying its fair share of the cost of government's protection of its property?166

Saying "we cannot ignore that this decision involves," the dissenters were fearful of the extension of this exemption into the area of speech and press. If the First Amendment guaranteed immunity from taxation for religious activity, then the Amendment must guarantee equal immunity to the exercise of speech and press alike. If therefore, taxes cannot be exacted from Jehovah's Witnesses because they are primarily engaged in religious pursuits, "they can no more be enforced against

165 Ibid., pp. 580-581.

166 Ibid., p. 581 . 
publishers or vendors of books, whether dealing with religion or other matters of information."167 Under such a daring doctrine, those who administer to the sick, nurse the disabled, work for the betterment of social and economic conditions, or engage in a myriad of other services, are immune from taxations if they would but claim thelr pursuit to be an exercise of religious beliefs. Such a claim no matter how earnest or honorable, did not entitle them to be free of the cost of government which actually protects their clains to freedom.

Mr. Justice Murphy, concurring with the majority sought to deal with the dissenting opinion rather summarily. His opinion in all probability would not have been recorded, were it not for the dissenting opinion which he thought to be quite unrealistic. The contention that the majority opinion "subsidized" religion, Murphy said, was "merely a harsh way of saying that to prohibit the taxation of religious activities is to give substance to the constitutional right of religious freedom." 168 To the reference that Trinity Church and taxation on its property investment would be exempted by the majority reasoning, Murphy aaswered, "I am neither disturbed nor impressed by these allegations." 169 The Court was not deciding on income arising out of extensive property holdings and

$$
\begin{aligned}
& 167 \text { Ibid., p. } 582 . \\
& 168_{\text {Ibid., }} \text { p. } 579 . \\
& 169_{\text {Ibid. }} .
\end{aligned}
$$


businesses related thereto.

There is an obvious difference between taxing commercial property and investments undertaken for profit, whatever use is made of the income, and laying a tax directly on an activity that is essentially religious in purpose and character or on an exercise of the privilege of free speech and free publications. 170

To Murphy the distinctions were apparent, while to the minority there were no distinctions, only layers of overlapping premises. Murphy felt that to afford immunity from taxation to religious pursuits was not to provide other similar practices with a horrendous panoply of safeguards from reasonable financial exactions by the government. What Justice Murphy was proposing was the same principle evolved by the court in all of these licensing ordinance cases, that the taxing and licensing power in the hands of unscrupulous and bigoted men would be a weapon that might easily be used to restrict and suppress freedom. Thus the power must be confined to appropriate bounds. To keep the power within the confines of proper control, Court decisions must not be bound to abstract arguments and their logical conclusions. Because religious practices are non-taxable under certain conditions, it does not follow that exercises of speech and press under conditions which appear to be similar are likewise tax exempt. In a sense, the majority was proposing a flexibility rule -- if necessary -- whereas 
189

the minority felt that flexibility would only add to the confusion and complexity it helped to create.

The judgments rendered in these cases indicate a willingness on the part of the court to grant religion a favorable position regarding license fees and taxation. It was of no consequence that religious literature was actually "peddled;" under the First Amendment guarantee of religious freedom, immunity from pedding taxes was constitutionally protected. The power of municpal and state agencies to impose license taxes on peddlers was thus restricted to those of a non-religious nature. 


\section{CHAPTER VII \\ "THOU SHALT NOT GIVE ALIEGIANCE"}

If the Jehovah's Witnesses are remembered for anything at all in the American climate of thought, they are remembered best -- in most cases with opprobrium -- for their stubborn refusal to salute the flag. The Supreme court cases Involving this controversy are few in number, but the paucity of cases concerning this issue is not in any way a reflection of the amount of litigation that followed. Not only was the battle cloaked in legality, the social pressures reached such proportions that to describe the persecution inclicted upon this sect in a period of a few weeks in 1940, after the first flag salute case, ${ }^{l}$ would entall several volumes each of which would be at least equal to this study. Newspapers and periodicals abounded da1ly with the record of mistreatment dealt by the public to this band of crusaders whose sin consisted of activity provoked by fanatic dedication. The unpopularity of their views under normal conditions evoked enough unfavorable response, but time too, seemed to be at odds with the witnesses. For one thing, in 1940, war was raging in Europe. "The decision came at a time of exceptional emotion when the world staggered under the shock of the impending fall of France, with the vast implication of that event."2 The misfortune in timing

IMinersville v. Gobitis, 310 U.S. 586 (1940).

The Bill of Rights Review I (Summer 194I), p. 267. 
191

was espectally telling in the feeling of uneasiness over national security which was engulfing the country at the time. All these, plus other factors, made patribtism over-charged with emotionalism beyond reasonable proportions.

The American public, it has been said, is slow to anger and not easily overcome by uncontrollabie wrath. The Jehovah's Witnesses, by their uncompromising actions disproved this rule. On the other side of the coin, the argument takes the position that the rule is not disturbed because the maltreatment imposed upon this wayward sect was far from the degree to which the public was incensed. However distant or whatever depth these arguments may reach, one thing remains clear; the Jehovah's Witnesses;

For being generally offensive have been getting their heads cracked, their meetings broken up, their meeting houses pillaged and themselves thrown in jail. . - For refusing to salute the flag they have been assaulted by rampant patriots in scores of communities all the way from Del Rio, Texas, to Kennebunk, Maine.3

It is difficult to envision such undertakings on a wide scale in politically healthy and religiously free America. History seems to indicate that America has not been free of religious intolerance, but in most cases physical punishments were inflicted on a small scale in isolated areas.

The Flag Salute cases have been the subject of numerous

${ }^{3}$ Saturday Evening Post, Sept. 14, 1940, p. 18. 
articles and books. 4 All books on constitutional law deal with them to some degree. To be sure, the Flag Salute cases established important constitutional principles in the area of civil liberties; but the core of the issue centers on sociology more than public law. Most of the studies in this area appropriately deal with the social relations aspect rather than the legal element. It is true that the supreme court itself was locked in a legal battle, but many writers point out that the Justices themselves were controlled greatly by preconceived notions reeking with pressures imposed by their environment. The Flag Salute cases differ from most other Jehovah's Witnesses case in a very important respect; compulsion by an authority upon persons to perform an act which they did not entertain and which violated their religious convictions. Other than the cases dealing with conscientious objectors, this is the outstanding distinction from all other Jehovah's Witnesses

4 The best work to date on the Flag Salute cases is David R. Manwaring, Render Unto Caesar (Chicago: Univ. of Chicago Press, 1962), 321 p p. This excellent study with copious notes and detailed accounts of the activities in all the states where the controversy has been most notable, was published too late to have any substantial effect on this chapter. By the time Professor Manwaring's book appeared, this chapter was fairly complete. It is gratifying for this writer to note that there is much overlapping between the two in terms of research and general evaluation. There is one significant difference however. Mr. Manwaring has devoted a great deal of space to state activities, while this chapter is confined to a study of the Supreme court cases and selectively relevant public reaction. The numerous articles dealing with this issue, because of their voluminous nature do not all appear in the present study. The articles which do appear however, have been carefully selected for pertinency and interest. 
193

cases. Another difference between these and other cases is that wherever similarities occur, they are magnified and intensified in the flag salute cases.

The flag, as a symbol of national unity, 5 has been institutionalized into man's thinking and is perhaps as old as civilization. In modern times it has come to mean the embodiment of the whole national culture and all of its vast network which give the nation its value and distinction. Very few symbols, if any, are revered and given as much deference as a nation's flag. For the flag, and what it represents, people have willingly killed and gladly died. The mysteries of life itself have a strange affinity with the unexplainable attachment of man to a banner usually made of nothing more than a piece of cloth. So sacred is the flag that it is used for the most solemn occasions; it is never permitted to touch the ground, it is always placed on the right side, it is a badge of honor for the deceased, and in some cases it is not permited to fly on a rainy day. A replica of it certainly may not be used on commercial advertising posters. 6 In Justice Frankfurter's words, because "we live by symbols," the flag

5 See Halter v. Nebraska, 205 U.S. 34 (1907). For a history of the flag there are many good works. Cf. James Alfred Moss, The Flag of Our United States (Chicago: Rand McNally and C.o., 1938), $54 \mathrm{pp}$; and Milo Milton Quaife, The Flag of the United States (New York: Grosset and Dunlap, 1942), 210 pp. For a brief history in relation to the flag salute cases, see "The Flag Salute," Journal of National Education Association XXXII (Dec., 1943), pp. 265-266. 
194

is a representation of national security, a value which is inferior to none in the "hierarchy of legal values."7

The case of Minersville v. Gobitis, came to the Supreme Court on a writ of certiorari to review the affirmance of a decree by the District Court and the Circuit Court of Appeals, enjoining the School Board of Minersville, Pennsylvania from enforcing a compulsory flag salute resolution. The resolution of the School Board was lawfully adopted and the expulsion of students who refused to comply was within the power and authority of the Board. The expulsion of students violated neither the Constitution of the United States,nor thelaws of Pennsylvania. 8

Lillian Gobitis, aged twelve, and her brother William, aged ten, were expelled from school for refusing to participate in a daily flag salute exercise required of all pupils and teachers of Minersville Public schools. The members of the Gobitis family were members of the Jehovah's Witnesses who in accepting God's Word as the supreme authority in all their actions felt that to salute the flag would be to disobey God's

\section{Minersville v. Gobitis, p. 594.}

8In declaring that the expulsion action did not violate the Federal Constitution, the respondents cited Hamilton v. Board of Regents, Reynolds v. United States, supra, Selective Draf't Law cases, 245 U.S 366 (Ig18), Un1ted States v. MacIntosh, 283 U.S. 605 (1931), and other older cases. To support the contention that the action did not violate state law the respondents cited Pennsylvania cases. See Ibid. 
commands. 9 In accordance with the resolution, the Gobitis children were expelled from public school and their parents put them into a private school. Because of the heavy financlal burden of a private school, the father, on behalf of his children brought the suit before the courts seeking to enjoin the school authorities from exacting the practice of saluting the flag as a condition for attendance in public school. The District Court Judge gave relief after a thoughtful opinion, but inasmuch as the opinion ran counter to previous per curiam decisions 10 of the supreme court, certiorari was granted.

Briefs of amici curiae were filed by the committee on the Bill of Rights, and the American Civil Liberties Unton, Il urging affirmation of the lower court decree.

The contentions of the petitioners hinged mainly on the reasoning that saluting the flag was not "by any stretch of

These commands are found in the old Testament of the Bible in the book of Exodus, Chapter 20. In part, the Scriptures say, "Thou shalt have no other gods before me." verse 3. "Thou shalt not make unto thee any graven image, or any likeness of any thing that is in heaven above, or that is in the earth beneath, or that is in the water under the earth." verse 4. "Thou shalt not bow down thyself to them, nor serve them." verse 5 .

10These were the cases cited earlier by the respondents in contending that their action did not violate the Federal constitution.

1IThe Committee on the Bill of Rights and the American Civil Iiberties Union played a significant role in informing the public through their publications, Bill of Rights Review and the American Civil Liberties Union reports respectiveiy. There is no way of evaluating to what extent these groups were able to influence the court if at all. 


\section{6}

the imagination, a form of worship."12 The salute had no religious implications whatsoever, and it was the petitioners' view that the commandments of Jehovah sanctioned the salute rather than prohibited it. Teaching youngsters to be loyal to their state and country was a patriotic act which did not violate sacred commands. Furthermore:

The act of saluting the flag does not prevent a pupil, no matter what his religious beliefs may be from acknowledging the spiritual sovereignty of almighty God by rendering to God the things which are God's. 13

The respondents' arguments were based mainly on the contention that their religious freedom guaranteed from state infringement by the Fourteenth Amendment was violated. The determination of what a person shall or shall not believe was left to the individual himself to decide, and not any outside authority. The saluting of the flag, the respondents claimed, was a form of idolatry prohibited by their religious beliefs. The expulsion of children for refusing to violate their conscience was not only wrong, but constituted cruel and unusual punishment. In answering the petitioners' clalm that the flag salute was a method of instilling in the children patriotism and loyalty to the country, the respondents' engaged in a bit of burlesque.

12Minersville School District v. Gobitis, p. 588 . 13 Ibid. 


\section{7}

Why limit that compulsory rule to teachers and pupils of the public schools? Why not require that same ceremony in all the schools? Why not apply the same rule to all officials of the nation and state, from the President and members of congress down to the very least and humblest citizen?17

Mr. Justice Frankfurter delivered the opinicn for the majority against the lone dissent of Harlan Fiske Stone. Both men have been immortalized by their opinions either by being apotheosized or ridiculed.

In a broad sense, Justice Frankfurter saw this case bo differentiy from the others.

A grave responsibility confronts this Court whenever in course of litigation it must reconcile the conflicting claims of liberty and authority. But when the liberty invoked is liberty of conscience, and the authority is authority to safeguard the nation's fellowship, judicial conscience is put to its severest test. Of such a nature is the present controversy. 15

The language is general enough to apply to all cases affecting the Jehovah's Witnesses, for they all prevailed upon the court to reconcile the conflict between liberty and authority. What the court, in this instance was asked to decide, admitted the Justice, was whether the requirement of a child to participate In a flag salute ceremony denied him liberty granted by the Fourteenth Amendment. Narrowing the question further;

The precise issue, then, for us to decide is whether

$$
\begin{aligned}
& 14 \text { Ibid., p. } 590 . \\
& \text { 15Ibid., p. } 591 .
\end{aligned}
$$


198

the legislatures: of the various states and the authorities in a thousand counties and school districts of this country are barred from determining the appropriateness of various means to evoke that unifying sentiment without which there can ultimately be no liberties, civil or religious. 16

The crux of the issue, at least for the majority, was the extent to which legislative judgment may be permitted. In this case, however harsh the requirement may appear to some, if the "end is legitimate," I7 and the effective means to attain these ends are not yet properly determined or authenticated, the authority to evaluate and administer these means should not be put "beyond the pale of legislative power."18 To do so, would be to mock reason and deny "our whole history to find in the allowance of a requirement to salute our flag on fitting occasions the seeds of sanction for obeisance to a leader."19 The training of children for patrintic impulses is an educational system not subject to the court's independent judgment, according to the Justice's reasoning, "To choose among competing considerations in the subtle process of securing eflegtive loyalty to the traditional ideals of democracy. - .would in effect make us the school board of the

${ }^{16}$ Ibid., p. 597.

17The phrase was first employed by the eminent John Marshall in McCulloch v. Maryland, 4 wheaton 316 (1819). 18 Minersville School District v. Gobitis, p. 598. 19 Ibid., p. 598. 
country."20

To Mr. Justice Frankfurter the issue at hand involved the existence of an organized political society. "The ultimate foundation of a free society is the binding tie of cohesive sentiment,"21 and the continuity of an ordered civilization is dependent upon the preservation of this cohesive feature. Iincoln's dilemma -- "must a government of necessity be too STRONG for the liberties of its people, or too WEAK to maintain its own existence?"22 -- was quoted by Frankfurter as being a problem which could not be solved by "mere textual reading or logical talisman."23 It is here that all the sentiment fostered by mind and spirit, the traditions of a people, and the continuity of a treasured common life which constitutes a civilization, become the determining factors in attempting to solve the dilemma. And the personal notions of judges cannot make a wise adjustment of the issue.

In dealing with what Frankfurter called the "formative period in the development of citizenship, "24 the state was at a disadvantage over the authority of the parents over their children as long as parents were unmolested in their right

$$
\begin{aligned}
& { }^{20} \text { Ibid., p. } 598 . \\
& 2{ }_{\text {Ibid., p. } 596 .} \\
& 22 \text { Ibid. } \\
& 23 \text { Ibid. } \\
& 24 \text { Ibid., p. } 598 .
\end{aligned}
$$


200

to persuade their children to believe contrary to the ends which the state was trying to achieve.

Except where the transgression of constitutional liberty is too plain for argument, personal freedom is best maintalned -- so long as the remedial channels of the democratic process remain open and unobstructed -- when it is ingrained in a people's habits and not enforced against popular policy by the coercion of adjudicated law. 25

There was no question over the authority of a state to compel the participation in a flag salute ceremony by those whose conscientious scruples were not adverse to the practice, hence, said Frankfurter in his most convincing language;
F. 7 or us to insist that, though the ceremony may be required, exceptional immunity must be given to dissidents, is to maintain that there is no basis for a legislative judgment that such an exemption might introduce elements of difficulty into the school discipline, might cast doubts in the minds of the other children which would themselves weaken the ef- fect of the exercise. 26

This would mean that the road would be open for subversion. If the effect of the exercise would be weakened to the extent that other children would be affected, then the end which the state has a right to pursue would be greatly endangered if:not completely nullified. Without a feeling of loyalty to the country, there would be no desire to preserve the values and

${ }^{25}$ Ib1d., p. 599.

26Ibid. 
201

traditions of the country in which one resides. Taken to this end, by destroying the nature of freedom and democratic institutions of this country, the very basis affording the respondents their right to petition the Courts for relief over unfavorable practices would be abolished. The court did not take its argument to this logical conclusion, but all the implications for such a conclusion were present in the case. What the majority did, was to make a strong case for legislative presumption. In his usual eloquent fashion Frankfurter brought his opinion to a close by noting:

Judicial review, itself a Iimitation on popular government, is a fundamental part of our constitutional scheme. But to the legislature no less to the Courts is committed the guardianship of deeplycherished liberties. . . "To fight out the wise use of legislative authority in the forum of public pinion and before legislative assemblies rather inan to transfer such a contest to the judicial arena, serves to vindicate the self-confidence of a free people.27

The reaction to the Gobitis decision was immediate. The attack on Just1ce Frankfurter, although not physical was no less severe than the oppression meted out to the Jehovah's Witnesses. "In 1940 there were more than three hundred cases of mob violence against them."28 But these were separate

$$
27 \text { Ibid., p. } 600 \text {. }
$$

${ }^{28}$ Stokes, Church and state in the United States, p. 545. The best sources for the record of violence against the Witnesses are the newspapers and periodicals. Because of the large amount of such records, it is impossible, in this study to Iist them all. In essence, they all describe the persecution of the Witnesses by the general public. 
202

attacks against many different groups. Frankfurter for his

part in the case became the subject of derision and ridicule

from the lowliest to the learned. He was accused of "abnegating" the authority of the supreme court to exercise judgment;

\begin{abstract}
II/t is, in essence, a rather plain invitation to the majority to work its will on the minority in matters of conscience so long as the majority of the court can say that the imposed will is that of the educational fraternity and is exercised to strengthen the binding tie of cohesive sentiment' which Justice Frankfurter says is the 'ultimate foundation of a free society. 129
\end{abstract}

The invectives against the Justice were legion. Perhaps the most caustic -- certainly the most unwelcome -- issued from a noted student of constitutional law.

But even more distasteful than the ruling itself is Justice Frankfurter's smug assumption that the Court is the happy possessor of a patent formula which enables it in cases like this to dispense with exercising its own judgment. 30

In plain terms, Professor Corwin was accusing the Justice of

${ }^{29}$ Herbert W. Clark, "Reasoning of Mr. Justice Frankfurter in Interpreting the Constitution, "The State Bar Journal of the State Bar of California XVI No. I2 (Dec. I94I), p. 372.

30 Edward S. Corwin, Constitutional Revolution Limited (California: Clairmont Colleges, 1941), p. 112. Professor Cushman's diatribe is no less trenchant. "AII of the eloquence by which the majority extol the ceremony of flag saluting as a free expression of patriotism turns sour when used to describe the brutal compulsion which requires a sensitive and conscientious child to stultify himself in public." Robert E. Cushman, "Constitutional Law - 1939-40, APSR XXV, No. 2 (April, 1941), p. 271 . 
203

abandoning "a ready sense of need for alteration. . the most precious talent required of the supreme court."3I There were some who felt that Frankfurter erred in thinking that proper respect for the flag can be taught by the methods upheld. "It seems probable that a reversal of that ruling. would profoundly enhance respect for the flag. "32 There is no way to determine precisely what forces make for certain behaviour or belief. "It is hard to know what the influences are that shape up one's philosophy of life. Some are in the genes of the bloodstream. Some go back to happenings too distant to remember. Some come from raw experience."33 It was primarily on this basis Justice Stone felt there were other and better ways to teach loyalty and patriotism. 34

The lonely voice in the widderness of Justice Stone in the instant case was not in opposition to legislative initiative in matters of education. Neither was the Justice opposed to suppression of religious practices when they endangered the morals, safety, health, or good order of the public. What the government was attempting to do in this case stone felt,

31 Felix Frankfurter, Law and Politics: Occasional Papers of Felix Frankfurter 1913-1938, ed. Archibald Maclelsh, añ S.F. PrIchard, Jr. (New York: Harcourt Brace and Co., 1939), p. 124 .

32 Rotnem, A.P.S.R., XXXVI p. 1063.

33Douglas, An Almanac of Liberty, p. 352.

34 Minersville v. Gobitis, see dissenting opinion. 
204

was to coerce a child into doing something which his conscience could grant no approval. And the importance of the matter lay in the fact that the end result to be realized from the granting of the right to refuse participation in a flag salute ceremony, out-balanced the good to be derived from forced participation. Th1s was the proper "accommodation" between constitutional guarantees and the powers of government.

The contention that the Court should not pass judgment on the requirements set up by the school board over means of instruction for the purpose of instilling in the minds of children the feeling of loyalty and patriotism, Stone said, was "a long step. . . which I am unable to take. . "35

The guarantees of civil liberty are but guarantees of freedom of the human mind and spirit and of reasonable freedom and opportunity to express them. . . The very essence of the liberty which they guaranty is the freedom of the individual from compulsion as to what he shall think and what he shall say, at least where the compulsion is to bear false witness to his religion. 36

The distinction between the majority opinion of Frankfurter and the dissent by Stone lay in the reliance put upon

35 Ibid., p. 602 。

36 Ibid., p. 604. Stone's position was supported by the Christian Century, "America's foremost liberal journal of reIigion, and crystalized in one sentence: 'It is bitterly ironical that a free government should inflict a penalty for refusal to salute a symbol of freedom." Quoted in Hollis Barber, "Religious Liberty V. Police Power: Jehovah's Witnesses," A.P.S.R., XLI (April, 1947), p. 232. This article, similar to Rotnem's article supra, dealt briefly with all the Jehovah's Witnesses cases brought before the supreme court up to the time of writing. 
205

First Amendment guarantees. Frankfurter did not look upon the case as strictly a "religious freedom" issue, while to Stone the heart of the case centered exactly on that issue. Thus the former applied the "secular regulation" rule and the latter limited the rule to cases involving more important legislative matters. To Stone the School Board's action was unwarranted in view of the more important freedom being infringed by the act.

I am not prepared to say that the right of this small and helpless minority, including children having a strong religious conviction, whether they understand its nature or not, to refrain from an expression obnoxious to their religion, is to be overborne by the interest of the state in maintaining discipline in the schools. 37

National unity may be promoted by expressions of loyalty, voluntarily given, but it is quite another matter, thought stone, to compel this expression against the will of the children and their parents, on the assumption that it plays "so important a part in our national unity as to leave school boards free to exact it." 38

According to the Committee on the Bill of Rights which filed a brief of amicus curiae, the crux of the matter related to method.

Shall the praiseworthy object be sought by means

37 Ibid., p. 606.

${ }^{38}$ Ibid. 
206

of patriotic teaching, voluntary ceremonies and

the like that have served us well for five generations? Or shall we resort to the coercion of young children even to the extent of overriding their religious scruples?39

Although some felt that stone was greatly influenced by this and the brief of the American Civil Liberties Union which was also filed as amicus curiae, it seems rather unlikely. It is true however, stone was emotional and somewhat moved by the case, and was "worked-up" when he read his own brief. 40 The Justice went so far as to write a personal note to Frankfurter. "I am truly sorry not to go along with you, this case is one of the relative weight of imponderables and I cannot overcome the feeling that the constitution tips the scales in favor of religion."4I Not only was the whole judicial philosophy akin to the theory of "balance," Stone's words themselves savor strongly of the social adjustment over which he divided from Franifurter and company.

Mr. Justice Stone's argument seems to us conclusive and need no gloss by us or anyone else. He recognized the fact that civil rights are not

39"The Flag Salute Cases," The Bill of Rights Review, I (Summer 1940), p. 9 .

40 Alpheus T. Nason. Harlan Fiske Stone: Pillar of the Law (New York: Viking Press, 1956), p. 528.

4l Handwritten note from Justice stone to Justice Frankfurter. Quoted in Alpheus T. Mason, The Supreme Court From Taft to Warren (Baton Rouge: Louisiana State Univ. Press, 1958), D. 139. 
207

absolute, that government may infringe upon them to ensure its own survival and presumably to protect public morals, safety, health and order. But this right in turn is not absolute; the question is one Of ADJUSTMENT BETWEEN THE POWER OF GOVERNMENT AND THE CONSTITUTIONAL RIGHTS OF THE CITIZEN. 42

In a politically free society, the tendency on the part of the public in responding to the actions of its officials is to heap scorn in greater proportion than encomiums. Hence, the Jibes directed at Frankfurter were much greater in number and weight than those offered Stone. Unfortunately, for the Courts at least, those who agreed with the court said very littie; those who disagreed, made known their dissatisfaction. It would be safe to assume that in most cases, the attack against Frankfurter resulted from a misunderstanding of his reasoning. There was no misunderstanding of the decision, but many thougint the Justice put national unity above freedom of religion. Actually, what Frankfurter did was to apply the "secular regulation" and excluded the case from First Amendment considerations. To him, the core of the contention was not religlous. Perhaps the following is a more deserving appraisal of the Justice; certainly a more sober one.

Both men Frrankfurter and Stone/ agreed that constitutional government does mean limitations on power. For Justice Frankfurter it means something more than this, however. It means respect

42 "Frankfurter and Stone," New Republic, CII (June 24, 1940), p. 843. Italics supplied. 
208

for common laws applicable to all without discrimination and at least some active identification with these symbols that transmit faith in what is commonly called the democratic code. While there are certainly dangers inherent in any restriction upon the minority by the majority, some restrictions have to be placed at times to keep constitutional government going at all, however much we may dislike the fact. 43

To Frankfurter, there were instances when the will of the minority would work a clear detriment to the majority and society in general. This occasion was one of them.

We are so concerned with protecting the minority from the majority that at times we fail to realize that there is a reverse side to this proposition, namely, minority action can have a deleterious effect upon prevalent values. Who then becomes the protector of the majority? 44

The Gobitis case not unlike the license tax cases, evoked strong reaction on the part of those who disagreed with the majority. "No decision in recent years in the field of civ1l liberty has aroused so much informed discussion; and it is interesting to note that the critical comment has been largely adverse to the soundness of the decision." 45 This was true of course in the attitude toward the court. The attitude of the public against the Jehovah's Witnesses was translated into

43Helen Shirley Thomas, Felix Frankfurter, Scholar on the Bench (Baltimore: John Hopkins Press, 1960), p. 51.

${ }^{44}$ Ibid., pp. 51-52.

45Bill of Rights Review, I p. 268. 
209

physical activity by those who favored the decision. The Court's decision therefore provided the needed justification for those who opposed the Witnesses and their ways to carry out their brand of persecution. The division on the bench, the exacerbated calumny directed against Justice Frankfurter and the majority of the court, and the controversy among students and followers of law, were charged with enough emotionnalism and animosity to blow the issue completely beyond reasonable limits. But the most frightful and unjustifiable result of all was the harsh physical treatment accorded the Jehovah:s Witnesses.

The indignant reaction of the public against members of a sect who would dare to refuse to salute the flag was abrupt as it was widespread.

In Mooresville Indiana, "a mob of three hundred men beseiged a meeting of fifty witnesses, shouting 'salute the flag or you won't leave the hall.' The mob blocked the exit until morning when police rescued the terrified witnesses." 46 The zeal with which the outraged public attacked the Jehovah's Witnesses was matched in some cases by the zeal of the Witnesses themselves in their refusal to conform. "Two coal miners, described in the press reports as 'religious zealots,' quit their jobs rather than perform a compulsory salute to the flag." 47

\footnotetext{
46 Jerome Beatty, "Peddlers of Paradise," American Magazine (Nov., 1940), p. 53.

${ }^{47}$ Christian Century LVII, No. 25 (June 19, 1940), p. 792.
} 
210

The ircidents continued. In Kennebunk Maine, "more than two thousand men set fire to the Witnesses' Kingdom Hall, dragged members from their beds, and beat them in an effort to teach them patrlotism."48 In one instance, a member was lured from his home and castrated. 49 The violence took all forms and was likely to occur anywhere there were witnesses and a crowd. The outbursts continued to increase in number and intensity.

In Litchfield, Illinois, one recent Sunday, one hundred Witnesses appeared in twenty-one automobiles, preaching their propaganda against flagsaluting. A mob wrecked twelve of the automobiles and beat up a number of Witnesses, while police and other citizens herded sixty-two men and women to prison for protection. 50

This incident took place on June 16, less than two weeks after the Gobit1s decision was rendered. During that same week:

In Rockville, Maryland, a handful of men carrying an American flag, broke into a Jehovah's Witnesses meeting. When twenty-five Witnesses refused to salute the flag, the place was promptly wrecked and the Witnesses ordered to leave town. 51

The gravity of the mounting hysteria did not pass unnoticed by governmental officlaldom. So great and serious was the storm of indignation against the Witnesses, the Solicitor

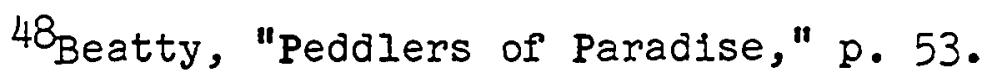

49 $\mathrm{KIngdom}$ News, October, 1940. See Manwaring, Render Unto Caesar, p. 165 .

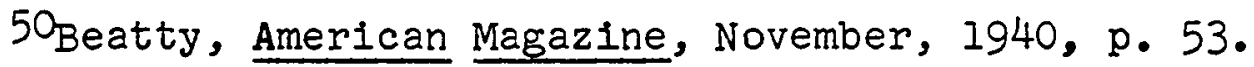

51 Ibid. 
211

General of the United States, Francis Biddle, issued a public warning on the same day of the Iitchfield, Illinois demonstration. Said Mr. Biddle:

A religious sect known as Jehovah's Witnesses has been repeatedly set upon and beaten. They had committed no crime, but the mob adjudged they had, and meted out punishment. The Attorney cieneral has ordered an immediate investigation of these outrages. There is no cause for mass hysteria, no justification for mob violence. 52

The anti-Witness outburst which swept the country after June 3, 1940, was not due altogether to the Gobitis decision. It is true that the decision gave impetus to the rising wave of persecution, but there were other causes involved. Without elaborating on these other causes, suffice it here to say that in 1940,53 the Jehovah's Witnesses themselves had intensified their campaign against various flag salute ordinances, and became more actively engaged in their street solicitation. Coupled with their stepped-up program to inform the public about certain "truths," the war in Europe was going badly for America's allies. There were unfavorable reports of $\mathrm{H}_{1}$ tler's march into the lowlands, the fall of Dunkirk, and the complete collapse of France. In less than eighteen months after the

52 The Solicitor General's speech was delivered coastto-coast over N.B.C. network on June 16, 1940. See Macmilian, Faith on the March, p. 226; Pike, Jehovah's Witnesses, 'p. 25; Beatty, American Magazine, November 1940, p. 54 .

53Date of Gobitis case. 
Gobitis decision, America's intervention into the war did not help to alleviate the intensity or the frequency of the punishment inflicted upon the Witnesses. It actually presented a more serious problem because the Jehovah's Witnesses refused to take an active part in the war effort. 54 Through the years of 1941 and 1942, the sacking of Kingdom Halls, and the burning of Witnesses' property continued. In Klamath Falls Oregon, on september 20, 1942:

A thousand townspeople laid a four-hour seige to a Jehovah's Witnesses convention today and then stormed the meeting in a riot of battered heads and club-swinging.

Patriotic music blaring from a sound truck spurred on the townspeople, who tossed stench bombs and rocks through windows of the convention building.

Four hundred members of Jehovah's Witnesses who as a matter of religious principle refuse to salute the flag or engage in outward forms of patriotism beat back the charge with staves from packing boxes. No one was seriousiy injured, but cut and bruised heads were plentiful. 55

On the same day in Iittle Rock, Arkansas, "twenty men attacked Jehovah's Witnesses who were holding a convention in a tourist camp. Two were shot and many injured."56 Describing this incident as "physically nauseating in its details," one of the publications explained the details of these outbursts.

54 The problem of conscientious objection led to many Supreme court cases. These cases and their implications are examined in a subsequent chapter.

$55_{\text {New }}$ York Times, September 21, 1942, p. ' 16. 56 Ibid. 
213

Occasionally another automobile would turn into the grounds. A dozen or more [men] pounced on each car and asked: 'Are you a Witness?' The usual answer came back in a firm voice: Yes I am a Witness.' The driver and other male occupants then were ordered out. Some hesitated. They were dragged out and the pummelling began. Many used their fists, but others wielded clubs, long heavy screw drivers, and black jacks. The beating usually continued until the victim fell.57

Conventions held by the Witnesses, which were annual affairs, were especially vulnerable to violent attacks. "The recent effort of this apocalyptic sect to hold simultaneous threeday conventions in many parts of the nation brought mob outbreaks in at least three cities."58 The occurrence of these incidents was too numerous and too widespread to record in detail without going beyond the bounds of this study. One thing more needs to be mentioned however in this wave of antiWitness hysteria. The persecution was not limited to physical violence. Although recorded information is sparce, the ostracism and petty discrimination suffered by these members of an unorthodox sect, if accurately reported, would produce a monumental volume. Undoubtedly, publicity itself may have distorted beyond reality the details of many incidents, but on the other hand, many others went unnoticed. There were numerous accounts dealing with the loss of employment, but only one event reached the national audience; and this was mainly due to governmental intervention. The clarksburg,

57 "Mob action Against Sect on the Increase," The Christian Century, LIX (October 7, 1942). 58 Ibid. 


\section{4}

West Virginia plant of the Pittsburg Plate Glass Company fired seven Jehovah's Witnesses for their unpatriotic activities. On the ground that the Nitnesses were unduly discriminated against, the President's Committee on Fair Employment Practices requested their reinstatement immediately. The company contended that seven hundred other employees had threatened a mass walkout unless these Witnesses were removed.

'Threatened violence or work stoppage to obtain the dismissal of capable employees whose religious convictions are unpopular with their fellow-employees does not constitute a valid reason for such dismissal,' the Committee held in a ruling which asserted the obligation and responsibility alike of management and labor organizations to protect workers from antagonism aroused by religious views. 59

It took five months to resolve the issue. 60 But this was only one of the many similar incidents which occurred throughout the country. In many cases, there was no reasonable means to prove that discrimination existed.

June 14, 1943, is a memorable date for the Jehovah's Witnesses, not only because the Court on that date disposed of several cases affecting the witnesses in their favor, but primarily because the decision reached by the court in the Gobitis case was overturned. It took three eventful years in which

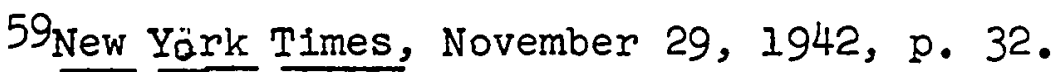

60 For a good treatment of this account see "Bias Charged in Firings," Business Week (December 26, 1942), p. 62 and its sequel, "Witnesses to be Rehired," Business Week, (April 10, 1943), p. 99. 


\section{5}

streams of societal pressures and human emotions poured under, over, and around the bridge of justice, to reach a reversal the magnitude of which was no less significant than the original opinion. The case of West Virginia state Board of Education et. al. v. Barnette et. al. 61 expressly overruled the Gobitis case. All of the details involved that led to the decision are too extensive to cover completely. But some of the more relevant aspects must be noted if the case is to be observed in a meaningful perspective. The public reaction engendered by the Gobitis case was already discussed at some length. Although the investigation has not been exhaustive, it aids in bringing the Barnette case into proper focus.

During the period between the Gobitis and the Barnette decisions, many occurrences seemed to have affected directly the final outcome of the flag salute controversy. Of these occurrences, three of them stand out as the most significant: First; the attitude and the action of the public. How much public reaction affected the decision of some of the justices is a moot point, and cannot be settled. It is established however, the public's Indignation was not entirely ignored by the Court. Justices Black and Douglas in their concurring opinion in Barnette noted that their decision was due -- in part -- to the resolute character of the Witnesses. They were convinced by the doggedness of the Jehovah's Witnesses to hold 
216

their ground, that the respondents were not attempting to show any disrespect to the flag or to their country. "The devoutness of their belief is evidenced by their willingness to suffer persecution and punishment, rather than make the pledge." 62 secondly; the "change of heart" of three justices, Black, Douglas and Murphy. In a surprising move, the three justices dissenting in Jones v. Opelika, ${ }^{63}$ a case dealing with Jehovah's Witnesses and the validity of licensing ordinances, said:

Since we joined in the opinion in the Gobitis case, we think this is an appropriate occasion to state that we now believe that it also was wrongly decided. 64

This was a public recantation, and certainly an unusual judicial procedure. In effect, the Justices were requesting another opportunity to decide on a similar case. And they did not have to wait long. Thirdly; there was during the interim a change of personnel on the bench. Justice James F. Byrnes resigned in october of 1942 after serving only one term, and in his place President Roosevelt appointed Wiley Rutledge

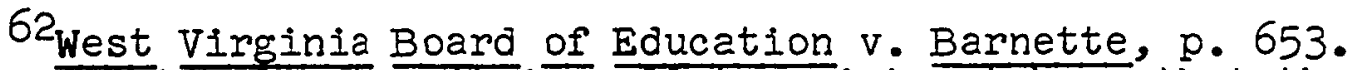
As a parenthetical note, it is well to point out here that the Murdock decision (discussed in another chapter), was delivered the previous month, and the division on the bench was identical to the division in the instant case. Another striking similarity is that both cases overturned a previous decision for basically the same reasons and social factors involved.

$$
\begin{aligned}
& 63316 \text { U.S. } 584 \text { (1942). } \\
& 64 \text { Ibid., pp. } 623-624 \text {. }
\end{aligned}
$$


217

effective February 15, 1943. When Rutledge came to the bench, the court was evenly divided on the flag salute issue; therefore he was the all important "balancer" of the scale. His appointment did not, however, turn out to be that crucial, for although Rutledge went along with the majority to overrile the previous decision, so did Jackson, who in the mean time, also suffered a change of heart, so much so that he was willing to write the majority opinion.

The Barnette case more than Gobitis, permitted the "friends of the court" to file motions and briefs in behalf of their side. The Committee on the Bill of Rights and the American Civil Liberties Union, as in the Gobitis case filed their briefs of amici curlae, and the American Iegion did likewise.

The Bill of Rights Committee of the American Bar Association filed a brief today in the West Virginia case attacking the Gobitis decision and the American legion filed a brief upholding it.

'The regulation forcing the (West Virginia) chilaren to engage in a ceremony which they believe to be sinful is an interference with religious liberty,' said the Bill of Rights Committee.

In American Legion brief Ralph B. Gregg of Indianar:olis, National Judge-Advocate, said that the salute 'does not engender in the mind of the individual the thought that the flag is an image to be worshipped, or that it is part of a religious right. 165

The Bill of Rights Committee felt that the Gobltis decision was wrong, not because of the harsh and unreasonable consequences which followed but because of:

$65_{\text {New York Times, }}$ March 9, 1943, p. 25. 
its fundamental fallacy. . . that any good result could be expected from attempting to force conformity to a particular ceremony, in the face of religious scruples. National unity is important, but the penalizing of religious beliefs held by a few school children is hardly the way to promote it. 66

Justice Jackson's majority opinion seems to have been motivated by this view to a large measure. Whether he formea his opinion before the briefs were presented, or whether he was influenced greatly by the argument presented by the Committee on Bill of Rights is academic as well as irrelevant.

In essence, there was no substantial difference in the facts involved between the Gobitis and Barnette cases. Following the Gobitis decision, the state of West Virginia amended its statutes to require the teaching of certain specific courses in its public schools such as history, civics and the constitution of the United States, "for the purpose of teaching, fostering and perpetuating the ideals, principles and spirit of Americanism, and increasing the knowledge of the organization and machinery of the government." 67 In accordance with the stated purpose, the Board of Education of the State adopted a resolution making the flag salute ceremony a regular part of the activities of the public schools. The failure to conform to this rule by some school children of the persuasion of Jehovah's Witnesses provided the action which brought the case

$66_{\text {B111 }}$ of Rights Review, I p. 268.

67 Quoted in West Virginia Board of Education v. Bar-

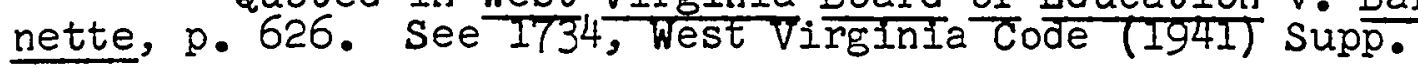


219

to the high court. Not only did the state law make it an "insubordination" to refuse to salute the flag, it subjected the childien to expulsion, thereby making them delinquents. The parents too vrere subject to conviction and fine.

The Board of Education filed for appeal to the supreme Court after a three-man District Court sustained the pleas of the Jehovah's Witnesses herein involved, to enjoin the enforcement of the ruling.

The opinion delivered by Justice Jackson may be divided into two areas. (1) His own interpretation of the central issue; (2) the attack -- point by point -- on Justice Frankfurter's majority opinion in the Gobitis case. It was significant to Jackson that, first of all, the freedom exercised by the appellees did not collide with the rights of others. In other words, the old issue of where the freedom of one enas and the freedom of another begins was absent in this case. The behavior was of a peaceabie nature, and no one was injured. The action of the state was especially offensive in that it compelied individuals to declare a belief.

There is no doubt that, in connection with the pledges, the flag salute is a form of utterance. Symbolism is a primitive but effective way of communicating ideas. The use of an emblem or flag to symbolize some system, idea, institutiun or personality, is a short cut from mind to mind. 68

Black and Douglas, on this same issue went further, for they 68 Ibid., p. 632. 
220

said, "Such a statutory exaction is a form of test oath, and the test oath has always been abhorrent in the United States. "69 The state then, did not have the power to require irjividuals to accept the political ideas represented in a symbol, by utterance, or by a ceremony which is nothing more than a short cut method of utterance.

To sustain the compulsory flag salute we are required to say that a Bill of Rights which guards the individual's right to speak his own mind, left it open to public authorities to compel him to utter what is not in his mind.70

Applying the clear and present danger test, Jackson claimed that the refusal to salute the flag did not create an inimical condition which would justify an effort to muffle expression. The whole content of this opinion was centered around the First Amendment. The due process clause of the Fourteenth Amendment might just as well have been ignored according to the reasoning of Jackson. He was concerned mainly with a more "terrible" power; that of compelling a person to accept certain beliefs against his will; it made no difference whether the issue was religious or political, neither did it make any difference whether the exercise of a ritual was "good, bad or merely innocuous." 71

$$
\begin{aligned}
& { }^{69} \text { Ibid., p. } 644 . \\
& 70_{\text {Ib1d., p. } 634 .} \\
& 7 I_{\text {Ibid. }}
\end{aligned}
$$


221

Hence validity of the asserted power to force an American citizen publicly to profess any statement or belief or to engage in any ceremony of assent to one, presents questions of power that must be considered independentiy of any idea we may have as to the utility of the ceremony in question. 72

According to the Gobitis case, a state could compel ANY child to salute the flag. It was this power which bothered Jackson. What was ussumed in Gobitis, he was only willing to "investigate" in the instant case.

After elaborating on what he considered to be an important distinction between Gobitis and Barnette, Jackson proceeded to refute Frankfurter's reasoning recorded in the Gobitis case. This he did somewhat methodically by examining each principle point. In his attack against the Gobitis majority, Jackson has furnished through his prose, the most quotable language in modern judicial literature. The import of his reasoning however valid, has been overshadowed by his remarkable phraseology.

1. Lincoln's dilemma, "must a government of necessity be too STRONG for the liberties of its people, or too WEAK to maintain its own existence?"73 was to Jackson an "oversimplification so handy in political debate [which] often lacks the precision necessary to postulates of judicial reasoning."74

$7^{2}$ Ibid.

73 Minersville v. Gobitis, p. 596.

74 West Virginia Board of Education v. Barnette, p. 636. 
222

Such a rule applied to this or any similar problem "would resolve every issue of power in favor of those in authority and would require us to override every liberty thought to weaken or delay execution of their policies."75 Finally, in calling for proper restrictions on governmental authority, he said, "Government of limited power need not be anemic government, "76 it is the assurance that rights are secure which "tends to diminish fear and jealousy of strong government, and by maxing us feel safe to live under it makes for its better support. "77 2. The notion that judicial interference with the activities of educational officers and their program "would in effect make us the school board for the country, "Jackson thought was exactly what the Fourteenth Amenoment permitted. To be sure, the numerous school boards throughout the country, and their myriad of minute problems and activities may not come under the scope of judicial scrutiny, but this does not mean that Boards of Eoucation are excepted. "There are village tyrants as well as village Hampdens, but none who acts under color of law is beyond reach of the constitution."78 To Jackson, the activities of local school boards, because of their provincial character and the lack of publicity, may go

75 Ibid.

$76^{\text {Ibid. }}$

77 Ibid.

78 Ibid., p. 638 . 
223

unnoticed by the public. Consequently the local authorities "may feel less sense of responsibility to the constitution, "79 and more likely to escape vigilance. Herein was reason enough for courts to scrutinize actions of school hoards.

3. The contention in Gobitis that the "courts possess no marked and certainly no controliing competence," 80 but to the legislature as well belongs the right to guard cherished liberties and the constitutionality of these liberties should be fought out in the form of public opinion and before legislative assemblies, Jackson regarded as somewhat peripheral. "The question whether the means of effecting political change are left free has nothing to do with the constitutional issue, for the freedoms of the Bill of Rights are beyond the reach of political majorities." 81 Frankfurter had said in the Gobitis case, liberty can be best preserved by free "effective means" in the legislative and public arena and not the judicial. Jackson's answer was not exactiy to the point, but it was not completely out of context.

One's right to life, liberty, and property, to free speech, a free press, freedom of worship and assembly, and other fundamental rights may not be submitted to vote; they depend on the outcome of no elections. 82

79 Ibid., p. 637.

80 Minersville v. Gobitis, pp. 597-598.

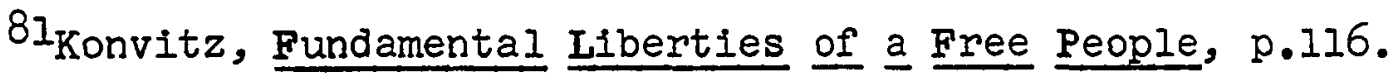

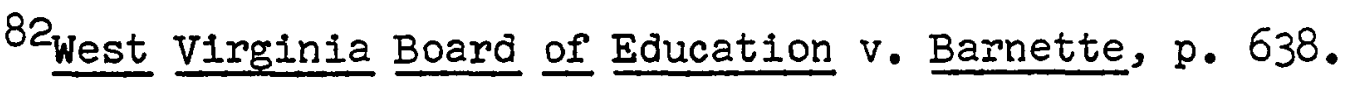


224

Jackson went further, and claimed that when legislation was being tested, it became more indefinite when it collided with the rights of the First Amendment through the Fourteenth Amendment, than when legislation collided only with the rights contained in the Fourteenth -- "much of the vagueness of the due process clause disappears when the specific prohibitions of the First become its standard." 83 That the court may render judgment over these matters, to Jackson, was not uncalled for; on the contrary, the court was instituted for that purpose. "W/e set in these matters not by authority of our competence but by force of our commissions." 84 It was not a question of whether the court was competent to adjudge, it was the Court's commissioned duty to act.

4. The last point covered by Justice Jackson was what he called the "heart of the Gobitis opinion." 85 His reference was to the statement that "national unity is the basis of national security," and the right of the authorities to "select appropriate means for its attainment."86 National duty as an end which officials may foster by persuasion and example was not open to question, but the problem here was whether the compulsory means employed for its achievement was within

\footnotetext{
83 Ibid., p. 640 .

${ }^{84}$ Ibid.

85 Ibid.

86 Minersville vo Gobitis, p. 595.
} 
constitutional bounds. Jackson, in refuting Frankfurter's argument applied the old ratio dicendi method. If at first moderate methods falled to achieve unity for national security, "those bent on its accomplishment must resort to an ever increasing severity. "87 The result would be, finally, "those who begin coercive elimination of dissent soon find themselves exterminating dissenters. Compulsory unification of opinion achieves only the unanimity of the graveyard." 88 Marvelous though it may sound, and quotable though it be, the phraseology does not answer the question of limitations which was the core of Justice Frankfurter's argument.

Jackson acknowledged that the case was difficult not because the principles were obscure, but because it involved a flag which was our own. While no one was opposed to the flag or to the teaching of patriotism through respect of the flag, such an end would not be injured by making the observance voluntary.

To believe that patriotism will not flourish if patriotic ceremonies are voluntary and spontaneous instead of a compulsory routine is to make an unflattering estimate of the appeal of our institutions to free minds. 89

This was the cry of a patriot to put faith in free institutions

87 Ibid., p. 640 .

$88_{\text {Ib1d., p. } 641 .}$

89 Ibid. 


\section{6}

and unfettered activity as the best means for the preservation of democratic values. If saluting the flag is an important exercise to safeguard an important characteristic of society, then so much more is voluntary activity to be protected; for the "freedom to differ is not limited to things that do not matter much. That would be a mere shadow of freedom." The real test of its substance "is the right to differ as to things that touch the heart of the existing order."90 Then with a dash of the superlative in judicial jargon, and a flair of constitutional theatrics, Jackson bequeathed upon posterity an effulgent First Amendment paean.

If there is any fixed star in our constitutional constellation, it is that no official, high or petty, can prescribe what shall be orthodox in politics, nationalism, religion, or other matters of opinion or force citizens to coniess by word or act their faith therein. If there are any circumstances which permit an exception, they do not now occur to us.91

The concurring opinion of Justices Black and Douglas was no more than an apology for joining the majority in the Gobitis case. It was their "reluctance to make the Federal Constitution a rigid bar against state regulation of conduct though inimical to the public welfare"92 that led to their decision, they said, But now they were convinced that the

$90_{\text {Ibid., p. } 642 .}$

9 Ibid.

92 Ibid., p. 643 . 
statute in question falled "to accord full scope to the freedom of religion secured to the appellees by the First and Fourteenth Amendments."93 This was a "spiritual condemnation," which, if groundless, only "time and reason are the proper antidotes."94 so saying, the Justices cast their vote against the Gobitis decision because they had suficient time to reanalyze the issue and conclude that a compulsory ceremonial in this instance was "a handy implement for disguised religious persecution."95

In a separate concurring opinion, Justice Murphy in effect, reiterated the opinion of Black and Douglas. He too, had time to think it over, and although was reluctant at first to interfere with state action, the interim provided time for a reevaluation of the whole issue. The end which the compulsory action sought, to be sure, was good, but here was involved a fundamental freedom, that of the right to believe and worship. "Reflection," said Murphy, "has convinced me that as a judge I have no loftier duty or responsibility than to uphold that spiritual freedom of its farthest reaches." 96 His whole argument was based on balance. The flag salute requirement, good as it may be as an important feature of public education, "I

$$
\begin{aligned}
& 93 \text { Ibid. } \\
& 94 \text { Ibid., p. } 644 . \\
& 95 \text { Ibid. } \\
& 96 \text { Ibid., p. } 645 .
\end{aligned}
$$




\section{8}

am compelled to conclude that such a requirement is not essential to the maintenance of effective government and orderly society."97 Not satisfied that his argument of balancing the good to be derived from compulsory action with the higher good to be realized by removing the shackles from freedom had been properiy appreciated, Murphy became redundant.

I am unable to agree that the benefits that may accrue to society from the compulsory salute are sufficiently definite and tangible to justify the invasion of freedom and privacy that is entailed or to compensate for a restraint on the freedom of the individual to be vocal or silent according to his conscience or personal inclination. 98

It cannot be said that the Justices who voted to strike down the constitutionality of the flag salute ordinance were themselves opposed to the act, or that they were unpatriotic. The question with which they wrangled was not patriotism, it was over the means by which patriotism would be best obtained. of course the main issue was whether the act itself was one which the Constitution prohibited, or in Frankfurter's terms, whether the Constitution locked with favor on the encroachment of the judiciary in the arena reserved for legislative struggle. Among the Justices there was no question that saluting the flag was a high privilege and a desirable exercise. Douglas

$$
\begin{aligned}
& 97 \text { Ibid. } \\
& 98_{\text {Ibid. }} \text {, p. } 646 .
\end{aligned}
$$


himself made this clear by saying in one of his several publications, "Most of us in America enjoy the flag salute ceremony. It is an exercise that always has new meaning, no matter how often we perform it."99 cast in such a light, the problem of compulsory flag salute becomes even more irreconcilable, for it seems that those who oppose a compulsory ritual are themselves the best practitioners of it.

The Court -- if unjustifiably -- then legally reversed the Gobitis decision. But not without a vogorous dissent from Mr. Justice Frankfurter who was not to be outoione by Jackson's eloquence or vehemence. The length of the dissent fades into the shadow of argumentation, for here, Frankfurter, again, put forth his best.

In a remarkably convincing dissent Frankfurter began by referring to his own background. His reference to a minority sect of which he himself was a member was a "deviation" that must have caused some discomfort to his colleagues. It was nevertheless timely and frank; judges after all, are human and not detached from prejudices. But judges "are neither Jew nor Gentile, neither Catholic nor agnostic. [ALL] owe equal attachment to the constitution and are equally bound by [their] judicial obligations whether [they] derive [their]

99w1liam 0. Douglas, We The Judges: Studies in Indian Constitutional Law from Marshall to Mukher je $\bar{a}$ (New York: Doubleday Co., In., 1956), p. 341. 
230

citizenship from the earliest or the latest immigrants to these shores."100 The Jewish heritage of the Justice has evoked some discussion as affecting his decision. Although not the main cause, some have felt that it was an important factor leading to his dissent.

Like the Jehovah's Witnesses the Jews were a minority group. For both, however, conforming with generalized regulations could not be turned into religious persecution. Speaking from the vantage point of his own background, Justice Frankfurter knew that minorities, as minorities, did not have to take umbrage at social regulations. Some of them at least had enough selfassurance to blend with the majority on many points.101

What the biographer is saying here is that, the Justice as a member of a majority, because of his own background and experience, was going out of his way to assure conformity. There is no merit in being recalcitrant just because the group to which one belongs is not in the general scheme of society. In other words, those who find themselves distinct from the majority, have a greater obligation to try to conform, than to emphasize their dissimilarity.

The personal honesty of the Justice, early in life led him to break with his own religious orthodoxy, thereby disquieting accusations that his judicial determinations were

100 West Virginia Board of Education v. Barnette, dissenting opinion, $\mathrm{p} .6 \mathrm{64}$.

101Thomas, Felix Frankfurter: Scholar on the Bench, p. 54 . 
231

colored by minority religious viess. If anything, his severance gave him a scope of view over religion not afforded the orthodox and the traditional. The Justice confided to one of his friends in a rare moment of such relations, that as a boy the "truth" came to him at a Yom Kippur service.

I remember with the greatest vividness thinking that it was unfair to me, a kind of desecration for me to be in the room with these people to whom these things had the meaning they had for them when for me they had no other meaning than adhering to a creed that meant something to my parents but had ceased to have meaning for me. . .

I left the service in the middle of it, never to return to this day. . .102

The psychological analysis of the Justice -- or any justice -has no basis whatsoever even in the remotest connection to this study, but in the light of the first statement made by the Justice in his dissenting opinion, the brief background information contained herein seems not to be altogether unwarranted. When the Justice began by saying, "One who belongs to the most vilified and persecuted minority in history is not likely to be insensible to the freedoms guaranteed by our constitution, "103 he was offering to his hearers an apologia unsolicited but deserving.

Frankfurter's attack against the Barnette majority began by an attack on the preferred position argument. The

102 Harlan B. Phillips, Felix Frankfurter Reminisces (New York: Reynal and Co., l960), p. 290 .

103 West Virginia Board of Education v. Barnette, p. 646. 
232

right not to have property taken without just compensation, and the right to be protected against unreasonable searches and seizures, have "the same constitutional dignity"104 so far as the scope of judicial power was concerned. And these rights have "no less claim than freedom of the press or freedom of speech or religious freedom."105 The core of his argument was limitations to constitutional power, in this case, as applicable to states by the judiciary. The question was really fairly simple; all that it involved was "the right of the state to compel participation in this exercise by those who choose to attend the public schools."106 In reviewing an action which the state had full authority to pass, "We are in fact passing judgment on the power of the state as a whole."I07 Frankfurter was thus taking "an extremely narrow view of judicial review of legislation."108 The only time when the court was justified in determining on the wisdom or evil of a statute was when there occurred some question of "whether legislators could in reason have enacted such a law."log He was undoubtedly calling for the application of the "reasonable man" rule.

The essential feature of the type of government set up

104 Ibid., p. 648.

105 Ibid.

106 Ibid., p. 650 .

107 Ibid.

108 Konvitz, Fundamental Liberties of a Free People, p. 117. 109West Virginia Board of Education v. Barnette, p. 651. 


\section{3}

by the framers of the Constitution was separation of powers, and the Court, according to Frankfurter had no business acting as the legislature even when the law passed by the legislature may not be wise.

If the function of this court is to be essentially no different from that of a legislature, if the considerations governing constitutional construction are to be substantially those that underlie legislation, then indeed judges should not have life tenure and they should be made directly responsible to the electorate.110

In his narrow view of judicial review over legislation, the Justice noted that the court could "only strike down. It can only say 'this or that law is void."Ill The court could not modify, qualify or "make exceptions to a general requirement."Il2 If Mr. Justice Jackson, in his majority opinion offered quotable statements, so too did Frankfurter in his dissent. "The constitutional protection of religious freedom," he said, "terminated disabilities, it did not create new privilege." 113 The essence of this guarantee, he continued, "is freedom from conformity to law because of religious dogma." 114 once the Court forsakes or disregards this responsibility, "each individual

$$
\begin{aligned}
& 110_{\text {Ibid., p. } 652 .} \\
& 111_{\text {Ibid., p. } 651 .} \\
& 112_{\text {Ibid. }} \\
& 113 \text { Ibid., p.653. } \\
& 114_{\text {Ibid. }}
\end{aligned}
$$




\section{4}

could set up his own censor against obedience to laws, conscientiously deemed for the public good by those whose business it is to make laws."Il5 The continuation of tinis trend would lead to a "subordination of the state on any matter deemed within the sovereignty of the religious conscience."116 Instead of preserving the tradition of separation of church and state, the former will emerge supreme as under a theocracy. What Frankfurter was calling for in effect, was separation of church from the forty-eight states without undue judicial interference.

The main judicial preceoent recognizing state authority over religious scruples was Hamilton $v$. Board of Regents of Californiall7 in which a unanimous court declared that one attending a state university could not refuse to attend courses that offended his religious convictions. Although other cases were cited, Frankfurter referred to this case in particular on numerous occasions to indicate that religious scruples were often not enough to invalidate reasonable legislation geared to an end which the legislature has a right to pursue. "I find it impossible," he said, "so far as constitutional power is concerned, to differentiate what was sanctioned in the Hamilton case from what is nullified in this case."ll8 If

115 Ibid.

116 Ibid., p. 654.

117293 U.S. 245 (1934).

118 West Virginia Board of Education v. Barnette, p. 657. 
California could compel compliance in a state-supported institution against a person's religious convictions why could not west Virginia compel a similar compliance? The two cases have been distinguished on the basis that attendance to an institution of higher learning is voluntary. But to Frankfurter the distinction was insignificant inasmuch as West Virginia could not compel attendance to public schools anyway. 119

Being cognizant of some of the cases brought before the state courts,Frankfurter displaying keen foresight foretold of some things to come. The Barnette decision, he felt, would open Pandora's Box and when such disputes as religious education in public schools, Bible-reading in classes, and the question of state support over bus fares and testbooks 120 arose, the Court would be at a quandary as to how the issues would be settled. The court then would really become a "school boaro" and a regulatory agency. Frankfurter remarked that the court must decide on the instant case, but "We must decide this case with due regard for what went before and no less regard for what may come after."121 If for nothing else, than for the

${ }^{119}$ See Pierce v. Society of Sisters, 268 U.S. 510 (1925). 120 Some of the cases which were brought before the court later dealing with these issues were: McCollum v. Board of Education, supra; Everson v. Board of Education of New Jersey, 330 U.S. 1 (1947), and Zorach v. Clanson, 343 U.S. 306 (1952). 661. ${ }^{12} 1_{\text {West Virginia Board }}$ of Education v. Barnette, $p$. 
236

sake of an orderly pattern of a rule of law to be applied in similar cases, it would fustify permitting the legislature to decide the methods to be employed for the teaching and promotion of good citizenship. As was argued by the majority, if symbolism is a primitive way of communicating ideas, then we are aII doomed to primitive methods for "even the most sophisticated live by symbols." 122 The contention that saluting the flag was equal to saluting a dictator Frankfurter said was a "flippant suggestion," of the irresponsible. "The significance of a symbol lies in what it represents. To reject the swastika does not imply rejection of the Cross."123 Continuing his rebutial, the Justice declared that neither does the flag salute exercise have any "kinship whatever to the oath tests so odious in history." For the oath test was one of the instruments for suppressing heretical heliefs. Saluting the flag suppresses no belief nor curbs it." 124

In referring to the "clear and present danger" argument Frankfurter assailed the majority for misconstruing the rule. It could not, in proper context, be used against the power of the state to regulate.

To talk about 'clear and present danger' as the touchstone of allowable educational policy by the states whenever school curricula may infringe

122 Ibid., p. 662 .

123 Ib1d.

124 Ib1d., pp. 663-664. 
upon the boundaries of individual conscience, is to take a felicitous phrase out of the context of the particular situation where it arose and for which it was adapted.125

Realizing the importance of stare decisis in Anglo Saxon jurisprudence, Frankfurter presented a strong case for the adherence to former decisions. He noted that previous to the instant decision there were five cases brought before the Supreme Court involving the right of states to require the flag salute exercise. 126 Applying simple mathematics he submitted that:

What may be even more significant than this uniform recognition of state authority is the fact that every Justice -- thirteen in all -- who has hitherto participated in judging this matter has at one or more times found no constitutional infirmity in what is now condemned.127

Furthermore, this principle was recognized by men like Chief Justice Hughes, Justice Brandeis, and Justice Cardozo, to name some who were not then on the bench. Frankfurter did not hide his irritation for he said that "only two Justices

$$
125 \text { Ibid., p. } 663 .
$$

126The first three cases were dismissed by the high court for want of a substantial federal question; Leules v. Landers, 302 U.S. 656 (1937), Hering v. State Board of Education, 303 U.S. 624 (1938), and Gabrielli v. Knickerbocker, 306 U.S. 621 (i939). In the fourth case the judgment of the lower court was summarily upheld on the authority of the earlier cases. Johnson v. Deerfeld, 306 U.S. 621 (1939). The fifth case was Minersville $\mathrm{v}$. Eoblt1s, supra., the only one of the five in which any dissent was recorded.

127 West Virginia Board of Education v. Barnette, p. 665. 
238

sitting for the first time on this matter have not heretofore found this legislation inoffensive to the 'Iiberty' guaranteed by the Constitution."128 All others by implication, only showed their incompetence. Frankfurter's reference to Hughes, Brandeis and Cardozo was not altogether unfounded, for the former Chief Justice. Hughes, wrote to him and said that his dissent represented the line of reasoning that would have been pursued by Cardozo, Brandeis and even Holmes. 129 To Frankfurter it was intolerable that "That which three years ago had seemed to five successive Courts to lie within permissible areas of legislation is now outlawed by the deciding shift of opinion of two Justices."130 The reference here was obviously to Justices Jackson and Murphy. Holding fast the doctrine of gradualism (perhaps perpetuity) of the development of law, Frankfurter warned his colleagues that "The Court has no reason for existence if it merely reflects the pressures of the day. "I3I

In his concluding remarks, Frankfurter quoted from James Bradley Thayer: "there has developed a vast and growing increase of judicial interference with legislation." 132 Then as a reminder that he too was in favor of a free and liberal

128 Ibid.

129Letter from Hughes to Frankfurter, June 17, 1943. Quoted in Thomas, Felix Frankfurter: Scholar on the Bench, p. 55 .

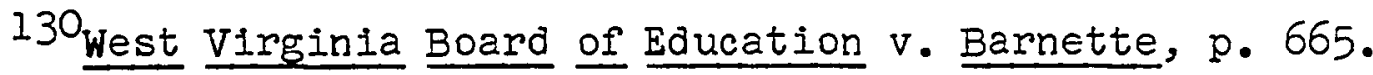

13IIbid.

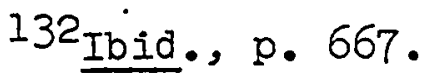


239

spirit he opined, "Of course patriotism can not be enforced by the flag salute. But neither can the liberal spirit be enforced by judicial invalidation of illiberal legislation."133 A law is not all right just because it is constitutional. "Such an attitude is a great enemy of liberalism." I34 No doubt, Mr. Justice Frankfurter was deeply involved in the flag salute cases. No other Justice seems to have been so intense over the issue. One of the writers who probably disagreed with Frankfurter called the dissent a "remarkable testimonial" which indicated "deep emotional involvement."135 For a person who was personally involveo, there was nothing to indicate that there was personal prejudice over certain religious groups or certain rights over others. Certainly:

There was no suggestion that the Jehovah's Witnesses who refused to participate were necessarily unpatriotic. The position taken was that paying respect to the flag as a symbol was ONE way in which social cohesion and national feeling could be prompted. It was the legislative judgment that generalized regulations employing symbolic techniques should be valid for every one in the public schools. 136

The Barnette majority, in the opinion of Frankfurter, was making a dangerous exception. "The good order and weIfare of the other children in the classroom were also at stake when

\section{Ibid., p。670.}

134 Ibid.

135Mas on, The Supreme Court, From Taft to Warren, p. 143. 136 Thomas, Felix Frankfurter: Scholar on the Bench, pp. $57-58$. 
exemptions were made." 137 He intimated that the supreme Court also had responsibility for the ninety and nine who were not Jehovah's Witnesses.138

The flag salute cases more than any other compel an evaluation of the participating Justices. Such practice, although uncailed for, is not altogether inappropriate, especialiy in the light of the remarks of a personal nature made by the Justices themselves. The present study is not directed toward the examination of Justices, and therefore, it has been kept to a minimum. Frankfurter, of course, deserves the bulk of the concentration, and this study to a certain degree corroborates that assertion. The difficulty arises because the Supreme Court is composed of men and not installed with computing devices. Were we to depend upon robots or mechanical devices for decisions, the examination would be comparatively simple. But Justices are not automatons subject to examination by precise gauges. Were the gauges available, it is inconceivable that they would measure the ability and aspirations of Justices to preserve the good of society in the context of a constitutional scheme. Of necessity, we succumb to the use of the inaccurate gauge of subjective judgment and reach for temporary conclusions. The examination is not wholly in vain however, for the study of the men of the bench is rewarding in many ways.

$$
\begin{aligned}
& { }^{137} \text { Ibid.., p. } 58 . \\
& { }^{138_{\text {Ibid.., pp. }}} \text { 58-59. }
\end{aligned}
$$


241

On the same day that the Barnette decision was delivered, the Court also disposed of another flag salute case, Taylor v. Mississippi. 139 The American Civil Liberties Union in behalf of the appellants filed a brief of amicus curiae urging a reversal of state action. It goes without saying that the momentousness of the Barnette case relegates the instant case to obscurity.

The case involved three members of Jehovah's Witnesses in three separate counties engaging in the practice of attempting to create in their listeners "an attitude of stubborn refusal to salute, honor or respect the flag of the government of the United States or of the State of Mississippi."140 The anti-sedition law of Mississippi specifically prohibited such practice. Taylor, one of the appellants was charged in Madison County court for violation of the statute. The prosecution showed evidence that in the course of his interviews with some women, two of whom had a son killed in the war, he stated that it was wrong to fight our enemies. And that the women's sons were shot down for no purpose at all. The war would come to a quicker conclusion of people would quit "bowing down and worshipping and saluting our flag." 141 The second appellant, Betty Benoit was charged before the Marion County

$$
\begin{aligned}
& 139319 \text { U.S. } 583 \text { (1943). } \\
& 140_{\text {Ibid., p. } 584 .} \\
& 14 I_{\text {Ibid., p. } 586 .}
\end{aligned}
$$


242

Circuit Court for a similar violation. In her case however, she was distributing a watchtower publication called "Consolation" which criticized the Gobitis decision and called for righteous disobedience. The salute to the national flag according to this view amounted to a form of primitive idol worship. Such worship originated in Catholic schools of France, and even the practice in the United States was covertly urged by the Roman Catholic hierarchy.

The third appellant, Cummings, was charged with violation of the same anti-sedition. Statute in the warren County Circuit Court. He was engaged in passing out a pamphlet entitled "Children," in which the central theme was the influence of Satan over public officials. Knowing that time was short, Satan had influenced the magistrates to compel little children to indulge in idolatrous practices of bowing down to some thing, such as the flag.

All three cases were heard together, and Mr. Justice Roberts spoke for a unanimous Court. The core of the opinion was that if the flag salute ceremony could not be constitutionally compelled, its advocacy could hardy be made a crime.

If the Fourteenth Amendment bans eniorcement of the school regulation, a fortiori it prohibits the imposition of punishment for urging and advising that, on religious grounds, citizens refrain from saluting the flag. 142

The court refused to go along with the state in its contention

142 Ibid., p. 589. 
243

that the appellants advocated or incited subversive action against the nation or the state, or that they had threatened any clear and present danger to free institutions. "What these appellants communicated," said Roberts, were their beliefs and opinions concerning domestic measures and trends in national and world affairs."143

In conformity with the reasoning in Barnette, the Court declared in the instant case, the conviction of the appellants under the anti-sedition statute of Mississippi deprived them of their rights to freedom of speech and press guaranteed by the First Amendment.

The Barnette and Taylor cases were decided on June 14, 1943. Several months later, on October 18, 1943, the court again heard a flag salute case 144 on a writ of certiorari. In a per curiam decision the Court made reference to previous flag salute cases (examined above) and vacated judgment and remanded the case to the state courts for further consideration in the light of the high court's previous decisions.

So ended -- at least for the time being -- an era which witnessed a series of cases and a long train of briefs and arguments over the legality and merits of saluting the flag by compulsory decrees. The cases examined in this chapter tell

$143_{\text {Ibid., }}$. 590 .

144Mathews et. al., v. West Virginia ex. rel. Hamilton, Prosecuting Attorney, 320 U.S. 707 (1943). 
244

only part of the story of a struggle to establish an orderly legal pattern in line with acceptable social norms. The numerous cases which never reached the Supreme Court, and the activity of the public in general mist go unheeded here either because they are beyond the scope of this study, or the experiences have not been recorded. 


\section{CHAPTER VIII}

\section{PEDDLING VS. PRIVATE PROPERTY}

The sanctity of property is a notion not alien to the principles incorporated in the American Constitution by its framers. The clarification of this notion in the context of political complexities and economic growth has necessitated numerous judicial decrees. In this evolutionary process, slowly but with certitude the court has tended to delineate and preserve individual rights over ard against the right of property. This trend has not always been discernible, but the "long look" oven constitutional development tends to corroborate this view. Toward this development the Jehovah's Witnesses too, made important inroads.

The United States Supreme Court, in a littlenoticed majority opinion by $\mathrm{Mr}$. Justice Black, recently took another long step toward the permanent safeguarding of our democratic rights. The Court ruled that a member of Jehovah's Witnesses was within her rights in distributing religious literature on the sidewalk of a company town in Mobile County, Alabama, and not liable to arrest for trespassing on private property. I

If this case has been "little-noticed," it belies and obscures the real import and weight of its constitutional consequence. Marsh v. Alabama, ${ }^{2}$ was "the first case to

I"Civil Rights and Property," New Republic CXIV (Jan. 21, 1946), p. 69 .

$2_{326}$ U.S. 501 (1946). 


\section{6}

extend by law the privilege of religious excercises beyond public places or to private places without the assent of the owner."3

The case arose from the action of a Jehovah's Witness who was engaged in the dissemination of religious literature in a company-owned town known as Chickasaw; a suburb of Mobile, Alabama. The town was owned by the Gulf Shipbuilding Corporation, and "had all the features of any American town." 4 There were residentail buildings, a system of streets and sewers, and even a "business block" on which the business houses were situated. One of the buildings was used by the United States government as a post of 1 ice, and six men were employed as mail carriers to distribute the mail in the town of Chickasaw. From outward appearances the Gulf property was not distinguishable from other public places, and the residents used the business block as their regular shopping center. A four-lane public highway intersected the private roads in one section of the town. There was nothing to prevent travelers from entering the town and carrying on general trading, which so many of them did. The important fact remains however, this was a company-owned town, and thus belonged to a private corporation.

The appellant, a Jehovah's Witness, came onto a sidewalk

IIbid., p. 512. Dissenting Opinion by Mr. Justice Reed. ${ }^{4}$ Ibid., p. 502 . 
247

near the post office and undertook to distribute literature. The Corporation had posted signs in the nearby stores which read, "This is Private Property, and Without Written Permission, no Street or House Vendor, Agent or Solicitation of Any Kind Will Be Permitted." The appellant was warned that she could not distribute literature, and was also told that she could not obtain a permit. She was then asked to leave the particular oremise, and when she refused, she was arrested and charged with violation of a state ordinance which made it a crime to enter or remain on a premise after being warned not to do so. The petitioner contended that, the act abridged her freedom of press and relificion which were protected by the First and Fourteenth Amendments. The case came to the Supreme Court on appeal after an Alabama Appeals Court upheld the conviction, and certiorari was denied by the State supreme court. In delivering the majority opinion of a five to three civision on the Court, Mr. Justice Black stated the constitutional question in the following manner:

In this case we are asked to decide whether a state, consistently with the First and Fourteenth Amendments, can impose criminal punishment on a person who undertakes to distribute religious literature on the premises of a company-owned town contrary to the wishes of the town's management. 5

Or as Mr. Justice Black further narrowed the question, "Can 
248

the people who live in or come to Chickasaw be denied freedom of press and religion simply because a single company has legal title to all the town?

It would have been a fairly simple question to settle, as the Court noted, had the action occurred in a public municipality. ${ }^{6}$ A company-owned town in this case was no different than a public municipal corporation however, therefore the judgment rendered upon public towns was controlling in this case. While it is to be assumed that private ownership bestows the right on the owner to control, the court was quick to point out that "ownership does not always mean absolute dominion."7 Furthermore, the court refused to go along with the contention that the corporation's right to control the inhabitants of Chickasaw was equal to that of the homeowner to regulate the conduct of his guests. Although not immediately visible, herein lies the distinction of the present case. What the court was saying, in effect, was that the sanctity of property is dependent upon usage; the extent of this "privacy" is inversely proportional to the degree to which the property was

The cases to which the Court had reference were: Hague v. C.I.O., Schneider v. Irvington, Thornhill v. Alabama, CantweII v. Connecticut, Largent v. Texas, Jamison v. Texas, supra., Murdock V. Pennsylvania, and the dissenting opinion of Justice Stone In Jones v. Opelika, which became the majority decision in the second opelika case, supra. It would be well to note here that in the instant case, Justice Reed's dissentIng opinion was also based on these same precedents. Reed's conclusion being that although these cases permitted free distribution they were quite clear in permitting such distribution only in public places.

7 Marsh v. Alabama, p. 506. 
used by the public.

The more the owner, for his advantage, opens up his property for use by the public in general, the more do his rights become circumscribed by the statutory and constitutional rights of those who use it. 8

Such a daring doctrine could properly anticipate a decision favoring minority groups seeking services in all private places including theatres, restuarants, hotels and similar private concerns. While it is not within the scope of this study to examine cases other than those affecting the Jehovah's Witnesses, it is gratifyingly pertinent to observe that the decisions from the cases affecting the Witnesses seem to provide the answers to problems arising years hence. The problem of exercising individual liberties in company town, to be sure, was not novel with the Jehovah's Witnesses. The United States Congress carried on an extensive investigation over the mistreatment of individuals in company towns long before the Witnesses presented their case.9 Most of the early problems arose from the difficulties involved dith laboring groups.10

\section{Ibid.}

9U.S. Congress, Senate, Committee on Education and Labor, Violations of Pree Speech and Rights of Labor, S. Res. 226, part II, 74th cong., 1937, pp. 3944-3950, 3957-3971.

10 For a short but excellent treatment of this problem, see. Witt Bowden, "Freedom for the Wate Earners," Annals, CC (Nov., 1938), pp. 185-209. The author, an economist with the Bureau of Labor Statistics in the United States Department of Labor, documents his analysis mainly with the hearings conducted in congress. The denial of civil liberties in companyowned towns are spelled out in detail. 


\section{0}

Taking an active role in the disputes, the National Labor Relations Board, a year before the Marsh case, charged an employer with unfair labor practices for enforcing "a 'no solicitation' rule against the solicitation of union membership by employees on company property."II The Supreme Court declared that the action of the N.L.R.B. was warranted. Two years after Marsh, the Court again upheld the Board action when it charged an employer with unfair labor practices for denying a labor organization the use of a company-owned meeting hall in a company town.12 Speaking of Marsh:

none of the cases have so squarely raised the issue of personal property rights as does this instant case. An earlier Supreme Court decision had prevented a city from penalizing the ringing of doorbells, relying inter alia, on the reasoning that the preference as to whom he wants on his property should rest with the owner. Since this choice was made clear by the company in the instant case, and since it clearly owned the community in Alabama, it might seem to follow, without raising constitutional issues, that its ownership gave it this traditional homeowner's right to exclude unwanted visitors.13

It is this reasoning which "might seem to follow," and does

${ }^{11}$ Republic Aviation Corp. v. N.L.R.B. 324 U.S. 793 (1945), p. 793. The case was heard together with N.L.R.B. v. Le Tourneau Company of Georgia. $226(1948)$.

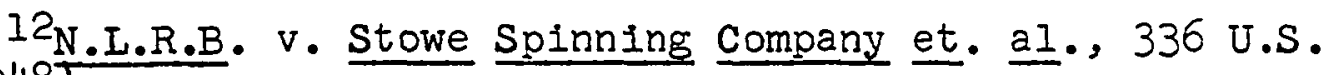

13 "Freedom of Speech -- Jehovah's Witnesses," Columbia Law Review XLVI (May, 1946) p. 458. 
251

not follow, that makes Marsh a momentous case. It is not just an exception, it becomes a general rule.

a company town is not a private home, but a town, and a holding contrary to that of the instant case would lead to the result that the constitutional rights of visitors in Chickasaw would be denied where a company had title but not where a municipality did. 14

The majority of the court thought that wherever and whenever facilities were built and operated primarily to benefit the public and the sustenance of the facilities was depenoent upon it, such as in the case of bridges, ferries, and turnpikes, the state had the right to control.15 The case of a company-owned town came under the same general classification, at least for the purpose of a judicial decision. In connection with this reasoning, and the fact that a public highway intersected the streets of Chickasaw, the Court pointed to interstate commerce as having some bearing although not controlling the decision. Mr. Justice Frankfurter, concurring with the majority opinion felt that the commerce clause was completely irrelevant and alien to the issue at hand. He felt that the commerce clause involved an "accommodation" of state and

\section{$14^{\text {Ibid. }}$}

15The principle cases applicable to this reasoning as indicated by the court are: Clark's Ferry Bridge Company v. Public Service Commission, 291 U.S. 227 (1934), American Toll Bridge Company $v$. Railroad Commission of California et. al.,

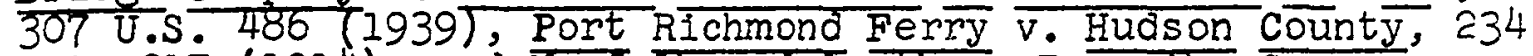
U.S. 317 (1914), and Noriolk and Southern Turnpike Company v. Virginia 225 U.S. 265 (I9I2). 
252

national powers, whereas the First Amendment as applied here had to do with the denial of all governmental power. Frankfurter, strange as it may seem, did go along with the "preferred position" argument presented by Mr. Justice Black. As has been observed elsewhere, Frankfurter has never been a supporter of the preferred position argument. But in this case he felt that certain previous cases established the preferred position ruling, and if such a measure could be accorded First Amendment freedoms at all, it should be invoked in the instant case. Thus the learned Justice, although unfavorable to a principle, decided in favor of it on the basis that great weight should be accorded established rules and practices.

In the eyes of the majority, Chickasaw was just another average American town. The "business block" was especially the noticeable pattern in this scheme of appearance. The residents of the community were average, ordinary American citizens entitled to all the liberties provided by the Constitution. Thus the Court said, "There is no more reason for depriving these people of liberties guaranteed by the First and Fourteenth Amendments than there is for curtailing these freedoms with respect to any other citizen." 16 sensing the importance of the issue of property, the court again referred to the argument of "balance."

When we balance the Constitutional rights of

16 
253

owners of property against those of the people to enjoy freedom of press and religion, as we must here, we remain mindful of the fact that the latter occupy a preferred position.17

On this issue Frankfurter provided a terse statement which, in effect, nullified the argument of balance; "Title to property as defined by state law controls property relations; it cannot control issues of civil liberties. . "18 To Frankfurter, the case was a clear cut issue involving civil liberties; while according to the majority opinion property rights were also involved, with civil liberties considerations outbalancing the rights of property. To state it in different terms:

The general question posed by the [majority opinion] might be phrased in terms of the inroads on the right of property that are reasonably necessary for protection of the preferred constitutional rights involved. 19

The dissenting opinion was delivered by Mr. Justice Reed, concurred in by Chief Justice Stone and Justice Burton, with Justice Jackson taking no part in the decision. Noting that religious activities have been accorded preferred treatment, Reed also acknowledged that previous cases 20 established the right of individuals to distribute religious literature in public

\footnotetext{
$17_{\text {Ibid., p. } 509 .}$

18 Ibid., p. 511.

${ }^{19}$ Columbia Law Review, XIVI, p. 459.

20 see note 6 .
} 


\section{4}

without being restricted to permits and licenses when the pubIic interest is not directly jeopardized. But in this case, said the Justice, "the decision establishes the principle that one may remain on private property against the will of the owner and contrary to the law of the state. . "2l This extension of privilege was unwarranted and constituted an encroachment upon the rights incident to private ownership. Reed went so far as to say that even when the restrictions imposed by the owner of a property may be "galling" and appear unreasonable, "unless they fall under the prohibition of some legal rule, they are a matter fo: adjustment between owner and licensee, or by appropriate legislation."22 One other consideration was important in the dissent. The appellant was free to engage in his practice on the public highways which were not distant from the street where she actualiy undertook her endeavor, and, had she done so, the purpose for which she undertook the act would have been accumplished without becoming a tresspasser on company-owned property. The Constitution gave protection of property to the owner, and this right which the Constitution protects, is "not outweighed by the interests of the tresspasser, even though he tresspasses in behalf of religion or free speech." 23 It is this traditionally revered

$$
\begin{aligned}
& 21_{\text {Marsh }} \text { v. Alabama, p. } 512 . \\
& 22 \text { Ibid., p. } 513 . \\
& \text { 23 }{ }_{\text {Ibid., p. } 516 .}
\end{aligned}
$$


255

view of property which was modified by the instant case. In a broader sense, the Supreme court "set aside the conviction on the ground that the state act was used here to accomplish an unconstitutional restriction on freedom of religion and the press." 24

In a similar cose25 decided on the same day, the supreme Court, for the same reasons offered in the Marsh case, set aside the conviction of a Jehovah's Witness who was convicted under a Texas statute for distributing literature in a Federal Housing area. Hondo Navigation Village, located in Medina County, Texas, was the cite in which the tresspass occurred. The Texas penal code made it an offense for any "peddler" or "hawker" of goods or merchandise to refuse to leave premises after having been notified to do so. The appellant, first of all, claimed that he was neither a "peddler" nor a "hawker" but a minister of the gospel engaged in the distribution of literature to those who would receive them. His constitutional contention was that he was denied his rights of press and religion as guaranteed by the First and Fourteenth Amendments.

The area in which the appellant was engaged in his work was a housing area provided for persons engaged in National

24 Milton R. Konvitz and Theodore Leskes, A Century of Civil Rights (New York: Columbia Univ. Press, 1961), p. 145. 25 $\underline{\text { Tucker v. Texas, }} 326$ U.S. 517 (1946). 


\section{6}

Defense activities. The Federal Housing Authority had placed the area under the direction of a manager whose duty it was to collect rents and supervise the general activities subject to the direction of the authority. It was the manager who had refused to grant the appeliant permission to distribute literature in the area and upon the appellant's refusal to comply, ordered him to leave the village. The Medina County Court convicted the appellant deeming his activity sufficient to be subject under the state Statute. Since the case could not be appealed to a higher state court, the Supreme Court accepted the case on appeal. After the decision rendered by the court in the Marsh case, the disposition of this case presented no serious problem. The High Bench divided exactly as it did in the Marsh case, with shorter recorded opinions. The majority opinion noted that:

The only difference between this and Marsh v. Alabama is that here instead of a private corporation, the Federal Government owns and operates the village. This difference does not affect the result.26

The Court said under certain conditions, it may be necessary to isolate Federal settlements, but such a necessity was not demonstrated here. Neither the Act of Congress nor the Public Aousing Authority had shown any intention of refusing religious activities of the type carried on by the appellant.

${ }^{26}$ Ibid., p. 520. 
Although, the Tucker case is no different substantially from the Marsh case, there was a distinction which the court noted but refused to apply as controlling. And this distinction was the Act of Congress which established the village. Justice Black, delivering the Court's opinion said that in the absence of specific provisions, there was no reason to assume that the Act prohibited religious activities. Frankfurter, concurring with the majority said, "it will be time enough to consider the constitutionality of the Act of Congress," 27 when the occasion presents itself. The Chief Justice and Justices Reed and Burton dissented on the ground that the Federal Housing area had "not been shown to be dedicated to general use by the public." 28

Both cases established the same constitutional conclusion. Other than the all important modification of the doctrine of property rights, these cases established two general rules. (1) A state cannot, without violating the privisions of the First and Fourteenth Amendments, impose criminal punishment on persons distributing religious literature in a companyowned town where the business district is freely accessible to the public in general. (2) Inhabitants of a company-owned town are free citizens of their state and cannot be deprived of their liberties guaranteed by the constitution any more

$$
\begin{aligned}
& 27 \text { Ibid. } \\
& 28 \text { Ibid., p. } 521 .
\end{aligned}
$$


258

than the residents of public municipalities. Both of the above are applicable to Federal Housing areas.

In appraising the importance of these two cases, the Christian Century pointed out soon after these decisions had been made public:

Two years ago Judge Edward F. waite, writing in Minnesota Law Review, pointed out how the thirty-one cases Involving Jehovah's Witnesses which had come before the Supreme Court since 1938, had enlarged the concept of American civil liberties, including liberty of conscience. Two more Witness cases just decided by the supreme Court continue the record. In each the court, by identical five to three votes, held property rights subordinate to freedom of religion.29

Another "notable fact" according to the Century was the position of Justice Frankfurter, 30 who sided with the majority in a case which upheld the "preferred position" and restricted the rights of property. However unjust or deserving the criticism against the Justice, it must be said that his decision was based on the rule of at least three cases.31 If these cases express the law of the Constitution, Frankfurter could not see why application of the law expressed therein would be much different in a company-owned town. This means that

29"Jehovah's Witnesses cases Extend Religious Liberty," Christian Century IXIII (Jan. 23, 1946), p. 100. The article by Waite mentloned herein appears elsewhere in this study.

30 Ibid.

3lMartin v. Struthers, Murdock v: Pennsylvania, Jones v. Opelika, The discussion of these cases appears elsewhere in this study. 
259

Frankfurter may not have been altogether favorable to the decision, he may have been completely opposed; but he was applying the law established in previous cases, and not to determine (again) the constitutional validity of the decisions already passed upon.

The Marsh and Tucker decisions indicate the broad scope of activity the court was willing to grant religious groups, even to permit them free exercise in a privately owned community. "When an owner opens up his property for use by the public, his rights become circumscribed by the statutory and constitutional rights of those who use it."32 The judgment of the court was based mainly on the fact that private property, as in the case of a company town had as an essential element a service function. It was this responsibility to the public that made a company-owned town indistinguishable from a public municpality for purposes of preserving constitutional guarantees.

32Robert E. Cushman, "Constitutional Law in 1945-1946," A.P.S.R., XLV (April, 1947), p. 266. 


\section{CHAPTER IX \\ CONSCRIPTION AND CONSCIENCE}

"The legal framework within which the conscientious objector acted was built up slowly and with many seeming contradictions." I To this development, the Jehovah's Witnesses made a constitutional contribution which has been obscured somewhat by the extent of their relentless attempts to convince the court that they were being denied constitutional guarantees. The problem of conscientious objection was certainly not peculiar to the Jehovah's Witnesses alone, and they were not novel contributors of constitutional principles in that area. They represented only one of the many groups in this country who refused to go to war, or to aid in the war effort for various reasons.

On the surface it would appear that these cases would have been considered under First Amendment guarantees inasmuch as the Jehovah's Witnesses came under the protection of the "religion" clause of the First Amendment. But unlike other Jehovah's Witnesses cases, the conscientious objector cases involved something else, namely, administrative procedure.

IFlulford Q. Sibley, and Philip E. Jacob, Conscription of Conscience (Ithaca: Cornell University Press, 1952), p. 419. This is by far the best work on conscientious objectors to date. It is of course restricted to the World War II period and deals with all groups who objected to military service for conscience' sake. While the cases involving Jehovah's Witnesses are treated adequately up to that period, since many cases arose after the book was published, the treatment is naturally incomplete. 
261

On a broad basis there are two groups of conscientious objectors, the fundamentalist and the humanitarian. Briefly, the fundamentalists (Jehovah's witnesses belong to this group) believe in the biblical war of Armageddon, and will adhere strictly to God's injunction even if by doing so "they accomplish no positive good on earth." 2 The humanitarians on the other hand believe in spreading the gospel of love rather than force. In a way, they are the true pacifists, since they do not believe even in a "holy" war as do the fundamentalists. Constitutionaly, this distinction has no material value, hence the court did not deal with this problem. However, to the Jehovah's Witnesses this was an important issue and it was the underlying cause of their irksome demands before the courts.

From the viewpoint of the state, Jehovah's witnesses were to prove perhaps the most troublesome of all those groups that could, broadly speaking, be called 'conscientious objector.' 3

Although the issue of conscientious objection was most proncunced during the two World Wars, the Jehovah's Witnesses did not cause much legal difficulty in the midst of the war

2William Fifield, "Report from a Conscientious objector," Harper's Magazine, CXC (Jan., 1945), p. 190. The distinction between a fundamentalist and humanitarian conscientious objector has been extracted from the content of this article. See also Joseph L. Blau, Cornerstones of Religious Freedom in America (Boston: Beacon Press, 1950), p. 5 .

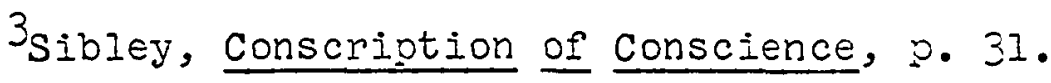


years. Many were imprisoned to be sure, but there was no supreme Court case involving Jehovah's Witnesses during World War I, and it was not until the latter period of World War II that the first Jehovah's Witnesses case of conscientious objection came before the high court. It is true, and significant to constitutional analysis that many Jehovah's Witnesses were in prison for conscientious objection all during the years of World War II.

Two-thirds of nearly five-thousand conscientious objectors who have been sentenced to prison are Jehovah's Witnesses who as a group asked for ministerial deferment and were refused. 4

According to Sibley and Jacob, more than three-quarters of the conscientious objectors who on various grounds were imprisoned, were Jehovah's Witnesses. 5 This of course does not mean that they were more vigorous in their beliefs than members of other pacifistic groups. Many conscientious objectors belonging to other religious groups gladly served as noncombatants, while the Jehovah's Witnesses were generally opposed to all service relating to the war effort. This seems to be a condition -certainly a distinction -- inherent in the difference between a fundamentalist conscientious objector and a humanitarian

\section{Fifield, Harper's Magazine, CXC, p. 191.}

5 Sibley, Conscription of Consclence, p. 85. For number who recelved pardons, see Alis on Reppy, civil Rights in the United States (New York: Central Book Co., 1951), p. 5. 
consclentious objector.

In most cases the Witnesses were imprisoned not for objection to military service, but for violation of the Selective Training and Service Act of 1940 in refusing to make themselves avaliable before boards and commissions, and refusing to obey administrative rulings. The unique feature here is that in every case of conscientious objection involving Jehovah's Witnesses, the question of administrative finality was in some way directly related. Thus on the level of administrative law, the question of judicial review of selective service boards became the leading problem. The court was compelled to find the answers to two questions; "what should the scope be of Judicial review of Board classifications?" and, "at what point in the administrative process could review take place?"6 Up until the end of hostilities, the predominant judicial opinion was that an objector could not violate a board order on a plea that the order was invalid. As this chapter will reveal, it was a series of Witnesses cases that modified this rule, but the change occurred after the war.

A second unique feature in the Jehovah's Witnesses cases was the contention of the objectors that they were all ministers (for a statutory differentiation of ministers, see table 2 in appendix). Here too, the problem of the meaning of "religion" was involved to the point that the court could have well asked,

$$
6_{\text {Ib1d.., p. } 422 .}
$$


"how could a group whose doctrines denounce religion demand ministerial exemption?" But the court made no such queries. Instead, it dealt with procedural matters rather than to involve itself in inextricable substantive abstractions. In these cases, "the constitutional issues seldom concerned religious freedom, but rather turned on questions of administrative law and procedure."7 Thus the administrative law aspect continued to dominate in these cases affecting a group whose activities were motivated by religious beliefs.

The court did not reject or ignore the question of religion, but the meaning of religion was a matter which was handled by the lower courts. The Supreme Court did not give an opinion as to what was meant by the statutory term "religious training and belief," which was the condition required for exemption. The lower courts however, did. At first, the court from the Second Circuit distinguished "political" objection from "religious" objection defining the latter as a response to an "inward mentor." 8 Then again in another case the same court upheld the claim of an objector who admitted he was an agnostic. Here the court thought it enough that the objection was not on "political" grounds, but on a "deep-rooted" aversion to war.9 In the next year, the court of the

7 Pritchett, The American Constitution, p. 474. 8United States v. Kauten, 133 F. 2d 703 (1943).

9United States ex. rel. Phillips v. Downer, $135 \mathrm{~F} \cdot 2 \mathrm{~d}$ $521(1943)$. 
265

same circuit decided that an objector who believed war was morally wrong met the "religious" test.10 still later the tribunal held that an objector who denied bellef in the deity but acknowledged a "moral force" in the universe could be looked upon as "religious," and satisfying the statutory requirement.11 Then in 1946, the court of the Ninth Circuit repudiated the doctrines so consistently enunciated theretofore by the court of the second Circuit. In the case of Berman v. United States, 12 the Court declared that a belief in the deity was essential to meet the "religious training and belief" term of the Act. It was thus the work of the appeals court that provided the construction to an important statement in an act of congress. According to this development, "religious" meant that there must be an acknowledgment of a supreme being.

The third unique feature predominant in the Jehovah's Witnesses cases was in the distinction between conscientious objection and ministerial exemption. The Witnesses made no distinction, while the statute did.

One of the most prolific sources of litigation involving classification under the Act of 1940, is the dual conscientious objector-ministerial claim

$761(1 9 4 4 \longdiv { \text { . } }$

10United States ex. rel. Brandon v. Downer, $139 \mathrm{~F} .2 \mathrm{~d}$ (1945).

IlUnited States ex. rel. Reel v. Badt, 141 F. 2d 845

$$
12 \text { I56 F. 2d } 377 \text { (1946). }
$$


266

made by members of the organization known as Jehovah!s Witnesses. The members of this group generally seek complete exemption as ministers of the gospel, claiming ordination by Jehovah, and file conscientious objector claims for ministerial exemption.13

The above quoted statement presents the problem of the dual roie piayed by the jehovan's witnesses, but it confuses the distinction between the minister and the objector as prescribed by statute. The Act exempted all ministers by virtue of the nature of their profession, but conscientious objectors were not totally exempt, they were expected to perform noncombatant or purely civilian duties. In cther words, the minister's exemption was not dependent upon his conscientious objection to national service. He could be a nonobjector and st111 be exempted from service. In this general area, the law, provided three classification: I-A-O, noncombatant military service; IV-E, civilian public service; and IV-D complete ministerial exemption. Some ministers who were conscientious objectors, who could have applied for IV-D classification; instead applied for $I-A-O$ or $I V-E$ and served in these respective areas. But the Jehovah's Witnesses presented a problem because they demanded ministerial exemption (IV-D) while all outward indications seemed to show that they were

13Joseph C. Duggan, The Legislative and Statutory Development of the Federal Concept of Conscription for Military Service (washington D.C; Catholic University of America Press, I946), pp. 146-147. 
267

conscientious objectors and not ministers. This perplexing problem only aggravated administrative difficulties.

Under ordinary circumstances it was assumed that ministers were engaged full time in their religious pursuits, but such was not true of the Jehovah's Witnesses. Most of them dependeù upon secular occupations for a livelfinood. Some of them devoted as little as six hours per week to religtous activities, and still insisted on ministerial exemption. The Court took special note of this unusual arrangement and gradually "held that the statutory definition does not preclude all secular employment, since many preachers, even in the more traditional sects may not have congregations that can pay a living wage."14 The rationale of this argument is that these ministers would be engaged in full time religious service, if the congregations to which they ministered could support them financially. The Court did not say this, but it did say several times that members of financially poor congregations should not be penalized for their low economic status. There were, of course, other criteria to determine whether a person should be granted ministerlal exemption, and these are examined in the following pages. But the important point here is that this particular constitutional problem was peculiar to the Jehovah's Witnesses.

14David Fellman, "Constitutional Law in 1953-1954," A.P.S.R., XIIV (March,1955), p. 84 . 
In all this the issue of statutory construction became the prominent theme. It was a matter of reading the law passed by the legislature so as to effect the process outlined by Congress. It was not so much the question of objection -the legislature and the court were willing to grant that -- but the issue hinged on the procedure through which the registrant could object and on what legal ground.

From the standpoint of legal status, there was no difference between the objector and nonobjector up to the point of registration. It was after registration that the legal differentiation became meaningful and statutory construction significant. In the beginning some of the Jehovah's Witnesses failed to register, but discovered soon enough that at that stage, they had no constitutional ground from which to make their attack. So the procedure they followed was to comply with all the procedural demands short of actual induction. Then they would insist on administrative review -- and exemption. It was then left with the courts to determine whether review was available, and if so, was there ground for such review -- and exemption from national service.

The first conscientious objector case involving Jehovah's Witnesses to reach the Supreme Court was Falbo v. United States 15 decided on January 3, 1944. The date is somewhat significant in that the Witnesses were always opposed to military 
service and refused to serve in the armed forces even before America was forced to enter the war in December of 1941. It seems rather unusual that the first case should be recorded more than two years after the United States became a participant in the general holocaust. Justice Black gave the majority decision and concluded his opinion by noting that this time delay was a factor contributing to the majority decision. The "petitioner 25 years of age, unmarried, and apparently in good health registered with his local board on October 16 , 1940."16 In the consideration of his claims, the local board and also the board of appeal delayed the classification pending further study. The order to report was finally issued on September 2, 1942. "Today, one year and four months after this order, he is still litigating the question."I7 To Black and the majority, Congress had more than satisfied the requirement of insuring proper procedure for hearings and appeals.

The case was tried in a federal district court of Pennsylvania after the Petitioner, Falbo, knowingly failed to report for assignment to work of national importance. The selective Training and Service Act of 1940, required service of national importance for conscientious objectors, and Falbo was classified as such after he supplied pertinent information on a prescribed questionnaire. The classification of registrants

\section{Ibid., p. 555. \\ 17 Ibid.}


270

by the board was in accordance with the standards provided in the Act and Selective Service Regulations. The petitioner admitted his wilful refusal to obey the law, but defended on the ground that he was exempt from all national service since the facts he presented the board showed clearly he was a duly "ordained" minister. The district court refused to recognize the contention because the facts presented did not indicate clearly ministerial status, and the court felt that it was the duty of the board to classify registrants regardless of how the registrants may feel. The court then instructed the jury to find the petitioner guilty if the facts showed that he failed to report. The petitioner's failure to report was substantiated and he was sentenced to five years imprisonment. The petitioner appealed the case contending the district court erred in refusing to permit a trial de novo on the merits of his own claims. What the court should have done, according to the petitioner was at least to review the judgment of the board to ascertain whether it was "prejudicial, unfair, and arbitrary"18 in its classification. The supreme Court "granted certiorari because of the important problems involved relating to administration of the Selective Training and Service Act of 1940."19 Urging a reversal, the National Committee on Conscientious Objectors of the American Clvil Liberties Union

\section{$18_{\text {Ibid., p. } 551 .}$ 19 Ibid.}


filed a brief of amicus curiae.

Mr. Justice Black made careful references to the general ourposes of the Act and the power of Congress to carry out measures relating to the overall mobilization procedure. He pointed out all of the intricacies and the numerous steps involved fin the selective process, beginning with the simple initial registration. If during the process a registrant wished to test his classification, he could appear before the board and if the board refused to alter his classification he could then take his case to the board of appeal; and beyond that, under certain circumstances, he could apeeal his case to the President. The registrant by law, was not required to report for service until he had had the opportunity to exhaust the procedure. Conscientious objectors who were opposed to noncombatant service as in the case of Falbo, were ordered to report for work of national importance. "In each case the registrant is under the same obligation to obey the order."20 Through this whole procedure there always existed the likelihood that a registrant may be rejected at the induction center or at the Civilian Public Service camp.

The connected series of steps into the national service which begins with registration with the local board does not end until the registrant is accepted by the arm, navy, or civilian public service camp. Thus a board order to report is no more than a necessary intermediate step in

$$
{ }^{20} \text { Ibid., p. } 553
$$


a united and continuous process designed to raise an army speedily and efficientiy.21

The constitutional question was narrowed by Black to whether "Congress authorized judicial review of the propriety of a board's classilication in a criminal prosecution for wilful violation of an order. ."22 He then answered the question. "we think it has not." 23 In authorizing the board to have discretion in making the classificiation, Congress was careful to prescribe a step-by-step process which it obviously did not wish to have interfered by the judicial branch. To the petitioner's argument that judicial review must be made available to test the soundness of the decision made by the board, the Court said, "It is certain that congress was not required to provide for judicial intervention before final acceptance of an individual for national service." 24 Neither legislative history nor the wording of the Act indicated any intention by Congress to provide for judicial review during the process of selection.

The circumstances under which the Act was adopted lend no support to a view which would allow LITIGIOUS INTERRUPTION of the process of selection

21 Ibid.

22 Ibid., p. 554.

23 Ibid.

${ }^{24}$ Ibid. 
which congress created. 25

Mr. Justice Rutledge wrote an opinion concurring with the majority, but made note of one additional fact. The petitioner made claim that the local board's refusal to classify Falbo as a minister was determined partialiy by the antipathy to the religious sect to which he belonged. If such a question were open -- and Rutledge intimated that evidence tending to substantiate such a claim was lacking -- the petitioner had not made the same charge against the board of appeal which reviewed the order and affirmed it. "And there is nothing to show that the appeal board acted otherwise than according to law."26 If there were defects in the original classification, they were cured by the appeal board's action. Rutledge felt, as did Black, that Congress purposely excluded judicial review of selective orders.

In accepting the Falbo case for review, the majority indicated it did so partially on the basis that the court of appeals had not expressed uniform views on the issue. It has been argued however, "the Falbo opinion confirmed and restated circuit court rulings and became the leading case on the subject down to the end of hostilities."27 Whatever the arguments involved, it is true that the Falbo decision established

$$
\begin{aligned}
& 25 \text { Ibid., Italics supplied. } \\
& 26 \text { Ibid., p. } 555 . \\
& 27 \text { Sibley, Conscription of conscience, p. } 425 \text {. }
\end{aligned}
$$


274

nothing new in the way of constitutional principles. If the case presented any novel development, it would more likely be found in the dissenting opinion of Mr. Justice Murph $\ddot{~}$

In his dissent, Murphy took an extremely libertarian view. Emphasizing the importance and need for the preservation of individual rights even in a time of war, Murphy felt that in passing the Act, it was not the intention of Congress to seek conviction without benefit of a full hearing. If, as the petitioner contended, the classification by the board was arbitrary and contrary to law, then the order issued by the board to report for work was invalid and the petitioner had grounds for refusing to obey the order. The real question to Murphy was "simply whether petitioner can introduce evidence to that effect as a defense to a criminal prosecution for failure to obey the order."28 He was especially fearful that in time of war individual liberties in the hands of those whose administrative discretion was uncontrolled, would be highly susceptible to abuse. It disturbed the Justice greatiy. that one of the local board members was alleged to have remarked, "I do not have any damned use for Jehovah's Witnesses."29 The defense as presented by the petitioners was therefore quite strong as far as Murphy was concerned. He thought neither the Selective Service Act, nor the war effort compelled the result

$$
\begin{aligned}
& 28 \text { Falbo v. United States, p. } 556 . \\
& 29 \text { Ibid., p. } 557 .
\end{aligned}
$$


275

reached by the Court. Herein was the difference between the majority opinion and the dissent; whereas the majority felt the Act excluded judicial interference with prescribed procedural measures, Murphy thought this was reading too much into the Act, for history as well as the "structure of the Act" was adverse to such unreasonable interpretation.

Murphy went along with the contention that the Act was designed to operate as a continuous process in the selection of men for national service without "litigious interruption." but here the interruption had already occurred. "We are faced here with a complete and permanent interruption springing not from any affirmative judicial intervention but from a falure to obey an order."30 At this stage, judicial review "has none of the elements of a 'Iltigious interruption' of the administrative process."3I To Murphy, it was the "continuous process" of selection that made this case unique from ordinary administrative proceedings. Rules preventing judicial review in ordinary administrative proceedings and also the requirement that all remedies must first be exhausted, did not apply here because those rules were intended to prevent unnecessary inconvenience imposed upon administrative agencies by premature judicial intervention. "But since the administrative process has already come to a final ending, the reason for applying

$$
\begin{aligned}
& 30 \text { Ibid., p. } 558 . \\
& 31_{\text {Ibid. }}
\end{aligned}
$$


such rules no longer exists. "32 Murphy thought it was unthinkable that judicial review was made unavailing in a criminal procedure involving arbitrary and invalid administrative action. Judicial review seemed even more imperative to Murphy because here, induction was not possible and therefore other remedies, such as the writ of habeas corpus, were not ava1lable.

Among other problems, Falbo left unsettled the question concerning judicial review after a petitioner had exhausted all available procedural remedies as prescribed by the law. Such a problem faced the court in the case of Estep v. United States, argued together with Smith v. UnIted States. 33

Estep, a member of the Jehovah's Witnesses was classifled by his local draft board as I-A, thereby making him readily available for military service. As a minister of the gospel Estep claimed he should have been classified IV-D under the Act which so classified "duly ordained ministers of religlon." After being overruled by the local board, the petitioner appealed his case to the appeal board which also classified him as I-A. He then asked the National Directors of Selective Service to appeal to the President. This request was refused. He was then ordered to report to the induction center, and was accepted by the Navy. The petitioner refused

32 Ibid.

33327 U.S. 114 (1946). 
to be inducted on the basis that he was a minister and therefore exempt from service in the national armed forces. He was then convicted by the district court for wilfully refusing to submit to induction. Estep's contention was twofold. First, "he had been Improperly denied exemption from service, because the classifying agencies acted arbitrarily and capriciously in refusing to classify him as IV-D."34 secondly; he claimed that certain relevant material was unlawfully witheld from the appeal board thereby denying him the right to effective appeal. The district court refused to accept these defenses and did not permit introduction of evidence claimed by the petitioner. The jury found Estep guilty and he was sentenced to a term of five.years imprisonment. The Circuit Court affirmed the judgment on appeal.

Smith, like Estep, was a Jehovah's Witness who claimed exemption from military service on the ground that he was a minister. The local board classified him as I-A which was affirmed by the board of appeal, and also affirmed by the President. He was then ordered to report to the induction center where he was accepted for military service. Smith refused to be inducted and was then forcibly inducted into the service against his will. Once in the armed forces, he refused to obey orders and was held for trial by a general court-martial. Smith's rotion for a writ of habeas corpus was denied. While 
278

the petitioner was being held by the military, the court decided on another case which determined the right of Smith's suit for a writ of habeas corpus. In Billings v. Truesdeli 35 (Not a Jehovah's Witness case), the petitioner was a conscientious objector who was forcibly inducted into the army, and against his will, the army administered the oath and other necessary ceremonials. When he disobeyed military orders he was charged and convicted for wilful disobedience. The Supreme Court held that under these conditions, the petitioner was not subject to trial by a military court, but by civil authorities. The Bilings case became controlling in Smith's defense before the court. He was thus released and indicted by the circuit court of appeals for violation of the Selective Training and Service Act.

Because of the importance of the question presented, the Supreme Court accepted and reviewed both cases on certiorari. In speaking for the majority, Mr. Justice Douglas first of all distinguished this from the Falbo case. In Falbo, the Court held that in criminal prosecution arising from a failure to report for Induction, a registrant could not defend on the ground that he was wrongfully classified and therefore entitled to exemption. In other words, judicial review was not available until all the steps of induction were completed. But,

The question in these cases is whether there may be

353.21 U.S. 542 (1944). 
279

judicial review of his classification in a prosecution under section 11 where he reported for induction, was finally accepted, but refused to submit to induction. 36

The failure of the Act to provide for judicial review of actions of local boards or appeal boards permitted the court to exercise wide discretion. Thus, in Justice Murphy's words, "Courts are left to their own devices in fashioning whatever review they deem just and necessary." 37 Citing Ng Fung Ho v. White, 38 Douglas said that judicial review may be required by the Constitution. But unless it is so required, "judicial review of administrative action may be granted or witheld as Congress chooses."39 In this case however "we start with a statute which makes no provision for judicial review of the actions of the local boards or the appeal agencies." 40 But the absence of such a provision was not enough to be decisive, said Douglas.

For the silence of Congress as to judicial review is not necessarily to be construed as a denial of the power of the federal courts to grant relief in the exercise of the general jurisdiction which

36 Estep v. United States, p. 116 . $549(1944)$.

37Dissenting Opinion, Falbo v. United States, 320 U.S.

38259 U.S. 276 (1922).

39Estep v. United States, p. 120 .

40Ib1d., p. 119 . 
Congress has conferred upon them. 41

That the statute remained silent over the matter of judicial review, according to Douglas, did not mean that judicial review was precluded. He thought the Act did limit the right of review however, for he felt that the question as to whether judicial review should be provjded when congress remained silent, would depend "on the whole setting of the particular statute and the scheme of regulation which is adopted."42 The Selective Training and Service Act also provided that decisions of the local boards shall be "final" except where appeals were authorized in accordance with rules and regulations prescribed by the President. This proyision was also a point of contention which the Court had to settle. Noting that a registrant who violated the Act committed a felony, Douglas agreed that he was subject to proper punishment, but the question of available defense was in doubt because of the statute's silence. Furthermore:

We cannot readily infer that Congress departed as far from the traditional concepts of a fair trial when it made the actions of the local boards "final" as to provide that a citizen of this country should go to jail for not obeying an unlawful order of an administrative agency. 43

$$
\begin{aligned}
& 4{ }_{\text {Ibid., p. } 120 .} \\
& 42 \text { Ibid. } \\
& 43 \text { Ibid., p. } 122 .
\end{aligned}
$$


281

To Douglas, the provision making board judgments "final" meant that Congress chose not to give administrative action under this Act the usual scope of judicial review granted to others. "It mears that the Courts are not to weigh the evidence to determine whether the classification made by the local boards was justified." 44 The decisions of the local boards therefore would be final even when they are erroneous. But the question arises -- as in this case -- "when there is no basis in fact for the classification which it gave the registrant." 45 congress, had it been aware of some of the problems that would arise, certainly would not have left the remedies for individual protection deliberately out of reach.

We are loathe to believe that Congress reduced criminal trials under the Act to proceedings so barren of the customary safeguards which the law had designed for the protection of the accused. 46

In the Falbo case, Mr. Justice Murphy's dissent mentioned that habeas corpus was a remedy but was not available until a person was inducted and held in custody. In the instant case, similarly, Douglas was greatly concerned over habeas corpus proceedings. If the court were to deny the petitioner his right to defend on the ground that the local board acted

$$
\begin{aligned}
& { }^{44} \text { Ibid. } \\
& { }^{45} \text { Ibid., pp. 122-123. } \\
& 46_{\text {Ibid., p. } 122 .}
\end{aligned}
$$


arbitrarily, then his only defense against the board's arbitrary action would be through a writ of habeas corpus after he had been taken into custody. "The court would then be sending men to jail today when it was apparent that they would have to be released tomorrow." 47 under the Selective Draft Act of 1918, the accepted way of challengling the furfsdiction of draft hoards was through a writ of habeas corpus after induction. The 1917 Act also made the registrant subject to military law from the time he was ordered to present himself for induction. A refusal was held to constitute desertion from the military. But Billings v. Truesdell, supra, changed the whole process. It made the registrant subject to military law only after he had been properly inducted.

Douglas admitted that in the Falbo case the petitioner was denied his petition for a habeas corpus, but in that case "additional steps in the selective service procedure remained to be taken. . . . But in the present cases the registrants... pursued their administrative remedies to the end." 48

Thus the court ordered a new trial on the ground that the lower court erred in refusing to admit evidence which the petitioners claimed would show that the local board acted arbitrarily in classifying the registrants $1-A$ instead of IV-D. There were three written opinions concurring with the

$$
\begin{aligned}
& 47 \text { Ibid., pp. 124-125. } \\
& 48 \text { Ibid., pp. 124-125, n. } 17 .
\end{aligned}
$$


283

majority. Mr. Justice Jackson took no part in the case. Mr. Justice Murphy, who wrote a strong dissenting opinion in Falbo, again took the banner for the cause of the conscientious objectors. To affirm the lower court judgment he said, was to "condemn a man without a full hearing and a consideration of all of his alleged defenses." 49

Murphy's concurring opinion began by refuting three contentions raised by the prosecution. First, Congress designed the Act to preclude courts from inquiring into the validity of the induction process. If this were true, said Murphy, the Act itself is unconstitutional.

\begin{abstract}
Before a person may be punished for violating an administrative order due process of law requires that the order be within the authority of the administrative agency and that it not be issued in such a way as to deprive the person of his constitutional rights.50
\end{abstract}

And the Court which has the jurisdiction to try such a case had the clear right to inquire into the matter in order to preserve the individual's constitutional rights. Because the Act remains silent regarding certain matters was no reason to construe the Act in such a way as to reach an unconstitutional result. Here, Murphy made reference also to the provision of the Act which made local board decisions "final." This, he thought, "merely determines the point of administrative finality,

$$
\begin{aligned}
& \text { 49Ib1d., p. 125. } \\
& \text { 50Ib1d., pp. 126-127. }
\end{aligned}
$$


284

leaving to the courts the ultimate historical duty of judging the validity of the 'final' administrative orders. . "5l Second, the purpose and scheme of the legislation which made provisions for full hearings, were conditioned by the urgent need for mobilization and in view of the dire consequences of undue delay. Thus no "litigious interruption" could be tolerated. At this point Murphy cited his dissenting opinion in the Falbo case in which he stated that the interruption had already occurres. The courts there faced a real situation, not a theory. The prosecution also urgued that to allow a full hearing in a criminal proceeding under this Act, would permit a whole host of similar cases arising from the refusal to be inducted by other registrants. To this Murphy replied, "This is at best a poor excuse for stripping petitioners of their rights to due process of law."52 In reality, the number of those who would go through the trouble of submitting their case before the courts and risk criminal punishment would be very small. On the part of the Justice, this was a poor constitutional argument, for he was saying, in essence, the validity of the Act was dependent upon the amount of cases the decision would provoke. He went on to say however, that if the adherence to due process of law should "Impede the war effort unduly,.. . there are undoubtedly legislative means of combating the problem." 53 Third, judicial

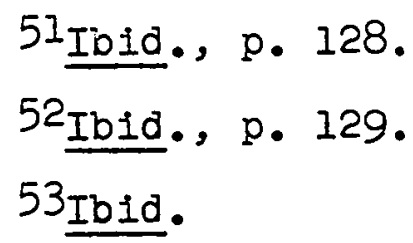


285

review of induction orders was available through habeas corpus proceedings subsequent to induction. This, the contenders claimed met the constitutional requirement of providing for judicial review. To this contention Murphy agreed, but he was worried that the "remedy may be quite illusory in many instances." 54 once the person was inducted into the military service he dropped every vestige of civil rights."55 Murphy well understood that court trials in the military did not have a reputation for "fair play" and the outlook for a quest of a writ of habeas corpus under those sonditions would certainly be bleak. The detainment in military cases, often occasioned by great distances and the constant shift of personnel did not offer any assurance that the military would "treat his efforts to obtain the writ with sympathetic understanding." 56 Murphy seemed to be greatly concerned over the difference between the military and the civil systems. The former he felt, of necessity, could not afford sympathy or even extend the benefit of the doubt to individuals as was expected in civil proceedings.

These practical difficulties may thus destroy whatever efficacy the remedy might otherwise have and cast considerable doubt on the assumption that habeas corpus proceedings necessarily guarantee due

54 Ibid. In comparison with the majority opinion, Murphy in this instance went to the extreme. See Sibley and Jacob, Conscription of Conscience, pp. 426-427.

55 Ib1d.

$56_{\text {Ibid.., p. } 130 .}$ 
286
process of law to inductees. 57

To Mr. Justice Murphy the sole question was "whether due process of law is to be granted now or never. The choice," he said, "seems obvious."58 If Murphy took a libertarian view In the Falbo case, he seems to have pursued that view more vigorously in the instant case. He concluded his opinion in the usual manner by denouncing unfavorable practices and extolling the virtues of broad constitutional principles.

There is something basically wrong and unjust about a juridical system that sanctions imprisonment of a man without ever according him the opportunity to claim that the charge made against him is 1llegal. . . Every fibre of the constitution and every legal principle of Justice and fairness indicate otherwise. . . Those rudimentary concepts are ingrained in our legal framework and stand ready for use whenever life or liberty is in peril. 59

He then offered a warning by the reminder that the legislation in question was "born of the cataclysm of war." 60 And that the war power was not a blank check to be used to disregard basic individual rights. Indeed, the whole war effort would have been in vain if we discover in the end that "we have destroyed the very freedoms for which we fought." 61

57 Ibid.

58 Ibid., p. 13 .

59 Ibid.

${ }^{60}$ Ibid., p. 132.

${ }^{6} 1_{\text {Ibid. }}$ 
287
$M r$. Justice Rutledge's concurring opinion presented one other argument. He thought that a judgment contrary to that of the majority would invalidate the statute. He harbored no doubt that congress could make an auministrative order final and exclude all judicial review, except in cases where the Constitution required a review, but congress could not make a crime punishable by federal judicial power without requiring adequate opportunity to test the constitutionality of the order.

It is one thing to deny jurisdiction of the courts altogether, save in so far as the Constitution of its own force may preserve the jurisdiction. It is altogether different to confer jurisdiction for enforcement purposes, but in doing so to cut off all right of defense on constitutional grounds. 62

Then Rutledge borrowed Douglas' phrase and said, to submit to the lower court's view would make the courts march "up the hill in the criminal case and down again in habeas corpus." 63 Mr. Justice Frankfurter also registered a concurring opinion with the majority, but spent most of the time attacking the court for its reasoning. He concurred with the result only because he felt that "appeals from the local board had been denied to Estep."64 To Frankfurter, there were two constitutional

\section{Ibid., p. 133.}

63Ibid. Douglas had remarked in the majority opinion that the courts would have to "march up the hill when it was apparent that they will have to march down again." p. 125. ${ }^{64}$ Sibley, Conscription of Conscience p. 427. 


\section{8}

questions the import of which compelled him to "call for an adequate statement. .."

I. Is the decision of a local board denying a claim of exemption subject to reconsideration in a criminal prosecution for knowingly failing to discharge the duties required by the Act as a result of such classification?

II. Is action by the local board whereby a registrant is cut off from the opportunities of a review within the Selective Service process as authorized by the Act available as a defense in such prosecution for disobedience of the local board's order?65

Frankfurter felt that the crucial issue which touched the "nervecenter" of the Act was whether congress authorized the Selective Service System with the responsibliity of selections, deferments, etc., or left that determination for reconsideration in trials before juries. The Justice was chiefly concerned over section 10 of the Act.

Surely local boards, under rules and regulations prescribed by the President, shall have power within their respective jurisdictions to hear and determine, subject to the right of appeal to the appeal boards here in authorized all questions or claims. - . under this Act... . The decisions of such local boards shall be final except where an appeal is autroorized in accordance with such rules and regulations as the President may prescribe. 66

There was nothing ambiguous about these words or their meaning

$65_{\text {Estep }}$ v. United States, p. 135.

6654 stat. $885,893,50$ U.S.C. App. Section 310 (a) (2). Quoted in full in Ibid., p. 136 . 
289

as far as Frankfurter was concerned. "These words," he said, "can only mean what they appear to mean if they are read as ordinary words should be read."67 He was especially irritated by the Court's interpretation of "final." "One need not italicize 'final' to make final mean final,"68 he scolded. Congress knew what it was doing and intended to give finality to board orders. Congress also realized that because of a national emergency, Congress deemed it imperative to secure a vast citizen army with expedition and dispatch. Thus he said, "we must. - .resist unwarranted implications to sterilize what Congress has expressly required." 69

Frankfurter then made a strong case for precedent and the effects of the Falbo decision in subsequent cases. He pointed out that at least forty judges in eight different circuits had ruled that judicial review was not available under such conditions. $7^{0}$ So great was the Court's reasoning in Falbo:

that it greatly influenced the ruling of the Circuit Courts of appeals as to the finality of local board orders and practically silenced whatever doubts may theretofore have been held by a few of the judges.71

67Estep v. United States, p. 136.

68 Ibia.

69 Ibid., p. 137.

70 Frankfurter here cited and listed at least twentyeight cases decided upon by the various circuit courts. Ibid., p. 139.

7 I Ibid. 
On this issue the majority had argued that the Falbo case denied judicial review at a certain stage of the selective process, not to deny the review altogether. To Frankfurter, this made no difference, "The command of Congress," he said, "makes the decision of the board no less final after the resgistrant has submitted to the pre-induction examination than before such submission." 72

Frankfurter's argument was given strength by the report of the House Committee on Military Affairs, the originator of the Act, when in 1945 it proposed an amendment to the Act which read in part:

In order to obtain a judicial determination of such issues such registrants must first submit to induction and raise the issue by habeas corpus.73

It was evident to Frankfurter that "Congress wanted men to get into the army, not to litigate about getting in." 74 The legislation was passed on the assumption that the carefully devised scheme of the selective system would too seldom go awry to justify review by the courts. Besides, in those negligible number of cases in which registrants felt that their induction was too hasty, or groundless, their submittance to

\section{Ib1d., p. 138.}

73H.R. Rep. No. 36, 79th Congress, First Session (1945), pp. 4-5. Quoted in Ibid., p. 140.

74 Estep v. United States, p. 140. 
291

induction would make them available while they were in the army, not while serving prison terms for disobedience. "Accordingly, Congress legislated to discourage obstruction and delay through dilatory court proceedings that would have been inevitable if judicial review of classification had been afforded during the war years."75 The clarity of the language in the Act and the authority of Congress over such matters were clear evidence to Frankfurter that more than ever the Court should have exercised fudicial restraint. These considerations should have been given greater welght by the Court in view of the prevailing conditions which motivated Congress to pass the Act. To allow judicial review in this instance would "disrupt a whole scheme of legislation under which millions of orders need promptly to be made and promptly to be respected and were therefore endowed with finality when sanctions for disobedience are sought." 76

After saying all this, Frankfurter quickly gave his reason for concurring with the majority. Estep, he felt, was denied the right to make proof of his claim that the local board frustrated his right to have his case reviewed properly by the appeal board. He made it clear that Estep had a duty to obey an order of the draft board even after the order was no longer subject to review by the Selective Service system. But in

$$
\begin{aligned}
& 75 \text { Ibid., pp. 140-141. } \\
& 76 \text { Ibid., p. } 142 .
\end{aligned}
$$


this case, the board violated the Act by denying the petitioner the right to prove that his appeal process was unduly hindered. In the case of Smith, Frankfurter felt that there was basis in the petitioner's contention that he was tried and convicted for failing to show up for induction. Although in his case, he was forcibly inducted, he did present himself at the induction center for examination. To the Justice, "the trial court's charge is at best ambiguous. "77 Thus he felt that the petitioner "labored under the handicap of a trial Court's ambiguous charge to the jury."78 Quoting from Bollenbach v. United States, 79 Frankfurter said, "A conviction ought not to rest on an equivocal direction to the jury on a basic issue." 180 On this ground the conviction was properly reversed, but Frankfurter clearly indicated that he did not go along with the majority reasoing.

Mr. Justice Burton, with Mr. Chief Justice Stone concurring, recorded a short dissenting opinion. There was no need, said Burton, to elaborate on the reasons for their dissent, because Justice Frankfurter did that for them. They did not of course agree with Frankfurter that the petitioners were frustrated by the boards in their attempts to show that the

77 Ibid., p. 145.

78 Sibley, conscription of Conscience, p. 427.

$79_{326}$ U.S. 607 (1946).

80 Estep v. United States, p. 145. 
293

local board or the trial court had erred. Their basic contention was that registrants could seek rellef only after they obey the orders and submit to induction. Then the proper relief would be through a writ of habeas corpus.

The case of Gibson v. United States, argued and decided together with Dodez v. United States, 81 was taken on certiorari from the Court of Appeals. Both Gibson and Dodez, Jehovah's Witnesses, were aware of the Falbo difficulty and did everything they could to be sure that the administrative process had been fulfilled before making their move in the judicial arena. Both cases were identical in the following respects. Each was denied the ministerial classification, IV-D, instead was classified as conscientious objectors, IV-E, They both exhausted administrative appeals, and upon doing so, were assigned to work of national importance in their respective camps. At this stage, the two cases differed. Dodez refused to go to the camp as ordered. Gibson, on the other hand, thinking that the Falbo decision required him to report first, in order to exhaust the final step of the administrative process, went to camp, stayed there five days, and then departed without leave.

These cases were not only unique, but somewhat complicated

${ }^{81} 329$ U.S. 338 (1946). For a brief discussion on the treatment of conscientious objectors under the Act of 1940 , see John W. Masland et. al. "Treatment of the Conscientious Objector Under the SeTective Service Act of 1940, A.P.S.R. XXXVI, 4 (August, 1942), pp. 697-701. 


\begin{abstract}
294
because one went too far in his attempt to exhaust the administrative process while the other did not go for enough, and yet each was no more than one step apart from the other. As it was stated by Mr. Justice Rutledge, who gave the majority opinion:
\end{abstract}

Clearly, on the facts and the issues, the question as to Dodez, like that in Falbo's case, is whether he went far enough to axhaust the administrative process; which as to Gibson it is said that he went too far, that is, beyond the point of completing that process, and that this cut off the right of defense concedediy available to him at that point. 82

These cases were further complicated by the change of regulations effective only a few weeks after Falbo. One of the major changes in regulations required the physical examination to be given before the registrant was ordered to report for induction. When Dodez was ordered to report to camp, this regulation was applicable so that once he reported to camp there was no possibility of being rejected there on the basis of a physical examination. Too, had Dodez reported to camp, then tried to make a defense, under the contention of the respondents in Gibson he would have gone too far. The court said:

We hold therefore, in accordance with Dodez' view. . that he was not required to report to camp, under the regulations effective when his order to report became operative, in order to complete the administrative process. 83

$$
\begin{aligned}
& 82_{\text {Ibid., p. } 343 .} \\
& 83_{\text {Ibid., p. } 350 .}
\end{aligned}
$$


Falbo was therefore distinguished and declared to be not controlling in the case of Dodez. He was therefore not required to report to camp in order to complete the administrative process and was not foreclosed from making a defense that his classification was invalid.

The Gibson case presented a somewhat different problem because there, Gibson had been "inducted" into service. This action, the Government contended was analogous to being inducted into the army. Because he went beyond the point from which he could defend against the charge of desertion, Gibson's only remedy was through a writ of habeas corpus. The court admitted that "Gibson's departure without leave amounted to desertion," 84 and his defense of wrongful classification would not be open under these condtions; but on the other hand, the Government's analogy was weak:

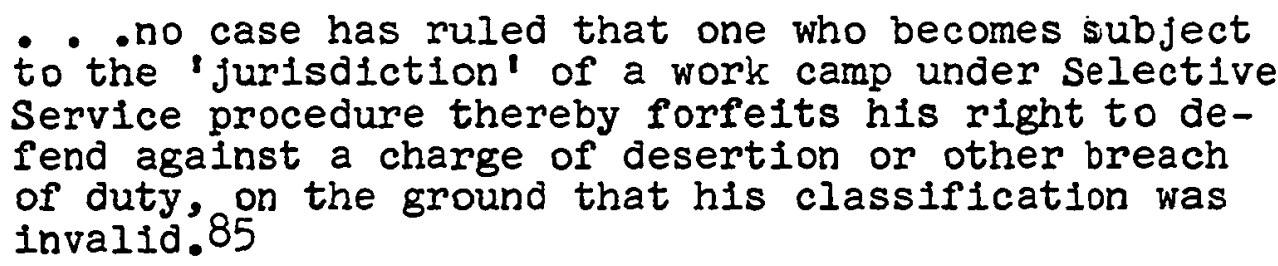

The court argued that unlike the ordinary inductee, the person classified IV-E remains a clvilian. There is in fact no substantial change in "jurisdiction" after he is inducted

$$
\begin{aligned}
& { }^{84} \text { Ibid., p. } 353 . \\
& 85 \text { Ibid., p. } 356 .
\end{aligned}
$$


into the camp. The orders came through the same civil channels. The person who serves in a Public Service Camp is not subject to military discipline, and he cannot be tried by courts martial. On the contrary, the selective service Act provides for civil penalties imposed by the same process accorded him before being inducted. According to the court, the Government's whole analogy was found wanting because, a person who was inducted in the military suffered a forfeiture of civil rights, whereas in the case of those in Public Service Camps, the same was not true.

To the argument that a habeas corpus defense was available as the proper remedy, Rutledge countered by pointing out that neither the camp director nor other Selective Service officials were authorized to arrest or restrain those who refused to stay in camp; therefore, it "would make doubtful the availability of relief by way of habeas corpus. "86 The habeas corpus remedy being at best uncertain, the court reasoned:

Should it be found unavailable and at the same time we should rule that petitioner's defense could not be made in the criminal proceeding, he would be left entirely without remedy, a result consistent neither with our decision in the cases of Estep and Smith, supra, nor with the statute.87

The Government and the Court both agreed that. Congress

$$
\begin{aligned}
& 86 \text { Ib1d., p. } 360 . \\
& 87 \text { Ibid. }
\end{aligned}
$$




\section{7}

intended some remedy to be available. Therefore, said Rutledge, "We know of no way by which this can be assured, in such a case as Gibson's otherwise than by permitting the defense to be raised in the criminal trial." 88

The Gibson case differed from Dodez in one other respect. Whereas Dodez was subject to the mule that a physical examination would be taken before reporting to camp, the regulation applicable to Gibson provided for a physical examination at the camp. But the regulation required the camp director to accept the registrant irrespective of the determination made as the result of the examination. Thus Gibson went all the way to exhaust administrative process, but by doing so, there was no way for him to be rejected on the basis of the physical examination, and furthermore, he was devold of a valid defense.

In both cases the appellants petitioned the Court to render a verdict of acquittal on the merits of the case. But the court refused to express any opinions on these issues and remanded the cases back to the trial courts for new trials. The decision of the supreme Court was unanimous.

Still another case came before the Supreme court in 1947 which was further complicated by the decisions of Falbo and especially Estep. The case of Sunal v. Large, Superintendent, Federal Prison Camp, together with Alexander, Warden, v.

${ }^{88_{\text {Ibid., p. }} 361 .}$ 
United States ex. rel. Kulick Sas $^{8}$ waken on writ of certiorari from the circult court of appeals.

Both Sunal and Kulick, Jehovah's Witnesses, claimed exemption from military duty on the ground that they were ordained ministers. After proper proceedings, the local boards denfed petitioners' claims and classfifled them I-A. The petitioners then exhausted the administrative process in an attempt to effect a change in their status. Their contentions were denied all the way, and finally in the Fall of 1944, they were both ordered to report for induction. Each reported but refused to be inducted, thereupon each was indicted and convicted of violation of the Act. Both were sentenced to prison for a term of years. Sunal was sentenced on March 22, 1945, and Kulick on May 7, 1945.

During the trial each of the petitioners offered evidence to show that their classirication was invalid. The courts refused to admit the evidence on the ground that the board's decisions were final and not open to attack in a criminal trial. While the petitioners were serving their prison terms, the Court decided on the Estep case 90 which made available a defense to those who challenged the validity of selective service classification after administrative process had been

89332 U.S. 174 (1947). Hereafter cited as Sunal v. Large and Alexander v. Kulick.

90The date of Estep was February 4, 1946, a little less than a year after sunal and Kulick. 
exhausted. The Estep case made it "plain, therefore, that the trial courts erred in denying Sunal and Kulick the defense which they tendered."91

Immediately after the Estep decision was given, petitions for writs of habeas corpus were filed on behalf of sunal and Kulick. In each case, the lower courts held that habeas corpus was an available remedy. In the sunal case the circuit court of appeals held that there was a basis in fact for the classification and affirmed a judgment discharging the writ. In the Kulick case the circuit court of appeals reversed a district court judgment holding that there was evidence to support the classification. Since Kulick was deprived of the defense he should have had, the circuit court of appeals ordered his discharge.

In speaking for a six to three court, Justice Douglas pointed out first of all; "The normal and customary method of correcting errors of the trial is by appeal."92 The appeals could have been taken, for there were no barriers, but the petitioners did not do so. The contention however, was that the fallure to take appeals was excusable because the lower courts had consistently ruled that selective service classification could not be attacked in criminal trial. The petitioners also pointed out that the Supreme Coust

9lsunal v. Large, p. 176. 92 Ibid., p.177. 
300

in April of 1945, refused certiorari in a similar case;93 and by the time the Estep decision was rendered, the time for appeal had lapsed. The core of the argument was "that since the state of the law made the appeals seem futile, it would be unfair to those registrants to conclude them by their failure to appeal."94 To this Douglas answered:

of course, if Sunal and Kulick had pursued the appellate course and failed, their cases would be quite different. But since they chose not to pursue the remedy which they had, we do not think they should now be allowed to justify their failure by saying they deemed any appeal futile.95

Regarding the writ of habeas corpus as a remedy for convictions obtained in federal courts, Douglas said, other than under exceptional circumstances, it "will not be allowed to do service for an appeal. "96 Habeas corpus, he said was increasingly denied in cases where error was committed, especially if "appellate procedure was available for correction of the error."97 Habeas corpus was "sometimes granted," he said,

93The reference here, according to Douglas was to Rinko v. United States, 325 U.S. 851 (1945). Certiorari was also denled In Flakowicz v. United States, 325 U.S. 851 (1945) at the same time. These cases, sald Douglas, were like Falbo in that "the administrative remedies had not been exhausted, there being an additional examination which the registrant/s] had not taken." Ibid., p. $178 \mathrm{~N} .4$.

$$
\begin{aligned}
& 94 \text { Ibid. } \\
& \text { 95 Ibid., p. } 181 . \\
& 96 \text { Ibid., p. } 178 . \\
& 97 \text { Ibid., p. } 179 .
\end{aligned}
$$


301

"where error was flagrant and there was no other remedy available for its correction." 98

Douglas carefully reasoned that after a trial came to an end it was not uncommon that a shift in law or the impact of a new decision gave new meaning to a case.

If in such circumstances habeas corpus could be used to correct the error, the writ would become a delayed motion for a new trial, renewed from time to time as the legal climate changed.99

If defendants can later renew an attack by habeas corpus after accepting a judgment of conviction, "litigation in these criminal cases will be interminable,"100 sald Douglas. Because "every error is potentially reversible error."I0I

The registrants in these cases had available a method to defend their rights, and they did not use it, "And since we find no exceptional circumstances which excuse their failure, habeas corpus may not now be used as a substitute,"102 said the Court. Sunal was thus affirmed, and Kulick reversed, accordingly. Mr. Justice Burton concurred in the result. Mr. Justice Frankfurter's dissent was more of a

98 Ibid.

99Ibid., p. 182.

100Ibid.

${ }^{10 I_{\text {Ibid. }}}$

${ }^{102}$ Ib1d., p. 1884. 
302

description of a "sloppy" system of law rather than a record of the reasons for his dissent. Said the Justice,

I think it is fair to say that the scope of habeas corpus in the federal courts is an untidy area of our law that calls for much more systematic consideration than it has thus far received.103

He admitted that it was a well-worn formula that habeas corpus cannot be made a substitute for an appeal. It was available however, in cutting "through forms and going 'to the very tissue of the structure.'" In the instant case, apparently to Frankfurter, the court was not aware of the "tissue of the structure. "I04 In determining what is the "form" and what is the "tissue" the court itself through the years "gives dubious and confused answers."I05 Then the Justice elaborated on all of the unsystematic and confused areas wherein there appeared not a thread of any legal organization on which the instant decision could find reasonable basis. As usual, numerous cases were cited to support his statements that there existed much confusion. Frankfurter suggested that perhaps habeas corpus should be left in an "unsystematized condition" in order that such flexibility could be utilized to furnish "a swift and imperative remedy," then, he said, "I believe it is true of

$$
\begin{aligned}
& 103 \text { Ibid. } \\
& 104 \text { Ibid. } \\
& 105 \text { Ibid. }
\end{aligned}
$$


303

both cases what Judge Learned Hand said of the Kulick case, that the writ is necessary 'to prevent a complete miscarriage of justice." 106 Frankfurter thus agreed with the circuit courts of appeal in declaring that habeas corpus was available as a remedy under the existing conditions.

Mr. Justice Rutledge also recorded a dissenting opinion concurring substantially with Mr. Justice Frankfurter's opin1on. He modified Frankfurter's "tentatively expressed conclusion" by making it more definite. The "great writ of habeas corpus," he said, "should not be confined by rigidities characterizing ordinary jurisdictional doctrines."107 Rutledge too made a strong case for making habeas corpus available in order to prevent miscarriage of justice. In this connection he felt that the writ should be made available whenever there occurred a "miscarriage of justice for which no other remedy is PRESENTLY possible."108 He differed greatly with the Court in that the majority did not consider it important that the petitioners had no PRESENT remedy. Confusion he said there was in quantity, but this was because if the writ were to be pinned down to "special all-inclusive categories," it would be diluted and destroyed.109 Here too, was a problem of

$$
\begin{aligned}
& { }^{106} 6_{\text {Ibid.. }} \text { p. } 187 . \\
& 107 \text { Ibid., pp. } 187-188 . \\
& 108_{\text {Ibid. }}, \text { p. } 189 . \\
& 109 \text { Ibid., p. } 188 .
\end{aligned}
$$


balance.

Admirable as may be the effort toward system, this last resort for human liberty cannot yleld when the choice is between tolerating its wrongful deprivation and maintaining the systematist's art.110

Rutledge made acknowledgment to the old rule that the writ of habeas corpus was not a substitute for appeal, but the rule itself if taken literally was contradictory. "[It] is thus in conflict with every case where the ground upon which the writ has been allowed either was or might have been asserted on appeal."Ill Rutledge was willing to accept the petitioners' condition that Falbo and other court decisions "cut off all right to make such defenses as sunal and Kulick tendered."Il2 To him this was a good reason for making available habeas corpus as a remedy, otherwise it "seems to me to prescribe a system of forfeitures in the last area where such a system should prevail."II3

Concurring with the dissenting opinions of Justices Frankfurter and Rutledge, Mr. Justice Murphy added that "today's decision unduly narrows the point at which due process may be accorded those accused or convicted of violating

110 Ibid., pp. 188-189.

${ }^{11}$ Ibid., p. 189 .

112 Ibid., p. 191.

II3Ibid., p. 190. 
the. . Act."

The conviction of three Jehovah's Witnesses, Cox, Thompson, and Roisum, for violation of the Selective TrainIng and Service Act of 1940, brought before the court yet another case involving the right of conscientious objectors to challenge the decision of draft boards in criminal prosecutions. The case of cox $\mathrm{v}$. United states was heard and decided together with Thompson v. United States, and Roisum v. United States. 114 The Supreme Court granted certiorari after the petitioners' convictions by a district court were upheld by the circuit court of appeals. Justice Reed delivered the majority opinion concurred in by Chief Justice Vinson, Justices Jackson and Burton.

Reed began by giving a brief background of each of the petitioners. Cox was registered in October of 1940. At that time the local board classified him as 4-F, not physically fit for service. On March of 1942, his classification was changed to 1-A. Ten days later Cox filed a request for reclassification of IV-E (consclentious objector), on the ground that he became a Jehovah's witness in January of 1942. After rejecting his claim, the board later reconsidered and in June 1942, granted the request. Ten days later he requested total exemption stating that he was a minister and entitled to a classification of IV-D. The local board refused to comply with 
the request, and the board of appeal sustained the decision. Cox was then ordered to report to camp on May 18, 1944. He reported on May 26 and then left camp immediately never to return.

At the trial Cox's selective service file was used as evidence. The records showed that he was "ordained" by the Watchtower Bible and Tract Society and performed the various duties including house to house visits and conducting "Bible studies." His "Pioneer service" enabled him to spend 150 hours per month to ministerial duties without secular work. Cox was a truck driver by occupation. The file showed no record of secular activities or the time spent for them. In the trial Court acting under the Falbo rule the trial judge did not examine the file to determine whether the action of the local board was arbitrary. At that time, Falbo was interpreted to mean no judicial review was available under the conditions. In view of the Estep decision, the Circuit Court of Appeals accordingly reviewed the files and "found that the evidence was 'substantially in support' of the classification found by the board."II5 Petitioner Thompson also registered in October of 1940. He immediately claimed ministerial exemption although his secular occupation was as a grocery store operator. The local board classified him as a conscientious objector, IV-E. Thompson appealed to the board of appeal stating that he was 
307

a duly ordained minister, and presented records and affidavits to that effect. The evidence indicated that in twelve months he had devoted over 500 hours of "field service," and spent time conducting studies in the local "Kingdom Hall." He was also an instructor in a "Course in Theocratic Ministry." In distinction to the other twe petitioners, "Thompson did not introduce an ordination certification from national headquarters stating that he devoted his entire time as a minister."116 There was no evidence to the effect that Thompson's activity as a grocery operator had changed. The board of appeal sustained the decision of the local board, and he was then ordered by the board to report for duty on April 18, 1944. He reported and left immediateiy.

Petitioner Roisum registered on the same date. He too filed a questionnaire stating that he was a duly ordained minister as of June 1940. Together with his request for complete exemption an affidavit was submitted by his father stating that he was needed to maintain the father's farm. His file too contained the usual information and certification stating that he was engaged in "Kingdom service," devoting his entire time to the task. The local board classified Roisum as a conscientious objector to combat service $(I-A-O)$. Roisum appealed his case to the board of appeal in June 1943. Although the appeal board rejected the petitioner's appeal to be taken to

$$
116_{\text {Ibid., p. } 446 .}
$$


the President, it reclassified him to IV-E. Roisum was then ordered to report to camp. He refused, and was arrested and indicted. "The trial Court declared a mistrial on Roisum's undertaking to obey the board's order and seek release on habeas corpus."Il7 Rolsum failed to comply, but reported to camp on May 23, 1944. He stayed in camp five days, left on a weekend pass and never returned.

All three petitioners exhausted their remedies in the selective service process and complied with the order of the local board directing them to report to camp. 118

At the trials the petitioners requested the Court to charge the jury to aquit them because the board's orders were invalid. The trial judge did not grant these requests and instead "Instructed the juries that they were not to concern themselves with the validity of the classification orders."II9 Petitioners were convicted and the circuit court of appeal, affirmed their convictions on appeal.

It was the opinion of the court that the petitioners were entitled to raise the question of the validity of their classification in the proceedings. In other words, in a criminal case of absence without leave, the question of the

$$
\begin{aligned}
& 117 \text { Ib1d., pp. } 447-448 . \\
& 118_{\text {Ib1d. }}, p_{.} 443 . \\
& 119_{\text {Ib1d. }}
\end{aligned}
$$




\section{9}

validity of selective service classification can be raised as a defense. Relying on Gibson v. United States, supra, the Court said however, the scope of review was limited. The Estep rule made it clear that Congress chose not to give the customary scope of judicial review in the administrative action of local selective service boards. This was what congress meant in making board decisions "final." Courts did not have the power to weigh evidence to determine the validity of classifications; not even when they were erroneous. 120

Mr. Justice Reed pointed out that the Selective Training and Service Act, (Section 5) made special provisions for "duly ordained ministers" to be exempt from service. In order that the local boards may be alded in their determinations, the Act was amended on November 2, 1942, "which described the tests to be applied in determining whether Jehovah's Witnesses were entitled to exemption as ministers, regular or ordained."121 The provision of the Act specified that Jehovah's Witnesses who were full time workers and were members of the Bethel Family, 122 were generally classified as duly ordained ministers making them eligible for complete exemption. The Act

$$
\begin{aligned}
& \text { 120 Ibid., p. } 448 . \text { See also Estep v. United States, p. } 122 . \\
& 121 \text { Ibid., p. } 460 \text {. }
\end{aligned}
$$

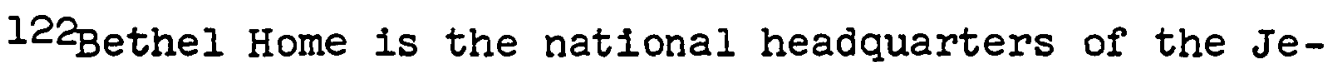
hovah's Witnesses. Under a communal system the full time workers of the Sect live and work together in this unique arrangement. For further description see Chapter $I$, especially pp. 19-20. 
310

also provided a list of Bethel Family members. 123 The petitioners' names were not on the list. Accordingly, the board's action was determined by the facts of the case, and whether petitioners were duly ordained ministers entitled to full exemption from service was for the board to decide -- its decision being final.

Our examination of the facts, as stated herein in each case, convinces us that the board had adequate basis to deny to Cox, Thompson and Roisum classification as ministers, regular or ordained.124

If the district court had committed an error in failing to examine the files of the board as contended by Cox and Thompson, Reed felt that the error was corrected by the court of appeals by that court's examination. The petitioners also requested the court to charge the jury to determine "whether they were ministers or not without considering the action of the local board."125 To this the court answered, "Whether there was 'no basis in fact' for the classification is not a question to be

123unlike other religious groups, the determination of the status of Jehovah's Witnesses has been extremely difficult. They claim not to be pacifists. They are all "soldiers" and belong to an army. The enemy they fight of course is Satan and his band. According to their own statement of bellefs, to serve in any national military program would constitute desertion from the army which they are committed to serve. For a statement of their principles, see statements of Religious Bodies on the Conscientious objector, National Service Board For ReIigious objectors. (Washington D.C., 1957), pp. 31-33.

124 Cox v. United States, p. 451.

125 Ibid., p. 452 . 
311

determined by the jury on an independent consideration of the evidence."126 Reed then referred to an administrative ruling:

The concept of a jury passing independently on an issue previously determined by an administrative body or reviewing the action of an administrative practice; the constitutional right to jury trial does not include the right to have a jury pass on the validity of an administrative order."I27?

The order of a selective service board is reviewable "only if there is no basis in fact for the classification," 128 said Reed. This of course meant that neither the preponderance of evidence for a new trial, nor the assumption that the court or a jury would reach a different verdict upon examination of the evidence, was sufficient cause for review.

Perceiving "no error to petitioners' prejudice in the records,"129 the court affirmed the judgment of the lower courts. Mr. Justice Frankfurter concurred in the result. Mr. Justice Douglas, with Black concurring, dissented on the ground that the intent of congress was to make all ministers exempt from service. He acknowledged agreement with the majority on the administrative rulings, viz., judgments of local boards cannot be reversed unless there was no basis in fact

126 Ib1d., pp. $452-453$.

127Ibid., p. 453. Reed's argument here was based upon Yakus v. United States, 321 U.S. 414 (1944).

${ }^{128}$ Ibid.

129 Ibid., p. 455. 
for the classification. "But I do not agree," said Douglas, "that the local boards had adequate basis to deny petitioners the classification of ministers." 130 Douglas refused to go along with the majority in differentiating "regular" from "ordained" ministers. This he felt was to differentiate ministers of the more orthodox faiths from the less conventional. It made no difference either that the petitioners devoted full time to ministerial work or that they were engaged in secular activities "It is not uncommon for ordained ministers of more crthodox religions to work a full day in secular occupations, especially in rural communities."131 To Douglas, unquestionably, the selective service files of the petitioners established their status as ministers. Referring to Murdock v. Pennsylvania, supra, Douglas thought that if the door-to-door practice of this minority sect can be considered as a religious practice in the same manner as preaching and worshipping in churches, then the exemptions from military service should apply equally in all cases.

Douglas's opinion seems to be important in this respect. If the Court had been dealing with purely administrative matters in all the cases thus far, for the first time, there appeared a plea smacking of religious freedom. There was also the element of equal protection as well as a federal issue

\footnotetext{
130 Ibid.

131 Ibid., pp.456-457.
} 
313

although the argument was not based on it. The essence of the dissent was not over the right of review, but the discrimination of a group whose bid for exemption from military service was made difficult by the fact that their religious practice, of necessity, often required secular activity.

A dissenting opinion in which Mr. Justice Rutledge concurred, was also registered by Justice Murphy. The core of his dissent hinged on the argument that since these were criminal cases, there should be substantial evidence to support draft board classifications before review is denied. The "stakes are too high," he sald, "to permit an inappreciable amount of supporting evidence to sanction a draft board classification."132 The validity of the opinion "should be established by something more forceful than a wisp of evidence or a speculative inference."I33 Needless to say, Murphy felt that "the proof in these cases falls far short of justifying the conviction of the petitioners." 134 Because the consequences were much graver in cases where the punishment was criminal, unlike ordinary cases dealing with administrative orders, Murphy felt that care should be taken in setting up "standards which would allow the judge to do little more than give

132 Ibid., p. 458.

133 Ibid.

${ }^{134}$ Ibid. 
314

automatic approval to the draft board's action."135

Favoring the dissenting opinion of Douglas, Mr. Justice Murphy thought there was in this case undue discrimination. The intention of Congress he felt was not "to exempt from statutory duties those ministers who are forced to labor at secular jobs to earn a living s=s $n 136$ Any other view; he said:

- would ascribe to Congress an intention to discriminate among religious denominations and ministers on the basis of wealth and necessity for secular work, an intention that I am unwiling to impute. 137

In further accordance with the line of argument advanced by his dissenting colleague, Murphy said that the administrative action in the instant case denied the petitioners of having any "conscientious or religious scruples against war, or that he is a minister." 138 In all the cases dealing with conscientious objection thus far, the court was concerned about making available remedies in order to meet certain constitutional requirements of review. But in this case, both the dissenting opinions were concerned over the denial of the right of an Individual to object for "conscience' sake."

135Ibid., p. 457.

136 Ibid., p. 459 .

137 Ibid.

138Ibid., p. 458. 
315

The next Supreme Court case involving a Jehovah's Witness and his battle for exemption from military service was Dickinson v. United States ${ }^{139}$ which came six years after cox. Unlike Cox and all of the preceding cases, the Dickinson case arose from a violation of and conviction under the Universal Military Training and Service Act. As stated by Mr. Iustice Clark who delivered the majority opinion supported by five other Justices, the main issue before the Court was "whether there was a basis in fact for denying Dickinson's claim to a ministerial exemption under [the Act]." 140

In 1948, Dickinson claimed IV-D on the basis that he was a "regular" but not an ordained minister. ${ }^{141}$ At that time he was working 40 hours a week as a radio repalrman. The documents submitted to the board showed that he devoted an uncertain number of hours to "preaching" to the public. He was classifled as I-A in July of 1950. The Court did not question the validity of this classification.

Beginning in 1948 however, Dickinson filed a request for reclassification on the ground that his status of activity had been changed. Through sworn testimony and letters from

\section{U.S. 389 (1953). \\ 140Ibid., p. 390.}

14lThe Universal Military Training and Service Act (formerly entitied "Selective Service Act of 1948") to which Dickinson was subject described the activities of the "duly ordained" and "regular" minister. See Table in appendix. 
316

the Watchtower Bible and Tract Society, as well as from his "supervisors," Dickinson presented the following uncontroverted facts.

In the Spring of 1949, Dickinson voluntarily left his 40-hour-a-week job as a radio repairman and joined the Jehovah's Witnesses through baptism, a mark of ordination for that faith. He enrolled in Bible classes and became a "Pioneer" minister, preaching from door-to-door and devoting at least 150 hours per month to his new duties. In January 1950, Dickinson became a "Company Servant" (presiding minister), and moved to Coalinga California, designated as a Jehovah's Witnesses "Company" town. There, he was the presiding minister working as a missionary and delivering sermons to the public. He also taught Bible classes and instructed prospective ministers in the "Company's" Theocratic Ministry School. He received no salary for his services and for subsistence, he depended on part time work as a radio repairman. From his part time work he averaged about $\$ 35.00$ a month. His modest apartment cost him about $\$ 16.00$ per month, and through invitations to various homes he was enabled to subsist.

"Despite this uncontroverted evidence of marked change in Dickinson's activities, the local board continued him in I-A"142 in 1950. This was what was at issue before the court, said Clark. The appeal board affirmed the local board ruling, 
317

and Dickinson was ordered to report for induction on July 16 , 1951. He reported but refused to be inducted. He was then indicted and convicted by the district court and the court of appeals upheld the lower court decision. The Supreme court granted certiorari.

Glark pointed out that the Universal Military Training and Service Act, like the conscription Asts of 1917 and 1940, did not provide for judiclal review on classifications. Local board orders were in each case "final." But he made reference to the Estep decision and reiterated the oft-repeated rule that review may be provided "if there is no basis in fact for the classification which it [local board] gave the registrant."143

Although all members of various religious faiths are not exempt from service on their own belief that they are ministers, the court reasoned that:

On the other hand, a legitimate minister cannot be, for the purposes of the Act, unfrocked simply because all the members of his sect base an exemption claim on the dogma of its laith. That would leave a congregation without a cleric. 144

The Court felt that "Dickinson made out a case which meets the statutory criteria."145 And "since the ministerial exemption

$$
\begin{aligned}
& 143 \text { Ibid., p. } 394 . \\
& 144 \text { Ibid., pp. } 394-395 . \\
& 145 \text { Ibid., p. } 395 .
\end{aligned}
$$


is a matter of legislative grace, " 146 it was the registrant
who bore "the burden of clearly establishing a right to the
exemption." 147

This decision seems to come to this: that while a draft board classification is 'final' and is not subject to ordinary review in the courts, a measure of collateral review, either in a habeas corpus action or criminal prosecution is possible in the sense that the courts will inquire whether the board had 'jurisdiction.'148

It was the opinion of the court that the local board's continuation of the I-A classification, was conditioned by the petitioner's secular employment. Employing the argument of the corpulent versus the scanty similar to the dissenting opinions of Douglas and Murphy in Cox v. United States, supra, Clark said:

A statutory ban on all secular work would mete out draft exemptions with an uneven hand, to the detriment of those who minister to the poor and thus need some secular work in order to survive. To hold that one who supports himself by five hours of secular work each week may thereby lose an exemption to which he is otherwise entitled, would be to achieve a result that Congress so wisely avoided.149

The remainder of the majority opinion described the activity of local boards, noting that they were not courts of
146 Ibid.
147 Ibia.
148 FeIIman, A.P.S.R., XLIX, p. 85.
149 Dickinson v. United States, p. 395. 
319

law therefore not bound by traditional rules of evidence. "They are given great leeway in hearing and considering a variety of materlal as evidence." 150 When facts are disputed, it was the board's responsibility to resolve the conflict. Courts would not interfere. "However, the Courts may properly insist that there be some proof that is compatible with the registrant's proof of exemption."15I Local boards were given wide authority and were free to engage in a variety of investigative practices. They could even call upon federal agencies to aid them in obtaining facts and information. Even their erroneous classifications were not subject to review.

But when the controverted evidence supporting a registrant's claim places him prima facie within the statutory exemption, dismissal of the claim solely on the basis of suspicion and speculation is both contrary to the spirit of the Act and foreign to our concepts of justice. 152

The decision of the lower court was therefore reversed by the supreme court.

Mr. Justice Jackson, with whom concurred Justices Burton and Minton, dissented on the ground that the Court here was weighing evidence and determining factual questions which it had not the power to do. If Estep established any rule, it

150Ibid., p. 396.

15I Estep v. United States, p. 122 .

152Dickinson v. United States, p. 397. 
forbade the courts from reviewing such a case.

Jackson pointed out that the petitioner at the time of his registration was only 18 years old, and throughout the whole process of litigation, the records showed that his actions and his youth "raised doubts as to his good falth."153 If the board doubted or disbelieved petitioner's testimony in part, the record itself raised the suspicions and the decision of the board was not altogether groundless. This action, thought Jackson, was not within the scope of court review. What the majority was doing in the instant case, was to require the board to build a substantial "record of affirmative evidence that he has misrepresented his case," 154 sald Jackson, when there was "nothing in the Act which requires this result." 155

Some sixteen months after Dickinson, the Supreme Court granted certiorari on four cases 156 involving Jehovah's Witnesses who refused to comply with selective service board orders, and were convicted of violating the Universal Military TrainIng and Service Act. Mr. Justice Clark, who delivered the majority opinion in each case, explained; "Because of the wide divergencies in the problems presented, we shall consider the

153 Ibid., p. 398.

154 Ib1d., p. 399.

155 Ib1d.

156 The first of these was Witmer v. United States 348 U.S. 375. The other three are discussed below. 
cases before us in separate opinions. 157 The Witmer case, the first of the series, was quite similar in fact to the Dickinson case. In Witmer, the court clarified and applied the Dickinson rule.

In January 1951 witmer filed his classification questionnaire stating that he worked 40 hours per week in a hat factory. He requested agricultural exemption claiming that he intended to increase production on his father's farm in order to "contribute a satisfactory amount for the war effort and civilian use."I58 In the original questionnaire he expressly disclaimed ministerial exemption. He did claim to be a conscientious objector although he falled to fill in the proper forms.

On February 1951, the local board classified Witmer I-A. Eight days later he wrote the board advising them that he intended to appeal their action and request a classification of a minister. During the eight-day period, witmer left his job and secured an affidavit from a local officer of the Jehovah's Witnesses stating that he was engaged in full time "preaching" activity. At the conclusion of the hearing the board felt that he was not entitled to a ministerial exemption, but agreed to submit the case to the appeal board following a physical examination.

In accordance with the Act, the appeal board forwarded

$$
\begin{aligned}
& 157_{\text {Ib1d.., p. } 376 \text { N. } 1 .} \\
& 158 \text { Ib1d., p. } 378 .
\end{aligned}
$$


the case to the Department of Justice. The F.B.I. report showed that the registrant was "religious" and at times indicated publicly that going to war was "wrong." At the hearing conducted by the Justice Department, Witmer said that he could not engage in noncombatant service because "the boy who makes the snow balls is just as responsible as the boy who throws them." I59 on the basis of the entire record, the hearing officer suggested a conscientious objector classification.

The Department of Justice, however, concluded that Witmer's inconsistent statements, together with his offer to contribute to the war effort, preciuded such a classification and recommended to the appeal board that Witmer's claim be denied.160

After due consideration, the board retained the original I-A classification and ordered the registrant to report for induction. Witmer refused, and was indicted and convicted. Clark relterated a well-established principle, "There is no direct judicial review of the actions of the Appeal Boards."161 In considering the primary question under the narrow scope of review given to the courts, the issue was whether the facts in this case permitted the court "to overturn the Selective Service System's refusal to grant petitioner

159 Ibid., p. 380 .

160 Ibid.

${ }^{161}$ Ibid., p. 377 . 
conscientious objector status," 162 clark said. "It is well to remember that it is not for the courts to sit as super draft boards。"163 The classification could be overturned only if it had no basis in fact, Estep v. United States, and Dickinson v. United States, supra. In differentiating this case from Dickinson, Clark said "the objectlve facts on which Dickinson based his claim as a full-time minister were disputed. . "I64 In other words, unlike Dickinson, Witmer failed to "demonstrate his sincerity." Then Clark expressed the core of the problem which the Court had carefully avoided for so long. Objective facts alone do not always suffice "because the ultimate question in conscientious objector cases is the sincerity of the registrant in objecting, on religious grounds, to partictpation in war in any form."165 In Dickinson the registrant made out his prima facie case on objective facts alone which were deemed sufficient, but in the instant case this was not true. "In conscientious objector cases, therefore, any fact which casts doubt on the veracity of the registrant is relevant." 166

Some of the reasons for the court to doubt the sincerity

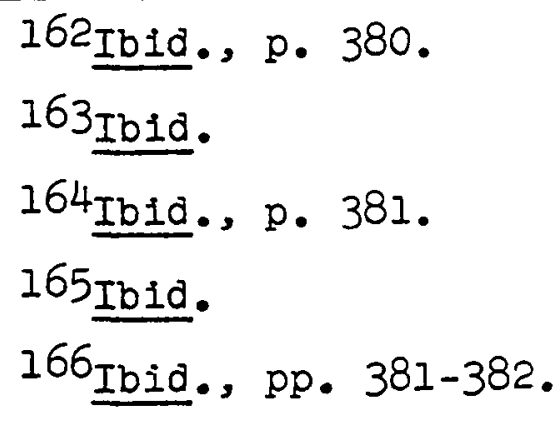


of the registrant were: (I) his stated purpose to cultivate a land which for 23 years had been lying idle except for a few acres used for family purposes; (2) his claim to ministerial exemption after being denied his claim to an agricultural exemption. (3) his intention of growing crops to help the war effort as agaipst his statement that "the boy who makes the snow balls is just as responsible as the boy who throws them." This was not merely a case of a registrant claiming three separate exemptions, "it goes to his sincerity and honesty in claiming conscientious objection. . "167 In denying the request of the registrant, the board was therefore not acting merely on suspicion and speculation. "In short, there was basis in fact for the board's decision."168

According to the instant decision, in conscientious objector cases, the court will first of all recognize "conscientious objection based on religious grounds."169 secondly, although the determination of the sincerity of a person's belief is highly subjective, inasmuch as this judgment can best be reached by objective evidence, the court will put great weight on objective facts in determining a person's sincerity.

\section{Ibid., p. 383. 168 Ibid.}

169Edward A. Fitzpatrick, Universal Military Training (New York: McGraw Hill Book Co., I945), p. 293. The author discusses other types of conscientious objection, e.g., philosophical, humanitarian, economic, etc. But says the court will recognize only that which is based on religious grounds. 
The term "sincerity" was not a criterion to determine "basis in fact" until the Witmer case. Thus conscientious objector cases took on added problems although general constitutional rules became more distinguishable.

Justices Black and Douglas dissented without recording their opinions, and Justice Minton concurred with the result of the case.

More than any other single conscientious objector case involving Jehovah's Witnesses, Sicurella v. United States, 170 generated public response. This was one of the four cases handled by the court at the same time but were decided in separate opinions. The main issue centered on statutory construction as applicable to persons who object "to participation in war in any form." 171

Sicurella was born of parents who were members of $\mathrm{Je}-$ hovah's Witnesses and was himself a life-long practitioner of the faith. He was baptized at 6 , consecrated at 15, and ordained when 17. In 1948 he was classified as a minister although he worked 44 hours a week for the Rallway Express Company. In 1950 he was reclassified for military service. ShortIy thereafter he filed claim as a conscientious objector.

In the special clalm form he made certain statements which were the main cause for the refusal of the board to grant

170348 U.S. 385 (1955).

17150 U.S.C. app. (1952) ed., See 456 (j). See Table 3 in appendix. 
his request for a classification as a conscientious objector. In answer to some of the questions contained in the questionnalre, he made it known that he was not opposed to all wars. He would fight, he said, in a "theocratic war," especially to preserve the interests of God's Kingdom, and if necessary for "our fellow brethren, sisters, and our property against attack." 172 Upon a denial of his claim by the local board, Sicurella appealed and his records were submitted to the Justice Department. After the investigation, the hearing officer reported that the petitioner's claim seemed to be sincere and in order. Admitting that the report of the hearing officer was favorable to the petitioner, the Justice Department nevertheless recommended the appeal board to deny petitioner's claim on the ground that:

While the registrant may be sincere in the beliefs he has expressed, he has, however, falled to establish that he is OPPOSED TO WAR IN ANY FORM. - He is, therefore, not entitled to exemption within the meaning of the Act.173

The board of appeal retained the I-A classification and ordered the registrant to report for induction. He refused, and he was convicted by the lower court whose judgment was affirmed by the circuit court of appeals. The Supreme court granted certiorari. The majority decision by Clark differentiated the instant

172 Sicurella v. United States, p. 387.

173 Ibid., p. 388. Italics supplied. 
327

case from witmer in that there was here no question of sincerity.

The only question presented in this case is one of law -- do the beliefs which petitioner says he holds amount to the conscientious opposition to 'participation in war in any form' demanded by congress as a prerequisite to the conscientious objector deferment? 174

Clark noted that throughout the questionnaire filled out by the registrant, he indicated that the war in which he would -and was -- engaged was a spiritual war. His meapons too were spiritual, and not carnal. He claimed to be in the Army of Jesus Christ, and that "the war weapons of the soldier of Jesus Christ are not carnal."175 The statements made by the petitioner "on their face. - make it clear that petitioner's defense of 'Kingdom Interests' has neither the bark nor the bite of war as we unfortunately know it today."176 In this connection, the court said that the willingness of a person to defend himself when attacked was not the kind of activity Congress had in mind when it passed the Act. Should the Court grant that Jehovah's Witnesses were antipacifists on the basis that they were not opposed to a "theocratic war," and became direct participants of such;

$$
\begin{aligned}
& 174 \text { Ibid., p. } 388 . \\
& 175 \text { Ib1d., p. } 389 . \\
& 176 \text { Ib1d., p. } 390 .
\end{aligned}
$$


328

- . and granting that the Jehciah's Witnesses will

fight at Armageddon, we do not feel this enough.

The test is not whether he is opposed to all war,

but whether he is opposed, on religious grounds,

to PARTICIPATION in war. 177

Clearly, the Court was interpreting the law as it felt Congress had intended at the time the law was passed. The emphasis was upon PARTICIPATION, rather than WAR IN ANY FORM. In describing what the Court felt Congress had intentioned, Clark said:

We believe that Congress had in mind real shootIng wars when it referred to participation in war in any form -- actual military conflicts between nations of the earth in our time -- wars with bombs and bullets, tanks, planes and rockets.178

The Court further believed that the reasoning of the Government "is so far removed from any possible congressional intent that it is erroneous as a matter of law."179

Clark thought that the decision of the appeal board was based on the recommendation of the Justice Department whose report was based on the petitioner's willingness to "fight under some circumstances, namely in defense of his ministry, Kingdom Interests, and in defense of his fellow brethren."180 This, to the Justice, was an error of law which "must vitiate the entire proceedings at least where it is not clear that

177 Ibid.

178 Ibid., p. 391.

179 Ibid.

180 Ib1d., p. 392. 
the board relied on some legitimate ground."181 pointing to a list of lower court decisions, Mr. Justice Clark declared:

Here, where it is impossible to determine exactly on which grounds the Appeal Board decided, the integrity of the Selective Service system demands, at least, that the Government not recommend 11legal grounds.182

The Court therefore reversed the decision of the lower court. In doing so, the Court said that "the draft law concerns only here-and-now shooting wars," 183 and did not include those who fight in wars by command of God.

Mr. Justice Reed dissented on the basis that Sicurella's contention did not meet the statutory test. Theocratic wars, such as those commanded by God to the Israelites, were "blood and flesh wars."184 Reed also noted that although the number of people excused from combat was actually small and therefore unimportant to the country's military strength, it was unfair to other American citizens without such scruples against war who must be exposed to danger while a few continue to work without being so exposed.

\section{${ }^{18 I_{\text {Ibid. }} .}$ \\ 182 Ibid. \\ 183"Jehovah's Witnesses Win again in supreme Court,"} Christian Century IXXII, No. 13 (March 30, 1955), p. 12. This article praised the decision and said that the Supreme court "showed common sense" in the Sicurella opinion.

184 Sicurella v. United States, p. 393. 
330

Mr. Justice Minton dissented on two grounds. His first argument was basically the same as Justice Reed's. Because the petitioner was not opposed to "participation in war in any form," he failed to meet the congressional test. Minton felt that the petitioner's willingness to defend himself and Kingdom Interests was proof that he came within the scope of the Act. The second ground on which Minton based his dissent was the Estep rule.

It is not our province to substitute our judgment of the facts for that of the Board or to correct the Board's errors of law unless they are so wanton, arbitrary and capricious as to destroy the jurisdiction of the Board.185

Where there was an honest mistake, the courts could not interfere, and to Minton, if the board had been mistaken in this case in accepting the Justice Department's recommendation, it was an honest mistake over which the Court had no review. As a matter of differentiation from the Witmer case, in Sicurella case:

The Court held that exemption should have been granted even though the draftee said he might use force in self-defense and in defense of the interests of the Witnesses of Jehovah. But a different conclusion was reached in the Witmer case because the draft board had before It facts sufficient to justify its conclusion that the registrant was not sincere in his claim to be classified as a conscientious objector.186

185 Ibid.

1860smond K. Faenke1, The Supreme court and Civil 
331

The third of the four cases of conscientious objection involving the Witnesses was Simmons v. United States. 187 The petitioner, Simmons, registered in 1948 while he was employed as a chauffeur at the Great Lakes Naval Training Center. At that time he was classified I-A and did not oppose the classification. In 1949 he married and was given a dependency deferment in June 1951. Within a week after his restoration to I-A, he filed conscientious objector forms.

The forms filed by the petitioner revealed that he became a member of the Jehovah's Witnesses in 1949. He then conducted Bible study courses and by December of 1950 he became an unordained minister, and an ordained minister in October 1951.188 He appeared before the board and requested ministerial exemption rather than an exemption as a conscientious objector. His request was denied and his classification of I-A was retained. On appeal, the appeal board found against him, and referred the case to the Department of Justice.

After an investigation by the F.B.I., the petitioner was notified to appear before a hearing. The Court noted that no copy of this notice appeared in the files. The regular forms sent to registrants during the period in question stated that "the hearing officer would advise the registrant as to

Liberties (New York: Oceana Publications Inc., 1960), p. 69. 187348 U.S. 397 (1955).

188 According to the practices of the Jehovah's Witnesses, there are ministerial gradations. 
332

the general nature and character of adverse evidence of the F.B.I. report"189 if the registrant would request such information. The registrant made this request at the hearing, but there was no evidence that he made the request prior to the hearing. The case came to the supreme court on certiorari after the circuit court of appeals affirmed the judgment of a lower court sustaining the board action to compel the petitioner to report for duty.

Mr. Justice Clark referred to United States v. Nugent 190 as the controlling case in this instance. The specific reference in Nugent was the requirement placed upon the Justice Department to supply the registrant "with a fair resumé of any adverse evidence in the investigator's report." 191 If therefore, "the balance struck in Nugent is to be preserved," said Clark, "the registrant must receive the fair summary to" which he is entitled."192

In requiring the Department to supply the registrant with a resume of any adverse evidence, the Court recognized that this "did not entail disclosure of secret reports, "193 but there must be some means afforded the registrant to dispel

189 Ibid., p. 399.

190346 U.S. I (1953).

191 Ibid., p. 6 .

192 simmons v. United States, p. 403. 193Ibid. 
333

the charges. The court described a fair resumé as one "which will permit the registrant to defend against the adverse evidence -- to explain, rebut it, or otherwise detract from its damaging force." 194

While the question of sincerity was not an issue in this case, the decision of the board was conditioned by the character of the petitioner. Police records revealed that he was booked and jailed for beating his wife in 1950. The files also showed that the police were called several times to settle "hot arguments," and as late as January 1952, his wife made claims that the registrant was abusive.195 certain informants testified to the petitioner's character and revealed that prior to becoming "religious," he spent most of his time around pool halls and was often engaged in gambling and drinking. Although the statements provided by the informants disclosed that "the petitioner had changed his ways and now seemed sincere,. . .the disclosure of petitioner's gambling and drinking activities was certainly adverse."196 The hearing officer himself admitted that the registrant impressed him as being sincere but because his religious activities coincided with pressure from the Draft Board, he recommended

194 Ibid., p. 403.

195 The domestic affairs of the registrant were noted by the court rather extensively in the footnotes of the case. Ibid., pp. 400-403. Nn. 2-3. 196 Ib1d., p. 402 N. 3. 
In addition to the fact that his religious activities coincide with pressing induction possibilities, registrant's absorption and sincerity as to his newly found religion is rendered more questionable by $h$ is abusiveness and the exercise of physical violence towards his wife. 197

In considering the more important issues of the case, the Court felt that the Government's contention that the petitioner was given proper notice through the hearing officer did not "convey clearly to the layman the ldea that he must make a request for the resume prior to the hearing or forever waive his rights in this respect."198 That the petitioner "never received a fair resumé gleaned by the F.B.I. seems hardly arguable,"199 sa1d the court.

The constitutional issue was over the contention of the petitioner that the Department of Justice deprived him of a proper hearing as prescribed in Section $6(j)$ of the Universal Military Training and Service Act, by a failure to furnish him with a fair resumé of all adverse information in the F.B.T. report. Under the conditions examined, the court noted that the petitioner was denied a proper hearing, and therefore reversed the lower court judgment.

$$
\begin{aligned}
& 197_{\text {Ibid., N. }} . \\
& 198_{\text {Ibid.. }}, p_{.} 404 . \\
& 199 \text { Ibid. }
\end{aligned}
$$


335

The court further argued that unlike other "fair hearing" cases arising under due process considerations, "This is not an incidental infringement of technical rights."200 He was deprived of a fundamental right and therefore, "need not specify the precise manner. . . and how such use would have a1ded his cause. . . in order to complain of the deprivation."201 From an overall point of view, the hearing itself was "lacking in basic fairness."202

Justices Black and Douglas joined the opinion on the basis of their dissent in Nugent v. United States, supra.

Justices Reed and Minton dissented. The former dissented on the ground that no summary was necessary since none was requested; the latter dissented on the basis of his dissent in Sicurella. There was here no arbitrary or capricious action by the board and the judgment of the board should be permitted "even if erroneous,"203 said Justice Minton.

The last of the four subject cases, Gonzales v. United States $^{204}$ came before the Supreme Court under the same general

$$
\begin{aligned}
& 200 \text { Ibid., p. } 406 . \\
& 201 \text { Ibid. }
\end{aligned}
$$

202Ibid., p. 397. This doctrine is unusual in the light of previous decisions. If "basic fairness" is a criterion to review cases, the door is open for all sorts of attack. "Basic fairness" is obviously quite different from "basis in fact."

$$
\begin{aligned}
& 203 \text { Ib1d., p. } 406 \text {. } \\
& 204348 \text { U.S. } 407 \text { (1955). }
\end{aligned}
$$


conditions as the others.

The petitioner, Gonzales, was born in 1931 in San Antonio, Texas, of Roman Catholic parents. He left high school after completing only two years. In 1948 he married a woman who was a member of a Jehovah's Witness since 1941. Together they moved to Detroit in 1949, and at the time he registered with the local board in 1950, he was employed by the Great Lakes Steel Corporation. Unlike Simmons, the records showed that there was no evidence of domestic difficulties. The testimony of fellow workers, other members of Jehovah's Witnesses, neighbors, and even the F.B.I. reports showed that Gonzales was a religious person and sincere in his beliefs.

In September of 1950, the petitioner was recognized by the Jehovah:s Witnesses as a "Pioneer" and he embarked on an extensive program of religious activity. In April 1951, petitioner filed claim for conscientious objector status on the ground that his personal "knowledge of the Bible"205 led him to refuse participation. He said he believed in the use of force to protect persons and ministerial activities" but at no time in aggression."206

After an intervening dependency classification (III-A), on January 8, 1952, he was classified I-A. The appeal board made a tentative finding against him and referred the case to

205Ibid., p. 409. ${ }^{206}$ Ibid. 
the Department of Justice. The F.B.I. conducted an investigation and the petitioner was granted a hearing. The officer, although convinced that the petitioner was sincere in his beliefs nevertheless recommended denial of conscientious objector classification. The Justice Department made a similar recommendation to the board of the appeals mainly on the ground that the registrant became a member of the Jehovah's Witnesses "one month after his registration in 1950, despite the fact that his wife had been a member for many years."207 It was the opinion of the hearing officer that the

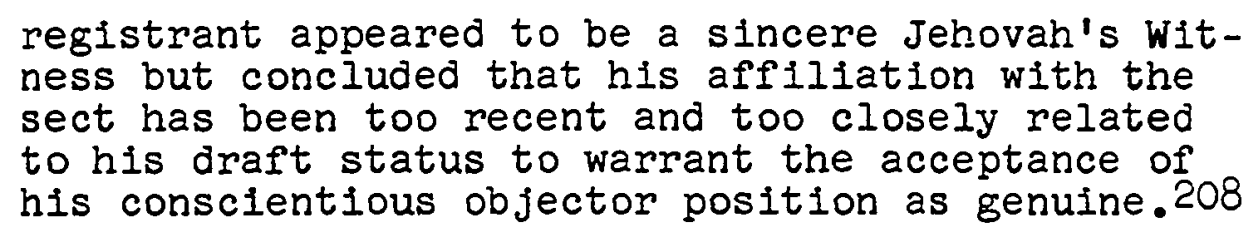

In evaluating these two facts, namely, the petitioner's wife's long-time membership, and his own very recent adherence to the sect, the board felt that they "lend weight to this conclusion."209 The main issue before the court was whether under section $6(j)$ of the Universal Military Training and Service Act, the petitioner "was entitled to receive a copy of the recommendation made by the Justice Department to the Appeal Board."210

$$
\begin{aligned}
& 207 \text { Ibid., p. } 410 . \\
& 208 \text { Ibid., p. } 411, \mathrm{~N} .2 . \\
& 209_{\text {Ibid. }} \text {, reiterated on p. } 413 . \\
& 210 \text { Ibid., p. } 408 .
\end{aligned}
$$


338

Mr. Justice Clark speaking for the majority thought he did. The Court acknowledged that the Act remained silent as to the requirement that the petitioner be given a copy of the recommendation, "But a similar silence was not considered rejection of the right of a registrant to be supplied with a fair resumé of adverse evidence, United States $v$. Nugent, and Simmons v. United States, supra."2ll it was implicit in the Act that procedural regularity and basic fair play, compelled the agency to furnish a copy of the recommendation in order to afford the registrant a fair opportunity to reply. The Court pointed out that

- . if the registrant is to present his case effectively to the Appeal Board, he must be cognizant of all facts before the Board as well as the overall position of the Department of Justice.212

In denying the registrant a copy of the recommendation in the instant case, the board denied him the right to rebut the claim of the Justice Department that the registrant only recently became a member of the Jehovah's Witnesses. The petitioner therefore was not given the opportunity to explain that he had forsaken the Catholic belief since 1948, and was "converted" to the sect shortly thereafter. The Department of

\section{Ib1d., pp. 411-412.}

212Ibid., p. 413. The court here put reliance upon Ohio Bell Telephone Company v. Public Utilities Commission, 301 U.S. 292 (1937); United states v. Abilene and Southern

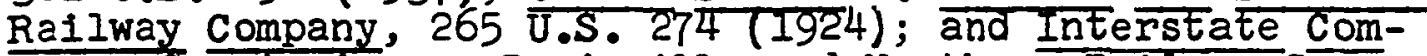
merce Commission v. Louisvilie and Northern Railway Company, $2270.5 .88(1913)$. 
Justice had based its rejection of the petitioner's claim "on the proximity of petitioner's conversion to his registration for the draft, a contention of which he had no knowledge and no opportunity to meet." 213

The court noted that a chance to answer was a "prime requirement of any fair hearing"214 over which the Government was quite aware, for the counsel in his oral argument stated that the registrant was "amply protected by the provision in the regulations for a mode of 'rehearing." 215 But "We believe these remedies to be too little and too late,"216 said: the court.

Too little, because the right to present petitioner's side of the case is broader than the bare right to correct 'errors' made by the $\mathrm{De}-$ partment in its recommendation. Too late, because, except with the permission of the national or state director, only the local board may reopen the case; and a certain reluctance is to be expected after the Appeal Board, albeit on incomplete presentation, has rejected the registrant's claim.217

Mr. Justice Reed, Justice Burton concurring, dissented on the ground that there was "no express or implied statutory

$$
\begin{aligned}
& 213 \text { Ibid., p. } 414 . \\
& 214 \text { Ibid., p. } 416 . \\
& 215 \text { Ibid. } \\
& 216 \text { Ibid., p. } 417 . \\
& 217 \text { Ibid. }
\end{aligned}
$$


340

or administrative requirement that the Department of Justice send to petitioner a copy of its advisory report to the Appeal Board."218 Furthermore, the report of the Justice Department was only advisory, the decision was made by the board and therefore final.

Mr. Justice Minton's dissent was based on the reasoning of his previous dissents, to wit, the decision of the board was neither arbitrary nor capricious, therefore it had not lost jurisdiction. Minton went along with Reed in thinking that the petitioner was not entitled to a copy of the recommendation because the regulations did not require it, and the petitioner had not requested it.

The next case of any import brought before the supreme Court by members of the Jehovah's Witnesses sect who refused to serve in a national program on the basis of their conscientious objection was in the middle of 1956.219 During the interim, the Court handed down three per curiam decisions; Bates v. United States, ${ }^{220}$ Simon v. United States, ${ }^{221}$ and De Moss v. United States. ${ }^{222}$ In Bates and Simon, the court granted

${ }^{218}$ Ibid.

219Johnston et. aI. v. United States, 351 U.S. 215 (1956). Discussed below. $220_{348}$ U.S. 966 (1955).
$221_{348}$ U.S. 967 (1955).
222349 U.S. 918 (1955). 
341

certiorari and reviewed the question in which the petitioners claimed that their request for conscientious objection had been denied by the appeal board without proper hearing and an opportunity to study the report. The court reversed the conviction rendered by the lower courts on the ground that the "procedure prescribed by Section $6(j)$ of the Universal Military Training and Service Act has not been complied with. . ."223 In De Moss, upon petition for certiorari, the Court heard a case in which there was a confession of error by the Government. On this confession and on the authority of Bates, the court reversed the lower court conviction.

A year later, the Court heard and gave a judgment in Johnston et. al. v. United States together with United States v. Patteson. 224 The main issue in these cases was in determining the proper venue of the trials.

The petitioners, Johnston and Sokol, resided in the Western Judicial District of Pennsylvania. In lieu of their induction, both were classifled as conscientious objectors and ordered to report to separate state hospitals located in the Eastern Judicial District. "The indictments were dismissed for lack of jurisdiction on the ground that venue could only be in the Western District."225 The court of appeals reversed

$$
\begin{aligned}
& 223_{\text {Bates }} \text { v. United States, supra. } \\
& 224351 \text { U.S. } 215(1956) \text {. } \\
& 225 \text { Ibid., p. } 216 .
\end{aligned}
$$


342

and remanded the case for trial, reasoning that venue was there and the registrants failed to report.

Likewise in the patteson case, registrant was classifled as a conscientious objector and ordered to report to his local board in Oklahoma for assignment. He reported to the board but when he was ordered to report to the Kansas State Hospital in Topeka, he refused to comply with the orders. He was indicted in Kansas, but the Kansas district court ordered the case transferred to Oklahoma. The Oklahoma court transferred the case back to Kansas thinking the venue was there. The Kansas court then dismissed the case on the ground that the venue was in Oklahoma. The court of appeals affirmed the judgment. The Supreme court accepted the case on certiorari, and Justice Reed speaking for the majority said:

Our analysis of the law and the facts in these cases convinces us that the venue of these violations of the orders lies in the district where the civilian work was to be performed, that is, for Patteson in Kansas, and the Eastern District of Pennsylvania for Johnston and Sokol.226

This conclusion was reached by the court under "the general rule that where the crime charged is a fallure to do a legally required act, the place fixed for its performance fixes the situs of the crime."227 Although Article III of the Constitution

226 Ibid., p. 220.

227Ibid. Here, the Court relied mainly on Rumely $\mathrm{V}$ McCarthy, 250, U.S. $283^{\prime}$ (1919); United States v. Lombardo, 241 0.S. 73 (1916); and cases cited In United States v. Anderson, 328 U.S. 699 (1946). 
and the Sixth Amendment fix venue in the "State," and the "district wherein the crime shall have been committed," they "do not furnish guidance for determination of the place of crime"228 said the court. That place was actually determined by the acts of the violator. This general rule "fixes the situs of the trial in the vicinage of the crime rather than the residence of the accused."229 Reed felt that a variation of the rule for the sake of convenience of either the prosecution or the accused was not justified and would only cause delay and confusion.

Justice Reed argued that under the Act, the petitioners falled to comply with their "second duty." Although the order could be the basic of only one conviction, the order to report to work was the second phase of the procedure. The "failure to proceed to the place of employment pursuant to instructions"230 constituted a crime. And in this case "the crimes charged arise from failure to complete the second duty -- report for employment. Accordingly venue must lie where the failure occurred."231

$228_{\text {Ibid. }}$

229Ibid., pp. 220-221. According to Professor Fellman, "Since the was no showing that an arbitrary action had taken place, he [Reed] took the position that the possibility that the registrants might be ordered to report to remote points did not require changing the law of venue." See "Constitutional

Law in 1955-1956," A.P.S.R., LI (March, 1957), p. 171.

230 Ibid., p. 22.

${ }^{23}{ }_{\text {Ibid. }}$ 
Mr. Justice Douglas, Chief Justice Warren and Mr. Justice Black concurring, dissented on the ground that when a registrant adamantly refuses "to budge from his home town and stays at home defying the local authorities, the crime has been committed at home."232 In a case of this nature, if there were any doubts at all, they should be resolved in favor of the citizen.

Citing history, Douglas pointed out that when the British Parliament sought to take Americans abroad, or to another colony for trial, "the Virginia Resolves of May 16, 1769, voiced the unanimous view that 'thereby the inestimable privilege of being tried by a jury from the vicinage". . "233 was being taken away. In the instant case, the objectors suffered comparably, said the Justice.

For their defiance of their local boards they are sent to distant places for trial where they have no friends, where they are unknown, and to which all witnesses must be transported. Congress would have the power to fix the venue there. But it has not done so unambigous 1 y.234

Justifying his argument, Douglas explained that he "would read the statute with an eye to history, "235 and try the offenders

$$
\begin{aligned}
& 232 \text { Ibid., p. } 223 . \\
& 233 \text { Ibid., p. } 224 . \\
& 234 \text { Ibid. } \\
& \text { 235 Ibid. }
\end{aligned}
$$


in their own area of residence where they defied the authorities.

There was a lapse of approximately four years before the Court again entertained and decided on a conscientious objector case involving a member of the witnesses. As if to lend further confusion, the case was entitled Gonzales v. United States, 236 identical -- in name -- to a previous case.237 The main constitutional question involved due process under the Fifth Amendment. The petitioner claimed that due process was denied "both in proceedings before a hearing officer of the Department of Justice and at trial."238

The petitioner, Gonzales, first registered with the 10cal board in Boulder, Colorado, on March 17, 1952. Although he claimed to be a minister of the Jehovah's Witnesses on the questionnaire, the board classified him I-A in November 1952. Thereupon he immediately wrote to the board stating that he was a "regular minister" devoting at least 100 hours to public preaching each month. In addition, he claimed to be doing other ministerial duties involving 50 to 75 hours per month. He was therefore classified I-O. After one of its periodic reviews, the local board reclassified the petitioner I-A in April 1953. This decision of the board was based on two

$$
\begin{aligned}
& 236_{364} \text { U.S. } 59 \text { (1960). } \\
& 237348 \text { U.S. } 407 \text { (1955). } \\
& 238_{\text {Gonzales v. United States }}(1960), \text { p. } 60 \text {. }
\end{aligned}
$$


grounds. (1) In a personal appearance of the registrant he claimed that he was willing to $\mathrm{klll}$ in defense of the church. (2) In the past six months he discontinued devoting "100 hours" per month to his preaching activities. The headquarters of the Jehovah's Witnesses corroborated this fact by reporting that the petitioner was no longer a full-time "Pioneer," and was devoting about $6 \frac{1}{2}$ hours per month to his public preaching. The registrant was ordered to report for induction on June 11, 1956, but refused to do so. Although the petitioner was not prosecuted, in the light of the Sicurella case, the case was reopened. There followed the customary procedure of hearings by the agency and appearances by the registrant. The Justice Department recommended that the registrant be classified I-A on the ground that his claim was "so highly exaggerated," that it "cast doubt upon his veracity and, consequently, upon his sincerity and good faith."239 A copy of this recommendation was furnished the registrant. The appeal board unanimously concurred with the Department's recommendation and ordered the registrant to report for induction. He refused, and prosecution followed. The case came to the Supreme court on certiorari after the appeals court affirmed a lower court judgment of conviction.

While Chief Justice Warren, joined by three associates, protested quite vigorously, the main issue in the case was

$$
{ }^{239} \text { Ibid., pp. 61-62. }
$$


347

centered on the question of whether the administrative procedure prescribed by the Act was fully complied with. Justice Clark, delivering the majority opinion answered in the affirmative.

The petitioner first contended "that the Department denied him procedural due process by not giving him timely opportunity. . to answer the statements of the local board"240 concerning the time he devoted to preaching activities. To this, the court said the local board's statement was in the registrant's file which was open to him and he admitted knowledge of it. Therefore, said the court, "he could have rebutted it before the hearing officer."241

The petitioner further contended that he was denied access to the hearing officer's report. Although section 6 (j) of the Act required the Department's recommendation be placed in the registrant's file, and the Court so held in the first Gonzales case, "there is nothing in the Act," said clark, "requiring the hearing officer's report to be likewise turned over to the registrant."242 In the whole process, the petitioner was afforded ample records and time to rebut the claims of the local board; "petitioner cannot now claim that he was denied the due process because he did not succeed."243

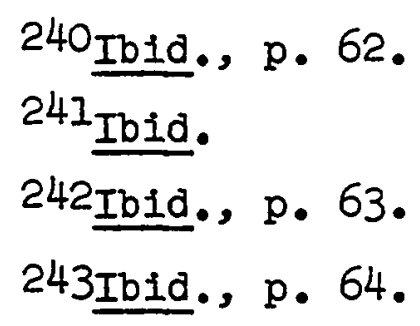


348

Finally, the petitioner claimed that he was entitled to examine the FBI reports. But the court reasoned that he was furnished a resumé, all that was necessary to meet procedural guarantees. His contention was based on the "right to explore, [hoping] to find some discrepancy in the resumé."244 But "the statutory scheme for review within the selective service system. . entilles /conscientious objectors] to no guarantee that the FBI reports must be produced for their inspection." 245 Even without the Nugent rule, Clark felt that the registrant was not entitled to the FBI reports since the decision of the appeal board was based entirely on the local board file, and the recommendation of the Department, not the FBI reports. Clark, a former Attorney General, took the liberty to explain in detail the intricate system of this whole process which directly involved the Department which he formerly drected.

Estep too, was recognized as controlling because "actions are final" and cannot be overturned unless "there is no basis in fact for the classification."246

In a dissenting opinion joined by Justice Black, Douglas and Brennan, Chief Justice warren lashed out at the majority saying, "I cannot belleve that this procedure comports with

244

Ibid., p. 65.

245Quoted from United States v. Nugent, pp. 5-6. Ibid. $246_{\text {Ibid. }}$ 
Congress' intent."247 This was to him a "guessing contest." He made special claims for the unquestionable character of the petitioner, noting that every report, from personal testimony to the FBI files, verified the integrity and sincerity of the registrant. Warren discussed at length the moral character of the petitioner saying that his religious beliefs appeared to be very genuine. His grade-school teachers said he was very cooperative and manneriy; he refused to salute the flag on religious grounds; all of his employers found him to be an excellent worker; he was an active "church-goer;" he was consistent in his life with stated beliefs; and his character, conduct, and reputation were very favorable. 248

The Chief Justice pointed out that the majority "cast doubt on his veracity" on the strength of one single item appearing in the file, that was, the registrant claimed in 1952 he devoted at least 100 hours per month to public preaching, while in 1956, the records indicated that he devoted only $6 \frac{1}{2}$ hours to such. The petitioner, according to warren, wrote the appeal board saying no related statement of any sort was made by him in 1956, therefore, "I would like to make it plain that I in no manner ever exaggerated my report concerning my antivities." 249 In his letter to the board he was quite disturbed

247 Ibid., p. 73 .

248 For a full description of the registrant's character, see text of the dissent. Ibid., pp. 67-68. 249 Ibid., p. 70. 
350

over the fact that he could be accused of lying:

The striking thing about this case -- aside from the dishonoring of the petitioner's claim -- is that he never once recelved a real opportunity to persuade any Department or selective service officer face to face that he had not lied to the local board, for the accusation was never made until petitioner's opportunity for oral response had passed. 250

Mr. Chief Justice Warren noted that the petitioner was allowed to file a rebuttal before the board of appeal, "but that rebuttal was WRITTEN, not oral."25l In determining credibility, the Chief Justice felt that "it can hardly be maintained that this afforded petitioner a fair opportunity to meet an accusation determinative of his case."252 It was his feeling that "the Department should have taken the initiative in telling Gonzales what he had to refute, rather than to leave it to an uncounseled young man to search the file himself."253

To Mr. Chief Justice Warren, the strict adherence to rules and their indiscriminate ritualistic administration were not enough to meet due process requirements in all cases. The petitioner, of course, was provided certain procedural opportunities, but the Chief Justice thought it not amiss to consider that the petitioner was only 22 years of age, "a

250 Ibid., p. 71 .

251 Ibid.

252 Ibid., pp. $71-72$.

253David Fellman, "Constitutional Law in 1950-1960," A.P.S.R., LV (March, 1961), pp. 114-115. 
351

laborer with but an eighth grade education. . .and unrepresented by counsel."254 The Chief Justice harbored doubts.

that anyone would maintain that there would be a hearing in any true sense of the word if such a person were told by the Department that he could appear and say whatever he wished, but that the Department would not indicate to him what it considered conclusive unless rebuited.255

That no one would contest the issue as stated, the Chief Justice was confident, but, he said, "in substance this is exactly what happened here."256 Neither was the majority decision consistent with the holding in Morgan v. United States 257 said Warren. In that case the court held that "those who are brought into contest with the Government. . are entitled to be falrly advised of what the Government proposes and to be heard upon its proposals before it issues its final command." $25^{8}$ "I do not believe," said Warren, "that the claim of Raymond Gonzales to a full hearing is less worthy of consideration than the... men in Morgan."259

In his concluding remarks, the Chief Justice dwelt on the nature of fundamental liberties and the intent of congress
254 Ibid., p. 73.
255 Ibid.
256 Ibid.
257304 U.S. 1 (1938).
258Ibid., pp. 18-19.
259 Gonzales v. United States (1960), p. 74 . 
352

to respect and protect them no matter how the statutes were read:

I am unwilling to give to a statute conceived in such a context, a construction which results in a young man of unblemished reputation, who claims religious scruples, being sent to prison for 15 months without having received a FULL AND FAIR CONS IDERATION of his case. 260

In a way, Mr. Chief Justice Warren's statement seems to be a good finale to the examination of subject cases. The majority, after all, contended that there was in the instant case a "full and fair consideration," reflecting the controversial nature of all the cases involved. In nearly all of the conscientious objector cases, the constitutional issue seems to have been related -- usually quite directly -- to the compliance with this requirement. Thus the latest case, a five to four hotIy divided decision, did not alleviate greatly the difficulties which had plagued the court for years. Gonzales is an example of one of the difficulties inherent in the issue. Whereas the majority looked at the mechanics of the rules and procedures prescribed by statutes and court decisions, the minority was wont to put more emphasis on the nature of the case in the light of the character of the individual. To the minority, the majority erred in failing to respect the honesty of the petitioner as a major factor in finding whether the procedure granted was fair and just. On the other hand, the majority

$$
\text { 260 }{ }_{\text {Ibid.., p. } 75 .}
$$


353

felt it enough that the procedural requirements were met in the light of the incongruity of the registrant's statements contained in the files.. All this is not to say that the court failed to make long strides in defining and clarifying what it felt to be proper constitutional procedures to be observed in conscientious objector cases. Congress, it seems, helped to intensify the difficulty by writing into the statutes vague language. The provision that the decisions of boards shall be final, without stating what was meant by "final," is a case in point. "Constitutional lawyers in Congress ought to have been aware that such language would raise more issues than it clarified, as indeed it did."261 But through the course of years, in piecemeal fashion, the court was able to give meaning to the laws governing the activities of the conscientious objectors despite vague statutory language and redundantly vexatious demands.

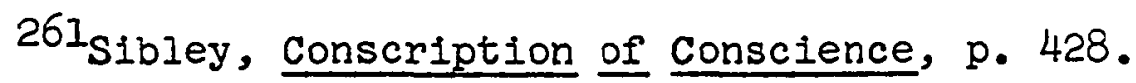


PART III

CONCLUSION

\section{CHAPTER $X$ \\ LEGALITY AND IEGACY}

It is perhaps an overstatement, but it has been said that "seldom, if ever, in the past, has one individual group been able to shape the course, over a period of time, of any phase of our vast body of constitutional law, "I as has been accomplished by a relatively small religious sect known as the Jehovah's Witnesses. That it took an unpopular group to develop a body of law for the more conventional is not only admitted, but is perhaps one of the real ways by which law itself can be made meaningful in a free society. "The beliefs of the Jehovah's Witnesses precisely because they run counter to those of the great majority, "2 have performed a constitutional service. More specifically, to the development of the scope and breadth of First Amendment freedoms, the "Jehovah's Witnesses have contributed the most."3 They were able to contribute to the "development of a constitutional law concerning First Amendment liberties [more] than any other group in history. . [because] they fought vigorously every legal attempt

IMulder, Bill of Rights Review, II, p. 262. See also walter F. Murphy and C. Herman Pritchett, Courts, Judges and Politics (New York: Random House, 1961), p. 283.

${ }^{2}$ Green, Washington University Law Quarterly, XXVII, p. 524. 3Mulder, Bill of Rights Review, II, p. 262. 
to curb their activities." 1455

In all of the cases before the court, the Witnesses fought "with fanatical zeal. . .as a result. . these declsions have done much to clarify our constitutional law relating to freedom of religion." 5 The cause and effect of this general development are relatively simple to analyze. In the attempt to apprise the peopie of impending doom and to get them to embrace the faith in which they themselves hold;

This cult has found it necessary to struggle against a tremendous surge of unfriendly local opinion and opposition -- opposition alded by local laws designed to curtall the Witnesses functions and activities -opposition aided and abetted by zealously antagonistic local law-enforcement authorities.6

In all these cases brought before the court, the difficulties were legion, but perhaps the heart of the difficulty lay in the conflict between the preservation of "fundamental state needs, "7 over and against constitutional liberties which were to be Iikewise safeguarded. In this respect, the role played by the Jehovah's Witnesses has been impressive, for the decisions resulting from their actions "now set the pattern for state courts in determining how far state legislatures may validly proceed on matters pertaining to freedom of speech

4Rocco J. Tresolini, American Constitutional Law (New York: The Macmilian Co., 1959), p. 37 .

5Robert E.Cushman, Leading Constitutional Decisions (New York: Appleton-Century-Croits Inc., 1960), p. 132.

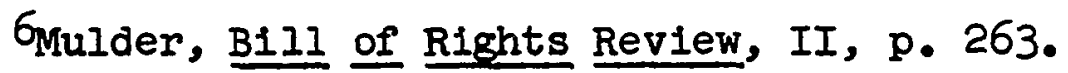

7 Ibid., p. 305. 
and religion." 8 The cases increased in number and assumed greater significance, as local legislative bodies, by employing new and different devices, sought to overcome the laws ruled unconstitutional by the court. "Thus, while the cult - .has negligible influence, its incidental contributions to constitutional law have been tremendously significant."9

The Supreme Court has never considered challenging legislation as part of its primary task, indeed, not even a secondary responsibility. But, in the words of Justice Murphy in his dissenting opinion in Opelika:

Where regulation or infringement of the liberty of discussion and the dissemination of information and opinion are involved, there are special reasons for testing the challenged statute. . .10

But even when such an occasion is at hand, the Court's responsibility demands the exercise of reasonable restraint. This is what Frankfurter meant when he said, "But to the legislature no less than to courts is committed the guardianship of cherished Iiberties."Il when a conflict occurs between authority and

8Mulder ard Comisky, Bill of Rights Review, p. 263. 9Ibid.

I0Jones v. Opelika, p. 615. Murphy here relied chiefly on the decisions rendered in Thornhill v. Alabama, Lovell v. Griffin, supra, and Drivers Unionv. Meadowmoor Company, 312 U.S. 287 (194I).

11Minersville School District v. Gobitis, p. 600 . 
liberty, "we are not the primary resolver of the clash." 12 Who then is? Precisely because the question cannot be satisfactorily answered, the whole judicial process has required the search for an adjustment. In the stream of constitutional development, the existence of certain rules and principles has not resolved all conflicts. "The indefatigable exertions by Jehovah's Witnesses"13 have forced the court to seek "a serviceable rule for drawing the line. - In its search for a proper adjustment between conflicting claims to freedom in the exercise of religion." 14

Most of the earlier cases brought before the courts involved the police powers of the state as against the claims of the right of individuals to speak and publish without restraint. Involved here was the principle that "the aim of [free] society is its own common good, "I5 which the court itself has been willing to respect. But the "common good," or "public interest," has not always been distinguishable when a personal freedom became a constitutional obstruction. Thus, in piecemeal fashion the court dealt with each case as it was

12Letter from Frankfurter to Stone. Quoted in Mason, The Supreme Court from Taft to Warren, p. 139 .

13Edward Dumbauld, The Bill of Rights and what it Means Today (Norman: University of Oklahoma Press, 1957), p. I13.

14 Arthur N. Holcombe, Our Mare Perfect Union (Cambridge: Harvard University Press, 1950), p. 381.

15Jaques Maritain, The Rights of Man and Natural Law (Glasgow: GIasgow University Press, 1958), p. 8 . 
presented. In time, a rule, faint as it may have been, was developed. As an example, in the distribution of handbills and other religious literature, the Court put great weight on the freedoms of speech and press and held that the police power of the state to keep the streets clean or to protect its citizens from being unduly "bothered" by knock on doors and ringing of doorbells, was insufficient to restrict the activity. 16 On the other hand, the police power of the state was sufficient to restrict the activity of minors when they were engaged in handbill distribution in the public streets.17 The court, in this instance was willing to assume that the protection of the health and welfare of minors was so jeopardized by strenuous physical activities that it outbalanced the import and weight accorded religious freedom.

The use of public parks too has been declared to be free and available generally without the requirement of a permit. 18 Especially offensive is the permit, if it is used to discriminate against certain groups. 19 But if the granting of permits is left in the hands of officials with no discretion, no power

16 Lovell v. Griffin, Schneider v. Irvington, Largent $v$. Texas, Jamison $v$. Texas, and Martin v. Struthers, supra.

17 Prince v. Massachusetts, supra.

18 Niemotko v. Maryland, supra.

19Fowler V. Rhode Island, supra. 
359

to discriminate or to control free speech, only to assure reasonable comfort and convenience of the whole city, the Court has permitted such ordinances to stand. 20 when it concerns the use of public streets for the purpose of conducting parades and demonstrations, the police power of the state is almost absolute. Obviously, personal freedom cannot be granted if it interfered with the orderliness of city traffic and the convenience of "26,000 persons." The safety and convenience of the people in the use of public highways loom large in this instance, and ordinances passed to safeguard them, have never been regarded as inconsistent with civil liberties. 21

No matter how unpleasant the language or how disturbing mechanically amplified sound may be, the court has upheld the right to their use in public places. 22 Thus the use of record players and public address systems has been defined as a part of free speech guarantees. But unpleasant language has a limitation, namely, that it must not constitute "fighting words."23 Here, the Court will impose the "clear and present danger" rule. If the speech in question will incite a riot or create a danger to the public, then this is one of

$$
\begin{aligned}
& 20 \text { Poulos v. New Hampshire, supra. } \\
& { }^{21} \text { Cox v. New Hampshire, supra. } \\
& \text { 22Cantwell v. Connecticut, Saia v. New York, supra. } \\
& \text { 23Chaplinsky v. New Hampshire, supra. }
\end{aligned}
$$


the "substantive evils that Congress has a right to prevent." 24 The test of a "bad" word as provided in Chaplinsky, was whether the word in question is "likely to provoke the average person to retaliation."25 And the epithet, "damned racketeer," or "damned fascist," would provoke any average person to retaliate, thereby causing a breach of peace which the state has the power to prevent. As the court reiterated over and over, freedom of speech is not absolute. And in saying so, the court pronounced the difficulty with which all democratic systems have been afficted.

In the license tax cases, the court at first permitted state imposition of nondiscriminatory taxes on the ground that selling literature however small the fee, or whatever type the material, was not an unconstitutional infringement of First Amendment freedoms.26 Within a short time however, the court reversed itself and held unconstitutional state ordinances requiring license fees upon pedalers of religious literature. 27 According to the Court, the colporteur's activity was not transformed into a commercial enterprise merely because he "sold" his articles rather than "donated" them. This was an unconstitutional flat tax. In this development, the court

${ }^{4}$ Schenck v. United States, supra.

25 Chaplinsky v. New Hampshire, p. 574.

26Jones v. Opelika, supra.

27 Murdock v. Pennsylvania, supra. 
361

pointed out that the proper place for attack against state licensing ordinances was not on the federal court level, but through state courts. 28 The restriction against licensing ordinances was likewise applicable to the District of Columbia, 29 and it made no difference whether the colporteur was an itinerant evangelist, or a resident minister, the law was equally availing. 30

In many ways similar to the Iicense tax cases, in the flag salute controversy, the Court reversed itself from an earlier decision which upheld a state action to require public school children to salute the flag. 31 Although the Court at first reasoned that to the legislative bodies belongs the responsibility to determine proper modes of inculcating into young minds certain desirable behavior, it abandoned this reasoning a rew years later on the ground that compulsory flag salute was tantamount to compulsory allegiance to a belief which the First Amendment forbade. 32 To demand the expression of a belief against a person's will was an unconstitutional command. Neither were the states permitted to restrain Jehovah's Witnesses from distributing literature explaining why they were

28 Douglas v. City of Jeannette, supra.

29Busey v. District of Columbia, supra.

30 Follett v. McCormick, supra.

3lMinersville School District v. Gobitis, supra.

32 West Virginia Board of Education v. Barnette, supra. 
opposed to the compulsory flag salute. 33

When the validity of restrictions upon distribution of religious literature is under consideration, there is no difference between a "company town" whether privately-owned34 or government-owned, 35 from an ordinary community. They will be treated alike. Thus if a municipality cannot prohibit peddlers of religious literature from distributing their ware in its own township, under similar conditions, neither can a company town impose the same restriction.

In the conscientious objector cases, the Court established some basic procedural rules. Most important, judicial review would not be available until the whole administrative process was exhausted.36 The registrant was not required to report to camp in order to exhaust the procedural remedies: He could make a defense as to the validity of the classification before induction. After induction, his only remedy would be through a writ of habeas corpus, unless it was a Civilian Public Service camp in which case, the normal civil channels of judicial reliefs were still open. 37 All board decisions were

33 ${ }_{\text {Taylor }} v$ Mississippi, and Mathews vo Hamilton, supra. 34Marsh v. Alabama, supra.

35 Tucker v. Texas, supra.

36Falbo v. United States, supra.

37 Gibson v. United States, supra. 
final, even when the decisions were made erro. cously. 38 Furthermore, if a registrant failed to make an appeal, he could not later do so by claiming that his fa?-ure was based on the ground that appeal at that time would have been futile.39 The proper place to hold a trial for the registrant who was indicted for failure to report for woik, was in the vicinage of the crime, that is, in the place where he was required to report for work, not in the district where he resided. 40

The determination as to whether a registrant is to be classified a minister or a conscientious objector was a question of law for determination by the court, 41 but the burden of such proof lay with the registrant, and the board could act only upon the objective facts in the case. 42 on the other hand, when the registrant objected to participation in war on religious grounds, the board could use sincerity as a test and not objective facts alone. There must be reasonable consistency in the registrant's claims. 43

The Universal Military Training and Service Act, among other requirements, compelled the Department of Justice to

38 Estep v. United States, supra.

39sunal v. Large, supra.

40Johnston v. United States, Supra.

${ }^{41}$ Cox v. United States, supra.

42Dickinson v. United States, supra.

43witmer v. United States, and Sicurella v. United States, supra. 
furnish the registrant with a "fair resumé" of FBI reports and the opportunity for rebuttal. 44 Although the Act did not expressly provide that the registrant be supplied with the Department's recommendations to the board, this too, the court said must be furnished the registrant. 45 conversely, due process was not denied, and the requirement of the Act was met if the registrant had access to his files in which the proper information was contained. It was not necessary that the registrant be supplied a copy of the hearing officer's report, or be given the opportunity to inspect the original FBI reports. A resumé of the report was sufficient to meet the provision of the Act. 46

In all this, the court was cognizant of the fact that Congress carefully outlined the procedure for induction even providing for a step by step appeal system. "Except where the Constitution requires it, judicial review of administrative action may be granted or witheld as congress chooses, "47 otherwise there would occur "Iitigious interruption" which" Congress intended to prevent. The boards were therefore granted great leeway in classifying the registrants. Presumption was

${ }^{44}$ Simmons v. United States, Bates v. United States, Simon v. United States, and De Moss v. United States, supra. 45 Johnston v. United States, supra. $46_{\text {Gonzales }}$ v. United States, (1960), supra. 47 Estep v. United States, supra. 
in their favor, and unless their decisions had no basis in fact, or were wantonly arbitrary and capricious, they were left to stand.

Historically, whenever the Court has faced a recurrent issue the substance of which was not easily distinguishable in relation to constitutional principles, the result has been the search for a standard. To a large measure, this is an important function of the Court. Although the Constitution is couched in general terms, it has not prevented implementing standards, for the Court has been fairly successful in fashioning guidelines. Some of the more enduring are; the "clear and present danger" rule, the "reasonable man" theory, and the "secular regulation" rule. To be sure, these rules are not absolute, nor will there ever be one. But they have served to circumscribe the bounds beyond which certain activities will not be allowed. The difficulty in the cases brought before the Court by the Jehovah's Witnesses has been pronounced because none of these rules was sufficient in itself except in some isolated instances. Frequently a combination of criteria was applied. Treated as a whole, the problem was in the attempt to shape a policy in the light of the difficulties ingrained in any claim based upon religlon against the will of authority.

It is not submitted here that the court is a policymaking body. The answer to that problem lies in a proper definition of policy-making. It is submitted however, that the 
366

Constitution does not interpret itself, and if the action of the Court overlaps into an area reserved to other organs of the system, this too is a matter of interpretation. The discrepancy -- if it can be called that -- is not in the action of the court, it is inherent in a system of idealistic separation, a separation which in its ideal form, is not to be had. Because the Constitution does not interpret itself the cases examined in this study reveal that in matters where the proper application of the Constitution was unknown, or at bests nebulous, the Court acted as the lawgiver. And give law, it did. But what did the Jehovah's Witnesses give?

The contribution of the Jehovah's Witnesses to American constitutional law is monumental within the bounds of basic fundamental liberties. In most cases their activities did not make primary contributions; at best, they were secondary. This is not to minimize the significance of their impact in constitutional development. As far as religious groups are concerned, more than any other single denomination or sect, the Jehovah's Witnesses unquestionably made the greatest contribution toward the clarification and implementation of constitutional guarantees. This alone, is a distinction worthy of honor and note. As a single religious group, not only were they responsible for the greatest number of court cases, they were able, in most instances, to realize their demands far beyond the expectation of the majority in general. In other words, in addition to numerical superiority, there was the important aspect of 
367

qualitative achievement. As has been said, "Even when the Jehovah's Witnesses lose a case in the Supreme Court they seem able to lose in such a way as to make another contribution to building the legal structure of civil liberty. " 48

With respect to important constitutional advances, of a primary nature was the contribution made toward the definition of fundamental liberties especially in freedom of religion as it is related to other freedoms such as speech and assembly. This is an outstanding characteristic of the Jehovah's Witnesses cases. Very seldom, if ever, was the constitutional question dependent upon a single freedom, it was more a fusion of basic rights, the flag salute cases notwithstanding.

The flag salute cases serve as an example of a contribution of a primary nature. This recurrent issue compelled the Court to render a judgment as to what the Constitution required, when a citizen refused to salute a national symbol -- never before legally questioned -- on the basis of his religious beliefs. This was more than just a requirement to make outward obeisance

48" Jehovah's Witnesses Lose -- and Win, "Christian Century, IXX (May 13, 1953), p. 565. The reasoning of this argument was based on Poulos v. New Hampshire, 345 U.S. (1953), in which the court held that the portsmouth authorities had no right to deny the Jehovah's Witnesses a permit to conduct religlous meetings in a public park, but upheld the fine imposed on the petitioner on the ground that the proper remedy was a writ of mandamus. "So that, in upholding the fine, the Court at the same time laid down a sweeping rule covering the relation of local ordinances to the guarantees of the First Amendment." 


\section{8}

to a badge of national unity, it was a liberal interpretation of constitutional guarantees and a long stride in the direction of expanded preferred freedoms. It was a constitutional interpretation of staggering proportions which was not contingent on religious freedom alone although the contention itself had been so based. So fundamental a practice as the expression of allegiance to a country's highest symbol was relegated to a "back seat" when the issue involved compulsion. Yet the authority of any effective, well-ordered state to exercise compulsion has never been questioned.

The Iicense tax cases too, emphasized this important trend. At this point, there occured a great shift in the development of constitutional law relating to license taxes. It took the Jehovah's Witnesses to bring about the doctrine that the dissemination of religious ideas was not subject to license fees even if the ideas were expressed through the channels and methods long thought to be commercial, and therefore taxable. The question became one of when and tc whom may the state impose a tax -- really an age-old problem. But the tax was declared invalid even when it appeared to be nondiscriminatory and was reasonably imposed for the purpose of defraying expenses incurred by those being taxed. Of great significance is the fact that previously, license taxes on publications and other forms of expression were held to be valid on the ground that the tax was not on the expression, but on the methods 
utilized. What makes the Jehovah's Witnesser, cases momentous is the fact that the constitutional argument of the validity of taxation on publications and distribution is still good law, but is unavailing when applied to distribution of religious literature. This of course opens up great avenues in constitutional law relating to license fees on dissemination of ideas. The issues involved herein are far from complete. The criticisms as to why the press is not accorded similar privileges have been discussed (see chapter VI). These cases seem to say that the dissemination of religious ideas is not the same as disseminating other ideas. It is still an academic question inasmuch as other ideas such as those expressed through political handbills are usually distributed free of charge. It was to this general expansion of religious liberties $\mathrm{Mr}$. Curtis made reference when he said, "transcendental abstractions have a way of getting absurd," and that was because some justices found themselves in the "transcendental ditch." 49 Reasonable or absurd, the decisions were a landmark if only they served to open up new constitutional doors and judicial vistas.

The constitutional contribution in the specific areas of speech, assembly and press are also notable, but the trends, established by previous cases loom so large in the background, that the Jehovah's Witnesses cases -- at best -- served only

49Charles P. Curtis Jr. Lions Under the Throne (Boston: Hought on Mifflin Co., 1947), pp. $\frac{21313-314 .}{3 .}$ 
to strengthen or verify earlier judicial interpretations. As for example: in the Boston common case, 50 the court upheld the power of the legislature to restrict the use of a public place on the ridiculous reasoning that since the legislature had the power to put an end to the use of a public place, "it may take the lesser step of limiting the public use.. "5l The Jehovah's witnesses could have made a primary contribution here, had it not been for Hague v. C.I.0.52 which overshadowed all free speech cases involving the Witnesses. Near v. Minnesota 53 too sapped some of the constitutional strength from the Jehovah's Witnesses cases affecting the issue of prior censorship in free speech. This is not to say that the Witnesses' contribution in this particular area is nil, it does substantiate however, the claim that the contribution was not as momentous as in some other areas. But it is false modesty that disclaims significance merely because the contribution has not been primary. If Hague established a fundamental principle, then It took the Jehovah's Witnesses to evaluate and amplify the most pertinent aspects of its constitutional implications. This it seems is a signal contribution of the witnesses in practically every area within which they were involved. It

50 Davis v. Massachusetts, 167 U.S. 43 (1897).

5l Ibid., p. 47.

52307 U.S. 496 (1939).

53283 U.S. 697 (1931). 
371

was not their lot to be blessed with many constitutionally unimportant cases.

No less important are the numerous occasions which drove the court to define, in constitutional terms, what was meant by the incorporation of religious freedom into the due process clause of the Fourteenth Amendment. To be sure, the doctrine was not novel with the witnesses, but it took this wayward religious pressure group to goad the court to action from which have emerged intelligible constitutional language and realistic administrative principles. The Jehovah's Witnesses never settled for constitutional platitudes.

Whether it be the use of sound devices in public gatherings, conscientious objection to national service, or ringing doorbells in a "peace-loving" neighborhood, one thing has been made clear; in the development of constitutional trends within a complex community of industrial progress and materialistic wealth, the Jehovah's Witnesses made a noticeable mark in preserving the basal right of an individual to believe and pursue the dictates of his conscience even when the odds are overwhelmingly against the attainment of his pursuits. In a society where the trend in recent years has been to look upon the individual as a part of the mass, and to treat him within the context of an impersonal assemblage, the Jehovah's Witnesses spelled out the constitutional meaning of the individual and his personal rights, and the extent to which he may pursue them before the constitutional wall itself became the barrier. 
372

In making this mark in the development of law, the witnesses did so without sacrificing greatly the police powers of the state. On the surface, it often appeared that the authority of the state to invoke its power of police was being hampered and restricted by the incessant importunities effected by this indomitable sect, but hindsight surveillance indicates otherwise. The Jehovah's Witnesses performed the great service of determining "how far religious liberty may be tolerated before it becomes limitable license under the police power." 54 In other words, police powers too are subject to limitations, and the Witnesses helped to circumscribe their judicial limitations. This service too was not novel, but within the sphere of parades, meetings, and solicitation in the public arena, the establishment of judicial opinions relating to the proper scope of police powers is manifestly a service of the Jebovah's Witnesses.

In the mainstream of constitutional development, there are often more complicated and lesser streams which flow without distinguishable direction. A landmark development such as that made by Gitlow, Hague, or Gobitis, may be considered the beginning of a mainstream or the heart of the stream itself. But the fusion with the mainstream of these lesser streams is a momentous contribution to the development of an intelligible trend. Constitutional trends are not the result of any one case, they depend upon a series of related cases. It is this service

54Barber, A.P.S.R., XII, p. 228. 
373

of developing trends in the area of speech, press, assembly and especially religion, the Jehovah's Witnesses are without equals. They aided greatly in channeling into the vast constitutional stream of fundamental freedoms the relationship of these basic exercises in the framework of liberty and authority • 
Chapter III Solicitation and State Ordinances

Lovell v. Griffin, 303 U.S. 444 (1938).

Schneider vo New Jersey, 308 U.S. 147 (1939).

Largent v. Texas, 318 U.S. 413 (1943)。

Jamison v. Texas, 318 U.S. 413 (1943).

Martin v. Struthers, 319 U.S. 141 (1943).

Prince v. Massachusetts, 321 U.S. 158 (1944).

Chapter IV Permits, Parks, and Parades

Niemotko v. Maryland, 340 U.S. 268 (1951).

Fowler v. Rhode Island, 345 U.S. 57 (1953).

poulos V. New Hampshire, 345 U.S. 395 (1953).

Cox v. New Hampshire, 312 U.S. 569 (1941).

Chapter V Sound Devices and "Fighting Words"

CantweII v. Connecticut, 310 U.S. 296 (1940).

Saia v. New York, 334 U.S. 558 (1948).

Chaplinsty v. New Hampshire, 315 U.S. 568 (1942).

Chapter VI Life, Liberty, and License Taxes

Jones v. Opelika, 316 U.S. 584 (1942).

Murdock v. Pennsylvania, 319 U.S. 105 (1943).

Douglas v. Jeannette, 319 U.S. 157 (1943).

Busey v. District of Columbia, 319 U.S. 579 (1943).

Follett v. McCormick, 321 U.S. 573 (1944)。

Chapter VII "Thou Shalt Not Give Allegiance"

Minersville School District v. Gobitis, 310 U.S. 586 (1940).

Taylor v. Mississipp1, 319 U.S. 583 (1943). West Virginia State Board of Education v. Barnette, 319 $624(1943)$.

Mathews v. Hamilton, 320 U.S. 707 (1943).

Chapter VIII Peddling v. Private Property

Marsh v. Alabama, 326 U.S. 501 (1946).

Tucker v. Texas, 326 U.S. 517 (1946).

Chapter IX Conscription and Conscience

Falbo v. United States, 320 U.S. 549 (1944).

Estep v United States, Smith v. United States, 327 U.S. $\Pi 14(1946)$.

Dodez v. United States, Gibson v. United States, 329 U.S. 338 (1946).

Alexander v. Kulick, Sunal v. Large, 332 U.S. 174 (1947).

Cox v. United States, 332 U.S. 442 (1947).

Dickinson v. United States, 348 U.S. 389 (1953). 
375

Gonzales v. United States, 348 U.S. 407 (1955). Witmer v. United States, 348 U.S. 375 (1955). Sicurelia v. United States, 348 U.S. 385 (1955). Simmons v. United States, 348 U.S. 397 (1955). Bates v. United States, 348 U.S.966 (1955). Simon v. United States, 348 U.S. 967 1955). De Moss v. United States, 349 U.S. 918 (1955). Patteson v. United States, 351 U.S. 215 (1956). Johnston v. United States, 351 U.S. 215 (1956): Gonzales v. United States, 364 U.S. 59 (1960). 
TABLE 2

\section{STATUTORY DEFINITION OF MINISTER}

50 U.S. CODE APP. SEC. 456

(8) Regular or duly ordained ministers of religion, as defined in this title [Sections $451--454$ and $455--471$ of this Appendix 7 , and students preparing for the ministry under the direction of recognized churches or religious organizations, who are satisfactorily pursuing full-time courses of instruction leading to their entrance into recognized theological or divinity schools in which they have been preenrolled, shall be exempt from training and service (but not from registration) under this title [said sections].

Section 16 (g) (1) The term "duly ordained minister of religion" means a person who has been ordained, in accordance with the ceremonial, ritual, or discipline of a church, religious sect, or organization established on the basis of a community of faith and belief, doctrines and practices of a religious character, to preach and to teach the doctrines of such church, sect, or organization and to administer the rites and ceremonies there of in public worship, and who as his regular and customary vocation preaches and teaches the principles of religion and administers the ordinances of public worship as embodied in the creed or principles of such church, sect, or organization.

(2) The term "regular minister of religion" means one who as his customary vocation preaches and teaches the principles or religion of a church, a religious sect, or organization of which he is a member, without having been formally ordained as a minister of religion, and who is recognized by such church, sect, or organization as a regular minister.

(3) The term "regular or ordained minister of religion" does not include a person who irregularly or incidentally preaches and teaches the principles of religion of a church, religious sect, or organization and does not include any person who may have been duly ordained a minister in accordance with the ceremonial, rite, or discipline of a church, religious sect or organization, but who does not regularly, as a vocation, teach and preach the principles of religion and administer the ordinances of public worship as embodied in the creed or principles of his church, sect, or organization. 
TABLE 3

STATUTORY PROVISION RELATING TO CONSCIENTIOUS OBJECTION

50 U.S. CODE APP.SEC. 456

(j) Nothing contained in this title SSections $451--454$
and $455--471$ of this Appendix 7 shall be construed to require any person to be subject to combatant training and service in the armed forces of the United States who, by reason of religious training and belief, is conscientiously opposed to participation in war in any form. 


\section{BIBLIOGRA PHY}

CASES

Adamson v. California, 332 U.S. 46 (1947).

Adkins v. Children's Hospital, 261 U.S. 525 (1923)。

Alexander v. Kulick, 332 U.S. 174 (1947).

American Toll Bridge Co. v Railroad Commission of California et. aI., 307 U.S. 486 (1939).

Balley v. Drexel Furniture Co., 259 U.S. 20 (1922).

Bates v. United States, 348 U.S. 966 (1955).

Barkus V. Illinois, 359 U.S. 121 (1959).

Beal v. Missouri Pacific Ry. Corp., 312 U.S. 45 (1941).

Beauharnais V. Illinois, 343 U.S. 250 (I952).

Berman v. United States, 156 F 2d 377 (1946).

Billings v. Truesdale, 321 U.S. 542 (1944).

Bridges v. California, 314 U.S. 252 (1941).

Buchanan v. Warley, 245 U.S. 60 (1917).

Bunting v. Oregon, 243 U.S. 426 (1917).

Busey v. District of Columbia, 319 U.S. 579 (1943).

Cantwell v. Connecticut, 310 U.S. 396 (1940).

Chaplinsky v. New Hampshire, 315 U.S. 568 (1942).

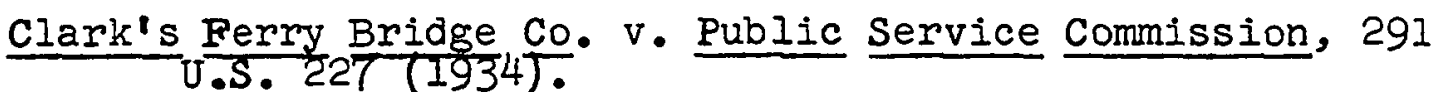

Cox v. New Hampshire, 312 U.S. 569 (1941).

Cox v. United States, 332 U.S. 442 (1947).

Craig v. Harney, 331 U.S. 367 (1947).

Davidson v. New Orleans, 96 U.S. 97 (1878).

Davis v. Massachusetts, 167 U.S. 43 (1897). 
De Jonge v. Oregon, 299 U.S. 353 (1937). Dennis v. United States, 339 U.S. 162 (1950).

De Moss v. United States, 349 U.S. 918 (1955).

Dickinson v. United States, 348 U.S. 389 (1953).

Dodez v. United States, 329 U.S. 338 (1946).

Douglas v. Jeannette, 319 U.S. 157 (1943).

Drivers Union v. Meadowmoor Co., 312 U.S. 287 (1941).

Estep v. United States, 327 U.S. 114 (1946).

Everson v. Board of Education, 330 U.S. 1 (1947).

Plabo v. United States, 320 U.S. 549 (1944)。

Feiner v. New York, 340 U.S. 315 (1951).

Fiske v. Kansas, 274 U.S. 380 (1937).

Flakowicz v. United States, 325 U.S. 851 (1945).

Follett v. McCormick, 321 U.S. 573 (1944).

Fowler v. Rhode Island, 345 U.S. 57 (1953).

Gabrielli v. Knickerbocker, 396 U.S. 621 (1939).

Giboney v. Empire Storage and Ice Co., 336 U.S. 490 (1949).

Gitlow v. New York, 268 U.S. 652 (1925).

Gonzales v. United States 348 U.S. 407 (1955).

Gonzales v. United States, 364 U.S. 59 (1960)。

Graves v. Minnesota, 272 U.S. 425 (1926).

Grosjean v. American Press Co., 297 U.S. 233 (1936).

Hague V. C.I.O., 307 U.S. 496 (1939).

Halter v. Nebraska, 205 U.S. 34 (1907).

Hamilton v. Board of Regents of University of California, 293 U.S. $245(1934)$.

Hammer v. Dagenhart, 247 U.S. 251 (1918). 
380

Hering v. Board of Education, 303 U.S. 624 (1938).

Herndon v. Lowery, 301 U.S. 242 ( $\overline{1} 937$ ).

I.C.C. v. Louisville and Northern Ry. Co., 227 U.S. 88 (1913). Jackson, ex parte, 96 U.S. 727 (1778).

Jamison v. Texas, 318 U.s. 413 (1943).

Johnson v. Deerfelo, 306 U.S. 621 (1939).

Johnston v. United States, 351 U.S. 215 (1956).

Jones V. Opelika, 316 U.S. 584 (1942).

Kovacs v. Cooper, 336 U.S. 77 (1949).

Kunz v. New Yorkx, 340 U.S. 290 (1951).

Largent v. Texas, 318 U.S. 413 (1943).

Leoles v. Landers, 302 U.S. 656 (1937).

Lochner v. New York, 109 U.S. 45 (1905).

Lovell v. Griffin, 303 U.S. 444 (1938).

Marsh v. Alabama, 326 U.S. 501 (1946).

Martin v. Struthers, 319 U.S. 141 (1943).

Masses Publishing Co., v. Patten, 244 Fed. 535 (1917).

Mathews v. Hamilton, 320 U.S. 707 (1943).

McCray v. United States, 195 U.S. 27 (1904).

McCulloch v. Maryland, 4 Wheaton 316 (1819).

McCulloch v. Board of Education, 333 U.S. 203 (1948).

Meyer v. Nebraska, 262 U.S. 390 (1923).

Miller v. Schoene, 276 U.S. 272 (1928).

Minersville School District v. Gobitis, 310 U.S. 851 (1940).

Muller v. Oregen, 208 U.S. 412 (1908).

Munn v. IIlinols, 94 U.S. 113 (1877). 
Murdock v. Pennsylvania, 319 U.S. 105 (1943).

Nashville Coal and St. Louis Ry. v. Walters, 294 U.S. 405

National Labor Relations Board v. Jones and Laughlin Steel Corp. 301 U.S. I (1937).

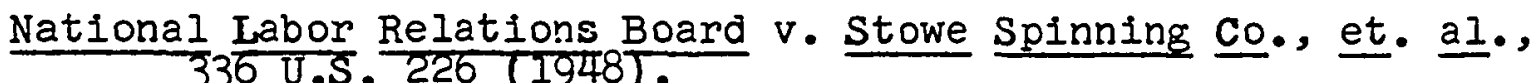

Near v. Minnesota, 283 U.S. 697 (1931)。

Nebbia v. New York, 291 U.S. 502 (1934).

Niemotko v. Maryland, 340 U.S. 268 (1951).

Norfolk and Southern Turnpike Co., v. Virginia, 225 U.S. 265 (1912).

Northeast Fertilizing Co. v. Hyde Park, 97 U.S. 659 (1878).

Ohio Bell Telephone co. v. Public Utilities Commission, 301 U.S. 292 (1937).

Olsen v. Nebraska, 313 U.S. 236 (1941).

Panhandle Eastern Pipeline Co. V. Highway Commission, 294 U.S. 613 (1935).

Panhandle Oil Co. v. Knox, 277 U.S. 218 (1928).

Palko v. Connecticut; 302 U.S. 319 (1937).

Patterson v. Colorado, 205 U.S. 454 (1907).

Patteson v. United S.tates, 351 U.S. 215 (1956).

Pennecamp v. Florlda, 328 U.S. 331 (1946).

Pierce v. Society of Sisters, 268 U.S. 510 (1925).

Pierce v. United States, 252 U.S. 239 (1920).

Port Rlchmond Ferry v. Hudson County, 234 U.S. 317 (1914)。

Pouios v. New Hampshire, 345 U.S. 395 (1953).

Prince v. Massachusetts, 321 U.S. 158 (1944).

Prudential Insurance Co. v. Cheek, 250 U.S. 530 (1922). 
Republic Aviation Corp. V. National Labor Relations Board, 435 U.S. 793 (1945).

Reynolds v. United States, 98 U.S. 145 (1879).

Rinko v. United States, 325 U.S. 851 (1945).

Roth v. United States, 354 U.S. 476 (1957).

Rumely v. McCarthy, 250 U.S. 283 (1913).

Saia v. New York, 334 U.S. 558 (1948).

Schenck v. United States, 249 U.S. 366 (1918).

Schneider v. New Jersey, 308 U.S. 147 (1939).

Selective Draft Law Cases, 245 U.S. 366 (1918).

Sicurella v. United States, 348 U.S. 385 (1955).

Simmons v. United States, 348 U.S. 397 (1955).

Simon v. United States, 348 U.S. 967 (1955).

Slaughterhouse Cases, 16 wall 36 (1873).

Smith v. Cahoon, 283 U.S. 553 (1931).

Spiliman Motor Co. v. Dodge, 295 U.S. 89 (1935).

Taylor v. Mississippi, 319 U.S. 583 (1943).

Terminiello v. Chicago, 337 U.S. 1 (1949).

Terrace v. Thompson, 263 U.S. 197 (1923)。

Thomas v. Collins, 323 U.S. 516 (1945)。

Thornhill v. Alabama, 310 U.S. 88 (1940).

Tucker v. Texas, 326 U.S. 517 (1946).

United States v. Abilene and Southern Ry. Co., 265 U.S. 274

United States v. Anderson, 328 U.S. 699 (1946).

United States v. Ballard, 322 U.S. 78 (1944).

United States ex. rel. Brandon v. Downer, 139 F 2d 761 (1944). 
383

United States v. Butler, 297 U.S. 1 (1936).

United States v. Carolene Products Co., 304 U.S. 144 (1938).

United States v. Kauten, 133 F 2d 703 (1943).

United States.v. Lombardo, 241 U.S. 73 (1916).

United States v. MacIntosh, 283 U.S. 605 (1931).

United States ex. rel. Phillips v. Downer. $135 \mathrm{~F} 20521$ (1943).

United States ex. rel. Reel v. Badt, $141 \mathrm{~F}$ 2d 845 (1945).

Veazie Bank v. Fenno, 8 Wall 533 (1869).

Watson v. Buck, 313 U.S. 387 (191.3).

West Coast Hotel Co. v. Parrish, 300 U.S. 379 (1937).

West Virginia Board of Education v. Barnette, 319 U.S. 624 (1943).

Whitney v. California, 274 U.S. 357 (1927).

Williams v. Miller, 317 U.S. 599 (1942).

Witmer v. United States, 348 U.S. 375 (1955).

Yakus v. United States, 321 U.S. 414 (1944).

Zorach v. Clauson, 343 U.S. 306 (1952).

Articies and Periodicals

"About-Face to Freedom," New Republic, CVIII (May 24, 1943). pp. 693-694.

Albrecht-Carrie. Scientific Monthly, LXXIII (July, 1951), p. 16.

"Another Jehovah's Hitnesses Case," Indiana Law Journal, XVII (August, 1942), pp. 555-560.

Aull, William. "Freedom of Speech and Press -- Handbill Ordinances," Missouri Law Review, VI (January, 1941), pp. $103-106$.

Barber, Hollis A. "Religious Liberty v. Police Power: Jehovah's Witnesses," A.P.S.R., XII (April, 1947), pp. 266247.

Barry, Vincent J. "Statute Requiring Permit for Parade on Public Streets," Boston University Law Review, XXI (June, 1941), pp. 540-543. 
384

Beatty, Jerome. "Peddlers of Paradise," American Magazine. (Nov., 1940), pp. 53-54, 69-71.

Beth, Loren P. "Toward a Niodern American Theory of ChurchState Relationships," Political Science Quarterly, IXX. (Dec., 1955), pp. 573-597. "Bias Charged in Firings," Business Week. (Dec., 26, 1942),
p.62.

Blackman, A.J. "Freedom of Expression -- Administrative Licensing -- Breaches of Peace," Southern California Law Review, XIV (Nov., 1940), pp. 76-78.

Bowden, Witt. "Freedom for the Wage Earners," Annals, CC (Nov. 1938), pp. 185-209.

Chase, Harold W. et. al. "Catholics on the Court," New Republic, CILIII (Sept., 1960), pp. 13-15.

Christian Century, LVII (June 19, 1940), p. 792.

"Civil Liberties -- Enforcement of Peddler's Licensing Ordinance Against Members of Religious Sect Engaged in Distribution of Pamphlets," Loyola Law Review, I (June, 1942), pp. $228-230$.

"Civil Rights and Property," New Republic, CXIV (Jan. 21, 1946), p. 69.

Clark, Herbert w. "Reasoning of Mr. Justice Frankfurter in Interpreting the Constitution," The State Bar Journal of the state Bar of California, XVI (Dec., 1941), pp. $371-373$.

Cleveland Plain Dealer, Dec., 9, 1951.

"Constitutional Law," Incliana Law Journal, XVIII (JuIy, 1943), pp. 314-315.

"Constitutionality of an Ordinance Requiring People Disseminating and Selling Religious Pamphlets to Pay a License Fee," University of Pennsylvania Law Review, XCI (Aug., 1942), pp. 75-76.

Cushman, Robert E. "Constitutional Law in 1939-1940," A.P.S.R., XXXV (April, 1941), pp. 250-283.

, "Constitutional Law in 1940-1941," A.P.S.R., XXXVI (April, 1942), pp. 263-289. 
"Constitutional Law in 1941-1942," A.․․․․․‥, XXXVII (April, 1943), pp. 263-289.

"Constitutional Law in 1942-1943," A. $\underline{\text { P.S. }} \cdot \underline{R_{0}}$, XXXVIII (April, 1944), pp. 266-288.

"Constitutional Law in 1943-1944," A. $\underline{P} \cdot \underline{S} . \underline{R}$., XXXIX (April, 1945), pp. 293-308.

"Constitutional Law in 1945-1946," A. $\underline{\text { P.S. }}$. $\underline{\text { R., XII }}$ (Apri1, 1947), pp. 248-270.

"Constitutional Law in 1946-1947," $\underline{A} \cdot \underline{\underline{P}} \cdot \underline{\underline{S}} \cdot \underline{\mathrm{R}}$. , XLII (June, 1948), pp. 469-485.

Dillard Irving. "Salute to the Supreme Court," New Republic, CVIII (March 1, 1943), pp. 276-277.

"Due Process -- Freedom of Expression in Noncommercial Publications," Michigan Law Review, XII (Oct., 1942), pp. 323325.

Edmonton Journal (Alberta, Canada), Aug. 7, 1945.

Fellman, David. "Constitutional Law in 1947-1948," $\underline{A} \cdot \underline{P} . \underline{S} . \underline{R}$. , XIIII (April, 1949), pp. 275-308.

"Constitutional Law in 1950-1951," $\underline{A} \cdot \underline{P} \cdot \underline{S} \cdot \underline{R} .$, XLVI (March, 1952), pp. 158-199.

"Constitutional Law in 1952-1953," A. $. \underline{P} \cdot \underline{S} . \underline{R} .$, XLVIII (March, 1954), pp. 63-113.

"Constitutional Law in 1953-1954," $\underline{A} \cdot \underline{P} \cdot \underline{\underline{S}} \cdot \underline{\mathrm{R}} \cdot$, XIIX (March, 1955), pp. 63-106.

"Constitutional Law in 1955-1956," …․․․․…, LI (March, 1957), pp. 158-196.

"Constitutional Law in 1957-1958," ‥P.․․․‥, LIII (Márch, 1959), pp. 138-180.

"Constitutional Law in 1959-1960," $\underline{A} . \underline{P} . \underline{S} . \underline{R} .$, LV (March, 1961), pp. 112-135.

"The Flag Salute," Journal of National Education Association, XXXII (Dec., 1943), pp. 265-266.

"The Flag Salute Cases," The Bill of Rights Review, I (Summer, 1940), p. 9 . 
"Fourteenth Amendment -- Freedom of Press and Religion," Minnesota Law Review, XXVIII (Jan., 1944), pp. 133-135.

"Fourteenth Amendment -- Religious Liberty," Columbia Law Review, XI (June, 1940), pp. 1067-1071.

"Frankfurter and Stone," New Republic, CII (June 24, 1940), pp. 843-844.

"Freedom of Press and Religicn -- Ilcense Tax on Periodicals," Washington University Law Quarterly, XuvII (Feb., 1942), pp. $270-272$.

"Freedom of Religion, Press and Speech -- Licensing Ordinances," George Washington Law Review, XI (Dec., 1942), pp. 114116.

"Freedom of Religion -- Right to Impose a License Tax upon Dissemination of Religious Literature," Columbia Law Review, XIII (sept., 1942), pp. 1200-1203.

"Freedom of Religion, Speech, and Press, -- Nondiscriminatory License Fees for Sellers of Religious Books," Brooklyn Law Review, XII (Oct., 1942), pp. 71-74.

"Freedom of Speech -- Jehovah's Witnesses," Columbia Law Review, XLVI (May, 1946), pp. 457-460.

"Freedom of Speech, Press, and Religion -- Application of License Tax for Distribution of Religious Literature," Minnesota Law Review, XXVII (Dec., 1942), pp. 90-93.

"Freedom of Speech and of Religion -- Fourteenth Amendment," St. John's Law Review, XV (Nov., 1940), pp. 93-95.

Freund, Paul A. "The Supreme Court and Civil Liberties," Vanderbilt Law Review, IV (April, 1951), pp. 533-554.

Friedrich, Carl Jo "Rights, Liberties, Freedoms," University of Pennsylvania Law Review, XCI (Dec., 1942), pp. 312-320.

"The Gobitis Case in Retrospect," The Bill of Rights Review, I (Summer, 1941), pp. 267-268.

Green, John Raeburn, "Liberty Under the Fourteenth Amendment," Washington, University Law Quarterly, XXVII (Summer, 1942), pp. 497-562.

Harris, R.J. "Constitutional Law in 1948-1949," $\underline{\text { A.P.P.S.R. }}$. XIIV (March, 1950), pp. 23-46. 
"I'd Like to Talk to You a Minute," The New Yorker, XXxII (June, 16, 1956), pp. $72-75$.

Illinois Law Review of Northwestern University, XXXV (May, 1940), pp. $90-95$.

"Jehovah's Witnesses Cases Extend Religious Liberty," Christian Century, LXIII (Jan. 23, 1946), p. 100 .

"Jehovah's Witnesses Lose and Win," Christian Century, LXX (May 13, 1953), ip. 565.

"Jehovah's Witnesses Make Hate a Religion," Saturday Evening Post. (Sept. 14, 1940), pp. 18-20.

"Jehovah's Witnesses Win Again in the Supreme Court," Christian Century, LXXII (March 30, 1955), p. 2?.

Krock, Arthur. "Minorities' Rights in the Supreme Court," New York Times. June 11, 1942, p. 21.

Leek, John H. "Due Process: Fifth and Fourteenth Amendments," Political Science Quarterly, IX (June 1945), pp. 188-204.

"Licensing and Distribution of Religious Pamphlets," ChicagoKent Law Review, XX (Sept., 1942), pp. 349-354.

Luvaas, John L. "Freedom of Press, Freedom of Speech -- Rights of Religious Sects to Distribute Literature," Oregon Law Review, XXI (Dec., 1941), pp. 76-81.

Marion, Marty E. "Sects and Cults," Annals, CXXXII (Nov., 1960), pp. 125-134.

Masland, John W. "Treatment of the Conscientious objector Under the Selective Service Act of 1940," $\underline{\text { A. }} \underline{\underline{.}} \cdot \underline{\mathrm{S}} . \underline{\mathrm{R}}$., XXXVI (Aug., 1942), pp. 697-701.

Mason, Alpheus T. "The Core of Free Government, 1938-1940: Mr. Justice Stone and Preferred Freedoms," Yale Law Journal, LXV (April, 1956), pp. 597-628.

Miner, Julius H. "Religion and the Law," Chicago-Kent Law Review, XXI (March, 1943), pp. 156-180.

"Mob Action Against Sect on the Increase," Christian Century, LIX (oct., 7,1942 ), p. 3 .

Moley, Raymond, "The Boot is on the other Leg," Newsweek, IXX (June 29, 1942), p. 68. 
388

Mulder, John E. and Comisky Marvin. "Jehovah's Witnesses Moid Constitutional Law," The Bill of Rights Review, II (Summer, 1942), pp. 262-268.

Murphy, Jay. "Free Speech and the Interest in Local Law and Order," Journal of Public Law, I (Spring, 1952), pp. 40-70.

New York Times, Sept. 21, 1942.

= Nov. 29. 1942.

, Mar. 9, 1943.

, Mar. 11, 1943.

, Aug. 7, 1950.

, July 24, 1953.

, July 25, 1953.

New York Times Magazine, Aug. 1, 1954.

"Ominous Decision," Time, $\operatorname{xxxIX~(June~22,~1942),~pp.~55-56.~}$

Pressley, Harold Jr. "Expanding Civil Liberties in the Supreme Court," Texas Law Review, XXII (Feb., 1944), pp. 230235.

"Religious Freedom -- Constitutionality of State Statutes Prohibiting Solicitation for Religious Causes Without the Approval of an Administrative Official," Iowa Law Review, XXVI (Nov., 1940), pp. 126-130.

Rotnem, Victor W., and Folsom, F.G. Jr. "Recent Restrictions upon Religious Liberty," A. pp. 1053-1068.

Rowland, S. Jr. "Armageddon," Nation, CLXXXII (Nov., 24, 1956), p. 464 .

"State Licensing of the Distribution of Literature and Freedom of the Press and Religion," Fordham Law Review, XI (Nov., 1942), po. 304-310.

"State Regulation of Street Processions," Bill of Rights Review, I (Spring, 1941), pp. 232-235.

"States' Police Power -- Licensing Limitations on Freedom of Religion," Virginia Law Review, XXIX (Dec., 1942), pp. $339-341$. 
389

Stroup, H.H. "Review of the Jehovah's Witnesses," Christian Century, IXII (June 20, 1945), p. 734 .

Use of Taxation and Licensing in the Suppression of Freedom of Religion and the Press," Yale Law Journal, III (Dec., 1942), pp. 168-175.

Vose, Clement E. "Litigation as a Form of Pressure Group Activity," Annals, CIXX (Sept., 1958), pp. 20-31.

Waite, Edward F. "The Debt of Constitutional Law to Jehovah's Witnesses," Minnesota Law Review, XXV III (March, 1944), pp. 209-246.

Warren, Charles. "The New 'Liberty' Under the Fourteenth Amenoment," Harvard Law Review, XXXVII (Feb., 1926), pp. $431-463$.

Washington Times Herald, March 13, 1945.

Wilcher, Denny. "Shall the C.P.S. Camp Continue?" Christian Century, IIX (Dec., 16, 1942), pp. 1556-1559.

"Witnesses to be Rehired," Business Week. (April 10, 1943), p. 99 .

Wright, Herbert. "Religious Iiberty Under the Constitution of the United States," Virginia Law Review, XXVII (Nov., 1940), pp. 75-87.

Books

Bachrach, Peter. Problems in Freedom. Pennsylvania: Telegraph Press, 1954.

Beaney, William M. "The Supreme Court and Civil Liberties," American Government Annual, 1961-1962. New York: Holt, Rinehart and Winston Inc., 1961.

Berger, Morroe. Equality By Statutes: Legal Controls over Group Discrimination. New York: Columbia Univ. Press, 1952.

Blackstone, William. Commentaries on the Laws of England. New York: Harper and Bros., 1850.

Bontencou, Eleanor (ed.). Freedom in the Balance: Opinions of Judge Henry W. Edgerton Relating to Civil Liberties. Ithaca: Corneil Univ. Press, 1960.

Braden, Charles Samuel. These Also Belleve: A Study of Modern American Cults and Minority Religlous Movements. New York: Macmilian Co., 1949). 
390

Brennan, William J. Jr. The Bill of Rights and the States. New York: Fund for the Republic Publication, 1961.

Carr, Robert K. Federal Protection of Civil Rights: Quest for a Sword. Ithaca: CornelI Univ. Press, 1957.

Castberg, Frede. Freedom of Speech in the West, A Comparative Study of Public Law in France The United States and Germany. Os10: OsIo UnIV. Press, 1960.

Chafee, Zechariah Jr. Free Speech in the United States. Cambridge: Harvard Univ. Press, I942.

Clancy, William et. al. Religion and American Society. New York: Fund for the Republic Publication, 1959.

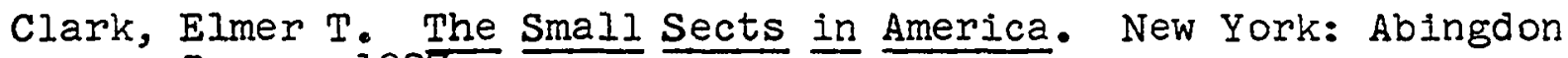
Press, 1937.

Cooley, Thomas M. Constitutional Limitations. Boston: Little, Brown, and Co., 1927.

Corwin, Edward S. The Constitution and What it Means Today. Princeton: Princeton Univ. Press, 1958.

The Constitution of the United States of America, Revised and Annotated. D.C.G Overnment Printing Of'ice, 1953.

Clairmont Colleges, Revolution Limited. California:

The Twilight of the Supreme Court: A History of our" ConstitutionaI Theory. New Haven: YaIe Univ. Press, 1934.

Curtis, Charles P. Jr. Lions Under the Throne. Boston: Houghton Mifflin, Ig47.

Cushman, Robert E. Leading Constitutional Decisions. New York: Appleton-Century-Crof'ts Inc., 1960.

Defending and Establishing the Good News. Brooklyn: Watchtower BIble and Tract Society, 1950 .

Douglas, William 0. An Almanac of Liberty. New York: Doubleday and Co., 1954 .

- The Right of the People, New York: Doubleday and Co.', 1958.

, We the Judges: Studies in Indian Constitutional Law' from Marshali to Mukherjea. New York: Doubleday and 
Co., 1956.

Duggan, Joseph C. The Legislative and Statutory Development of the Federal concept of Conscription for Military Service. D.C. Catholic Univ. of American press, 1946.

Dumbauld, Edward. The Bill of Rights and What it Means Today. Norman: Univ. Of OkIahoma Press, I957.

Evander, Willis Hugh. Constitutional Law of the United States. Bloomington: Princioia Press, 1936 .

The Federalist. New York: Random House.

Fellman, David. The Limits of Freedom. New Brunswick: Rutgers Univ. Press, 1959.

Ferm, Verilius (ed.). Religion in the Twentieth Century. New York: Philosophical Library, I948.

Fitzpatrick, Edward A. Universal Military Training. New York McGraw-Hill Book Co., 1945.

Fraenkel, Osgood K. The Supreme Court and Civil Liberties. New York: Oceana Publications Inc., 1960.

Frankfurter, Felix. Law and Politics: Occasional Papers of Felix Frankfurter, 1913-1938. Edited by Archibald Fiacleish, and S.F. Prichard Jr. New York: Harcourt Brace and Co., 1939.

Freund, Paul A. et. al. Constitutional Law: Cases and Other Problems. 2 vols. Boston: Little, Brown and Co., I961.

Gordis, Robert et. al. Religion and the Schools. New York: Fund for the Repubilc Publication, 1961.

Gray, Harold Studiey, Character "Bad," The Story of a Conscientious objector. New Tork: Harper and Bros., 1934.

Hall, Verna M. Christian History of the Constitution of the United states. San Francisco: Anerican Christian Constitution Press, 1943.

Handlin, Oscar and Mary. The Dimensions of Liberty. Cambridge: Harvard Univ. Press: I961.

Herberg, Will. Protestant Catholic Jew: An Essay in American Religious Soclology. New York: Doubleday and Co., 1955.

Holcombe, Arthur N. Our More Perfect Union. Cambridge: Harvard Univ. Press, 1950. 
Holy Bible.

Howe, Mark Dewolf. Cases on Church and State in the United States. Cambridge: Harvard Univ. Press, 1952.

James, Joseph B. The Framing of the Fourteenth Amendment: Urbana: Univ. of IIIinois Press, 1956.

Johnsen, Julia, Peacetime Conscription. New York: H.W. Wilson Co., 1945.

Kelly, Alfred H., and Harbison, Winfred A. The American Constitution, Its Origins and Development. New York: W.W. Norton and Co., 1955.

Konvitz, Milton R. Fundamental Liberties of a Free People. Ithaca: Cornell Univ. Press, 1957. and Rossiter Clinton (
Ithaca: Cornell Univ. Press.

Lamont, Corliss, Freedom is as Freedom Does: Civil Liberties Today. New York: Horizon Press, 1956

Macarthur, Kathleen. The Bible and Human Rights. New York: The Women's Press, 1948.

Macmillan, A.H. Faith on the March. Englewood Cliffs: PrenticeHail Inc., 1957.

Manwaring, David R. Render Unto Caesar. Chicago: Univ. of Chicago Press, 1962.

Maritain, Jicques. The Rights of Man and Natural Law. Glassgow: Glasgow Univ. Press, 1958.

Marx, Herbert L. Jr. Universal Conscription for Essential Service. New York: H.W. Wilson Co., 1951.

Mason, Alpheus T. Harlan Fiske Stone: Piliar of the Law. New York: Viking Press, 1956.'

The Supreme Court from Taft to Warren. Baton Rouge: Lou'isiana State Univ. Press, T958.

and Beaney, William M. The Supreme Court in a Free Society. Englewood Cliffs: Prentice-Hall Inc., 1959.

McCune, Wesley. The Nine Young Men. New York: Harper and Bros. 1947. 
393

Meiklejohn, Alexander. Free Speech and its Relation to SelfGovernment. New York: Harper and Bros:; 1948.

The Constitution and the Supreme Court. New York:

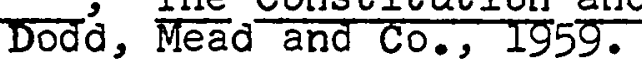

Mendelson, Wallace. Justices Black and Frankfurter: Conflict in the Court. Chicago: Univ, of Chicago Press, 1961.

Miller, William Lee, et. al. Religion and the Free Society. New York: Fund for the Repubilc Publication, 1958.

Moehlman, Henry Conrad. The Wall of Separation Between Church 'and State. Boston: Beacon Press, 1951.

Moss, James Alfred. The Flag of Cur United States. Chicago: Rand MeNally and Co., 1938 .

Mott, Rodney L. Due Process of Law. Indianapolis: Bobbs-Merrill Co., 1926.

Parsons, Wifrid. The First Freedom, Consideration on Church and State in the Jnited States. New York: J.J. LIttle and Ives co., 1948 .

Phillips, Harlan B. Felix Frankfurter Reminisces. New York: Reynal and Co., 1960 .

Pike, Royston. Jehovah's Witnesses: Who They Are, What They Teach, what They Do. New York: Philosophical Library, 1954.

Pritchett, C. Herman. The American Constitution. New York: McGraw-Hill Inc. 1959.

The Roosevelt Court: Study in Judicial Politics and values. New York: Macmillañ Co., 1948.

Quaife, Milo Milton. The Flag of the United States, New York: Grosset and Dunlap, 1942 .

Quidam, Roger D. The Doctrine of Jehovah's Witnesses. New York: Philosophical Library, 1959 .

Repoy, Allison, Civil Rights in the United States. New York: Central Book Co., 1951.

Rottschaefer, Henry. Handbook of American ConstitutionaI Law. St. Paul: West Publishing Co., 1939.

Rutherford, Joseph $T$. Government. Brooklyn: Watchtower Bible and Tract Society, 1928. 


\section{4}

Schneider, Herbert wallace. Religion in Twentieth Century America. Cambridge: Harvard Univ. Press, 1952.

Schwartz, Bernard. The Supreme Court: Constitutional Revolution in Retrospect. New York: The Ronald Press Co., 1957.

Sibley, Mulford Q., and Jacob, Philip E. Conscription of Conscience. Ithaca: Cornell Univ. Press, 1952.

Smith, Chard Powers. Yankees and God. New York: Hermitage House, 1954.

Stokes, Anson Phelps. Church and State in the United States. New York: Harper and Bros., 1950.

Story, Joseph. Commentaries on the Constitution. Boston: Little, Brown and Co., Ig27.

Sweet, William Warren. The Story of Religion in America. New York: Harper and Bros., 1939.

Swisher, Carl B. American Constitutional Deveiopment. Cambriage: Houghton Miffilin Co., 1954.

- The Supreme Court in Modern Role. Washington Square: New York Univ. Press, 1958.

Thomas, Helen Shirley. Felix Frankfurter, Scholar on the Bench. Baltimore: Johns Hopkins Press, 1960.

Tresolini, Rocco J. American Constitutional Law. New York: The Macmilian Co., 1959.

Weaver, Samuel P. Constitutional Law and its Administration. Chicago: Callaghan and Co., I946.

Wechsler, Herbert, Principles, Politics and Fundamental Law. Cambridge: Harvard UnIv. Press, 1961.

wood, Virginia. Due Process of Law 1932-1949, The Supreme Court's Use of a constitutional Tool. Baton Kouge: Lougsiana State Univ. Press, 1951 .

\section{Reports}

National Service Board for Religious Objectors. Statements of Religious Bodies on the Conscientious objector. D.C. By the N.S.B.R.O., 1957.

Report of the President's Committee on Civil Rights. To Secure These Rights. D.C.Government Printing Office, I947. 
395

U.S. Senate, Committee on Education and Labor, Violations of

Free Speech and Rights of Labor, Res. 266, Part II,

74 th cong., 1937 .

Yearbook of American Churches, 1943.

1960. 